UNIVERSIDADE DE BRASÍLIA - UnB INSTITUTO DE GEOCIÊNCIAS - IG

PROGRAMA DE PÓS-GRADUAÇÃO EM GEOLOGIA

METALOGÊNESE DO DEPÓSITO DE ESTANHO LIBERDADE, CAMPO NOVO DE RONDÔNIA - RO

DISSERTAÇÃO DE MESTRADO No 345

PAULO SÉRGIO MENDES DOS SANTOS JÚNIOR

BRASÍLIA - DF 


\section{METALOGÊNESE DO DEPÓSITO DE ESTANHO LIBERDADE, CAMPO NOVO DE RONDÔNIA - RO}

\section{PAULO SÉRGIO MENDES DOS SANTOS JÚNIOR}

Dissertação apresentada ao Programa de Pós-Graduação em Geologia do Instituto de Geociências, Universidade de Brasília, como requisito para obtenção do título de Mestre em Geociências, área de concentração Geologia Econômica.

\section{Orientador}

Prof. Dr. Valmir da Silva Souza

Banca Examinadora

Prof. Dr. Valmir da Silva Souza (IG-UnB)

Prof. Dr. Márcia Abraão Moura (IG-UnB) 
A Deus, aos meus pais Natanilde Carvalho dos Santos e Paulo Sérgio Mendes dos Santos, a minha esposa Estela Brito de Souza, a minha família e aos meus verdadeiros amigos. 
Primeiramente agradeço a Deus por proporcionar grandes vitórias em minha vida, me fortalecendo a cada dia através de seu plano espiritual e me fornecendo toda a força necessária para a execução deste trabalho.

Agradeço aos meus pais, Paulo Sérgio e Natanilde Carvalho, por toda força e ajuda nessa etapa da minha vida, pelo esforço em me dá uma excelente educação e por me fornecer todo o amor, carinho, conforto e aconchego em todos os momentos da minha vida, mesmo de longe. À minha avó Guiomar Mendes, à minha tia Maria de Fátima e as minhas irmãs Patrícia Carolina e Tatiana Cristina pela credibilidade, apoio e por toda força e ajuda necessárias para a conquista de mais essa vitória em minha vida.

A minha esposa Estela Brito por todo o apoio, amor, dedicação e incentivo para que eu terminasse mais essa etapa da minha vida.

Gostaria de agradecer às seguintes instituições e pessoas que tornaram tecnicamente possível a realização deste trabalho:

Ao Programa de Pós-graduação em Geologia da Faculdade de Geologia do Instituto de Geociências da UnB por me proporcionar a oportunidade de adquirir o título de mestre em uma das melhores instituições públicas de ensino do Brasil.

Ao CNPq e a FAPEAM pelo financiamento do projeto de pesquisa e a CAPES pela bolsa de estudos.

A empresa Metalmig Mineração por concordar em liberar a área do depósito Liberdade para o estudo, além de fornecer todo o apoio logístico e técnico nos períodos de campo. Agradeço aos geólogos Wanderley Vital e Aloísio Souza, ao engenheiro de minas Severino Souza, ao geógrafo Renato Plautino, ao encarregado de campo Leônidas Rodrigues e aos auxiliares de campo pelo apoio nas campanhas de campo.

Ao professor Valmir Souza pela valorosa orientação durante todas as etapas do trabalho. Ao professor Nilson Botelho pelo valoroso apoio durante todas as etapas do trabalho. Agradeço, também, a todos os professores que direta ou indiretamente me ajudaram e repassaram com ética e competência um pouco de suas experiências durante a minha permanência no Programa de Pós-graduação em Geologia da UnB.

Por fim, agradeço aos colegas e amigos que sempre me proporcionaram momentos de imensa descontração e alegria, sempre acrescentando algo positivo em minha vida. Agradeço pelos momentos de alegria, de tristeza e principalmente de superação. Aos amigos Fábio Makino, Fabrício Daniel e Edmundo Wallace, um agradecimento especial por tudo que fizeram por mim em Brasília, participando diretamente dessa etapa da minha vida. Aos amigos Kleyver Lenno, Kléber "Índio" \& Allan Pantoja também um agradecimento especial pela grande ajuda. Agradecimentos especiais também a Ana Paula Ribeiro, Diogo Orphão, Leila Braga e a todos os aqui não citados. Serei sempre grato a todos por marcarem minha vida com gestos tão verdadeiros e fraternos.

Muito Obrigado! 
"As conquistas são adquiridas através de vitórias, mas as vitórias são consequências de atos corajosos..."

\section{Eduardo Araújo}




\section{RESUMO}

O Estado de Rondônia aloja várias suítes graníticas tipo A, alojadas durante sucessivos episódios magmáticos entre 1606 e 974 Ma. Tais suítes graníticas formam a Província Estanífera de Rondônia, cujas mais expressivas concentrações metálicas ( $\mathrm{Sn}, \mathrm{W}, \mathrm{Nb}, \mathrm{Ta}$ ), além de $\mathrm{F}$ e gemas, estão associadas aos três últimos episódios magmáticos, ocorridos entre 1314 e 974 Ma e representados pelas unidades regionais conhecidas por Suíte Intrusiva São Lourenço-Caripunas (1314-1309 Ma), Suíte Intrusiva Santa Clara (1082-1074 Ma) e Suíte Intrusiva Rondônia (995-974 Ma). Na parte central da Suíte Intrusiva Alto Candeias (1358-1320 Ma) ocorrem depósitos de estanho, entre os quais destaca-se o depósito Liberdade, objeto deste estudo, que produziu entre os anos de 2005 e 2009 cerca de 1000 toneladas de cassiterita. Esses depósitos têm sido relacionados às manifestações hidrotermais tardi a pós-magmáticas vinculadas à Suíte Intrusiva Rondônia. Entretanto, dados petrográficos, geoquímicos e geocronológicos ( $\mathrm{U}-\mathrm{Pb}$ e $\mathrm{Ar}-\mathrm{Ar}$ ) apresentados nesse estudo não suportam tal proposta.

Os tipos petrográficos identificados na parte centro-sul da Suíte Intrusiva Alto Candeias, no depósito de estanho Liberdade, são representados por biotita-hornblenda granito rapakivi, hornblenda-biotita granito inequigranular médio e biotita granito inequigranular fino, sendo que esse último tipo foi encontrado apenas na frente de lavra do depósito. Esses tipos petrográficos apresentaram idade U-Pb entre 1357-1336 Ma, caráter subalcalino, metaluminoso a peraluminoso e moderado a alto grau de fracionamento dos ETR leves em relação aos pesados, características geoquímicas compatíveis com granitos do tipo A alojados em ambiente intraplaca tardi a pós-colisional. Os dados de Sm-Nd revelam assinatura isotópica com valores de $\varepsilon_{\mathrm{Nd}}(\mathrm{t})$ próximos a zero (+0.88 a -0.94) e idade modelo ( $\left.\mathrm{T}_{\mathrm{DM}}\right)$ entre 1.59 e $1.76 \mathrm{Ga}$, evidenciando que a evolução magmática ocorreu a partir da fusão parcial de crosta continental antiga (Paleoproterozóica), em processo que envolveu mistura entre magmas crustais e mantélicos. Tais informações petrológicas estão em conformidade com os dados já conhecidos sobre a Suíte Intrusiva Alto Candeias (Bettencourt et al. 1995, Bettencourt et al. 1997, Bettencourt et al. 1999a, Santos et al. 2000, Santos et al. 2002, Santos 2004, Scandolara 2006, Santos et al. 2008, Queiroz 2009, Bettencourt et al. 2010, Geraldes e Nogueira 2013). Por outro lado, investigações geocronológicas ${ }^{40} \mathrm{Ar}-$

${ }^{39} \mathrm{Ar}$ sobre a mineralização estanífera associada a veios e greisens presentes no depósito Liberdade revelaram a idade platô ${ }^{40} \mathrm{Ar}-{ }^{39} \mathrm{Ar}$ de $1308 \mathrm{Ma}$, interpretada como resfriamento do sistema hidrotermal responsável pela mineralização de estanho. Adicionalmente, estudos isotópicos $\delta^{18} \mathrm{O}$ e $\delta \mathrm{D}$ revelaram que a temperatura de cristalização da cassiterita é de $430^{\circ}$ a $445^{\circ} \mathrm{C}$, cujos fluidos possuem assinatura isotópica relacionadas a interação entre fluidos magmáticos e meteóricos, com pouco ou nenhum aporte de fluidos metamórficos. O estudo de química mineral revelou que a cassiterita no depósito Liberdade exibe zoneamento caracterizado pela alternância de faixas de cores claras (ricas em $\mathrm{SnO}_{2}$ ) e escuras (ricas em $\mathrm{FeO}_{\text {(total) }}, \mathrm{TiO}_{2}, \mathrm{Nb}_{2} \mathrm{O}_{5}$ e $\mathrm{WO}_{3}$ ).

Em acréscimo, é importante ressaltar que as mineralizações estaníferas em Rondônia estão associadas às fases hidrotermais derivadas dos episódios magmáticos subvulcânicos finais de sistemas rapakivíticos. Tal situação não foi identificada na parte centro-sul da Suíte Intrusiva Alto Candeias. Adicionalmente, o biotita granito inequigranular fino, que hospeda a mineralização no depósito Liberdade, apresenta idade U-Pb de $1336 \pm$ $24 \mathrm{Ma}$, enquanto que a fase hidrotermal responsável pela mineralização estanífera apresenta idade ${ }^{40} \mathrm{Ar}^{39}{ }^{30} \mathrm{Ar}$ 1308 +5 Ma. Há uma lacuna de tempo de aproximadamente 30 Ma entre as idades de cristalização U-Pb e de resfriamento ${ }^{40} \mathrm{Ar}-{ }^{39} \mathrm{Ar}$, tempo que pode ser considerado demasiadamente elevado e conduz a não interpretar a fase hidrotermal como derivada ou exsolvida da Suíte Intrusiva Alto Candeias. Além do mais, o espectro de idade Ar (Idade Plateau) indica ausência de perturbações térmicas mais jovens e desvincula a mineralização de estanho do plutonismo granítico relacionado à Suíte Intrusiva Rondônia, na região. Tais contrastes conduzem a seguinte conclusão: a fase hidrotermal responsável pela mineralização de estanho não está associada aos processos tardi a pós-magmáticos das rochas encaixantes da Suíte Intrusiva Alto Candeias e tampouco à Suíte Intrusiva Rondônia. Ela está provavelmente associada com fase magmática intrusiva e não aflorante na parte central do batólito Alto Candeias, que pode ser cronologicamente correlacionada ao sistema magmático regional especializado em estanho chamado Suíte Intrusiva São Lourenço-Caripunas (1314-1309 Ma).

Palavras chaves: Província Estanífera de Rondônia, batólito Alto Candeias, mineralização de estanho, geocronologia U-Pb e Ar-Ar 


\section{Abstract}

The Rondônia state lodges several type A granitic suites placed during successive magmatic episodes between 1606 and $974 \mathrm{Ma}$. Such granitic suites form the Rondônia tin Province, where the most expressive metallic concentrations ( $\mathrm{Sn}, \mathrm{W}, \mathrm{Nb}, \mathrm{Ta}$ ) besides $\mathrm{F}$ and gemstones, are associated to the three last magmatic episodes that took place between 1314 and $974 \mathrm{Ma}$ and are represented by the regional units known as São Lorenço-Caripunas Intrusive Suite (1314-1309 Ma), Santa Clara Intrusive Suite (1082-1074 Ma) and Rondônia Intrusive Suite (995-974 Ma). In the central part of the Alto Candeias Intrusive Suite (1358-1320 Ma) there occur tin deposits, where one can highlight the Liberdade deposit, which is the object of this study, and has produced about 1000 tonnes of cassiterite between 2005 and 2009. These deposits have been related to tardi to post-magmatic hydrothermal manifestations associated to Rondônia Intrusive Suite. However, petrographic, geochemical and geochronological data (U-Pb and $\mathrm{Ar}-\mathrm{Ar}$ ) presented in this study do not support such proposal.

The petrographic data identified in the center-south part of the Alto Candeias Intrusive Suite, in the Liberdade tin deposit, are represented by biotite-hornblend Rapakivi granite, medium grained non-equigranular hornblend-biotite granite and fine non-equigranular biotite granite, the latter one being found only at the exploitation fronts of the deposit. These petrographic types show U-Pb age between 1357- $1336 \mathrm{Ma}$, a sub alkaline character, metalluminous to peralluminous and a moderate fractioning degree of the light REE in relation to the heavy ones, geochemical characteristics compatible to type A granites lodged in tardi to postcollisional intraplate environment. The $\mathrm{Sm}-\mathrm{Nd}$ data reveal an isotopic signature with $\varepsilon \mathrm{Nd}(\mathrm{t})$ values close to zero (+0.88 to -0.94$)$ and model age (TDM) between 1.59 and $1.76 \mathrm{Ga}$, evidentiating that the magmatic evolution occurred from the partial melting of the ancient continental crust (Paleoproterozoic), as a process that involved a mix of crustal and mantellic magmas. Such petrological information are in accordance to the already known data about the Alto das Candeias Intrusive Suite (Bettencourt et al. 1995, Bettencourt et al. 1997, Bettencourt et al. 1999a, Santos et al. 2000, Santos et al. 2002, Santos 2004, Scandolara 2006, Santos et al. 2008, Queiroz 2009, Bettencourt et al. 2010, Geraldes e Nogueira 2013). On the other hand, ${ }^{40} \mathrm{Ar}-{ }^{39} \mathrm{Ar}$ geochronological investigations on the tin mineralization associated to veins and greisens occurring in the Liberdade deposit revealed a ${ }^{40} \mathrm{Ar}-{ }^{39} \mathrm{Ar}$ age of $1308 \mathrm{Ma}$, interpreted as a cooling of the hidrothermal system responsible for the tin mineralization. In addition, $\delta^{18} \mathrm{O}$ e $\delta \mathrm{D}$ isotopic studies revealed that the crystallization temperature of the cassiterite is that of $430^{\circ}$ a $445^{\circ} \mathrm{C}$, with fluids have isotopic signature related to interaction between magmatic and meteoric fluids, with little or no input of metamorphic fluids. The study of the mineral chemistry revealed that the tin in the Liberdade deposit shows a zoning featured by the alternation of light colored layers $\left(\mathrm{SnO}_{2}\right.$ rich) and dark layers $\left(\mathrm{FeO}_{\text {(total }}, \mathrm{TiO}_{2}, \mathrm{Nb}_{2} \mathrm{O}_{5}\right.$ and $\mathrm{WO}_{3}$ rich).

In addition, it is important to highlight that the tin mineralizations in Rondonia are associated to hydrothermal phases derivated from final subvolcanic magmatic episodes of the Rapakivi system. Such situation was not identified in the center-south part of the Alto Candeias Intrusive suite. Additionally, the fine nonequigranular biotite granite that hosts the mineralization in the Liberdade deposit shows a U-Pb age of $1336 \pm 24$ $\mathrm{Ma}$, while the hydrothermal phase responsible for the Sn mineralization shows a ${ }^{40} \mathrm{Ar}-{ }^{39} \mathrm{Ar}$ age of $1308 \pm 5 \mathrm{Ma}$. There is a time gap of approximately $30 \mathrm{Ma}$ between the U-Pb crystallization and the ${ }^{40} \mathrm{Ar}^{39} \mathrm{Ar}$ cooling ages, which might be considered very high and leads to not interpret the hydrothermal phase as being derivate or exolved from the Alto Candeias Intrusive Suite. Besides, the Ar age spectrum (Plateau age) indicates the absence of younger thermal disturbances and unlinks the Sn mineralization from granitic plutonism related to the Rondônia Intrusive suite, in the region. Such contrasts lead to the following conclusion: the thermal phase responsible for the Sn mineralization is not associated to the tardi to post magmatic processes of the Alto Candeias hosting rocks and neither to the Rondônia Intrusive suite. It is probably associated to non-outcropping Intrusive magmatic phase in the central part of the Alto Candeias batholith which might be chronologically correlated to the regional magmatic system specialized in tin called São Lourenço-Caripunas Intrusive suite 1314-1309 Ma).

Keywords: Rondonia tin province, Alto Candeias batholit, tin mineralization, $\mathrm{U}-\mathrm{Pb}$ and $\mathrm{Ar}-\mathrm{Ar}$ geochronology. 


\section{SUMÁRIO}

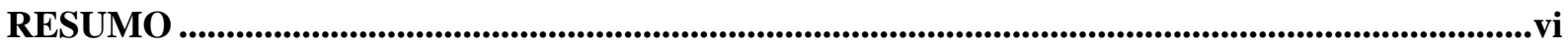

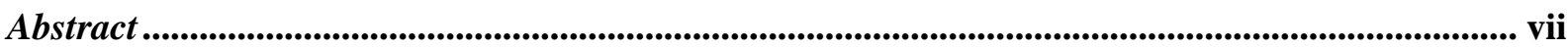

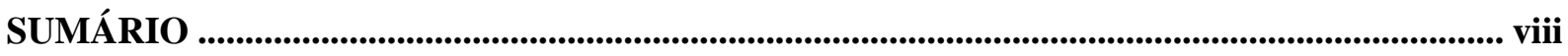

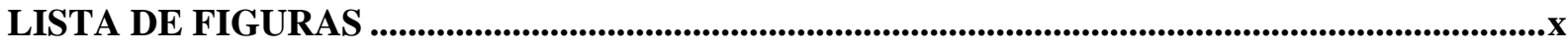

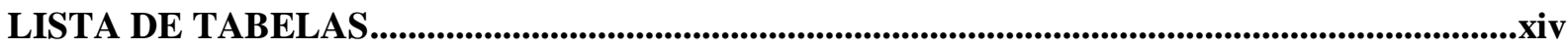

\section{CAPÍtULO 1}

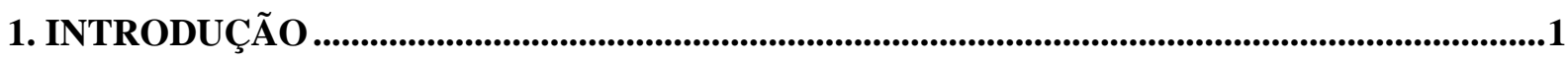

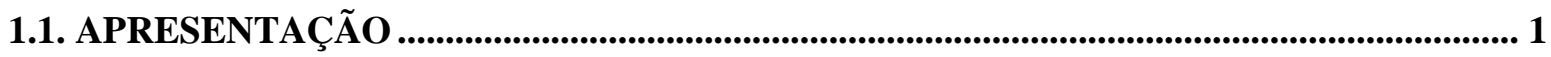

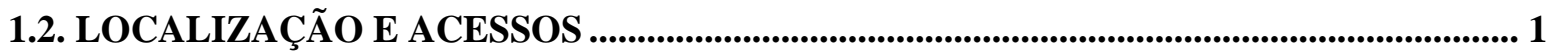

1.3. PROBLEMÁTICA E JUSTIFICATIVA DA PESQUISA ............................................... 1

1.4. OBJETIVOS ................................................................................................................................................... 2

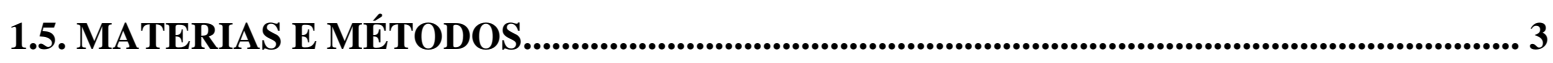

1.6. SÍNTESE DO CONHECIMENTO GEOLÓGICO REGIONAL ....................................... 5

1.6.1. Contexto Geotectônico..............................................................................................................5

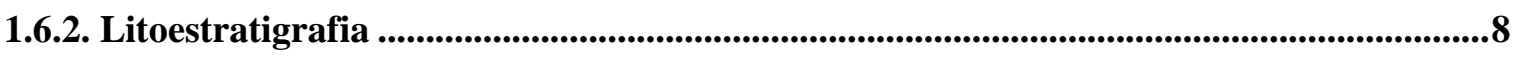

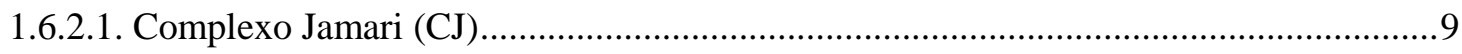

1.6.2.2. Suíte Intrusiva Serra da Providência (SISP) ..................................................................10

1.6.2.3. Suíte Intrusiva Rio Crespo (SIRC) .............................................................................

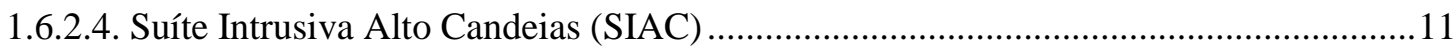

1.6.2.5. Formação Nova Floresta (FNF) ……………............................................................12

1.6.2.6. Formação Palmeiral (FP) ……………….................................................................. 12

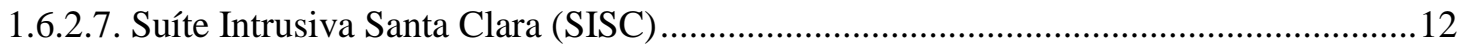

1.6.2.8. Suíte Intrusiva Rondônia (SIR) ou Granitos Jovens de Rondônia (Younger Granites)13

1.6.2.9. Coberturas Cenozóicas (CC) .................................................................................. 13

\section{CAPÍtULOO 2}

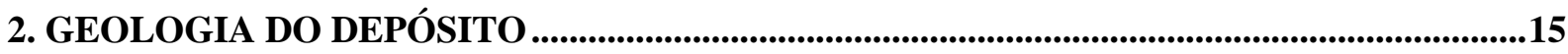

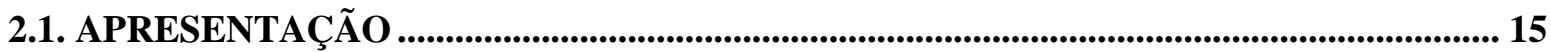

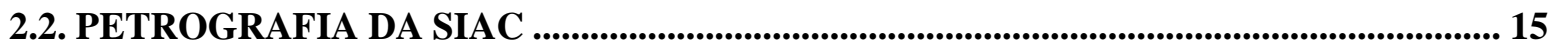

2.2.1. Biotita-hornblenda granito rapakivi .......................................................................................15

2.2.2. Hornblenda-biotita granito inequigranular médio ................................................................19

2.2.3. Biotita granito inequigranular fino .....................................................................................20

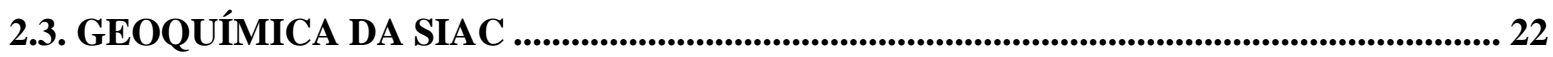

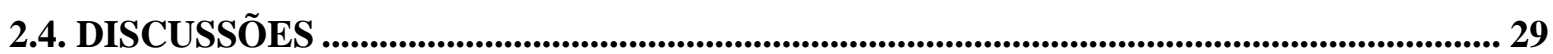

\section{CAPÍtULO 3}


3. SISTEMA MINERALIZADO \& COMPOSIÇÃO QUÍMICA DA CASSITERITA NO DEPÓSITO DE ESTANHO LIBERDADE ......................................................................................37

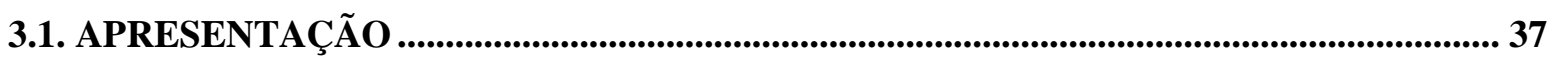

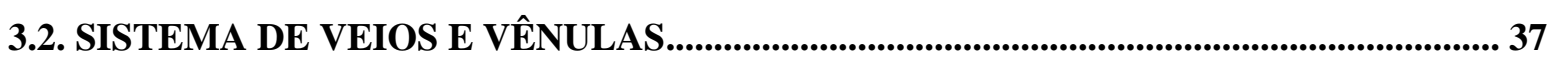

3.3. GREISENS DO DEPÓSITO DE ESTANHO LIBERDADE.................................................. 38

3.3.1. Quartzo-muscovita greisen com fluorita.......................................................................38

3.4. SEDIMENTOS ALUVIAIS E COLUVIAIS MINERALIZADOS ....................................... 43

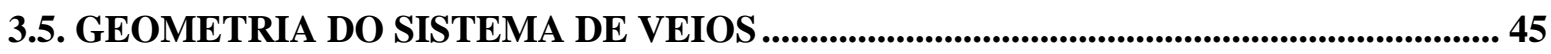

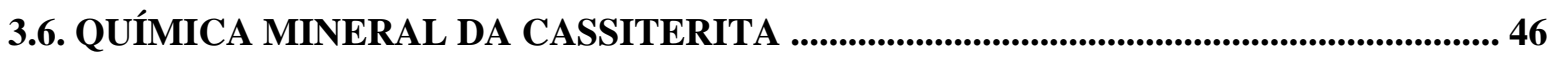

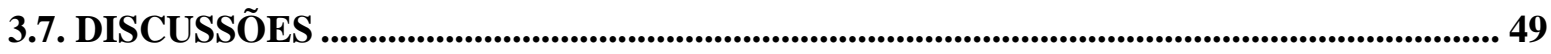

\section{CAPÍTULO 4}

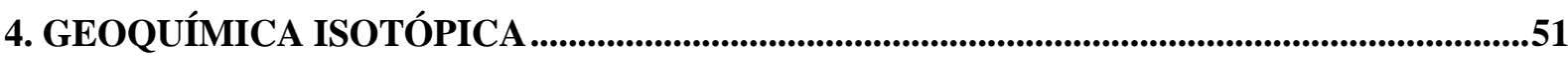

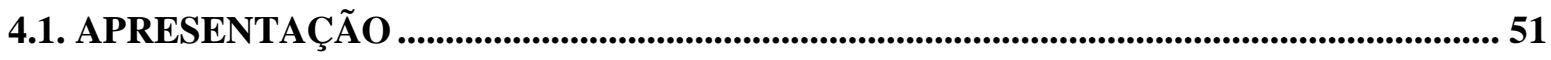

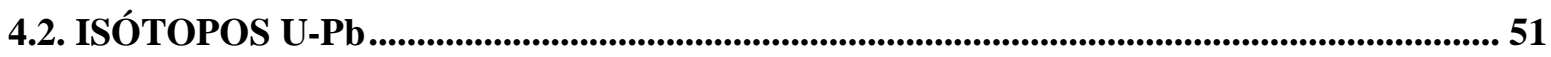

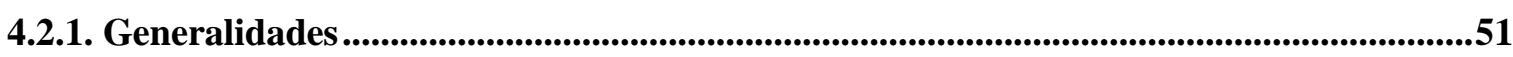

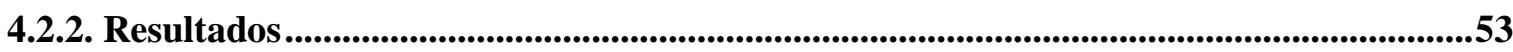

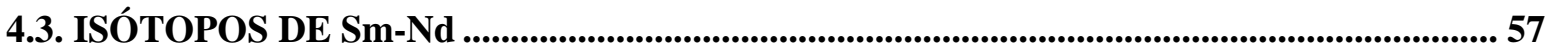

4.3.1. Generalidades............................................................................................................................................57

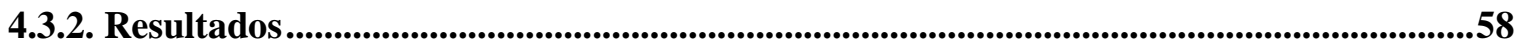

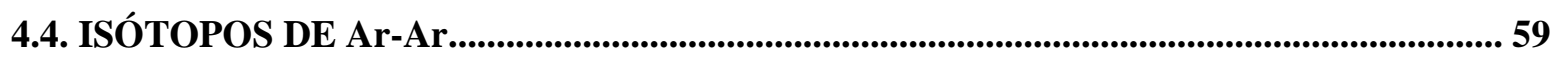

4.4.1. Generalidades................................................................................................................................................59

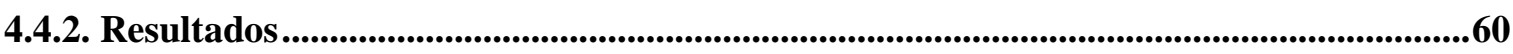

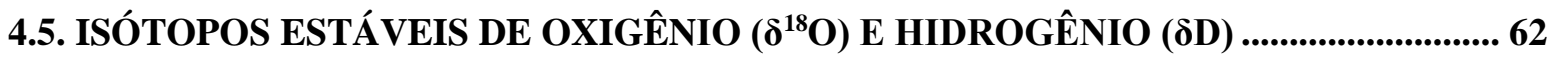

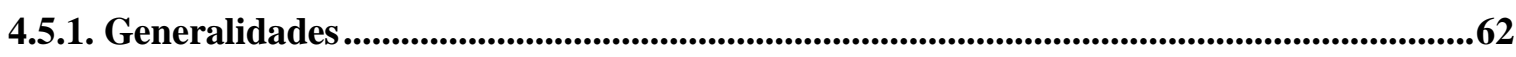

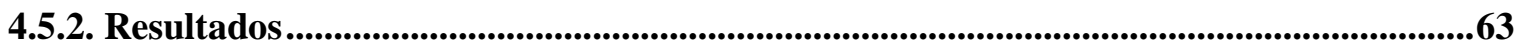

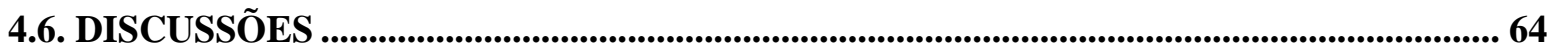

CAPÍTULO 5

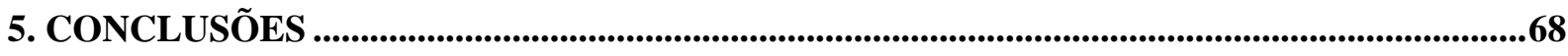

CAPÍTULO 6

6. REFERÊNCIAS BIBLIOGRÁFICAS ......................................................................................72

ANEXOS

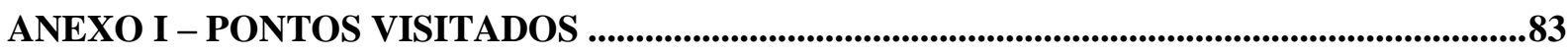

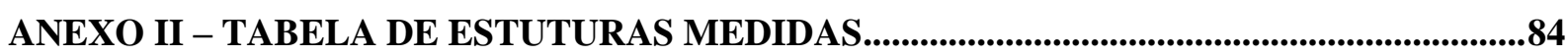

ANEXO III - TABELA DE ANÁLISE DE QUÍMICA MINERAL DA CASSITERITA DOS

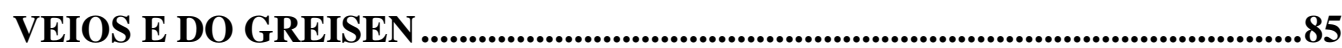




\section{LISTA DE FIGURAS}

\section{CAPÍtULOO 1}

Figura 1.1. Mapa de localização do depósito de estanho Liberdade.

Figura 1.2. Principais propostas de compartimentação geocronológica para o Cráton Amazônico: A) proposta de Almeida et al. (1977); B) proposta de Tassinari e Macambira (1999), modificado em Tassinari e Macambira (2004); C) proposta de Santos et al. (2000), modificado em Santos et al. (2008); D) proposta de Hasui et al. (1984). O retângulo negro é a área da Província Estanífera de Rondônia.

Figura 1.3. Mapa de Terrenos Tectono-Estratigráficos do Estado de Rondônia, segundo Scandolara et al. (1999).

Figura 1.4. Mapa Geológico da porção centro-sul da Província Estanífera de Rondônia, segundo Quadros (2007), modificado de Adamy (2010).

\section{CAPÍTULO 2}

Figura 2.1. Mapa e perfil geológico da região do depósito de estanho Liberdade. O quadrado amarelo indica a área do depósito de estanho Liberdade.

Figura 2.2. Fotografias de duas fácies de granitos da SIAC mapeados dentro da área do depósito de estanho Liberdade: A) biotita-hornblenda granito rapakivi; B) biotita-hornblenda granito levemente greisenizado; C) hornblenda-biotita granito inequigranular médio; D) contato entre o biotitahonblenda granito rapakivi saprolitizado e o biotita granito fino da frente de lavra.

Figura 2.3. Diagrama QAP mostrando as amostras das três fácies graníticos da SIAC mapeados no depósito de estanho Liberdade, modificado de Streckeisen (1976, apud Le Maitre 1989).

Figura 2.4. Aspectos texturais do biotita-hornblenda granito rapakivi (piterlitos), ressaltando sua granulação e os cristais de feldspatos zonados de tamanho centimétrico.

Figura 2.5. Fotomicrografias do biotita-hornblenda granito rapakivi: A) cristal de microclínio exibindo micro inclusões de quartzo e, cristal de oligoclásio exibindo feições pertíticas; B) cristal de oligoclásio exibindo feições granofíricas; C) cristal de hornblenda parcialmente cloritizada e com exsoluções de oxi-hidróxidos de ferro; D e E) reequilíbrio da hornblenda formando grunnerita; F) cristais de hornblenda intercrescidos em cristais de biotita. Siglas: Olg: oligoclásio; Qtz: quartzo; Mic: microclínio; Hbl: hornblenda; Gru: grunnerita; Bt: biotita.

Figura 2.6. Aspectos texturais do hornblenda-biotita granito inequigranular médio: A) afloramento em forma de lajeiro do hornblenda-biotita granito inequigranular médio; B, C e D) arranjo textural fanerítico médio.

Figura 2.7. Fotomicrografias do hornblenda-biotita granito inequigranular médio: A) visão geral da trama do hornblenda-biotita granito; B) cristais de microclínio evidenciando seu maclamento típico e plagioclásio evidenciando seu intercrescimento gráfico; C) cristal de plagioclásio evidenciando seu intercrescimento gráfico; D) cristais de biotita parcialmente cloritizados e 
apresentando contatos serrilhados com os feldspatos. Siglas: Olg: oligoclásio; Qtz: quartzo; Mic: microclínio; Hbl: hornblenda; Bt: biotita.

Figura 2.8. Fotografia panorâmica do biotita granito inequigranular fino visualizado dentro da frente de lavra de uma das cavas da Mina Liberdade e em contato com sedimentos inconsolidados por vezes mineralizados.

Figura 2.9. Fotografias do biotita granito inequigranular fino visualizado dentro da frente de lavra da Mina Liberdade: A e B) contato com sedimentos inconsolidados por vezes mineralizados e contato com o veio mineralizado, respectivamente; C) trama da rocha; D) veio quartzo-feldspático cortando a trama da rocha.

Figura 2.10. Características geoquímicas dos granitos da SIAC: A) o índice de saturação em alumina (ISA ou A/CNK) de Shand, segundo Maniar e Piccoli (1989); B) o índice de alcalinidade segundo Irvine e Baragar (1971); C) diagrama do teor de potássio com base na correlação entre $\mathrm{K}_{2} \mathrm{O} \times \mathrm{SiO}_{2}$, modificado de Le Maitre (1989, in Rollinson 1993).

Figura 2.11. Comparação entre os padrões de distribuição dos ETR e multielementos dos granitos da SIAC, com valores normalizados, respectivamente, segundo os condritos de Boynton (1984) e o Manto Primordial de Wood et al. (1979): A e B) SIAC Fácies 1; C e D) SIAC Fácies 2; E e F) SIAC Fácies 3.

Figura 2.12. Diagramas de Classificação Química de Rochas Plutônicas aplicados às rochas da SIAC. Em A, Diagrama multicatiônico $\mathrm{R}_{1} \times \mathrm{R}_{2}$ de De La Roche et al. (1980); em B, diagrama TAS de Cox et al. (1979, modificado de Le Maitre et al. 1989); e, em C, diagrama TAS de Middlemost, (1994).

Figura 2.13. Diagrama de correlação do tipo Harker para elementos maiores vs. $\mathrm{SiO}_{2}$, aplicado às rochas da SIAC.

Figura 2.14. Diagrama de correlação do tipo Harker para elementos traços vs. $\mathrm{SiO}_{2}$, aplicado às rochas da SIAC.

Figura 2.15. Diagramas $\mathrm{Na}_{2} \mathrm{O}+\mathrm{K}_{2} \mathrm{O}-\mathrm{CaO}$ e $\mathrm{FeO} /\left(\mathrm{FeO}_{\mathrm{t}}+\mathrm{MgO}\right)$ vs. $\mathrm{SiO}_{2}$, aplicados às rochas da SIAC, modificado de Frost et al. (2001).

Figura 2.16. Diagramas discriminantes aplicados para tipologia de granitos e elaborados a partir das correlações entre a razão $10^{4} \mathrm{Ga} / \mathrm{Al} \times \mathrm{K}_{2} \mathrm{O}+\mathrm{Na}_{2} \mathrm{O}, \mathrm{K}_{2} \mathrm{O}+\mathrm{Na}_{2} \mathrm{O} / \mathrm{CaO}, \mathrm{Nb}, \mathrm{Zr}$, Ce e Y. Observar as amostras das fácies da SIAC distribuídas no campo dos granitos do tipo A (Whalen et al. 1987).. 33

Figura 2.17. Diagramas discriminantes aplicados para tipologia de granitos, elaborados a partir da correlação entre a razão $10^{4} \mathrm{Ga} / \mathrm{Al} \times \mathrm{Eu} / \mathrm{Eu} *$ e $\mathrm{Zr}+\mathrm{Nb}+\mathrm{Ce}+\mathrm{Y} \times 10^{4} \mathrm{Ga} / \mathrm{Al}$, além dos diagramas discriminantes para divisão dos granitos tipo $A$ nos subtipos $A_{1}$ e $A_{2}$, aplicados às rochas das fácies da SIAC. Observar as amostras das fácies da SIAC distribuídas no campo dos granitos do tipo A subtipo A 2 (Eby 1992). 
Figura 2.18. Diagramas discriminantes de granitos tipo A e cálcio-alcalinos e granitos tipo A reduzidos e oxidados e cálcio-alcalinos, aplicados às rochas das fácies da SIAC, segundo Dall'Agnol e Oliveira (2007).

Figura 2.19. Diagramas discriminantes de ambientes tectônicos aplicados às rochas das fácies da SIAC, segundo Pearce et al. (1984). Siglas: $\mathrm{WPG}=$ granitos intraplaca, $O R G=$ granitos de cadeias oceânicas, VAG = granitos de arco vulcânico, Syn-COLG = granitos sincolisionais e Post-COLG = granitos pós-colisionais.

\section{CAPÍTULO 3}

Figura 3.1. Fotografias representantes dos veios mineralizados que compõe o depósito de estanho Liberdade: A) veio mineralizado em contato com o biotita granito inequigranular fino (fácies 3); B) blocos de cassiterita maciça extraída do veio mineralizado; C) bloco do veio mineralizado com cristais de cassiterita e arsenopirita oxidada; D) fotomicrografia com nicóis paralelos de uma porção do veio, colocado em condições de cisalhamento, formando uma estruturação milonítica no mesmo.

Figura 3.2. Fotografias do veio mineralizado: a) microzonas de cisalhamento mineralizadas, encontradas em pequenas fraturas no granito, em escala de afloramento; b) veio de quartzo bastante fraturado; c \& d) imagem de elétrons retro espalhados (MEV) evidenciando a relação da cassiterita com a arsenopirita. Siglas: Cst: Cassiterita; APy: Arsenopirita.

Figura 3.3. Fotografias do quartzo-muscovita greisen com fluorita dentro da área do depósito de estanho Liberdade: a, b \& c) material da cúpula greisenizada totalmente alterada; d) amostra do quartzo-muscovita greisen com fluorita retirado do contato entre o veio mineralizado e a rocha encaixante pertencente a SIAC.

Figura 3.4. Diagrama de classificação de greisens de Kühne et al. (1972, in Stemprok 1987).

Figura 3.5. Fotomicrografias do quartzo-muscovita greisen com fluorita mapeado dentro da área do depósito de estanho Liberdade: A) trama do greisen, evidenciando a relação quartzo-muscovita e muscovita-muscovita; B) mesma fotomicrografia exibida em A, porém com os nicóis cruzados; C e D) relações da ilmenita e arsenopirita com os cristais de muscovita. Siglas: APy: Arsenopirita; Ilm: Ilmenita; Ms: Muscovita; Qtz: Quartzo.

Figura 3.6. Fotomicrografias mostrando cristais de cassiterita do quartzo-muscovita greisen com fluorita: a \& b) imagem de elétrons retroespalhados (MEV) mostrando cristais de cassiterita fraturados, onde as fraturas estão preenchidas por sulfetos (arsenopirita e pirita); c \& d) cristais de cassiterita fraturados e apresentando zoneamento.

Figura 3.7. Sequência esquemática de cristalização mineral no quartzo-muscovita greisen com fluorita do depósito de estanho Liberdade.

Figura 3.8. Fotomicrografias mostrando as relações entre os minerais do greisen: A e B) imagem de elétrons retroespalhados (MEV) mostrando cristais de arsenopirita moderadamente fraturados; C) fotomicrografia mostrando a associação arsenopirita-pirita; D) imagem de elétrons retro 
espalhados (MEV) mostrando cristal de ilmenita apresentando exsolução de titanita. E e F) Imagem de elétrons retroespalhados (MEV) mostrando a relação da xenotímia com a thorita. Notar que a thorita apresenta seus cristais sob a forma de inclusões na xenotímia.Siglas: APy: Arsenopirita; Py: Pirita; Tit: Titanita; Xt: Xenotímia; Th: Thorita.

Figura 3.9. Fotografias de garimpo e sedimentos colúvio-aluvionares: A) região de garimpo; B) planta de concentração utilizada pela lavra garimpeira; C e D) visão da área lavrada por garimpeiros, onde estão explotando um material arenoso, areno-argiloso e argilo-arenoso, ricos em cassiterita; E e F) visão geral de uma das cavas da mina Liberdade, onde percebe-se um contato brusco dos sedimentos coluvionares mineralizados com o biotita granito inequigranular fino.

Figura 3.10. Modelos estruturais propostos para a região do depósito de estanho Liberdade: A) Interpretação em bloco diagrama do aspecto geral da geometria dos veios mineralizados do depósito de estanho Liberdade; B) Modelo de Riedel simplificado para as fraturas do Depósito de Estanho Liberdade.

Figura 3.11. Amostra de cassiterita do veio mostrando sua relação com a arsenopirita, fluorita e quartzo. Siglas: Cst: Cassiterita; APy: Arsenopirita; Qtz: quartzo; Fl: Fluorita

Figura 3.12. Sequência de análises pontuais por microssonda eletrônica em cristais de cassiterita zonados mostrando as variações na composição química para óxidos em \% em peso. 48

Figura 3.13. Diagramas de correlações aplicados às cassiteritas de veio, mostrando a variação nos conteúdos de $\mathrm{FeO}_{\text {(total) }}, \mathrm{Nb}_{2} \mathrm{O}_{5}$ e $\mathrm{WO}_{3}$, em relação ao conteúdo de $\mathrm{SnO}_{2}$

\section{CAPÍtULO 4}

Figura 4.1. Diagrama Concórdia para análises LA-ICP-MS obtidas em grãos de zircão das amostras CNRO-008 (A), CNRO-007 (B) e CNRO-001D (C), representando a idade das rochas graníticas da Suíte Intrusiva Alto Candeias no depósito de estanho Liberdade.

Figura 4.2. Evolução isotópica $\mathrm{Sm}-\mathrm{Nd}$ (idades e $\varepsilon \mathrm{Nd}$ ) para os fácies graníticos da Suíte Intrusiva Alto Candeias encontrados no depósito de estanho Liberdade.

Figura 4.3. Gráficos: A) Idades platô ${ }^{40} \mathrm{Ar} /{ }^{39} \mathrm{Ar}$; B) relações $\mathrm{Ca} / \mathrm{K}$ e $\mathrm{Cl} / \mathrm{K}$ da muscovita da amostra CNRO-003 aplicadas ao cálculo da Idade Ar-Ar.

Figura 4.4. Diagrama $\delta \mathrm{D}_{\text {fluido }} \mathrm{x} \delta^{18} \mathrm{O}_{\text {água }}$ mostrando os dados de amostras de muscovita dos veios e greisen do depósito de estanho Liberdade, segundo Kerrich (1989).

\section{CAPÍTULO 5}

Figura 5.1. Modelo esquemático de compartimentação geológica e evolução metalogenética proposto para o depósito de estanho Liberdade. 


\section{LISTA DE TABELAS}

\section{CAPÍTULO 2}

Tabela 2.1. Resultados de análises químicas das fácies graníticas mapeadas da Suíte Intrusiva Alto Candeias

\section{CAPÍtULLO 3}

Tabela 3.1. Dados das análises por microssonda eletrônica em cristais de cassiterita. Composições dos óxidos em \% em peso e dos elementos em átomos por fórmula unitária, calculada na base de 2 oxigênios para cassiterita.

\section{CAPÍTULO 4}

Tabela 4.1. Dados isotópicos para os granitos da Suíte Intrusiva Alto Candeias

Tabela 4.2. Sumário dos dados LA-ICP-MS obtidos nas amostras CNRO-008 (Fácies 1), CNRO007 (Fácies 2) e CNRO-001D (Fácies 3).

Tabela 4.3. Composição isotópica $\mathrm{Sm}-\mathrm{Nd}$ das rochas graníticas pertencentes a Suíte Intrusiva Alto

Candeias.

Tabela 4.4. Dados analíticos ${ }^{40} \mathrm{Ar}-{ }^{39} \mathrm{Ar}$ da amostra CNRO-003 sumarizados.

Tabela 4.5. Dados analíticos disponíveis para depósitos de estanho relacionados a Província Estanífera de Rondônia.

Tabela 4.6. Amostras de minerais com seus respectivos valores de isótopos de $\delta^{18} \mathrm{O}$.

Tabela 4.7. Fracionamento isotópico do oxigênio em cassiterita, cujos parâmetros isotópicos A, B e $\mathrm{C}$ foram utilizados para o cálculo da temperatura nos veios e greisens do Depósito de Estanho Liberdade, segundo os parâmetros estabelecidos por Zhang et al. (1994)

Tabela 4.8. Valores calculados para as temperaturas de cristalização e para a composição isotópica dos fluidos hidrotermais $\left(\delta^{18} \mathrm{O} \mathrm{H}_{2} \mathrm{O}\right)$.

Tabela 4.9. Amostras de minerais com seus respectivos valores de isótopos de $\delta \mathrm{D}$. 


\section{CAPÍTULO 1}

\section{INTRODUÇÃO}

\subsection{APRESENTAÇÃO}

Esta pesquisa faz parte do Programa de Pós-Graduação em Geologia da Universidade de Brasília (UnB), aqui apresentada sob a forma de dissertação como requisito básico para a obtenção do título de Mestre em Geologia. O objeto desta pesquisa é o depósito de estanho Liberdade e seu entorno, Província Estanífera de Rondônia (PER), Estado de Rondônia, enfocando suas características geológicas, metalogenéticas e geocronológicas.

O depósito de estanho Liberdade foi descoberto no início da década de 2000, durante a última "corrida" por metais em Rondônia. Entretanto, devido à crise econômica mundial, deflagrada na segunda metade da década de 2000, as atividades de pesquisa e extração nesses depósitos foram paralisadas. Em meados de 2010, a empresa Metalmig Mineração Indústria e Comércio LTDA, detentora dos direitos minerários, retomou as atividades exploratórias no depósito e as encerrou no início de 2011. Esse depósito produziu cerca de 1000 toneladas de minério de estanho (cassiterita $\mathrm{SnO}_{2}$ ), segundo informações não oficiais de técnicos da referida empresa.

\subsection{LOCALIZAÇÃO E ACESSOS}

O depósito de estanho Liberdade está localizado no município de Campo Novo de Rondônia, região centro-oeste do Estado de Rondônia, distante cerca de $310 \mathrm{~km}$ ao sul da capital Porto Velho. Está limitado pela interseção entre o paralelo $10^{\circ} 38^{\prime} 19,4$ " S e o meridiano $63^{\circ} 40^{\prime} 19,1$ " W (Figura 1.1). O acesso é realizado pela BR-364, partindo-se de Porto Velho até ao trevo de acesso à BR-421, localizado na cidade de Ariquemes. A partir desse trevo, segue-se pela BR-421 por cerca de mais 110 km, até a sede do município de Campo Novo de Rondônia. De Campo Novo de Rondônia segue-se por estrada vicinal por cerca de $14 \mathrm{~km}$ até a área do depósito.

\subsection{PROBLEMÁTICA E JUSTIFICATIVA DA PESQUISA}

O Estado de Rondônia, em sua região centro-norte, aloja várias suítes graníticas geradas durante sucessivos episódios magmáticos entre 1606 e 974 Ma (Kloosterman 1968, Priem et al. 1966, Priem et al. 1971, Leal et al. 1978, Isotta et al. 1978, Bettencourt et al. 1997, Bettencourt et al. 1999a, Quadros 2007, Santos et al. 2008). Tais suítes graníticas formam a chamada Província Estanífera de Rondônia, com expressivas concentrações metálicas ( $\mathrm{Sn}, \mathrm{W}, \mathrm{Nb}, \mathrm{Ta}$ ), além de $\mathrm{F}$ e gemas, associadas aos três últimos episódios magmáticos (1314 e 974 Ma; Bettencourt et al. 1999a), representados pelas Suíte Intrusiva São Lourenço-Caripunas (SISLC; 1314-1309 Ma), Suíte Intrusiva Santa Clara (SISC; 1082-1074 Ma) e Suíte Intrusiva Rondônia, anteriormente designada por Young Granites of Rondônia (SIR; 998-974 Ma).

O depósito de estanho Liberdade está inserido no contexto geológico de uma zona de cisalhamento rúptil-dúctil encaixada em rochas graníticas da Suíte Intrusiva Alto Candeias (SIAC), cuja idade varia entre 1357 e 1329 Ma (Bettencourt et al. 1999a, Santos et al. 2000, Santos et al. 2002, Santos et al. 2008, Bettencourt et al. 2010, Scandolara et al., em preparação).

Segundo Bettencourt et al. (1999a), a SIAC não representa um episódio magmático portador de mineralizações na Província Estanífera de Rondônia e sugerem que os registros de mineralizações polimetálicas dentro do contexto da SIAC estariam associados às outras fases magmáticas intrusivas mais jovens. 


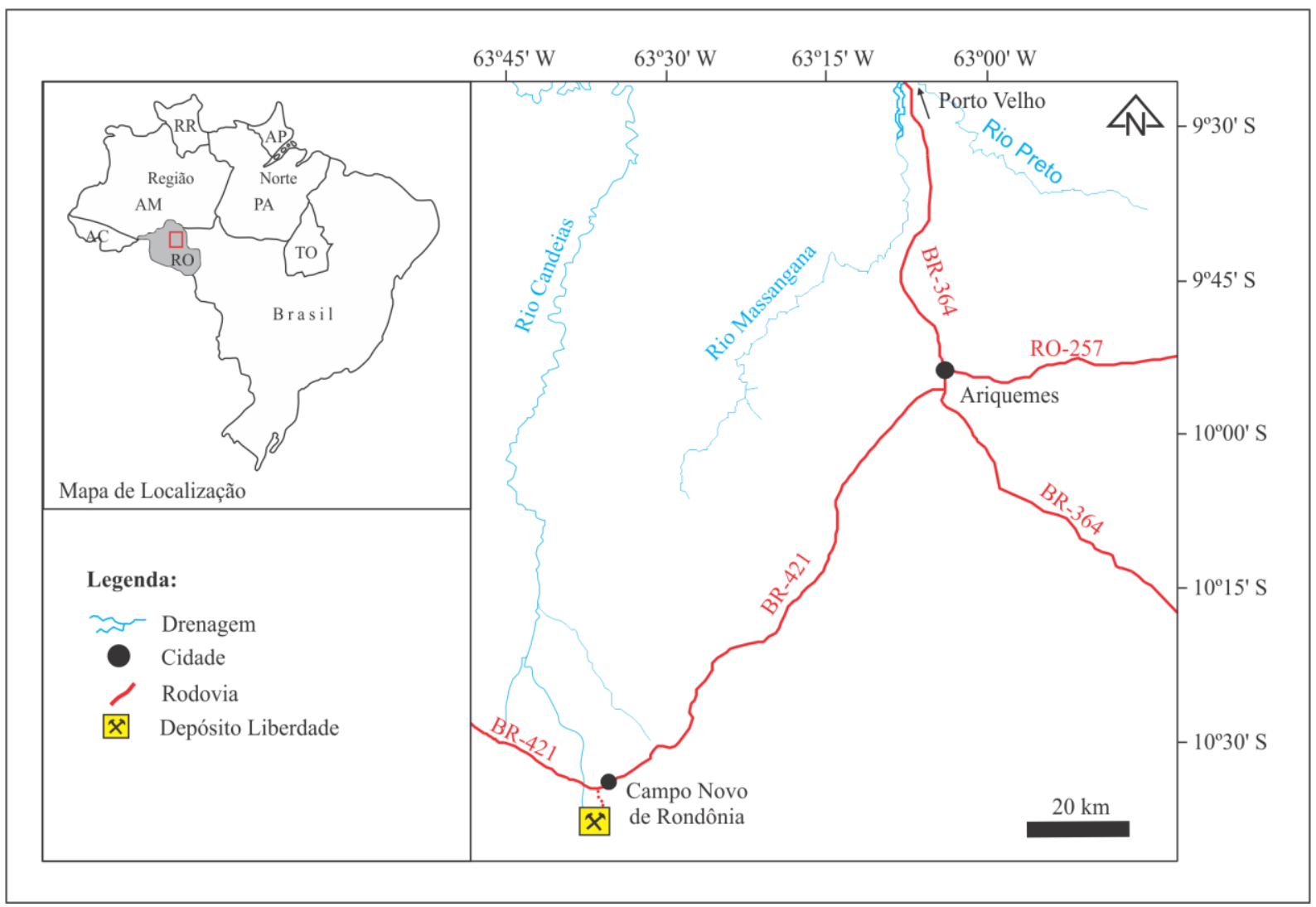

Figura 1.1. Mapa de localização do depósito de estanho Liberdade.

Considerando o contexto geológico do depósito de estanho Liberdade, esta pesquisa se justifica pela oportunidade de se obter informações que possibilitem esclarecer a natureza e condições físico-químicas responsáveis pela mineralização, bem como a idade desse processo, seu respectivo episódio magmático e sua relação com a rocha encaixante.

\subsection{OBJETIVOS}

O objetivo geral desta pesquisa consiste em caracterizar o contexto geológico e os processos metalogenéticos envolvidos na gênese do depósito de estanho Liberdade e entorno. Para tal, busca-se alcançar os seguintes objetivos:

- Caracterização petrográfica e geoquímica dos principais tipos de rochas (magmáticas e hidrotermais);

- Caracterização petrográfica da paragênese mineral associada à mineralização de estanho;

- Caracterização do contexto geológico-estrutural da frente de lavra;

- Caracterização isotópica ( $\mathrm{Sm}-\mathrm{Nd}$ e $\mathrm{U}-\mathrm{Pb}$ ) dos diferentes tipos de rochas magmáticas identificados;

- Estudo de isótopos estáveis $(\mathrm{O}$ e $\mathrm{H})$ e radiogênicos (Ar-Ar) sobre a paragênese mineral silicatada, com a finalidade de demonstrar a natureza dos fluidos mineralizantes, a temperatura de fechamento isotópico ou de formação da mineralização e a idade desse sistema hidrotermal;

- Estudo de química mineral da cassiterita com o objetivo de se obter sua composição química, bem como os elementos que contaminam este mineral-minério. 
- Propor um modelo geológico e metalogenético para explicar os processos geológicos e metalogenéticos envolvidos na gênese do deposito de estanho Liberdade.

\subsection{MATERIAS E MÉTODOS}

Esta pesquisa foi desenvolvida nas seguintes etapas de trabalho: 1) pesquisa bibliográfica; 2) pesquisa de campo; 3) pesquisa laboratorial; e 4) tratamento e interpretação das informações obtidas.

$\mathrm{Na}$ etapa de pesquisa bibliográfica foram coletadas informações a respeito do estado de conhecimento geológico da Província Estanífera de Rondônia, além de relatórios técnicos, mapas geológicos e imagens de satélite, disponibilizados pela empresa Metalmig e pela CPRM - Serviço Geológico do Brasil (residência de Porto Velho-RO). Foram também coletadas informações bibliográficas sobre as características geológicas, geoquímicas, geocronológicas e metalogenéticas de outras províncias estaníferas no mundo com o objetivo de municiar a pesquisa de informações científicas atualizadas.

A etapa de pesquisa de campo foi realizada em dois períodos: 25 de outubro a 01 de novembro de 2009 e 15 a 23 de agosto de 2010. Nessa etapa foram realizados mapeamentos geológicos de detalhe na frente de lavra, acompanhado de coleta de amostras, objetivando entender as relações de campo entre rocha hospedeira e mineralização, bem como definir o contexto geológico da área em torno ao depósito de estanho Liberdade.

A etapa de pesquisa laboratorial exigiu uma maior carga de tempo, na qual as amostras coletadas durante a etapa de campo foram então identificadas, selecionadas e submetidas às seguintes análises:

- Descrição petrográfica de 50 lâminas delgadas polidas de rochas, ressaltando os arranjos microtexturais e as associações minerais, realizadas no Laboratório de Microscopia do Instituto de Geociências da Universidade de Brasília (IG-UnB). Nesse estudo utilizou-se microscópio da marca Olympus equipado com objetivas de até 100x e ocular de 10x;

- Análise química em 15 amostras de rocha total, britadas e pulverizadas em panela de ágata, produzindo cerca de $20 \mathrm{~g}$ de material. Alíquotas de cerca de $10 \mathrm{~g}$ de amostras foram então encaminhadas ao laboratório ACME - Analytical Laboratories LTDA (VancouverCanadá). Os pacotes de análises escolhidos foram os grupos 4A (elementos maiores e menores) e 4B (alguns elementos traços e todos os elementos terras raras), aplicados a análises por ICP-AES e ICP-MS, respectivamente;

- Investigação por microscopia eletrônica de varredura (MEV) sobre 10 lâminas delgadas polidas, realizada no laboratório de microscopia eletrônica do Instituto de Criminalística da Polícia Federal (Brasília-DF). Utilizou-se o equipamento da marca FEI, modelo Quanta 2003D. Para a obtenção das imagens por elétrons retroespalhados (backscattered electrons ou BSE) utilizou-se aceleração de voltagem de $20 \mathrm{kV}$, distância de trabalho de $15 \mathrm{~mm}$ e tempo de contagem de 30". As micro-análises foram realizadas através de detector EDS (Energy Dispersive Spectrometer) marca Oxford, acoplado ao MEV, cujas análises foram processadas por analizador multicanal Q500 utilizando software próprio;

- Investigação por microssonda eletrônica sobre cassiterita foram realizadas em 13 lâminas polidas da mineralização. As análises foram realizadas no laboratório de microssonda eletrônica do Instituto de Geociências da Universidade de Brasília (IG-UnB). Utilizou-se o equipamento da marca JEOL, modelo Superprobe JXA-8230, acoplado com 5 espectrômetros e detector EDS (Energy Dispersive spectrometer). Para a obtenção de imagens por elétrons retroespalhados (backscattered electrons ou BSE) utilizou-se 
aceleração de voltagem variando de 15 (a maioria dos minerais) e $20 \mathrm{kV}$ (cassiterita). Para cada canal analizado condições específicas foram utilizadas.

- Análises de isótopos estáveis de Oxigênio em cassiterita e quartzo e Hidrogênio em micas foram realizadas no laboratório da Scottish Universities Research \& Reactor Center (Glasgow-Escócia), sob a supervisão do Prof. A.E. Fallick, as quais objetivaram caracterizar a temperatura e a natureza dos fluidos responsáveis pela mineralização de estanho. Tais análises foram realizadas em amostras minerais puras $(\sim 30 \mathrm{mg})$ empregando métodos de diluição e posterior extração e leitura do conteúdo isotópico, segundo o procedimento adotado por Fallick et al. (1993).

- A análise geocronológica ${ }^{40} \mathrm{Ar} /{ }^{39} \mathrm{Ar}$ foi realizada no laboratório de geologia isotópica da Queen's University, Department of the Geological Sciences \& Geological Engineering (Ontário-Canadá), sob a supervisão do Prof. D.A. Archibald. Foi aplicada em 32 amostras de mica do greisen, as quais foram irradiadas por cerca de 40 horas em um reator nuclear do tipo McMaster. Foi empregado um laser de íon específico (Ar) de 8w tipo Lexel 3500, um espectrômetro de massa do tipo MAP 216, com fonte Signer Baur e um multicoletor de elétrons. As medidas dos isótopos de argônio são normalizadas à razão atmosférica ${ }^{40} \mathrm{Ar} /{ }^{36} \mathrm{Ar}$ usando as razões propostas por Roddick (1983). As idades e os erros foram corrigidos usando as fórmulas propostas por Steiger e Jäger (1977) e Dalrymple et al. (1981). As idades e erros apresentados representam uma precisão analítica de $2 \sigma$ ou $0,5 \%$, adequados ao espectro de variação para forma de platô (McDougall e Harrison 1988). As idades obtidas foram referenciadas para o padrão $\mathrm{Hb}_{3} \mathrm{Gr}$ (hornblenda) em $1072 \mathrm{Ma}$ (Roddick 1983).

- As análises isotópicas ( $\mathrm{Sm}-\mathrm{Nd}$ e U-Pb) dos diferentes tipos de rochas graníticas foram realizadas no Laboratório de Geocronologia e Geologia Isotópica da UnB, aplicando-se o seguinte procedimento analítico:

- $S m-N d: 8$ amostras de rochas foram analisadas (rocha-total) segundo os procedimentos descritos por Gióia e Pimentel (2000). Cerca de $50 \mathrm{mg}$ de rocha foram pulverizadas em panela de ágata, misturadas com solução de spike ${ }^{149} \mathrm{Sm}-{ }^{150} \mathrm{Nd}$ e dissolvidas em cápsulas de Savillex. A extração de Sm e Nd seguiu a técnica convencional com colunas de Teflon contendo LN-Specresin (HDEHP - diethylhexil phosphoric acid supported on PTFE powder). As amostras de Sm e Nd foram alojadas em filamentos de re-evaporação em conjuntos de filamentos duplos e as medidas isotópicas foram feitas em espectrômetro de massa do tipo multicoletor Finnigan MAT 262. O grau de incertezas para as razões ${ }^{149} \mathrm{Sm} /{ }^{150} \mathrm{Nd}$ e ${ }^{143} \mathrm{Nd} /{ }^{144} \mathrm{Nd}$ é menor que $\pm 0,4 \%(1 \sigma)$ e $\pm 0,005 \%(1 \sigma)$, respectivamente, de acordo com análises do padrão internacional BHVO-1 e BCR-1. As razões ${ }^{143} \mathrm{Nd} /{ }^{144} \mathrm{Nd}$ foram normalizadas para ${ }^{146} \mathrm{Nd} /{ }^{144} \mathrm{Nd} \mathrm{de}$ 0,7219 , e a constante de decaimento usada foi $6,54 \times 10^{-12}$ a $10^{-1}$. Valores TDM foram calculados segundo método de DePaolo (1981).

- $U-P b: 5$ amostras de diferentes fácies graníticas foram selecionadas. Cada amostra foi triturada, peneirada e bateada para aquisição de um concentrado mineral, do qual foram separados cristais de zircão por meio de lupa binocular. De cada amostra um conjunto entre 30 e 40 zircões foram selecionados e colocados em uma capsula plástica medindo $1 \mathrm{~cm}$ de diâmetro, sendo posteriormente polidos a fim de expor sua superfície. As amostras foram analisadas seguindo o procedimento analítico proposto por Bühn et al. (2009) para o método LA-ICPMS (laser ablation inductively coupled plasma mass spectrometer), com equipamento do modelo Neptune da Thermo 
Finnigan, equipado com 9 copos faraday, 1 multiplicador de elétrons e 5 contadoras de íons do tipo MIC (multi íon channel). O método consiste de um equipamento de ablação a laser acoplado a um espectrômetro de massa que permite a obtenção de razões isotópicas in situ com alta resolução espacial em monocristais de zircão.

Finalmente, na etapa de tratamento e interpretação das informações obtidas, buscou-se integrar todas as informações adquiridas nas etapas anteriores, ilustrar e tratar por meio de gráficos e diagramas específicos, cujas interpretações e conclusões estão redigidas nesta Dissertação de Mestrado.

\subsection{SÍNTESE DO CONHECIMENTO GEOLÓGICO REGIONAL}

O Estado de Rondônia contém a terceira maior reserva de estanho do Brasil (Quadros 2007), justificando a investigação geológica e metalogenética na região, cujos resultados são um considerável volume de informações disponíveis em mapas, relatórios técnicos, artigos científicos, dissertações de mestrado, teses de doutorado, etc. Abaixo, está descrito, de modo sintético, a evolução do conhecimento geológico da região centro-norte de Rondônia, enfatizando sua contextualização geotectônica e litoestratigráfica.

\subsubsection{Contexto Geotectônico}

O Cráton Amazônico (Almeida 1978) tem sido alvo de muitos estudos acerca de sua compartimentação e evolução geotectônica. A compreensão do quadro evolutivo do Cráton Amazônico pode ser apresentada em três concepções:

A primeira concepção é baseada em informações geológicas, geofísicas e isotópicas ( $\mathrm{Rb}$-Sr e $\mathrm{K}-\mathrm{Ar}$ ), as quais dividiram o Cráton Amazônico em províncias e subprovíncias estruturais, separadas pelas coberturas sedimentares das Bacias do Solimões e Amazonas (Figura 1.2A). Segundo esta concepção, sucessivas reativações ocorreram durante o Proterozóico Médio à Superior em uma extensa plataforma continental cratônica de idade Arqueano-Proterozóico Inferior, gerando vulcanismo e granitogênese anorogênica (Almeida 1974, Amaral 1974, Almeida 1978, Montalvão e Bezerra 1980, Almeida et al. 1981, Amaral 1984, Schobbenhaus e Campos 1984).

A segunda concepção (Figuras 1.2B, 1.2C) é baseada em informações geológicas, geofísicas e, principalmente, isotópicas ( $\mathrm{Rb}-\mathrm{Sr}, \mathrm{K}-\mathrm{Ar}, \mathrm{Pb}-\mathrm{Pb}, \mathrm{U}-\mathrm{Pb}$ e $\mathrm{Sm}-\mathrm{Nd}$ ), as quais dividiram o Cráton Amazônico em províncias geocronológicas (Cordani et al. 1979, Tassinari 1981, Cordani e Neves 1982, Gibbs e Barron 1983, Gaudette e Olszewski Jr. 1985, Litherland et al. 1986, Litherland et al. 1989, Teixeira et al. 1989, Tassinari 1996, Sato e Tassinari 1997, Tassinari e Macambira 1999, Santos 2000, Santos et al. 2000, Tassinari e Macambira 2004, Santos et al. 2004, Santos et al. 2006, Santos et al. 2008, Bettencourt et al. 2010, Teixeira et al. 2010). Segundo essa concepção, a evolução geotectônica da região ocorreu ao redor de um núcleo arqueano (> 2,5 Ga), em torno do qual se desenvolveram, durante o Proterozóico, vários cinturões orogenéticos (2,2-1,0 Ga), a partir de acresção de material juvenil e retrabalhamento crustal durante o Paleoproterozóico (idades-modelo

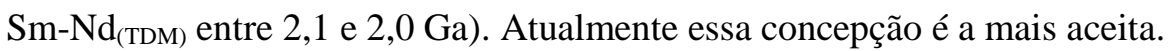

A terceira concepção é baseada em informações geofísicas e geológicas, as quais dividiram a região em vários blocos crustais ou paleoplacas, formadas internamente por terrenos do tipo granitogreenstone e bordas limitadas por cinturões de cavalgamentos e transcorrências (Figura 1.2D), onde ocorrem granulitos, gnaisses, rochas supracrustais e granitóides, sendo consequência de processos colisionais ocorridos no Arqueano-Proterozóico Inferior, compondo parte de um mega continente, o qual foi submetido a três ciclos de esforços extensionais registrados no Proterozóico Médio-Superior, Paleozóico e Mioceno (Hasui et al. 1984, Hasui e Haralyi 1985, Hasui 1993, Costa e Hasui 1997). 


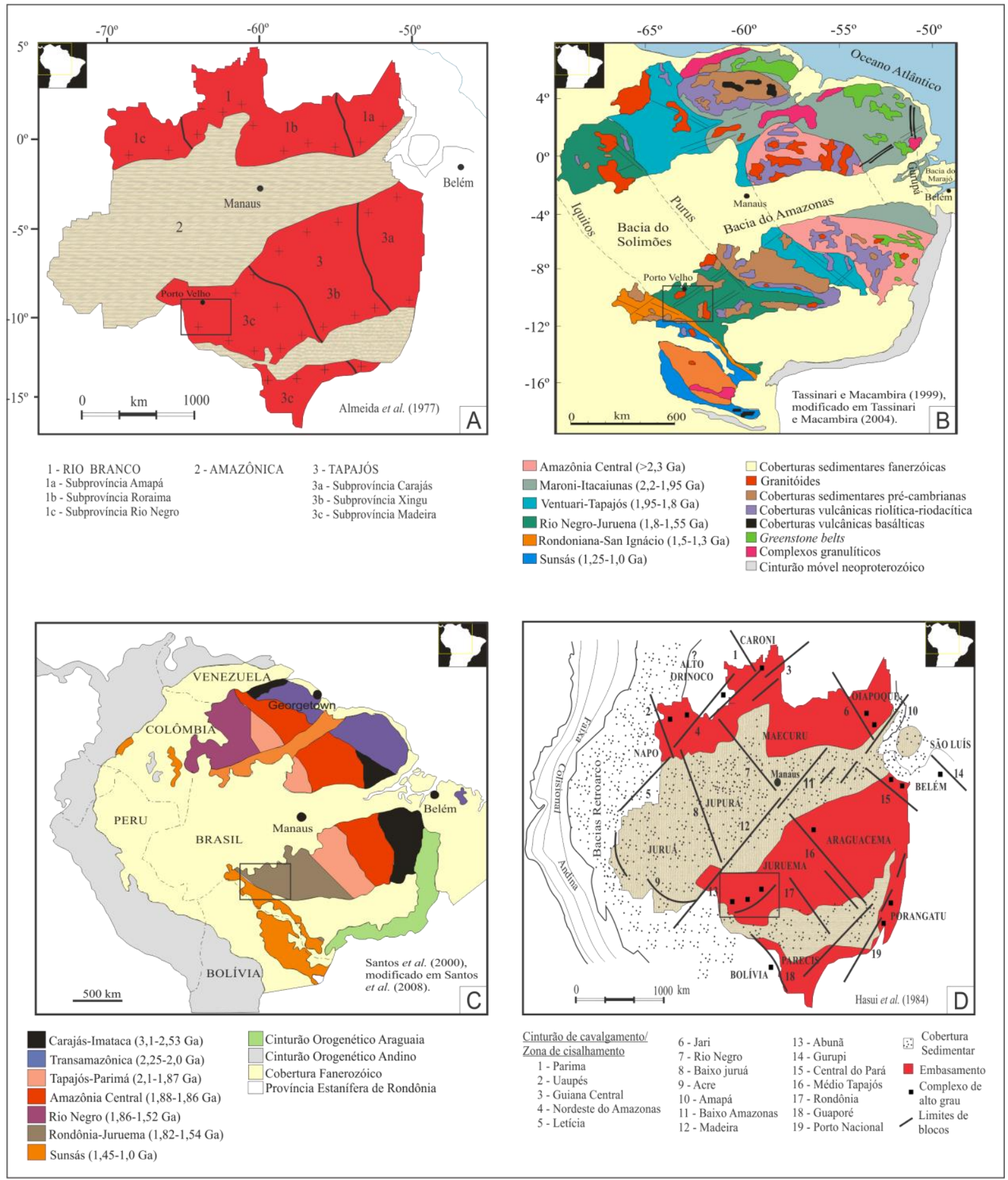

Figura 1.2. Principais propostas de compartimentação geocronológica para o Cráton Amazônico: A) proposta de Almeida et al. (1977); B) proposta de Tassinari e Macambira (1999), modificado em Tassinari e Macambira (2004); C) proposta de Santos et al. (2000), modificado em Santos et al. (2008); D) proposta de Hasui et al. (1984). O retângulo negro é a área da Província Estanífera de Rondônia.

A Província Estanífera de Rondônia está inserida na porção sudoeste do Cráton Amazônico, abrangendo duas províncias geocronológicas, segundo a concepção de Tassinari e Macambira (1999, 2004; Figura 1.2B): Província Rio Negro-Juruena (1,8-1,55 Ga) e Província Rondoniana-San Ignácio (1,5-1,3 Ga), porém com produtos de dois eventos apenas, relacionados as Províncias Rondoniana-San Ignácio (1,5-1,3 Ga) e Sunsás (1,25-1,0 Ga). Por outro lado, segundo a concepção de Santos et al. 
(2000, 2008), a Província Estanífera de Rondônia está inserida nos domínios das províncias RondôniaJuruena (1,82-1,54 Ga) e Sunsás (1,45-1,0 Ga; Figura 1.2C).

A evolução geotectônica da porção sudoeste do Cráton Amazônico, em especial na área da Província Estanífera de Rondônia, no período de 1,8 a 1,0 Ga, é marcada por eventos de acresção crustal com sucessivos episódios de magmatismo, metamorfismo e deformação regional com regimes tectônicos registrados ao longo das províncias geocronológicas Rio Negro-Juruena, Rondoniana-San Ignácio e Sunsás. A atuação de dois sistemas de arcos magmáticos nos períodos entre 1,8-1,7 e 1,61,57 é registrada na Província Rio Negro-Juruena. No sistema mais antigo ocorreram atividades graníticas e deformacionais entre 1,8 e 1,7 Ga, vulcanismo félsico e sedimentação continental entre 1,7 e 1,65 Ga, além de intrusões de granitos rapakivi entre 1,6 e 1,57 Ga. Já no sistema mais jovem, eventos de deformação e recristalização de rochas de composição granítica $\sin$ a tardi tectônicas (incluindo os granitos rapakivi de 1,6 a 1,57 Ga), vulcanismo félsico e sedimentação entre 1,5 e 1,4 $\mathrm{Ga}$, ocorreram.

Um período de estabilidade ocorre na Província Rio Negro-Juruena entre 1,6 e 1,51 Ga, sendo marcado por um regime tectônico distensivo que possibilitou a abertura de mega fraturas responsáveis pelo alojamento das suítes graníticas anorogênicas Santo Antônio, Teotônio e Alto Candeias, bem como de corpos máficos, além de estar possivelmente vinculado à orogenia Rondoniana-San Ignácio (Tassinari 1996, Tassinari et al. 1996, Tassinari et al. 2000, Scandolara et al. 2001). Bettencourt et al. (2010) sugerem que a Província Rondoniana-San Ignácio (1,56-1,30 Ga) é um orógeno composto, criado pela acresção sucessiva de arcos, onde ocorreu o fechamento de uma bacia oceânica e uma colisão oblíqua final entre um micro continente e o continente, os quais estão bem preservados principalmente no Terreno Paraguá (Bolívia e Mato Grosso - Brasil), no Cinturão Alto Guaporé e na Província Rio Negro-Juruena, além de considerar que a Província foi afetada pela deformação metamórfica e pela colisão mais tardia relacionada aos eventos da Orogenia Sunsás (1,25-1,0 Ga).

No período de 1,3 a $1,0 \mathrm{Ga}$ ocorreu a orogenia colisional Sunsás, correlacionada geocronológica, geotectônica e paleogeograficamente à orogenia Greenvilleana do final do Mesoproterozóico, ligando os crátons Amazônico, Laurentia e Báltica, como parte do supercontinente Rodínia (Hoffman 1991, Sadowski e Bettencourt 1996, Bettencourt et al. 1996, Unrug 1996, Weill et al. 1998, Tassinari et al. 2000, Geraldes et al. 2001, Buchan et al. 2001, Van Schmus 2001, Keppie et al. 2001, Condie 2001, Payolla et al. 2002). Porém, Tohver et al. (2001) e D’Agrella-Filho et al. (2001), a partir de informações isotópicas $\left({ }^{40} \mathrm{Ar} /{ }^{40} \mathrm{Ar}\right)$ e paleomagnéticas obtidas na região sudoeste do Cráton Amazônico, não evidenciam essa ligação paleogeográfica entre esses crátons. Tohver et al. (2002) reinterpretaram as informações isotópicas e paleomagnéticas obtidas em basaltos e gabros da Formação Nova Floresta, propondo a ligação da região sudoeste do Cráton Amazônico com o segmento Llano da Laurentia no início da orogênese Greenvilleana. Sadowski e Bettencourt (1996) e Tassinari et al. (2000) sugerem que a evolução tectônica da Província Sunsás é caracterizada por uma distensão continental representada por magmatismo basáltico e deposição de sedimentos dos grupos Sunsás e Vibosi (Bolívia) e do Grupo Aguapeí (Brasil) em ambiente de margem continental. Posteriormente, essa bacia teria sido fechada, durante a Orogenia Sunsás, concomitantemente à evolução da Sequência Metavulcano-sedimentar Nova Brasilândia e a formação de granitos sin tectônicos. Esses episódios foram seguidos por deformações e plutonismo alcalino, associados ao estágio evolutivo final da orogenia (Sadowski e Bettencourt 1996, Bettencourt et al. 1996, Bettencourt et al. 1999a).

Porém, segundo a concepção de Santos et al. (2008), a Província Rondônia-Juruena é marcada por três orogenias principais: Juruena (1840-1780 Ma), Jamari (1760-1740 Ma) e Quatro Cachoeiras (1670-1630 Ma), enquanto que a Província Sunsás é marcada por uma orogenia autóctone que evoluiu ao longo de uma margem continental formada predominantemente por rochas das orogenias Jamari e Quatro Cachoeiras mais rochas pós tectônicas da Suíte Intrusiva Serra Providência (1560-1540 Ma). 
Uma proposta de compartimentação tectonoestratigráfica para o Estado de Rondônia foi apresentada por Scandolara et al. (1999), os quais separam a região em Terrenos Roosevelt, Jamari e Nova Brasilândia (Figura 1.3). Os Terrenos Roosevelt e Jamari teriam evoluído desde o Paleoproterozóico, juntamente com a orogenia colisional que originou o cinturão móvel Rio NegroJuruena, enquanto que o Terreno Nova Brasilândia teria evoluído entre o Meso e Neoproterozóico, durante a orogenia colisional dos cinturões Sunsás-Greenville. Scandolara et al. (1999) subdividiram ainda o Terreno Jamari em dois domínios: Domínio Ariquemes-Porto Velho e Domínio Central de Rondônia.

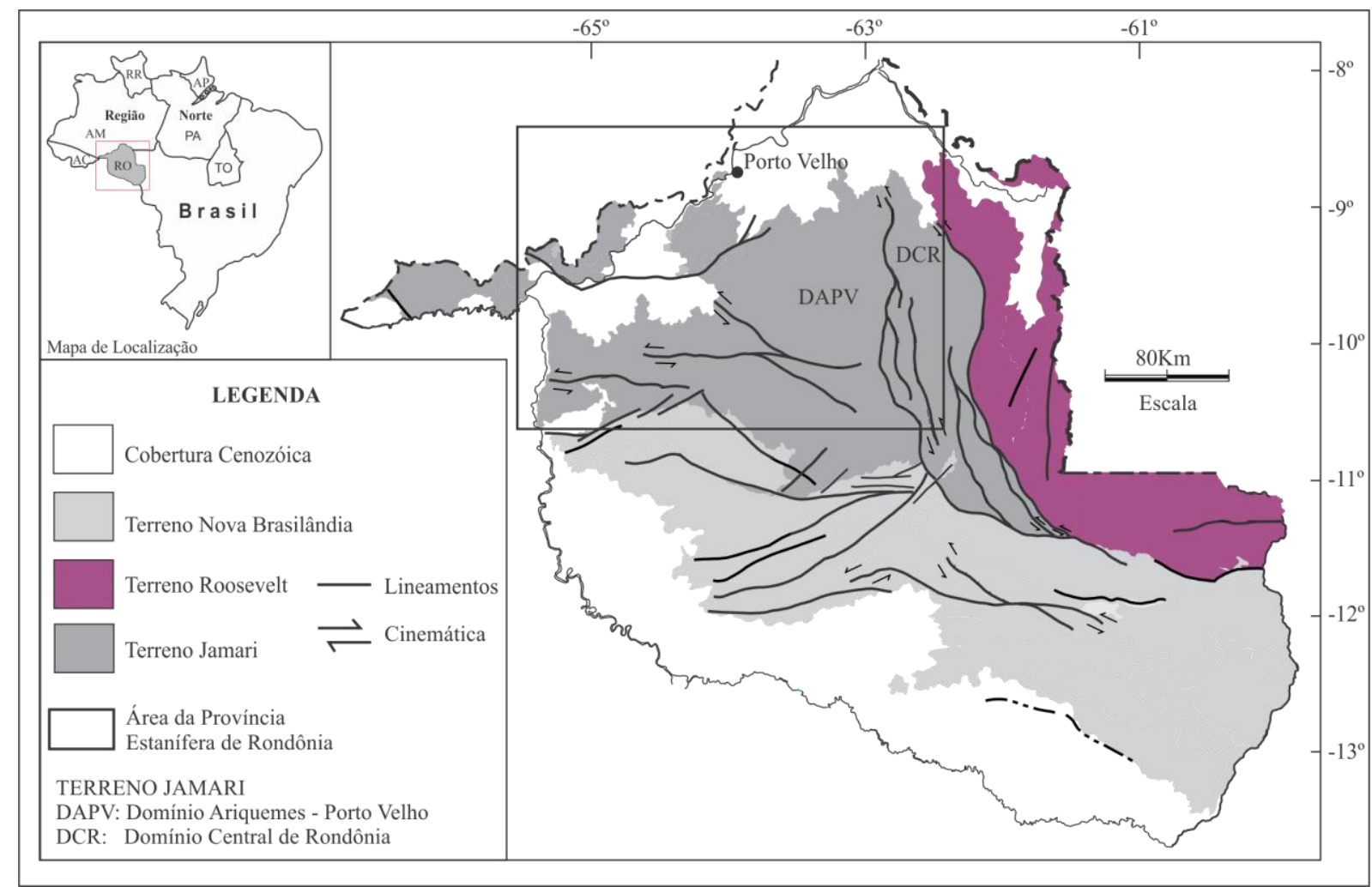

Figura 1.3. Mapa de Terrenos Tectono-Estratigráficos do Estado de Rondônia, segundo Scandolara et al. (1999).

A Província Estanífera de Rondônia está inserida no contexto do Terreno Jamari. Esta unidade tectonoestratigráfica merece atenção especial, pois hospeda diversos complexos graníticos anorogênicos, em geral, com associações de rochas rapakivíticas e contendo mineralizações de Sn, W, Nb, Ta, F, ETR, topázio e berilo (Souza 2003). Segundo Veneziani et al. (2001) e Okida (2001), a alternância de movimentos transpressivos e transtensivos regionais ao longo das principais linhas de fraqueza crustais, gerou estruturas de alívio dos tipos releasing bends e rhombo-chasms, permitindo o alojamento desses complexos graníticos.

\subsubsection{Litoestratigrafia}

A região centro-norte de Rondônia apresenta registros dos eventos magmáticos Meso a Neoproterozóicos que formam a Província Estanífera de Rondônia, intrusivos no embasamento regional de idade Paleoproterozóico (Quadros 2007, Adamy 2010). Nessa região o embasamento é representado pelo Complexo Jamari e os pulsos magmáticos são representados pelas Suítes Intrusivas Serra da Providência (1606-1526 Ma), Rio Crespo (1526-1500 Ma), Alto Candeias (1357-1329 Ma), Santa Clara (1082-1074 Ma) e Suíte Intrusiva Rondônia ou Young Granites de Rondônia (995-956 Ma). Completam esse quadro geológico as formações Nova Floresta (1192-1062 Ma) e Palmeiral (<1030 Ma), além das coberturas sedimentares do Cenozóico (Figura 1.4). 


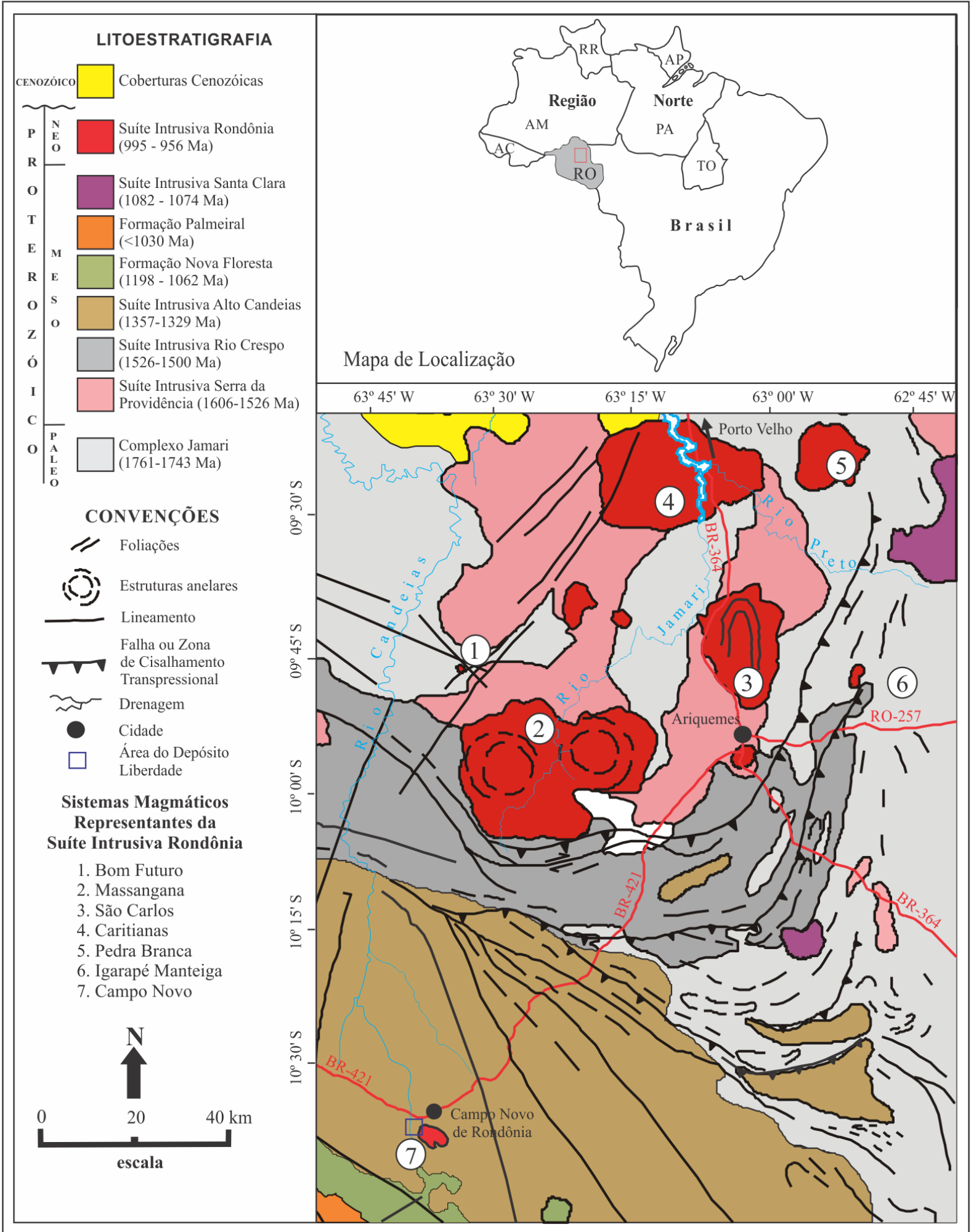

Figura 1.4. Mapa Geológico da porção centro-sul da Província Estanífera de Rondônia, segundo Quadros (2007), modificado de Adamy (2010).

\subsubsection{Complexo Jamari (CJ)}

O Complexo Jamari foi proposto por Isotta et al. (1978) para metamorfitos de alto grau, fácies anfibolito a granulito, constituído por biotita gnaisses, biotita-hornblenda gnaisses, migmatitos, granitos anatéticos, anfibolitos, granulitos e charnockitos. 
Scandolara et al. (1999) restringem o Complexo Jamari às rochas gnáissicas ortoderivadas, enquanto que os tipos paraderivados foram agrupados no Complexo Gnáissico-Migmatítico Jaru. Por outro lado, alguns autores consideram o Complexo Jamari como associação supracrustal formada por paragnaisses quartzo-feldspáticos, granada-biotita gnaisses, sillimanita gnaisses, biotititos, kinzigitos, rochas calcissilicatadas e anfibolitos, localmente, interdigitada tectonicamente com augen-gnaisses de composição granítica (monzongranítica) da Suíte Intrusiva Serra da Providência. Scandolara et al. (2001) e Scandolara (2006), devido às incertezas quanto à separação dos complexos Jamari e Jaru, propõem a fusão destes complexos sob a denominação única de Complexo Jamari, compondo o Terreno Jamari (Scandolara et al. 1999), o qual seria formado por rochas de orto e paraderivação, além de suítes graníticas intrusivas (Serra da Providência, Santo Antônio-Teotônio, Alto Candeias, São Lourenço/Caripunas, Santa Clara e Rondônia; Bettencourt et al. 1999a), coberturas supracrustais (Formação Mutum-Paraná e Grupo Roosevelt; Lobato et al. 1966, Scandolara et al. 1999, Santos et al. 2000) e coberturas sedimentares indeformadas da Formação Palmeiral (Lobato et al. 1966, Souza et al. 1975), reunidas nos domínios Ariquemes-Porto Velho e Central de Rondônia. Mais recentemente, Quadros (2007) reconsidera que o Complexo Jamari represente uma associação de ortognaisses tonalíticos e quartzo-dioríticos com subordinadas intercalações de gnaisses calcissilicáticos e raros anfibolitos, enquanto que o conjunto de rochas paraderivadas passa a constituir outra unidade designada de Suíte Metamórfica Quatro Cachoeiras.

Segundo Scandolara et al. (2013a), os ortognaisses do Complexo Jamari são metaluminosos a levemente peraluminosos de médio a alto $\mathrm{K}$, assinatura cálcio-alcalina, sugerindo que essas rochas se formaram em um arco magmático do tipo andino imaturo, enquanto que as rochas máficas apresentam assinaturas semelhantes à de toleiítos de margem continental ativa.

Investigações isotópicas (U-Pb, U-Th- $\mathrm{Pb}$ e $\mathrm{Sm}-\mathrm{Nd}$ ) sugerem que as rochas do Complexo Jamari são de fontes juvenis do manto depletado com a participação de proporções variáveis de crosta antiga reciclada (Scandolara 2006), cuja idade de cristalização magmática dos tipos ortoderivados está entre 1760 e $1730 \mathrm{Ma}$, com primeiro evento metamórfico deformacional superimposto entre 1680 e 1650 Ma (Payolla et al. 2002, Santos et al. 2002, Silva et al. 2002, Souza et al. 2005, Souza et al. 2006, Scandolara 2006). Segundo Scandolara et al. (2013a), as rochas do Complexo Jamari foram expostas a outros dois eventos associados às orogenias Rondoniana-San Ignácio (1,50 e 1,30 Ga) e Sunsás (1,30-1,00 Ga), onde ocorreram deformações entre 1,40 e 1,37 $\mathrm{Ga}$ e 1,20 e 1,15 Ga, e magmatismo, com extenso desenvolvimento de zonas de cisalhamento (Ji-Paraná Shear Zone; Scandolara et al. 1999, Scandolara 2006), cinturões miloníticos, rifts e depósitos sedimentares, além de intrusões graníticas tardi a pós colisionais do Tipo A.

\subsubsection{Suíte Intrusiva Serra da Providência (SISP)}

A Suíte Intrusiva Serra da Providência (Tassinari et al. 1984) apresenta ampla distribuição na região centro-norte de Rondônia, sendo representada, principalmente, pelo batólito granítico rapakivi Serra da Providência, além de vários stocks graníticos deformados, gabros, charnockitos e mangeritos (Bettencourt et al. 1995, Scandolara et al. 1999, Scandolara 2006, Quadros 2007, Quadros 2011, Scandolara et al. 2013b).

O batólito Serra da Providência apresenta quatro fácies petrográficas: monzogranito porfirítico (piterlitos) com viborgito subordinado, monzogranito porfirítico, monzogranito pórfiro e sienogranito granofírico, contendo enclaves quartzo-dioríticos e feições de mistura de magmas. Em geral, são rochas subalcalinas, metaluminosas a fracamente peraluminosas e apresentam uma assinatura geoquímica compatível com granitos do tipo A, subtipo A2 (Rizzotto et al. 1995, Bettencourt et al. 1995, Rizzotto e Quadros 2005, Scandolara 2006, Quadros 2007, Quadros 2011, Scandolara et al. 2013b). 
Idades de cristalização pelo método U-Pb em zircão foram determinadas para os diferentes tipos petrográficos do batólito Serra da Providência entre 1606 e 1515 Ma, com idade modelo Sm$\mathrm{Nd}_{\text {(TDM) }}$ variando de 2,05 a 1,68 Ga, sugerindo que houve participação de fontes mistas - fonte mantélica juvenil com forte contribuição de crosta antiga reciclada (Scandolara et al. 1999, Bettencourt et al. 1999a, Bettencourt et al. 1999b, Silva et al. 2002, Santos et al. 2002, Santos et al. 2008, Quadros 2011, Scandolara et al. 2013b). Idades de metamorfismo U-Pb em zircão de $1348 \mathrm{Ma}$ foram obtidas para as rochas dessa suíte, sugerindo que essa deformação superimposta estaria associada à Orogenia Rondoniana-San Ignácio (Scandolara et al. 1999, Silva et al. 2002, Santos et al. 2002, Scandolara 2006, Santos et al. 2008, Quadros 2011). Idades de resfriamento Ar-Ar entre 1.20 e $1.12 \mathrm{Ga}$, foram vinculados a eventos tectono-termais, associados à evolução de grandes estruturas transcorrentes dos sistemas de cisalhamento Ji-Paraná e Rio Formoso-Ariquemes (Scandolara et al. 1999, Tohver et al. 2002, Tohver et al. 2005, Scandolara 2006).

\subsubsection{Suíte Intrusiva Rio Crespo (SIRC)}

Proposta por Payolla et al. (2002) e atualizada por Bettencourt et al. (2006), a Suíte Intrusiva Rio Crespo é constituída dominantemente por gnaisses graníticos (gnaisses quartzo-feldspáticos) e lentes de granulitos charnockíticos, localizados na porção centro-oeste de Rondônia. Diques de anfibolitos ocorrem, localmente, ao longo da trama metamórfica regional e apresentam paragênese transicional entre a fácies anfibolito superior e granulito. Também são encontrados xenólitos de metacharnockito e granulitos máficos. Payolla et al. (2002) obtiveram dados geoquímicos que indicam que os gnaisses são metaluminosos a fracamente peraluminosos e de alto $\mathrm{K}$, apresentando assinatura geoquímica compatível com a dos granitos do Tipo A intraplaca, apesar de terem apresentado uma anomalia negativa de $\mathrm{Nb}$-Ta, típica de granitos de arco magmático.

Payolla et al. (2002) dataram, pelo método U-Pb convencional, o granulito charnockítico e o gnaisse granítico, os quais forneceram idades de mistura de $1424 \pm 10$ Ma e $1433 \pm 11 \mathrm{Ma}$, respectivamente, com idade-modelo $\mathrm{Sm}-\mathrm{Nd}_{(\mathrm{TDM})}$ de 1,73 a $1,75 \mathrm{Ga}$ e $\varepsilon \mathrm{Nd}$ de $+0,6$ a $+1,2$. Por outro lado, Bettencourt et al. (2006) dataram o gnaisse granítico pelo método U-Pb SHRIMP e obtiveram uma idade de cristalização de $1500 \mathrm{Ma}$ e um sobrecrescimento metamórfico de idade variando entre 1330 e $1350 \mathrm{Ma}$, com idade-modelo Sm-Nd(TDM) de 1,75 a 1,53 e $\varepsilon N d$ de $+1,0$ a $+1,8$, o que sugere uma fonte juvenil com contribuição do embasamento mais antigo.

\subsubsection{Suíte Intrusiva Alto Candeias (SIAC)}

Primeiramente denominada de Suíte Intrusiva Rondônia (Souza et al. 1975, Leal et al. 1978, Isotta et al. 1978), essa unidade foi definida como Suíte Intrusiva Alto Candeias por Bettencourt et al. (1997), com base em dados geocronológicos. A Suíte Intrusiva Alto Candeias é representada principalmente por um batólito granítico rapakivi, alongado na direção WNW-ESE que ocorre no sul da região centro-norte de Rondônia. O batólito Alto Candeias apresenta seis fácies distintas dominantes, ambas de caráter subalcalino: hornblenda-biotita monzogranitos, biotita monzogranitos, biotita-hornblenda monzogranitos, hornblenda-biotita sienogranitos, hornblenda-biotita sienogranitos e quartzo-monzonitos, os quais apresentam cristais ovais e tabulares centimétricos de K-feldspato pertítico, por vezes manteados por plagioclásio (Bettencourt et al. 1997, Bettencourt et al. 1999a, Santos et al. 2002, Scandolara 2006, Quadros 2007, Santos et al. 2008, Bettencourt et al. 2010, este trabalho). Sienogranitos exibindo texturas porfiríticas média a grossa e equigranulares fina a média, normalmente com charnockitos associados, são localmente identificados (Bettencourt et al. 1997, Bettencourt et al. 1999a, Payolla et al. 2002, Santos et al. 2002, Scandolara 2006, Santos et al. 2008, Bettencourt et al. 2010).

Dados geoquímicos mostram que os granitos dessa suíte são, em geral, metaluminosos a peraluminosos, subalcalinos de alto $\mathrm{K}$ e apresentando assinaturas geoquímicas compatíveis aos de 
granitos intraplaca do Tipo A, subtipo A2 (Bettencourt et al. 1997, Bettencourt et al. 1999a, Scandolara 2006, Quadros 2007, Santos et al. 2008, Bettencourt et al. 2010, este trabalho).

Bettencourt et al. (1995) obtiveram idades $\mathrm{Rb}-\mathrm{Sr}$ em biotita-hornblenda sienogranito porfirítico e biotita sienogranito em torno de $1358 \mathrm{Ma}$, com razão inicial ${ }^{87} \mathrm{Sr} /{ }^{86} \mathrm{Sr}$ de $0,703 \pm 0,009$ e Bettencourt et al. (1997, 1999a) obtiveram idades U-Pb em cristais de zircão nas mesmas amostras valores de $1346 \pm 5$ Ma e $1338 \pm 4$ Ma respectivamente. Santos et al. $(2002,2008)$ dataram cristais de zircão do biotita-hornblenda monzogranito da porção norte do batólito pelo método U-Pb SHRIMP e obtiveram a idade de $1339 \pm 7$ Ma. Queiroz (2009), obteve idades Pb-Pb (evaporação) em cristais de zircão de 5 fácies graníticas mapeadas na porção leste do batólito, apresentando valores entre $1350 \pm 2$ e $1348 \pm 3$ Ma. Scandolara (2006) obteve idades modelo $\mathrm{Sm}-\mathrm{Nd}_{(\mathrm{TDM})}$ de 1,63 a 1,75 com $\varepsilon N d$ entre 0,50 e $+0,75$, sugerindo uma fonte mantélica com pouca participação de fonte crustal.

\subsubsection{Formação Nova Floresta (FNF)}

Definida por Leal et al. (1978), essa unidade é composta por uma associação de sills de rochas máficas, constituídos por basaltos, diabásios, gabros, olivina gabros e gabros anortosíticos de composição toleítica (Romanini 2000), com cerca de $120 \mathrm{~m}$ de espessura, intercalados em arenitos arcosianos da Formação Palmeiral, que ocorrem na região da Serra dos Pacaás Novos (região central do Estado de Rondônia). Leal et al. (1978) obtiveram idades K-Ar para basaltos variando de $967 \pm 17$ a $1098 \pm 17$ Ma. Já, Tohver et al. (2002) obtiveram idades Ar-Ar para os basaltos da borda norte da Serra Pacaás Novos de $1062 \pm 3$ Ma e idade-modelo Sm-Nd $($ TDM) de 1567 Ma, enquanto os gabros da mesma localidade forneceram idade Ar-Ar de $1198 \pm 3$ a $1201 \pm 2$ Ma.

\subsubsection{Formação Palmeiral (FP)}

Denominada por Lobato et al. (1966) e atualizada por Souza et al. (1975) e por Bahia (1997), a Formação Palmeiral é constituída por ortoconglomerados, quartzo arenitos e arenitos arcosianos. Bahia (1997) individualizou seis litofácies: ortoconglomerado maciço ou com estratificação incipiente (na base da sequência), arenito com estratificação horizontal, arenito com estratificação cruzada acanalada, arenito com estratificação cruzada tabular, arenito com estratificação cruzada sigmoidal e arenito maciço (no topo da sequência). Segundo Bahia (1997), o ambiente deposicional da Formação Palmeiral é formado por sistema fluvial anastomosado proximal ou de leque fluvial, limitada a grabens pós deposicionais. Informações geocronológicas U-Pb SHRIMP em zircões detríticos, obtidas por Santos et al. (2001), revelam idades máximas de sedimentação entre 1030 e 1154 Ma, na região da vila Palmeiral.

\subsubsection{Suíte Intrusiva Santa Clara (SISC)}

A primeira descrição dos granitos desta suíte foi feita por Kloosterman (1968) que as incluiu nos Younger Granites de Rondônia, enquanto Isotta et al. (1978) descrevem essas rochas como um corpo vulcano-plutônico de natureza rapakivítica, notadamente o Maciço Oriente Novo. A partir de dados geocronológicos, Bettencourt et al. (1997) agrupam na Suíte Intrusiva Santa Clara os maciços Santa Clara, Oriente Velho, Oriente Novo e Manteiga. No maciço principal (Oriente Novo) predomina biotita monzogranito porfirítico, de granulação fina a média, circundado por biotita sienogranito porfirítico, localmente com textura piterlítica. Sienogranitos porfiríticos e monzogranitos finos constituem pequenos corpos alongados na borda oeste do maciço. Outros corpos menores ocorrem na porção centro-oeste, representados por álcali-feldspato granito e riolito. Álcali-feldspato traquitos, albita leucogranitos, microsienitos e, mais raramente, aplitos e pegmatitos ocorrem no interior do maciço.

Os granitos dessa suíte apresentam diferentes estilos de mineralizações de cassiterita e elementos associados: stockwork em greisens, lodes de quartzo-cassiterita e quartzo-cassiterita- 
wolframita, veios de quartzo-topázio-fluorita, pegmatitos com albita, microclínio, berílio, topázio, molibdenita e cassiterita, controlados por um regime tectônico de caráter rúptil.

Dados geoquímicos mostram que as rochas da Suíte Intrusiva Santa Clara apresentam caráter subalcalino a alcalino, de natureza metaluminosa à fracamente peraluminosa. Exibem alto conteúdo de $\mathrm{Zr}, \mathrm{Y}, \mathrm{Nb}, \mathrm{Rb}, \mathrm{F}$, ETR e elevadas razões $\mathrm{K}_{2} \mathrm{O} / \mathrm{Na}_{2} \mathrm{O}, \mathrm{FeO} / \mathrm{MgO}$ e $\mathrm{Ga} / \mathrm{Al}$, compatíveis com granitos intraplaca do Tipo A, subtipo A2 (Bettencourt et al. 1999a, Quadros 2007, Quadros 2011). As rochas mais diferenciadas da suíte, tal como albita leucogranito, exibem padrão geoquímico diferenciado, com conteúdo muito elevado de $\mathrm{Li}$, $\mathrm{Rb}$ e $\mathrm{Sn}$.

Bettencourt et al. (1999a) apresentaram idades U-Pb em zircão para um quartzo monzonito do maciço Santa Clara, um hornblenda-biotita monzogranito do maciço Oriente Novo e um biotita sienogranito porfirítico do maciço Manteiga de $1081 \pm 50 \mathrm{Ma}, 1080 \pm 27 \mathrm{Ma}$ e $1082 \pm 5 \mathrm{Ma}$, respectivamente. Dados isotópicos obtidos pelo método $\mathrm{Rb}-\mathrm{Sr}$ definem idade isocrônica de $1052 \pm 21$ $\mathrm{Ma}$, com razão inicial ${ }^{87} \mathrm{Sr} /{ }^{86} \mathrm{Sr}$ de $0,710 \pm 0,008$ (Bettencourt et al. 1995). Quadros (2011) reinterpretam essas idades como a última geração de granitos pós orogênicos do sudoeste do Cráton Amazônico, relacionados a eventos magmáticos pós orogênicos (Orogenia Nova Brasilândia - 11801100 Ma), dentro da Província Sunsás.

\subsubsection{Suíte Intrusiva Rondônia (SIR) ou Granitos Jovens de Rondônia (Younger Granites)}

Sob a designação inicial de Younger Granites of Rondônia por Kloosterman (1968) que incluiu vários complexos graníticos de idades Meso a Neoproterozóico na porção centro-oriental de Rondônia. Bettencourt e Dall'Agnol (1987) mantiveram a definição de Kloosterman, mas englobaram nos Younger Granites somente os granitos com idades U-Pb em zircão entre 998 e 991 Ma, representados pelos maciços Ariquemes, Massangana, São Carlos, Caritianas, Pedra Branca, Santa Bárbara, Potosi e Jacundá. Bizzi et al. (2004) mantém o posicionamento cronoestratigráfico desta Suíte Estanífera do início do Neoproterozóico porém resgatam a denominação de Suíte Intrusiva Rondônia proposta por Isotta et al. (1978). São biotita monzogranitos e sienogranitos porfiríticos de granulação grossa (fase inicial, mais precoce), biotita sienogranitos e álcali-feldspato granitos porfiríticos (fase intermediária) e, albita granitos e quartzo-feldspato pórfiros (fase final, mais evoluída), estes últimos de ocorrência restrita e relacionados a mineralizações estaníferas.

Dados químicos definem os granitos dessa suíte como subalcalinos metaluminosos a fracamente peraluminosos, com exceção do albita granito que mostra caráter alcalino, possuem características semelhantes às dos granitos intraplaca do Tipo A, subtipo A2 (Bettencourt et al. 1999a).

Idades de cristalização U-Pb em zircão, para os granitos jovens, foram encontradas, as quais variam entre $998 \pm 5$ e $974 \pm 6 \mathrm{Ma}$ (Bettencourt et al. 1999a, Sparrenberg et al. 2002), sendo relacionados ao magmatismo Neoproterozóico anorogênico da porção sudoeste do Cráton Amazônico responsável pelas mais expressivas concentrações de $\mathrm{Sn}, \mathrm{W}, \mathrm{Nb}, \mathrm{Ta}, \mathrm{F}$, topázio e berilo da Província Estanífera de Rondônia (Priem et al. 1989, Bettencourt et al. 1999a). Bettencourt et al. (1999b) obtiveram idades-modelo $\mathrm{Sm}-\mathrm{Nd}_{(\mathrm{TDM})}$ entre 1,66 e 1,71 Ga e $\varepsilon \mathrm{Nd}$ entre $+0,33$ e $-3,25$, razão inicial de ${ }^{87} \mathrm{Sr} /{ }^{86} \mathrm{Sr}$ entre 0,707 e $0,709, \delta^{18} \mathrm{O}$ entre $+8,1$ e $+9,5 \%$, baixas razões ${ }^{206} \mathrm{~Pb} /{ }^{204} \mathrm{~Pb}(17,7$ a 20,6$)$ e ${ }^{208} \mathrm{~Pb} /{ }^{204} \mathrm{~Pb}(37,3$ e 43,2$)$.

\subsubsection{Coberturas Cenozóicas (CC)}

As Coberturas Cenozóicas de Rondônia compreendem depósitos terciários e quaternários continentais, de espessura em torno de $40 \mathrm{~m}$, controladas por fatores tectônicos, litológicos e climáticos. Os fatores tectônicos estão relacionados aos movimentos reflexos da Orogenia Andina (Costa et al. 1996). Nesta unidade estão incluídas lateritos imaturos desmantelados, camadas argiloarenosas com fragmentos subangulosos de laterito, bem como elúvio-colúvios imaturos, pouco 
espessos e compostos por areias mal selecionadas, siltes e argilas impregnadas com óxidos e hidróxidos de ferro. Scandolara et al. (1999) atribuem idade pliopleistocênica para essas coberturas e a interpretam como sendo coberturas de leques aluviais, canais fluviais, planícies de inundação e lacustres, constituídos de uma variedade de materiais que vão desde cascalhos até argilas lateritizadas. 


\section{CAPÍTULO 2}

\section{GEOLOGIA DO DEPÓSITO}

\subsection{APRESENTAÇÃO}

O contexto geológico da área estudada é representado por um batólito granítico com diferentes fácies petrográficas, denominado de Suíte Intrusiva Alto Candeias (SIAC; Bettencourt et al. 1997). Trata-se de um batólito alongado segundo a direção WNW-ESE, de cerca de $11.000 \mathrm{~km}^{2}$, intrusivo em rochas do Complexo Jamari e da Suíte Intrusiva Rio Crespo, na sua porção norte, enquanto que na porção sul, faz contato com rochas da Formação Nova Floresta e Palmeiral. A frente de lavra do depósito de estanho Liberdade está localizada na porção sul do batólito granítico, sudoeste da área estudada (Figura 2.1).

\subsection{PETROGRAFIA DA SIAC}

Na região do depósito de estanho Liberdade o batólito granítico tem três fácies petrográficas: biotita-hornblenda granito rapakivi (Fácies 1), hornblenda-biotita granito inequigranular médio (Fácies 2) e biotita granito inequigranular fino (Fácies 3), ilustrados na Figura 2.2. Esta última fácies ocorre apenas na frente de lavra e acompanha o trend dos veios de quartzo mineralizados a cassiterita. Entretanto, a distribuição lateral dessa fácies não foi possível de ser cartografada devido às limitações da área de exposição do mesmo (Figura 2.2C). Em geral, as diferentes rochas da SIAC são cortadas por fraturas de direção preferencial NW-SE e fraturas subordinadas NE-SW. Veios de quartzo mineralizados em cassiterita e arsenopirita preenchem essas fraturas.

A partir das relações de campo em conjunto com a descrição microscópica de seções polidas, foi possível fazer um estudo da composição modal e geoquímica das rochas encontradas na região do depósito de estanho Liberdade, os quais municiaram informações para a definição das três fácies graníticas, apresentados neste capítulo.

A nomenclatura adotada para as rochas estudadas baseou-se no diagrama modal QAP, construído com base em composições modais obtidas a partir da contagem de pontos em seções polidas (Streckeisen 1976, apud Le Maitre 1989). As três fácies caíram no campo dos monzogranitos (Figura 2.3). Já a abreviação do nome dos minerais nas figuras é baseada segundo Kretz (1983).

\subsubsection{Biotita-hornblenda granito rapakivi}

É o tipo petrográfico predominante na área em estudo (Figura 2.1), exibindo cor rosa, por vezes branco-esverdeada na porção mais alterada (greisenizada), textura porfirítica rapakivítica, ressaltada por fenocristais ovoides de K-feldspatos envoltos em plagioclásio de até $5 \mathrm{~cm}$ de comprimento (piterlitos), variando de 60 a $80 \%$ do volume da rocha e, imersos em uma matriz de granulação fanerítica média a grossa, composta por microclínio, oligoclásio, quartzo, hornblenda e biotita (Figura 2.4). Localmente, registra-se a presença de xenólitos graníticos granofíricos de granulação fina, além de veios de quartzo preenchendo fraturas que cortam o mesmo, por vezes, mineralizados.

Os fenocristais são de microclínio envoltos em oligoclásio (Figura 2.4B, 2.4C, 2.4D) e de oligoclásio, os quais são subédricos, se mostram micropertitizados, moderadamente sericitizados, pouco fraturados, exibem zoneamento oscilatório e geminações do tipo Carlsbad e Albita. 
Metalogênese do Depósito de Estanho Liberdade, Campo Novo de Rondônia - RO

Paulo Sérgio Mendes dos Santos Júnior

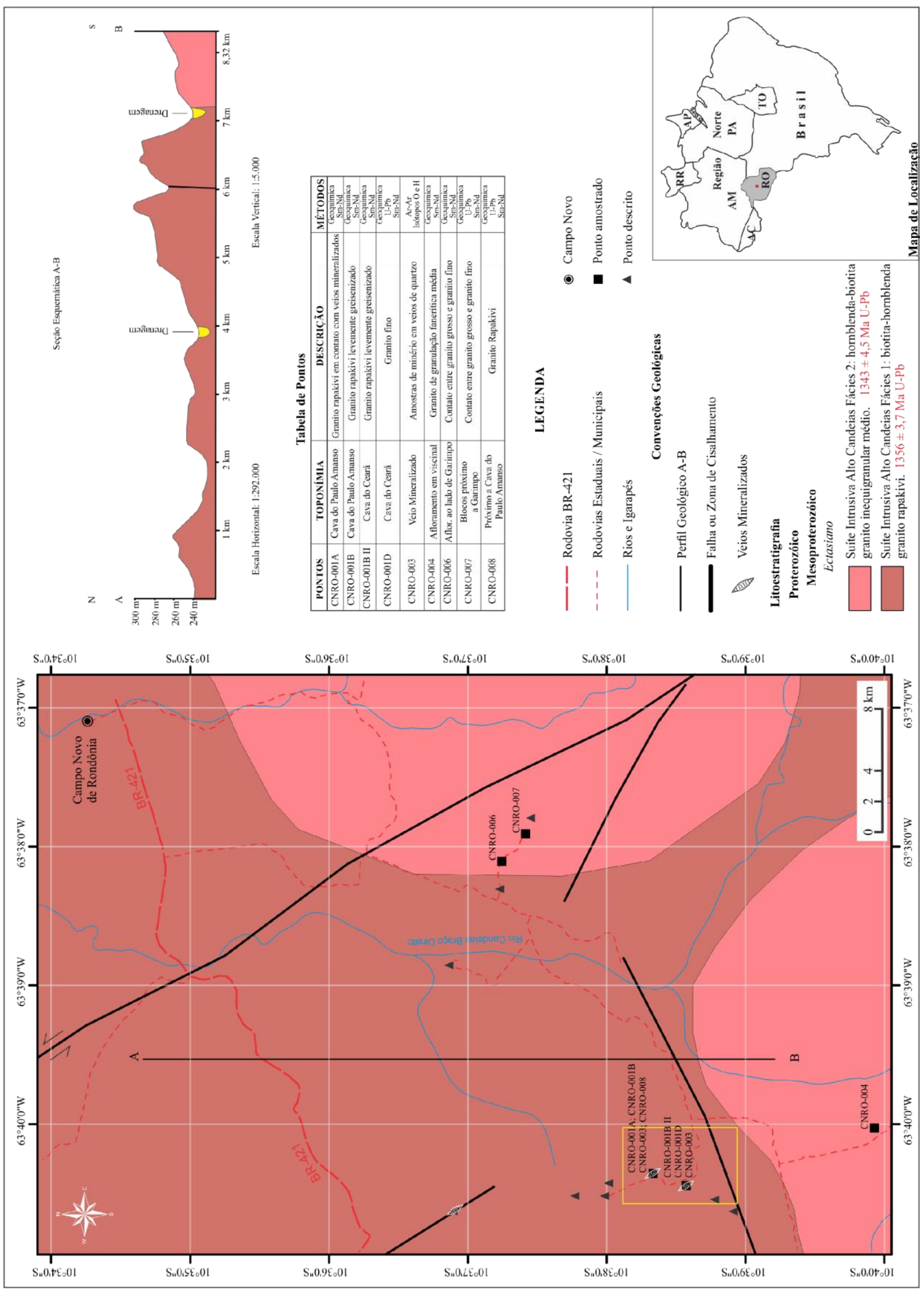

Figura 2.1. Mapa e perfil geológico da região do depósito de estanho Liberdade. O quadrado amarelo indica a área do depósito de estanho Liberdade. 

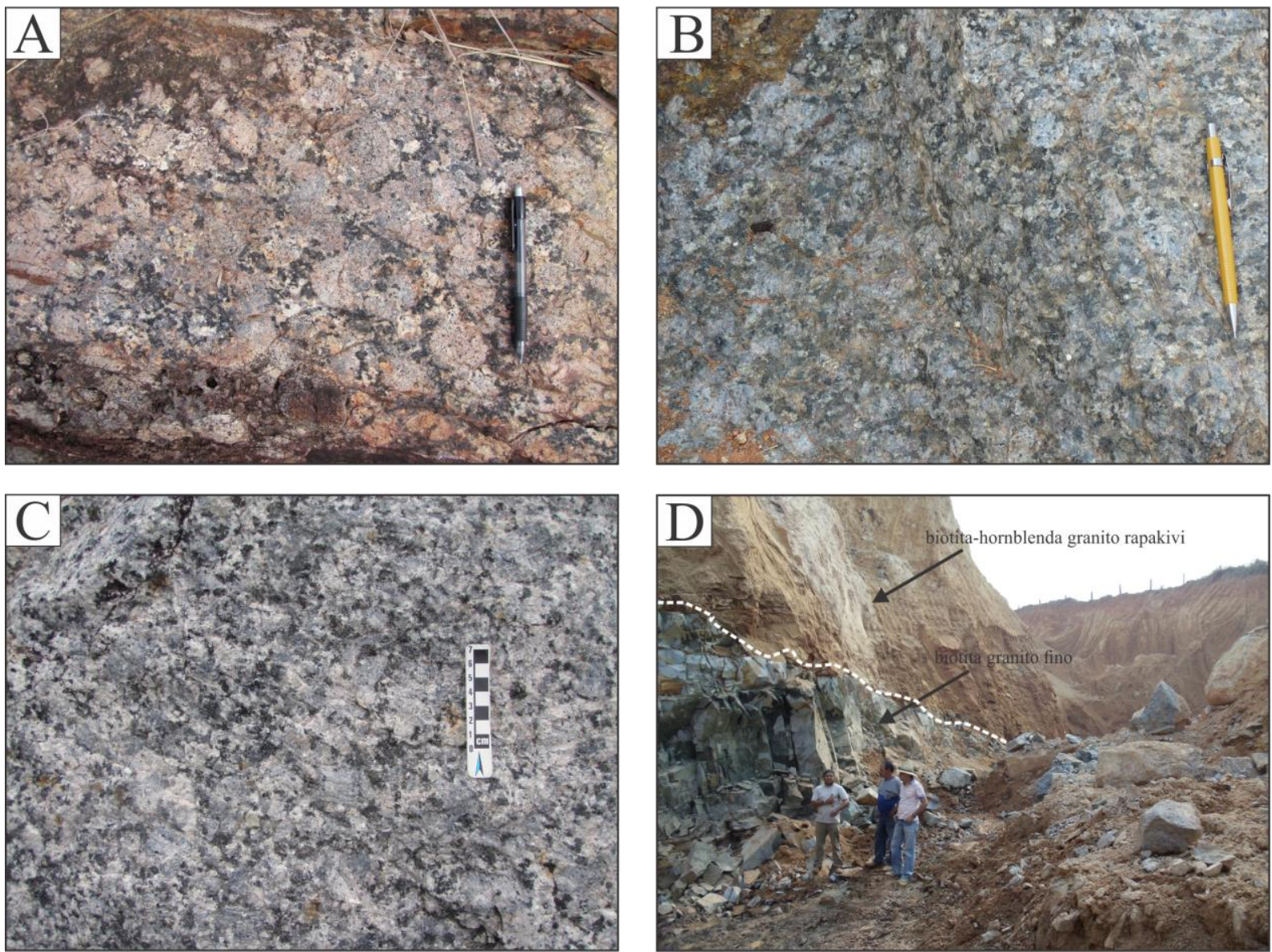

Figura 2.2. Fotografias de duas fácies de granitos da SIAC mapeados dentro da área do depósito de estanho Liberdade: A) biotita-hornblenda granito rapakivi; B) biotita-hornblenda granito levemente greisenizado; C) hornblenda-biotita granito inequigranular médio; D) contato entre o biotitahonblenda granito rapakivi saprolitizado e o biotita granito fino da frente de lavra.

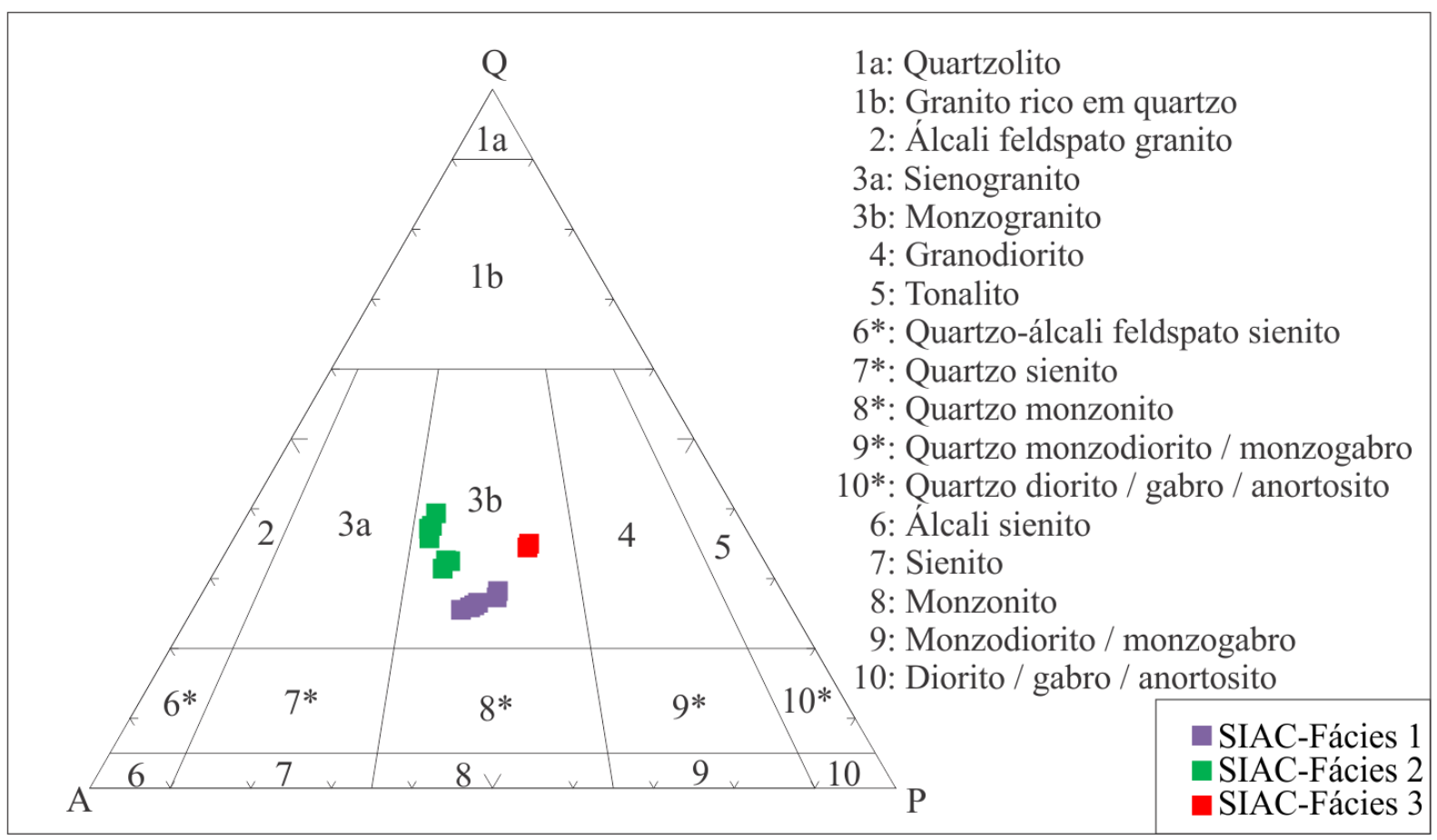

Figura 2.3. Diagrama QAP mostrando as amostras das três fácies graníticos da SIAC mapeados no depósito de estanho Liberdade, modificado de Streckeisen (1976, apud Le Maitre 1989). 

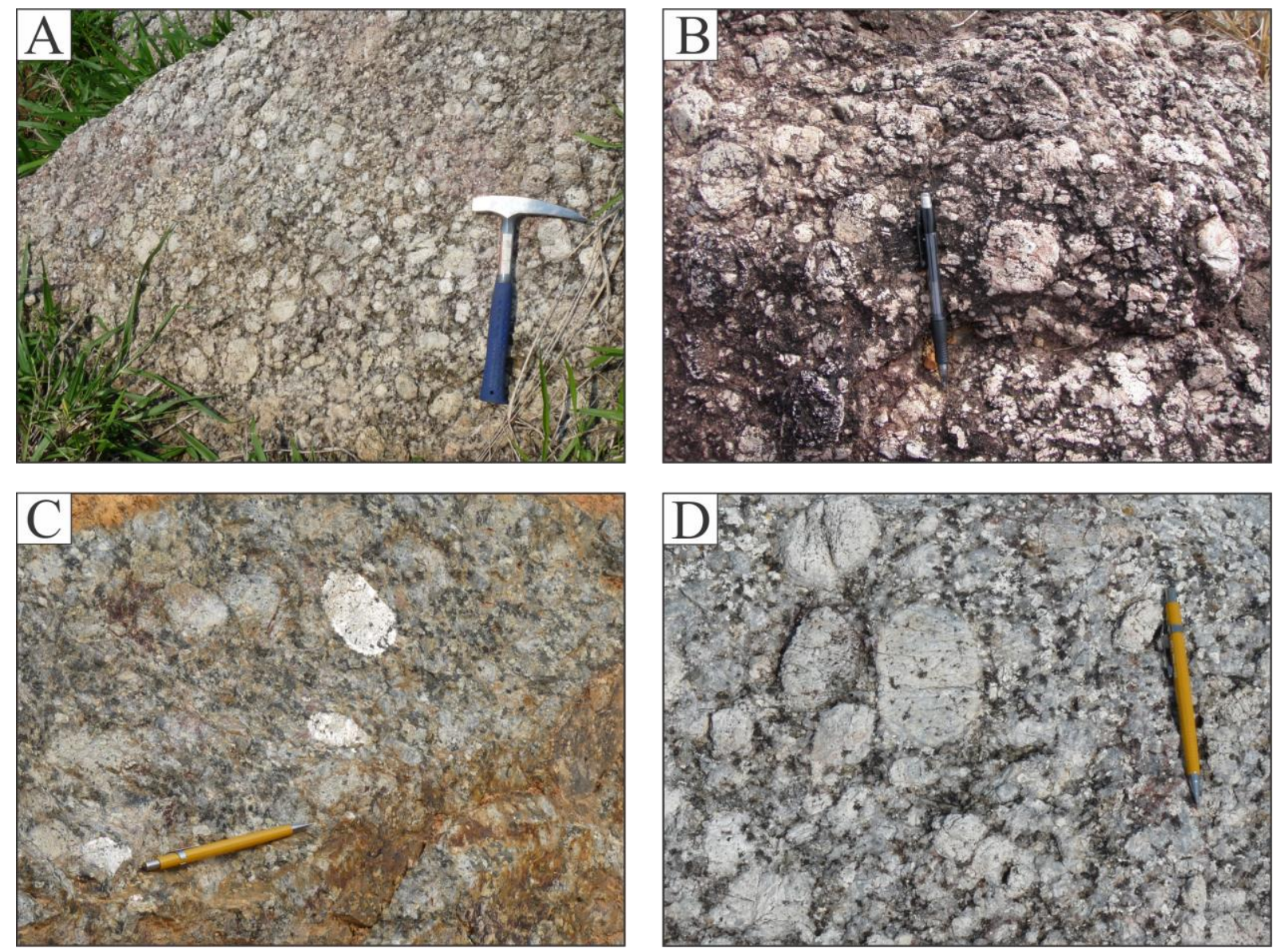

Figura 2.4. Aspectos texturais do biotita-hornblenda granito rapakivi (piterlitos), ressaltando sua granulação e os cristais de feldspatos zonados de tamanho centimétrico.

A matriz exibe textura inequigranular, é composta por K-feldspato (microclínio; 35-40\%), plagioclásio $\left(\mathrm{An}_{25-29}-30-35 \%\right)$, quartzo (25-30\%), hornblenda (5-10\%) e biotita (5-8\%), tendo como principais minerais acessórios ilmenita, apatita, monazita, zircão e pirita. Ocorrem ainda allanita, sericita, clorita, epidoto e grunnerita como minerais secundários, provavelmente associados aos processos hidrotermais tardi a pós magmáticos.

$\mathrm{Na}$ matriz, os feldspatos são dominantes (microclínio micropertitizado e oligoclásio) e, em geral, são euédricos a subédricos, se mostram parcialmente sericitizados, pouco fraturados e com planos de geminação bem definidos (Albita; Figura 2.5A). O quartzo ocorre distribuído de modo intersticial, sob a forma de cristais anédricos, extinção ondulante e pouco fraturado. Localmente, o quartzo ocorre incluso em cristais de microclínio e oligoclásio formando feições granofíricas (Figura 2.5B), as quais são produtos da cristalização simultânea a partir de misturas eutéticas ricas em voláteis, principalmente em áreas de baixa pressão, em condições epizonais (Hibbard 1979, Hughes 1982, Hibbard 1987). A hornblenda ocorre sob a forma de cristais subédricos, extinção inclinada e na sua zona de contato interage principalmente com o quartzo, plagioclásio e K-feldspato. Apresenta-se parcialmente desestabilizada para clorita e, localmente, ocorrem exsoluções de óxido de ferro sob seus cristais (Figura 2.5C). A grunnerita representa uma fase de reequilíbrio da hornblenda e é visualizada no contato com os feldspatos (Figura 2.5D, 2.5E). A biotita apresenta cristais subédricos parcialmente desestabilizados para clorita e faz contato, principalmente, com a hornblenda, quartzo e plagioclásio. Cristais intercrescidos de hornblenda sobre cristais de biotita também são visualizados (Figura 2.5F). 

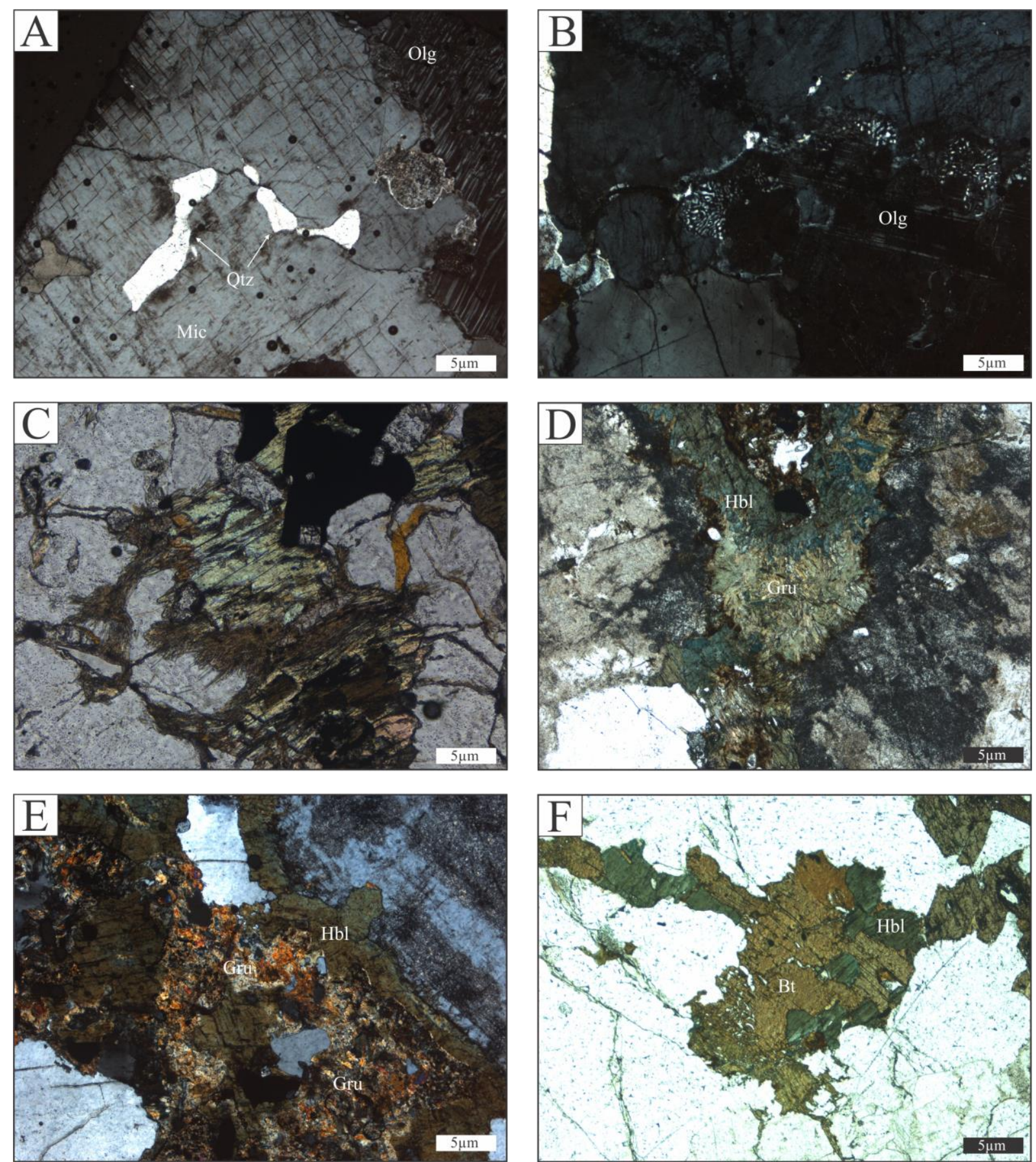

Figura 2.5. Fotomicrografias do biotita-hornblenda granito rapakivi: A) cristal de microclínio exibindo micro inclusões de quartzo e, cristal de oligoclásio exibindo feições pertíticas; B) cristal de oligoclásio exibindo feições granofíricas; C) cristal de hornblenda parcialmente cloritizada e com exsoluções de oxi-hidróxidos de ferro; D e E) reequilíbrio da hornblenda formando grunnerita; F) cristais de hornblenda intercrescidos em cristais de biotita. Siglas: Olg: oligoclásio; Qtz: quartzo; Mic: microclínio; Hbl: hornblenda; Gru: grunnerita; Bt: biotita.

\subsubsection{Hornblenda-biotita granito inequigranular médio}

Este tipo petrográfico ocorre nas porções leste, sul e sudoeste da área (Figura 2.1). Exibe cor cinza esbranquiçada, granulação fanerítica média a grossa inequigranular (Figura 2.6), está moderadamente fraturado e hospeda xenólitos do biotita-hornblenda granito rapakivi. É composto por quartzo (35-38\%), plagioclásio (oligoclásio; 25-30\%), K-feldspato (microclínio; 25-30\%), biotita (7- 
10\%) e hornblenda ( 5\%). Zircão, ilmenita e titanita são os principais minerais acessórios. Allanita, sericita, clorita e epidoto são os principais minerais secundários.
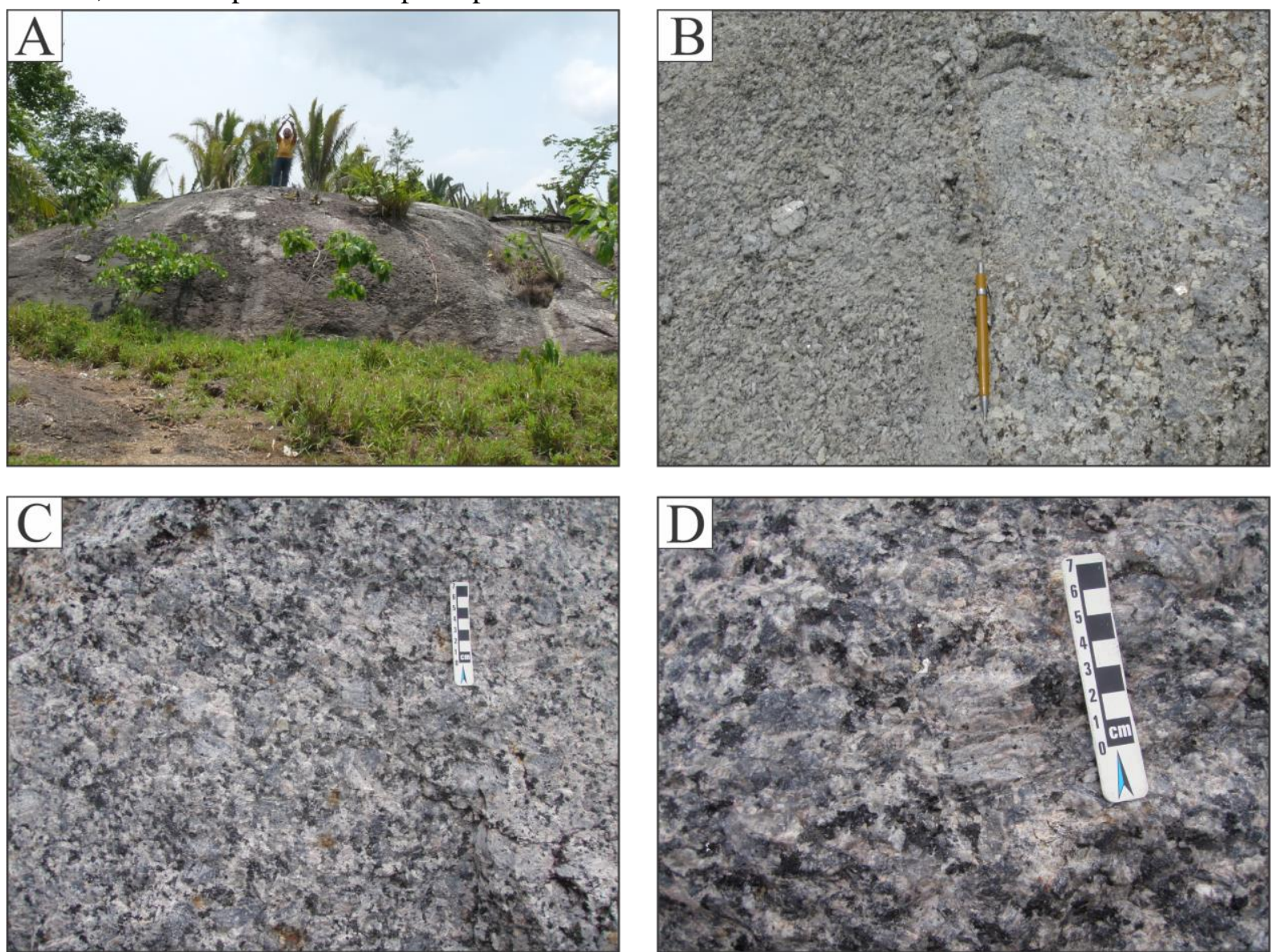

Figura 2.6. Aspectos texturais do hornblenda-biotita granito inequigranular médio: A) afloramento em forma de lajeiro do hornblenda-biotita granito inequigranular médio; B, C e D) arranjo textural fanerítico médio.

O quartzo ocorre distribuído de modo intersticial, sob a forma de cristais anédricos, extinção ondulante e pouco fraturado (Figura 2.7A). Localmente, o quartzo ocorre incluso em cristais de microclínio e oligoclásio formando feições granofíricas. O plagioclásio é do tipo oligoclásio $\left(\mathrm{An}_{26-29}\right)$, apresenta cristais subédricos exibindo geminação do tipo Albita, intercrescimento gráfico do tipo pertita e se mostram parcialmente sericitizados (Figura 2.7B, 2.7C). O K-feldspato é do tipo microclínio, apresenta cristais subédricos exibindo maclamento xadrez (Figura 2.7B) e, localmente, geminação do tipo Carlsbad, intercrescimento gráfico do tipo micropertita e se mostram moderadamente sericitizados. A biotita apresenta cristais alongados, subédricos, geralmente apresentando contatos serrilhados (figura 2.7D), moderadamente cloritizados, principalmente em seus planos de clivagem, e, localmente, exibem deformação do tipo kinks. A hornblenda ocorre sob a forma de cristais subédricos, extinção inclinada e na sua zona de contato interage principalmente com o quartzo, plagioclásio e K-feldspato. Apresenta-se parcialmente desestabilizada para clorita.

\subsubsection{Biotita granito inequigranular fino}

Esse tipo petrográfico ocorre encaixado na mesma estrutura do veio mineralizado, sempre em contato com o mesmo (Figuras 2.8, 2.9A 2.9B). Exibe cor cinza esverdeado, granulação fanerítica inequigranular fina (Figura 2.9C, 2.9D). É composto por quartzo (36-40\%), plagioclásio (oligoclásio; $\mathrm{An}_{26-28} ; 28-32 \%$ ), K-feldspato (microclínio; 25-28\%) e biotita (5-10\%). Apatita e zircão compõem a 
fase acessória. Sericita e clorita são os principais minerais secundários. Pequenos veios de composição quartzo-feldspática cortam a trama da rocha (Figura 2.9D).
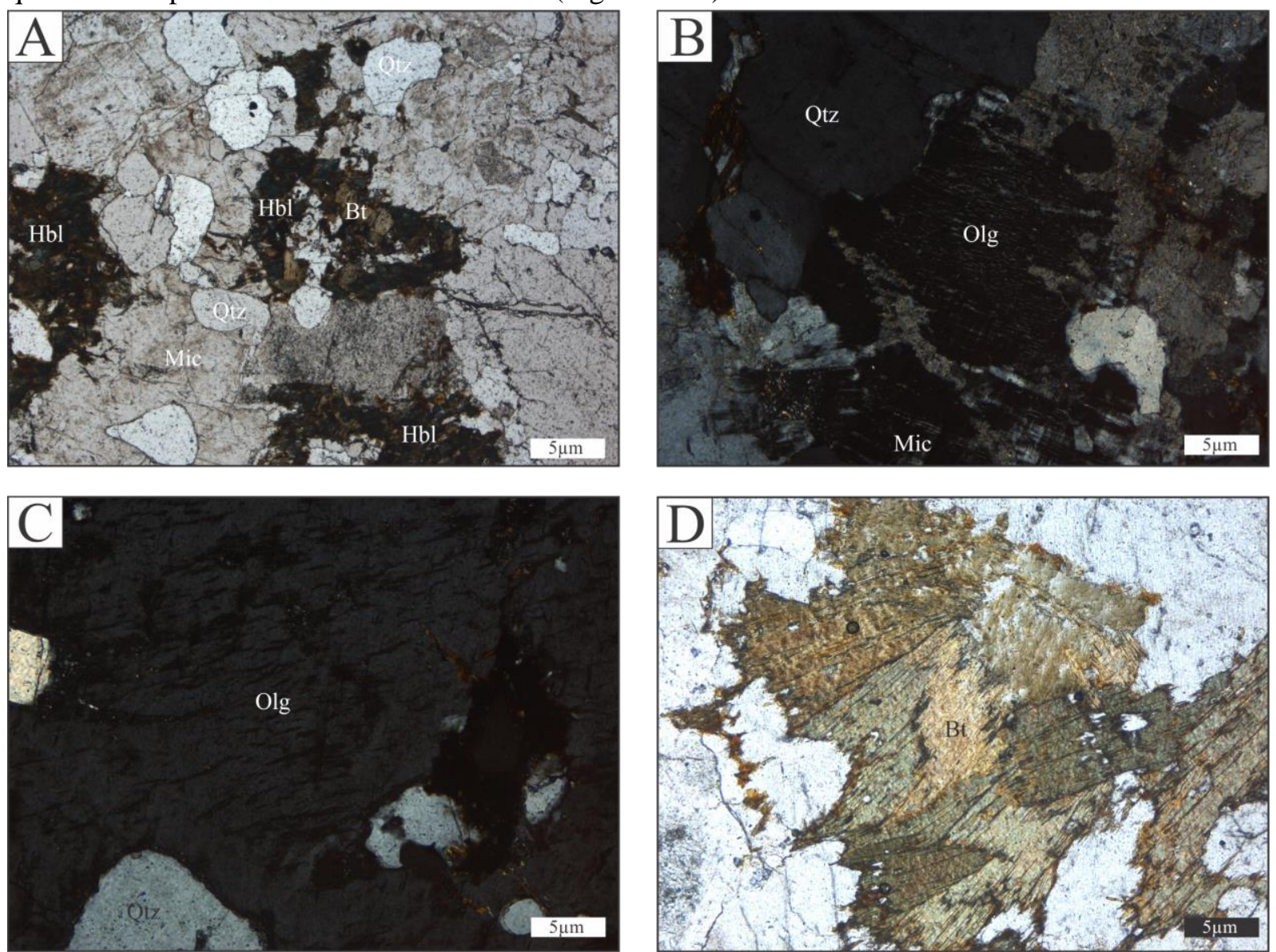

Figura 2.7. Fotomicrografias do hornblenda-biotita granito inequigranular médio: A) visão geral da trama do hornblenda-biotita granito; B) cristais de microclínio evidenciando seu maclamento típico e plagioclásio evidenciando seu intercrescimento gráfico; C) cristal de plagioclásio evidenciando seu intercrescimento gráfico; D) cristais de biotita parcialmente cloritizados e apresentando contatos serrilhados com os feldspatos. Siglas: Olg: oligoclásio; Qtz: quartzo; Mic: microclínio; Hbl: hornblenda; Bt: biotita.

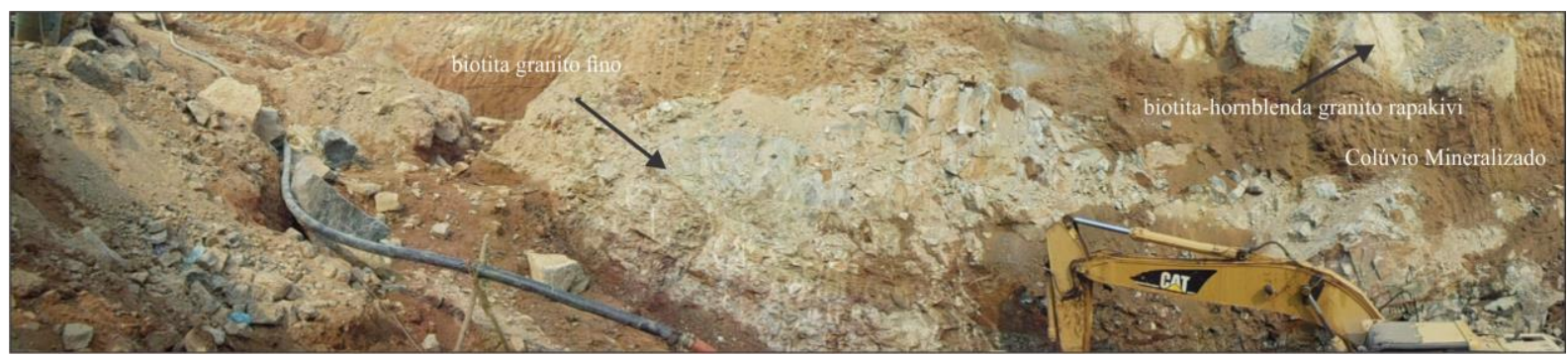

Figura 2.8. Fotografia panorâmica do biotita granito inequigranular fino visualizado dentro da frente de lavra de uma das cavas da Mina Liberdade e em contato com sedimentos inconsolidados por vezes mineralizados.

O quartzo ocorre sob a forma de cristais anédricos, com extinção levemente ondulante e pouco fraturados. O plagioclásio ocorre sob a forma de cristais subédricos moderadamente sericitizados, exibe geminação do tipo polissintética e intercrescimento mirmequítico sob as formas de barras e gotículas em contato com quartzo e K-feldspato. O K-feldspato é do tipo microclínio e ocorre sob a forma de cristais subédricos micropertíticos, exibe geminação do tipo Albita, maclamento xadrez e 
encontra-se moderadamente sericitizado. A biotita ocorre sob a forma de cristais alongados, subédricos e apresenta-se desestabilizada para clorita.
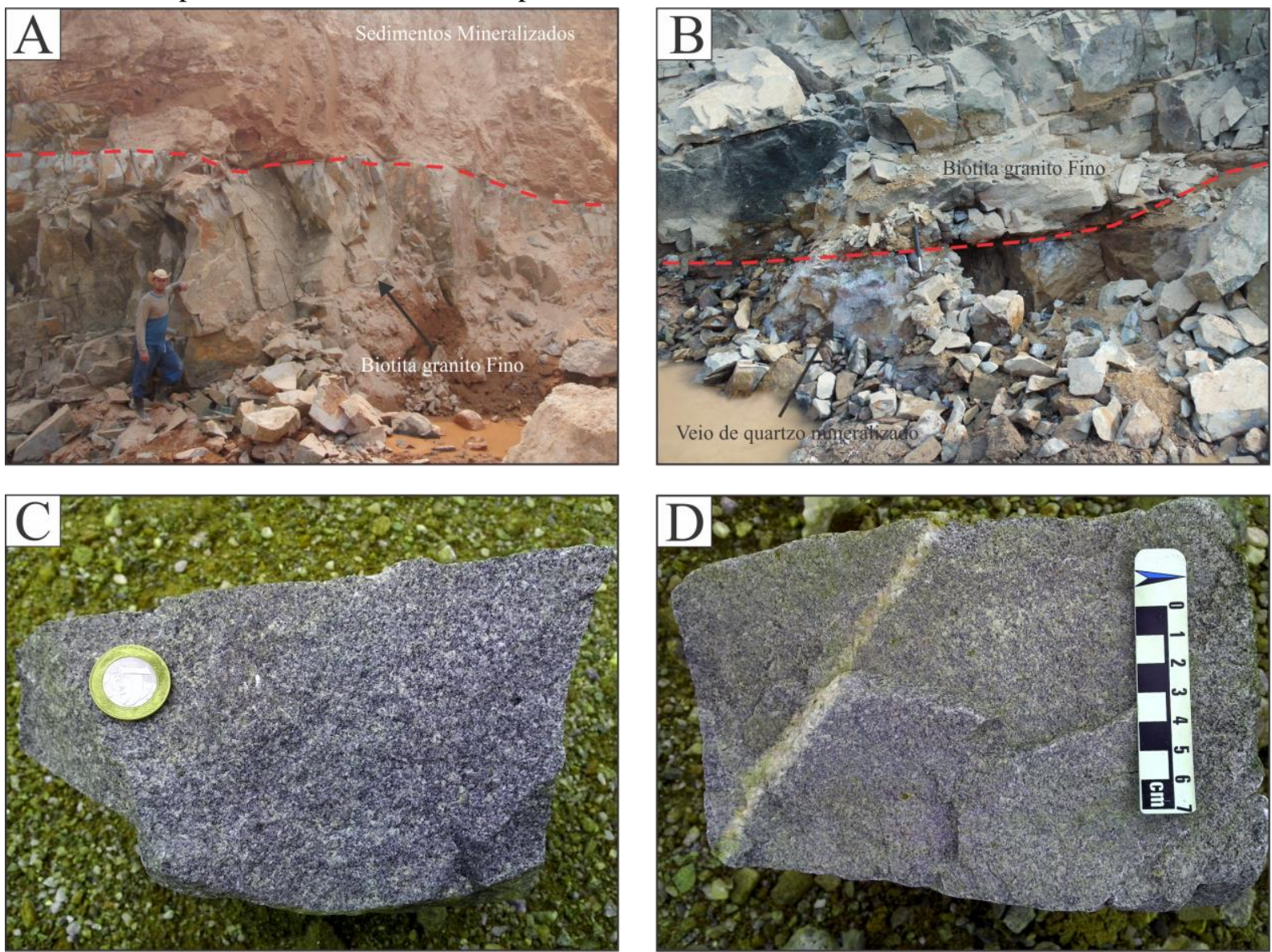

Figura 2.9. Fotografias do biotita granito inequigranular fino visualizado dentro da frente de lavra da Mina Liberdade: A e B) contato com sedimentos inconsolidados por vezes mineralizados e contato com o veio mineralizado, respectivamente; C) trama da rocha; D) veio quartzo-feldspático cortando a trama da rocha.

\subsection{GEOQUÍMICA DA SIAC}

As composições químicas das rochas graníticas da área de estudo serão apresentadas abaixo:

Foram analisadas 6 amostras do biotita-hornblenda granito rapakivi (Fácies 1), as quais revelaram concentrações de $\mathrm{SiO}_{2}=66,40$ a $67,57 \%, \mathrm{Al}_{2} \mathrm{O}_{3}=13,89$ a $14,63 \%, \mathrm{Fe}_{2} \mathrm{O}_{3}$ (total) $=5,31$ a 6,59 $\%, \mathrm{CaO}=2,18$ a 2,64 \%, $\mathrm{Na}_{2} \mathrm{O}=2,62$ a $2,78 \%, \mathrm{~K}_{2} \mathrm{O}=5,60$ a $6,10 \%, \mathrm{TiO}_{2} \sim 0,56 \%, \mathrm{MnO}, \mathrm{MgO}$ e $\mathrm{P}_{2} \mathrm{O}_{5} \leq 0,3 \%$ (Tabela 2.1), índice de saturação em alumina (ISA) metaluminoso e assinatura subalcalina $\left(\mathrm{K}_{2} \mathrm{O}+\mathrm{Na}_{2} \mathrm{O}=8,34\right.$ a 8,72 \%) de alto potássio (Figuras 2.10A, 2.10B, 2.10C). Em relação aos elementos traços apresenta teores acima de $1000 \mathrm{ppm}$ para o Ba, teores entre 500 e $1000 \mathrm{ppm}$ para o $\mathrm{Zr}$, teores entre 50-500 ppm para o $\mathrm{Rb}, \mathrm{Sr}$, Y e $\mathrm{Zn}$, e teores menores que $50 \mathrm{ppm}$ para o $\mathrm{Be}, \mathrm{Co}, \mathrm{Cs}$, $\mathrm{Ga}, \mathrm{Hf}, \mathrm{Nb}, \mathrm{Sc}, \mathrm{Sn}, \mathrm{Ta}, \mathrm{Th}, \mathrm{U}, \mathrm{W}, \mathrm{Cd}, \mathrm{Au}, \mathrm{As}, \mathrm{Cu}, \mathrm{Mo}$, Ni e Pb (Tabela 2.1). O padrão de distribuição dos elementos terras raras (ETR; Figura 2.11A), apresenta fraca anomalia negativa em Eu, com $\mathrm{Eu} / \mathrm{Eu}_{\mathrm{N}}=0,23$ a 0,53, moderado enriquecimento dos REE leves, de razão $[\mathrm{La} / \mathrm{Sm}]_{\mathrm{N}}=2,65$ a 3,08, em relação aos pesados, de razão $[\mathrm{Gd} / \mathrm{Yb}]_{\mathrm{N}}=1,61$ a 1,69 , o que indica um padrão de fracionamento moderado, de razão $[\mathrm{La} / \mathrm{Yb}]_{N}=6,1$ a 7,5. O padrão de distribuição dos elementos compatíveis e incompatíveis (Figura 2.11B), normalizados ao Manto Primordial de Wood et al. (1979), revela anomalias positivas em $\mathrm{Rb}, \mathrm{K}, \mathrm{La}, \mathrm{Nd}, \mathrm{Hf}, \mathrm{Zr}$, Sm e Tb e anomalias negativas em Th, U, Ta, Nb, Sr, P e Ti. 
Tabela 2.1. Resultados de análises químicas das fácies graníticas mapeadas da Suíte Intrusiva Alto Candeias.

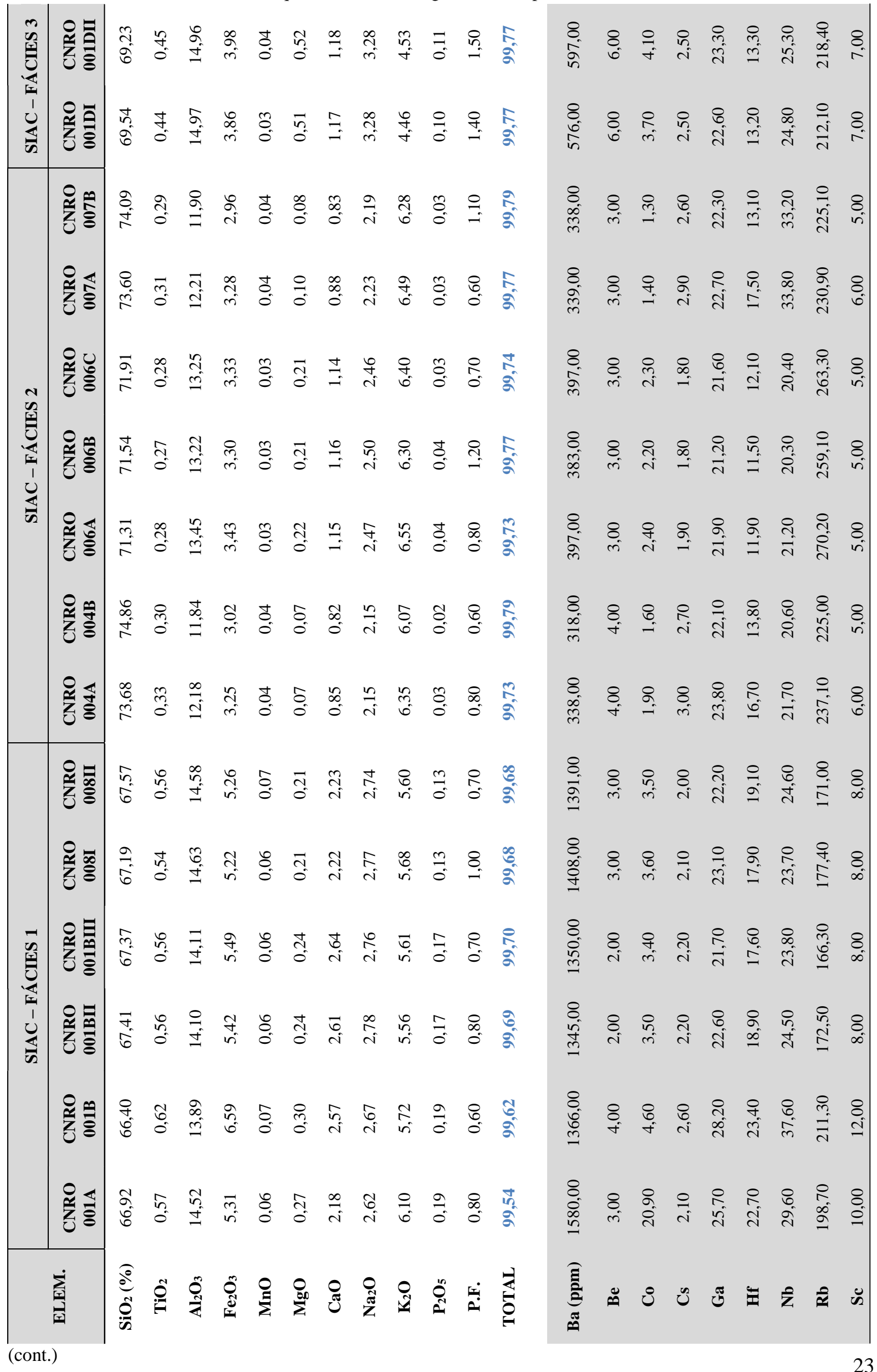


Metalogênese do Depósito de Estanho Liberdade, Campo Novo de Rondônia - RO

(cont.)

\begin{tabular}{|c|c|c|c|c|c|c|c|c|c|c|c|c|c|c|c|c|c|c|c|c|c|c|}
\hline \multirow[b]{2}{*}{ cont. } & \multirow[b]{2}{*}{ 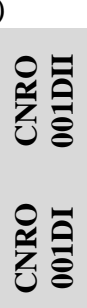 } & \multirow[b]{2}{*}{$\begin{array}{l}8 \\
i\end{array}$} & \multirow[b]{2}{*}{$\begin{array}{l}\text { त̂ } \\
\text { \&̊ }\end{array}$} & \multirow[b]{2}{*}{$\stackrel{n}{\sim}$} & \multirow[b]{2}{*}{$\begin{array}{l}\circ \\
n \\
n\end{array}$} & \multirow[b]{2}{*}{$\begin{array}{l}\stackrel{2}{0} \\
\stackrel{0}{0}\end{array}$} & \multirow[b]{2}{*}{$\begin{array}{l}\infty \\
\infty \\
i\end{array}$} & \multirow[b]{2}{*}{$\frac{8}{\pi}$} & \multirow[b]{2}{*}{ 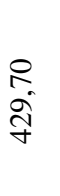 } & \multirow[b]{2}{*}{$\frac{0}{0}$} & \multirow[b]{2}{*}{$\stackrel{0}{=}$} & \multirow[b]{2}{*}{$\begin{array}{l}\infty \\
\infty \\
\dot{m}\end{array}$} & \multirow[b]{2}{*}{$\begin{array}{l}\text { तิ } \\
\text { ה }\end{array}$} & \multirow[b]{2}{*}{$\stackrel{\text { m}}{r}$} & \multirow[b]{2}{*}{$\underset{-}{8}$} & \multirow[b]{2}{*}{$\begin{array}{l}\stackrel{0}{0} \\
\stackrel{+}{d}\end{array}$} & \multirow[b]{2}{*}{$\begin{array}{l}8 \\
8 \\
8\end{array}$} & \multirow[b]{2}{*}{ 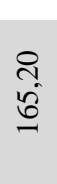 } & \multirow[b]{2}{*}{$\begin{array}{l}\text { o } \\
\infty \\
\infty \\
0 \\
\infty\end{array}$} & & & \\
\hline & & & & & & & & & & & & & & & & & & & & $\begin{array}{l}\text { ते } \\
\infty \\
\infty\end{array}$ & $\begin{array}{l}\infty \\
\infty \\
0 \\
\end{array}$ & $\frac{J_{i}}{\Delta}$ \\
\hline \multirow{7}{*}{ 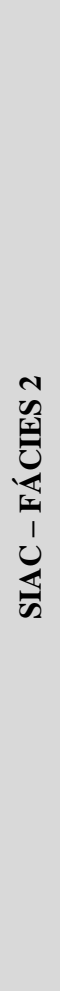 } & 魚 & $\begin{array}{l}8 \\
+\end{array}$ & $\begin{array}{l}\text { mे } \\
\text { oे }\end{array}$ & $\begin{array}{l}0 \\
\text { i }\end{array}$ & $\frac{i}{n}$ & ల్లి & $\stackrel{9}{=}$ & $\begin{array}{l}8 \\
i \\
\infty\end{array}$ & $\frac{\Re}{n}$ & $\frac{0}{0}$ & ڤ̊n & $\begin{array}{l}\text { ิㅗ } \\
=\end{array}$ & $\begin{array}{l}\text { तે } \\
\text { i }\end{array}$ & $\frac{\Re}{m}$ & $\stackrel{R}{=}$ & $\begin{array}{l}\stackrel{i}{+} \\
\text { ri }\end{array}$ & $\begin{array}{l}8 \\
\text { ச }\end{array}$ & 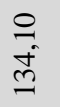 & $\begin{array}{l}0 \\
\text { ลิ } \\
\text { ㄱ. }\end{array}$ & $\hat{n}$ & $\begin{array}{l}\stackrel{8}{0} \\
\text { తి }\end{array}$ & $\frac{\hat{\sigma}}{\vec{v}}$ \\
\hline & 旁氐冬 & $\begin{array}{l}8 \\
+\end{array}$ & $\frac{0}{i n}$ & $\stackrel{8}{\rightarrow}$ & $\begin{array}{l}\text { m. } \\
\text { in }\end{array}$ & $\frac{8}{\circ}$ & તิ & $\begin{array}{l}\text { a } \\
\text { న }\end{array}$ & $\begin{array}{l}\text { ลे } \\
\text { กิ }\end{array}$ & $\frac{0}{0}$ & $\begin{array}{l}n \\
0 \\
0\end{array}$ & $\begin{array}{l}\stackrel{8}{0} \\
\stackrel{2}{2}\end{array}$ & $\begin{array}{l}\infty \\
\infty \\
\text { in }\end{array}$ & 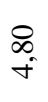 & $\stackrel{R}{=}$ & กิ & $\begin{array}{l}8 \\
\infty \\
\infty\end{array}$ & $\begin{array}{l}8 \\
n \\
n \\
n\end{array}$ & $\begin{array}{l}\stackrel{8}{\circ} \\
\infty \\
\text { के }\end{array}$ & $\stackrel{n}{n}$ & $\begin{array}{l}\text { กิ } \\
\text { రీ } \\
\text { t }\end{array}$ & ்ָ \\
\hline & 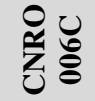 & $\begin{array}{l}8 \\
\text { mi }\end{array}$ & $\begin{array}{l}8 \\
8\end{array}$ & $\frac{\stackrel{2}{0}}{0}$ & $\begin{array}{l}\infty \\
\stackrel{\infty}{0} \\
=\end{array}$ & $\begin{array}{l}\Re \\
\text { ㄱ }\end{array}$ & $\begin{array}{l}0 \\
0 \\
0\end{array}$ & $\begin{array}{l}80 \\
\text { ஜ̊ }\end{array}$ & $\frac{\stackrel{n}{n}}{m}$ & $\frac{0}{0}$ & $\begin{array}{l}0 \\
0 \\
0\end{array}$ & 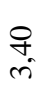 & ণ্ & $\begin{array}{l}\text { in } \\
\text { in }\end{array}$ & $\stackrel{9}{\rightrightarrows}$ & $\begin{array}{l}\text { ̊. } \\
\text { రీ }\end{array}$ & $\begin{array}{l}8 \\
i \\
\infty\end{array}$ & $\begin{array}{l}\stackrel{9}{+} \\
\text { ळે } \\
\text { הे }\end{array}$ & $\frac{\text { i }}{i}$ & $\begin{array}{l}\infty \\
0 \\
\dot{1}\end{array}$ & $\begin{array}{l}\stackrel{0}{2} \\
\stackrel{2}{-}\end{array}$ & $\frac{\infty}{0}$ \\
\hline & 㐘 & $\begin{array}{l}8 \\
\text { m }\end{array}$ & $\stackrel{\infty}{\infty}$ & $\begin{array}{l}\infty \\
\infty \\
0\end{array}$ & $\begin{array}{l}8 \\
\pm \\
=\end{array}$ & $\stackrel{\overbrace{}}{0}$ & $\frac{R}{0}$ & $\begin{array}{l}\stackrel{0}{5} \\
\text { 음 }\end{array}$ & $\begin{array}{l}\stackrel{9}{+} \\
\text { nn } \\
\text { ñ }\end{array}$ & $\frac{0}{0}$ & $\begin{array}{l}n \\
0 \\
0\end{array}$ & 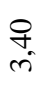 & $\begin{array}{l}\infty \\
\infty \\
i\end{array}$ & $\begin{array}{l}\infty \\
\text { in }\end{array}$ & $\stackrel{9}{\rightarrow}$ & $\underset{\substack{0 \\
\infty \\
\infty}}{\infty}$ & $\begin{array}{l}8 \\
\dot{+}\end{array}$ & $\begin{array}{l}\stackrel{P}{n} \\
\stackrel{n}{7}\end{array}$ & $\begin{array}{l}q \\
i n \\
i n\end{array}$ & $\begin{array}{l}\hat{\infty} \\
i n \\
i n\end{array}$ & $\begin{array}{l}\text { तิ } \\
\text { ปే }\end{array}$ & $\begin{array}{l}\text { ते } \\
\text { ô }\end{array}$ \\
\hline & 魚 & $\begin{array}{l}8 \\
\stackrel{+}{*}\end{array}$ & $\begin{array}{l}\text { q } \\
\text { i }\end{array}$ & $\begin{array}{l}\infty \\
\infty \\
0\end{array}$ & $\begin{array}{l}\text { กิ } \\
\text { I }\end{array}$ & $\begin{array}{l}\stackrel{n}{n} \\
\infty\end{array}$ & $\begin{array}{l}\stackrel{n}{n} \\
0\end{array}$ & $\begin{array}{l}\infty \\
\pm \\
\pm\end{array}$ & $\begin{array}{l}\infty \\
\infty \\
\infty \\
\infty\end{array}$ & $\begin{array}{l}0 \\
0\end{array}$ & $\begin{array}{l}0 \\
0 \\
0\end{array}$ & \begin{tabular}{l}
$\stackrel{\text { กิ }}{\forall}$ \\
\multirow{\forall}{*}{}
\end{tabular} & $\stackrel{8}{\circ}$ & $\begin{array}{l}\stackrel{n}{n} \\
6\end{array}$ & $\begin{array}{l}8 \\
\text { i }\end{array}$ & $\begin{array}{l}\text { i } \\
\text { in }\end{array}$ & $\begin{array}{l}8 \\
\infty \\
\infty\end{array}$ & $\begin{array}{l}\infty \\
m \\
\infty \\
\infty\end{array}$ & $\begin{array}{l}\text { त̂ } \\
\text { \& } \\
\text { in }\end{array}$ & $\begin{array}{l}\hat{a} \\
\text { in }\end{array}$ & 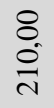 & $\begin{array}{l}\text { ते } \\
\text { ñ }\end{array}$ \\
\hline & 芫 & $\underset{-}{8}$ & $\begin{array}{l}\text { ஓे } \\
\text { fे }\end{array}$ & $\stackrel{f}{\rightarrow}$ & $\begin{array}{l}8 \\
\dot{m}\end{array}$ & ஜ̊ & શิ & $\begin{array}{l}8 \\
0 \\
0 \\
0\end{array}$ & $\frac{n}{n}$ & 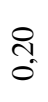 & $\begin{array}{l}\stackrel{n}{n} \\
0\end{array}$ & $\begin{array}{l}\text { సิ } \\
\text { さ̇ }\end{array}$ & 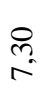 & $\begin{array}{l}\stackrel{q}{+} \\
i\end{array}$ & $\stackrel{\text { શิ }}{-}$ & $\begin{array}{l}\text { 8. } \\
\text { in }\end{array}$ & $\begin{array}{l}8 \\
8 \\
8\end{array}$ & $\begin{array}{l}i \\
\infty \\
\infty \\
\infty\end{array}$ & $\begin{array}{l}8 \\
8 \\
\infty \\
\infty \\
m\end{array}$ & $\begin{array}{l}\tilde{\sigma} \\
\stackrel{\sigma}{\sigma}\end{array}$ & $\frac{8}{\infty}$ & $\frac{\bar{\sigma}}{\bar{m}}$ \\
\hline & 兄 & $\begin{array}{l}8 \\
\text { m }\end{array}$ & \begin{tabular}{l}
$\stackrel{8}{n}$ \\
\multirow{f}{f}{}
\end{tabular} & $\stackrel{\overbrace{}}{-}$ & $\begin{array}{l}0 \\
\frac{0}{n}\end{array}$ & $\stackrel{\circ}{\sim}$ & $\stackrel{\text { ్ }}{-}$ & $\begin{array}{l}\text { g+ } \\
\text { g̊ }\end{array}$ & $\begin{array}{l}\stackrel{\Omega}{\Omega} \\
\text { đู }\end{array}$ & ๙ิ & ڤ̊n & $\begin{array}{l}8 \\
0\end{array}$ & $\begin{array}{l}\text { ते } \\
\stackrel{2}{n}\end{array}$ & 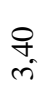 & $\stackrel{f}{\rightarrow}$ & 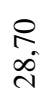 & $\begin{array}{l}8 \\
8 \\
8\end{array}$ & $\begin{array}{l}8 \\
\text { ì }\end{array}$ & \begin{tabular}{l}
$\stackrel{n}{2}$ \\
\multirow{2}{*}{}
\end{tabular} & $\begin{array}{l}\text { ป } \\
\text { in }\end{array}$ & ஃू & $\begin{array}{l}\text { nे } \\
\text { ñ }\end{array}$ \\
\hline \multirow{6}{*}{ 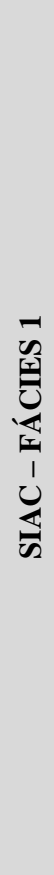 } & 을 & $\begin{array}{l}8 \\
\text { m }\end{array}$ & $\begin{array}{l}\stackrel{2}{尺} \\
\infty \\
\infty\end{array}$ & $\stackrel{8}{\mathscr{8}}$ & $\begin{array}{l}\stackrel{n}{2} \\
\pm\end{array}$ & $\begin{array}{l}8 \\
\text { mi }\end{array}$ & $\stackrel{0}{=}$ & $\begin{array}{l}8 \\
\infty \\
\infty\end{array}$ & $\begin{array}{l}\infty \\
i n \\
6\end{array}$ & તิ & $\begin{array}{l}8 \\
0 \\
0\end{array}$ & $\frac{O}{f}$ & $\begin{array}{l}\stackrel{n}{7} \\
+\end{array}$ & $\underset{-}{8}$ & $\begin{array}{l}\infty \\
0 \\
0\end{array}$ & $\begin{array}{l}8 \\
\text { å }\end{array}$ & $\begin{array}{l}8 \\
8 \\
2\end{array}$ & $\begin{array}{l}\text { ๙े } \\
\text { กे }\end{array}$ & $\begin{array}{l}\text { ని } \\
\infty \\
\infty\end{array}$ & $\overrightarrow{\mathrm{N}}$ & $\frac{8}{\infty}$ & बَ \\
\hline & そֶׁ & $\begin{array}{l}8 \\
i\end{array}$ & $\begin{array}{l}\stackrel{9}{+} \\
\dot{\infty}\end{array}$ & $\stackrel{f}{\rightarrow}$ & $\begin{array}{l}\stackrel{尺}{ \pm} \\
\underset{ \pm}{+}\end{array}$ & $\stackrel{\circ}{n}$ & ్ㅗ & $\begin{array}{l}\text { হి. } \\
\text { ô }\end{array}$ & 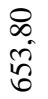 & $\stackrel{0}{0}$ & $\stackrel{0}{=}$ & $\begin{array}{l}\stackrel{f}{+} \\
\text { t }\end{array}$ & $\begin{array}{l}\stackrel{\text { g }}{+} \\
\dot{+}\end{array}$ & ̊̊. & $\frac{R}{0}$ & $\begin{array}{l}\text { గn } \\
\text { å }\end{array}$ & $\begin{array}{l}8 \\
\circ \\
2\end{array}$ & $\begin{array}{l}\text { m. } \\
\text { ஸे }\end{array}$ & $\begin{array}{l}\infty \\
- \\
-\end{array}$ & $\begin{array}{l}\text { مे } \\
\text { ते }\end{array}$ & $\begin{array}{l}\stackrel{2}{2} \\
\infty \\
\infty\end{array}$ & $\begin{array}{l}\text { ¿ } \\
\stackrel{-}{-}\end{array}$ \\
\hline & 谣青 & $\begin{array}{l}8 \\
i\end{array}$ & $\frac{n}{\infty}$ & $\stackrel{\stackrel{f}{q}}{-}$ & $\begin{array}{l}\stackrel{n}{n} \\
\varrho\end{array}$ & $\begin{array}{l}\text { ஸे } \\
\text { ஸे }\end{array}$ & $\stackrel{0}{=}$ & $\begin{array}{l}\text { q } \\
\stackrel{2}{r}\end{array}$ & $\begin{array}{l}\mathscr{\Omega} \\
\text { nิ }\end{array}$ & ત્ & $\stackrel{\text { లి }}{-}$ & $\frac{0}{m}$ & $\underset{f}{\stackrel{P}{r}}$ & $\frac{0}{m}$ & $\underset{-}{8}$ & $\begin{array}{l}\text { ㅇ. } \\
\text { an }\end{array}$ & $\begin{array}{l}8 \\
\infty \\
\infty\end{array}$ & $\begin{array}{l}\infty \\
0 \\
0\end{array}$ & $\begin{array}{l}8 \\
80\end{array}$ & 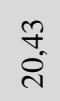 & $\frac{?}{\infty}$ & 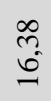 \\
\hline & 旁青 & $\begin{array}{l}8 \\
\text { i }\end{array}$ & $\begin{array}{l}\infty \\
\infty \\
\infty\end{array}$ & $\underset{\sim}{\stackrel{9}{+}}$ & $\begin{array}{l}\text { n. } \\
\stackrel{0}{0}\end{array}$ & $\begin{array}{l}\text { ते } \\
\text { m. }\end{array}$ & $\underset{\sim}{\stackrel{9}{*}}$ & 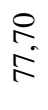 & 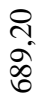 & 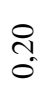 & $\begin{array}{l}\stackrel{+}{+} \\
\text { i }\end{array}$ & ๙ે & 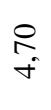 & $\stackrel{\circ}{\stackrel{0}{m}}$ & $\begin{array}{l}\infty \\
\infty \\
0\end{array}$ & $\begin{array}{l}8 \\
\circ\end{array}$ & $\begin{array}{l}8 \\
\infty \\
\infty\end{array}$ & $\begin{array}{l}8 \\
\stackrel{2}{2}\end{array}$ & $\begin{array}{l}\text { 운 } \\
\text { in }\end{array}$ & $\frac{\text { तิ }}{\text { ते }}$ & $\begin{array}{l}\stackrel{0}{n} \\
\stackrel{0}{\infty}\end{array}$ & ర్ర \\
\hline & 釆 & $\begin{array}{l}8 \\
\stackrel{+}{*}\end{array}$ & $\begin{array}{l}\stackrel{\text { ñ }}{n} \\
\stackrel{n}{n}\end{array}$ & $\begin{array}{l}\text { re } \\
\text { i }\end{array}$ & $\begin{array}{l}n \\
n \\
n\end{array}$ & $\begin{array}{l}\stackrel{8}{8} \\
\stackrel{+}{*}\end{array}$ & $\stackrel{?}{\approx}$ & ஜn & $\begin{array}{l}\stackrel{\circ}{n} \\
\frac{0}{a}\end{array}$ & $\stackrel{0}{0}$ & $\begin{array}{l}\infty \\
\infty \\
0\end{array}$ & $\begin{array}{l}\stackrel{n}{n} \\
\text { in }\end{array}$ & ๙઼ & $\begin{array}{l}8 \\
\text { i }\end{array}$ & 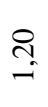 & $\frac{0}{\stackrel{0}{m}}$ & $\begin{array}{l}8 \\
\text { î }\end{array}$ & $\begin{array}{l}8 \\
\pm \\
=\end{array}$ & $\begin{array}{l}\text { D } \\
\text { లె } \\
\text { ते }\end{array}$ & $\stackrel{\tilde{F}}{\tilde{m}}$ & $\begin{array}{l}8 \\
\text { ले }\end{array}$ & $\begin{array}{l}\overline{0} \\
\bar{N}\end{array}$ \\
\hline & 孚 & $\begin{array}{l}8 \\
\text { m. }\end{array}$ & $\begin{array}{l}0 \\
\stackrel{0}{0}\end{array}$ & $\stackrel{\infty}{\infty}$ & $\begin{array}{l}8 \\
\stackrel{2}{n}\end{array}$ & $\begin{array}{l}8 \\
\stackrel{0}{+}\end{array}$ & $\stackrel{\stackrel{P}{+}}{\rightarrow}$ & $\begin{array}{l}0 \\
\infty \\
=\end{array}$ & $\begin{array}{l}8 \\
2 \\
2\end{array}$ & @) & $\begin{array}{l}\stackrel{8}{0} \\
0\end{array}$ & $\begin{array}{l}\text { ले } \\
\text { in }\end{array}$ & $\stackrel{9}{+}$ & ๙े & $\begin{array}{l}\text { : } \\
\stackrel{0}{0}\end{array}$ & $\begin{array}{l}\stackrel{q}{+} \\
\stackrel{9}{-}\end{array}$ & $\begin{array}{l}8 \\
9 \\
=\end{array}$ & $\begin{array}{l}\text { +q } \\
\text { ó }\end{array}$ & 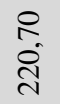 & $\frac{N}{\stackrel{\infty}{\sim}}$ & $\begin{array}{l}\infty \\
\infty \\
\infty \\
=\end{array}$ & \begin{tabular}{l}
$\infty$ \\
0 \\
\multirow{N}{*}{}
\end{tabular} \\
\hline & $\sum_{\text {족 }}^{\dot{\Delta}}$ & $\begin{array}{l}\widehat{\Xi} \\
\hat{\Xi} \\
\text { कै }\end{array}$ & $\dot{\Delta}$ & $\stackrel{\pi}{=}$ & $\stackrel{E}{F}$ & $D$ & 3 & $\nu$ & $\grave{N}$ & $\tilde{J}$ & 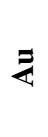 & $\sum_{1}^{\infty}$ & $\tilde{E}$ & $\stackrel{e}{\Sigma}$ & $\ddot{\mathbf{z}}$ & $\hat{a}$ & ธี & 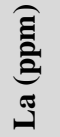 & ت & $\dot{E}$ & $\bar{z}$ & 跑 \\
\hline
\end{tabular}




\begin{tabular}{|c|c|c|c|c|c|c|c|c|c|c|c|c|c|c|}
\hline \multicolumn{15}{|c|}{ (cont.) } \\
\hline 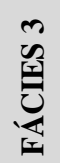 & $\begin{array}{l}\text { 을 } \\
\text { 学 }\end{array}$ & $\begin{array}{l}\infty \\
0 \\
0\end{array}$ & $\stackrel{\bigodot}{\stackrel{f}{f}}$ & $\stackrel{\infty}{m}$ & $\stackrel{ \pm}{\underline{\sigma}}$ & $\begin{array}{l}\infty \\
\infty \\
0 \\
0\end{array}$ & $\begin{array}{l}n \\
\sim \\
f\end{array}$ & $\begin{array}{l}\text { I } \\
\text { ô }\end{array}$ & $\hat{ర}$ & \begin{tabular}{l} 
సิ \\
\multirow{2}{a}{}
\end{tabular} & $\underset{r}{\mathbb{r}}$ & $\begin{array}{l}8 \\
\stackrel{n}{n} \\
i n\end{array}$ & बे & $\begin{array}{c}0 \\
\text { हn } \\
\text { n. } \\
\infty\end{array}$ \\
\hline 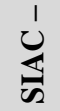 & 㐘完 & $\begin{array}{l}\infty \\
0 \\
0\end{array}$ & $\stackrel{\infty}{\stackrel{一}{m}}$ & $\underset{f}{f}$ & $\stackrel{ \pm}{\underline{\sigma}}$ & $\begin{array}{l}\overline{0} \\
\overline{=}\end{array}$ & $\stackrel{\stackrel{I}{*}}{\leftarrow}$ & $\begin{array}{l}\stackrel{2}{1} \\
\text { ô }\end{array}$ & nู & $\begin{array}{l}8 \\
\text { i } \\
\text { S. }\end{array}$ & $\underset{\sim}{\stackrel{f}{r}}$ & $\begin{array}{l}\infty \\
\dot{m} \\
\dot{n}\end{array}$ & $\begin{array}{l}\infty \\
\infty \\
i\end{array}$ & 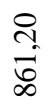 \\
\hline \multirow{7}{*}{ 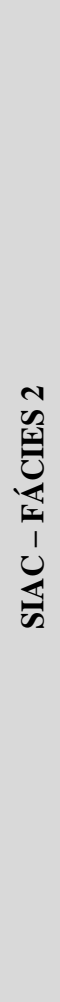 } & 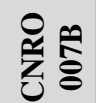 & ळু & $\vec{\sim}$ & $\underset{m}{8}$ & $\begin{array}{l}\text { ले } \\
\text { ॠ }\end{array}$ & $\begin{array}{l}8 \\
\text { in }\end{array}$ & $\stackrel{\vec{t}}{r}$ & $\stackrel{m}{0}$ & $\underset{r}{\stackrel{\Xi}{r}}$ & $\begin{array}{l}\infty \\
\infty \\
\infty \\
=\end{array}$ & $\stackrel{\infty}{\stackrel{\infty}{0}}$ & $\begin{array}{l}\text { ते } \\
\text { ๗ె} \\
\forall\end{array}$ & m. & $\begin{array}{l}\infty \\
\infty \\
n \\
\infty\end{array}$ \\
\hline & 䒘 & ڤू. & $\frac{\infty}{m}$ & $\hat{\hat{a}}$ & $\begin{array}{l}\infty \\
m \\
\stackrel{\Xi}{ \pm}\end{array}$ & $\begin{array}{l}n \\
i \\
n\end{array}$ & $\stackrel{f}{m}$ & $\stackrel{ \pm}{m}$ & $\underset{\sim}{+}$ & $\stackrel{?}{\stackrel{9}{-}}$ & $\stackrel{\cong}{=}$ & $\begin{array}{l}\text { q } \\
\text { هे } \\
\text { gे }\end{array}$ & $\begin{array}{l}\bar{n} \\
m\end{array}$ & $\begin{array}{l}n \\
\text { ñ. } \\
\text { है }\end{array}$ \\
\hline & 尝 & ڤ̆ & $\vec{m}$ & $\underset{\text { oे }}{\text { s. }}$ & $\begin{array}{l}8 \\
\stackrel{ \pm}{ \pm}\end{array}$ & $\begin{array}{c}5 \\
\text { in }\end{array}$ & $\begin{array}{l}\hat{n} \\
\text { m. }\end{array}$ & 3) & $\stackrel{\mathbb{N}}{\stackrel{N}{*}}$ & $\begin{array}{l}8 \\
\stackrel{\text { I }}{=}\end{array}$ & $\hat{\alpha}$ & 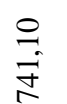 & $\stackrel{\infty}{\stackrel{\infty}{~}}$ & $\begin{array}{l}\text { तิ } \\
\text { ธิ }\end{array}$ \\
\hline & 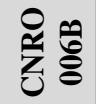 & s. & $\underset{i}{\stackrel{t}{i}}$ & $\underset{i}{\stackrel{8}{0}}$ & $\stackrel{\Re}{\stackrel{I}{I}}$ & $\begin{array}{l}\stackrel{n}{f} \\
F\end{array}$ & $\stackrel{8}{\infty}$ & $\begin{array}{l}\hat{y} \\
\hat{0}\end{array}$ & $\underset{r}{\mathbb{S}}$ & 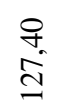 & $\hat{\alpha}$ & $\begin{array}{l}\circ \\
\stackrel{0}{\circ}\end{array}$ & $\stackrel{8}{\infty}$ & $\begin{array}{l}\text { तิ } \\
\text { ूू }\end{array}$ \\
\hline & 产 & ầ & $\stackrel{n}{\circ}$ & $\stackrel{n}{a}$ & $\begin{array}{l}\text { के } \\
\text { ल) }\end{array}$ & 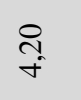 & $\begin{array}{l}0 \\
m \\
m\end{array}$ & $\begin{array}{l}\text { İ } \\
\text { ô }\end{array}$ & $\stackrel{\infty}{\sim}$ & $\begin{array}{l}8 \\
0 \\
0 \\
0\end{array}$ & $\begin{array}{l}\dot{H} \\
\stackrel{2}{0}\end{array}$ & $\begin{array}{l}8 \\
\infty \\
\infty \\
2\end{array}$ & $\stackrel{\infty}{\stackrel{\infty}{\infty}}$ & $\begin{array}{l}8 \\
\dot{d} \\
8\end{array}$ \\
\hline & 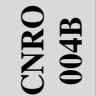 & à & $\stackrel{\vec{i}}{i}$ & $\underset{i}{\stackrel{i}{i}}$ & $\begin{array}{l}\stackrel{8}{0} \\
\stackrel{I}{I}\end{array}$ & $\stackrel{\vartheta}{\vec{f}}$ & $\stackrel{8}{\circ}$ & $\begin{array}{l}\hat{y} \\
\hat{0}\end{array}$ & 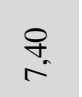 & $\begin{array}{l}8 \\
\stackrel{0}{0} \\
\stackrel{0}{0}\end{array}$ & $\underset{8}{8}$ & $\stackrel{0}{\Rightarrow}$ & $\stackrel{n}{n}$ & $\begin{array}{l}\text { श्. } \\
\text { हैं } \\
\text { है }\end{array}$ \\
\hline & 尝 & ஃ̊ & & کू & $\begin{array}{l}\tilde{\beta} \\
\text { gi }\end{array}$ & 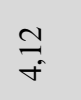 & $\tilde{m}$ & $\begin{array}{l}\text { İ } \\
\text { ô }\end{array}$ & $\begin{array}{l}n \\
i \\
i\end{array}$ & $\begin{array}{l}\varrho \\
\stackrel{-}{E}\end{array}$ & $\begin{array}{l}\text { ते } \\
\text { İ }\end{array}$ & $\begin{array}{l}\stackrel{2}{n} \\
\text { n్ర }\end{array}$ & $\underset{\mathrm{r}}{\mathrm{r}}$ & 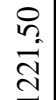 \\
\hline \multirow{6}{*}{ 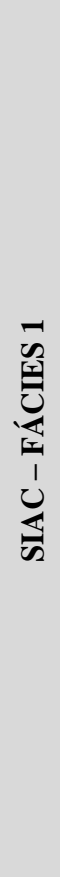 } & 을 & 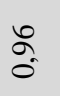 & $\begin{array}{l}\stackrel{+}{+} \\
\stackrel{+}{*}\end{array}$ & $\stackrel{\stackrel{2}{F}}{\stackrel{f}{*}}$ & $\begin{array}{l}\bar{\infty} \\
\hat{\varphi}^{0}\end{array}$ & $\stackrel{m}{=}$ & $\begin{array}{l}\text { in } \\
\text { in }\end{array}$ & $\bar{\sigma}$ & $\overline{0}$ & $\begin{array}{l}8 \\
i \\
0\end{array}$ & $\begin{array}{l}\infty \\
\stackrel{a}{0}\end{array}$ & 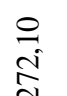 & $\begin{array}{l}\infty \\
\infty \\
i\end{array}$ & 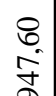 \\
\hline & 尝 & 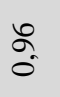 & $\begin{array}{l}\bar{\sigma} \\
\dot{\nabla}\end{array}$ & $\begin{array}{l}\stackrel{\gtrless}{f} \\
f\end{array}$ & $\begin{array}{l}n \\
\infty \\
0 \\
0 \\
-0\end{array}$ & $\frac{m}{\pi}$ & $\begin{array}{l}\text { fr } \\
\text { in }\end{array}$ & $\vec{F}$ & ֶิ & $\begin{array}{l}8 \\
\text { 8) }\end{array}$ & \begin{tabular}{c}
\multicolumn{1}{c}{} \\
$\delta_{\infty}$
\end{tabular} & $\begin{array}{l}\stackrel{0}{2} \\
\stackrel{n}{\beth}\end{array}$ & 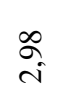 & $\begin{array}{l}8 \\
8 \\
0 \\
0 \\
0\end{array}$ \\
\hline & 窇春 & $\stackrel{\text { nू }}{\Omega}$ & $\stackrel{\infty}{\approx}$ & \begin{tabular}{l}
$\stackrel{+}{\sigma}$ \\
\multirow{\sigma}{*}{}
\end{tabular} & $\begin{array}{l}\stackrel{n}{c} \\
\hat{b}\end{array}$ & ఫू. & $\underset{i}{\stackrel{t}{*}}$ & \begin{tabular}{l}
0 \\
\multirow{0}{*}{}
\end{tabular} & $\stackrel{\Re}{\stackrel{2}{n}}$ & $\begin{array}{l}\text { ते } \\
\text { å }\end{array}$ & $\underset{\infty}{\stackrel{N}{\infty}}$ & $\begin{array}{l}\infty \\
\infty \\
\infty \\
\approx\end{array}$ & $\bar{a}$ & $\begin{array}{l}\text { 응 } \\
\stackrel{8}{8}\end{array}$ \\
\hline & 을 & 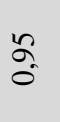 & $\frac{N}{n}$ & $\begin{array}{l}\infty \\
\infty \\
+\end{array}$ & $\stackrel{\vec{E}}{\underline{6}}$ & $\stackrel{2}{\circ}$ & $\begin{array}{l}\infty \\
\dot{\sigma} \\
i\end{array}$ & \begin{tabular}{l}
0 \\
\multirow{0}{*}{}
\end{tabular} & $\stackrel{m}{i}$ & $\begin{array}{l}\text { तิ } \\
\text { હิ }\end{array}$ & $\begin{array}{l}\infty \\
\infty \\
\infty \\
\infty\end{array}$ & 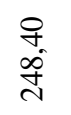 & $\tilde{m}$ & $\begin{array}{l}\infty \\
\infty \\
0 \\
0\end{array}$ \\
\hline & 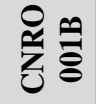 & 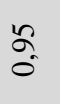 & तె & $\begin{array}{l}\tilde{\sigma} \\
\dot{n}\end{array}$ & $\begin{array}{l}8 \\
\text { fó } \\
0\end{array}$ & $\stackrel{\infty}{+\infty}_{0}^{\infty}$ & $\begin{array}{l}0 \\
0 \\
0 \\
0\end{array}$ & 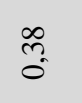 & $\begin{array}{l}\text { D } \\
\text { ñ }\end{array}$ & $\begin{array}{l}\stackrel{0}{\cong} \\
\stackrel{5}{=}\end{array}$ & $\begin{array}{l}\hat{a} \\
\hat{ \pm}\end{array}$ & $\begin{array}{l}\infty \\
\stackrel{\infty}{\infty}\end{array}$ & $\underset{\infty}{+}$ & $\frac{o}{a}$ \\
\hline & 尝 & & $\begin{array}{l}n \\
0 \\
i\end{array}$ & $\stackrel{\infty}{\stackrel{\infty}{\sim}}$ & $\begin{array}{l}R \\
\hat{b}\end{array}$ & $\stackrel{?}{\stackrel{R}{0}}$ & $\begin{array}{l}\text { So } \\
\text { in }\end{array}$ & ભે & 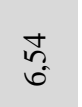 & $\begin{array}{l}\stackrel{R}{9} \\
\stackrel{+}{ \pm}\end{array}$ & $\begin{array}{l}\stackrel{0}{n} \\
\stackrel{\text { In }}{\mathbf{i}}\end{array}$ & $\begin{array}{l}\stackrel{ }{\circ} \\
\text { ని }\end{array}$ & $\vec{m}_{m}^{+}$ & 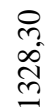 \\
\hline \multicolumn{2}{|c|}{$\underset{\mid \vec{x}}{\stackrel{\dot{x}}{x}}$} & 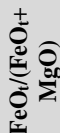 & 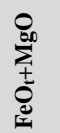 & ర్ & 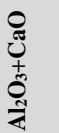 & 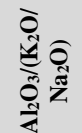 & 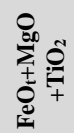 & 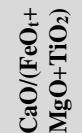 & 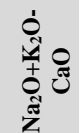 & $\underset{ \pm}{z}$ & $\begin{array}{l}\stackrel{\pi}{7} \\
+ \\
\frac{1}{2}\end{array}$ & تِّ & 㐫 & 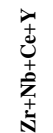 \\
\hline
\end{tabular}




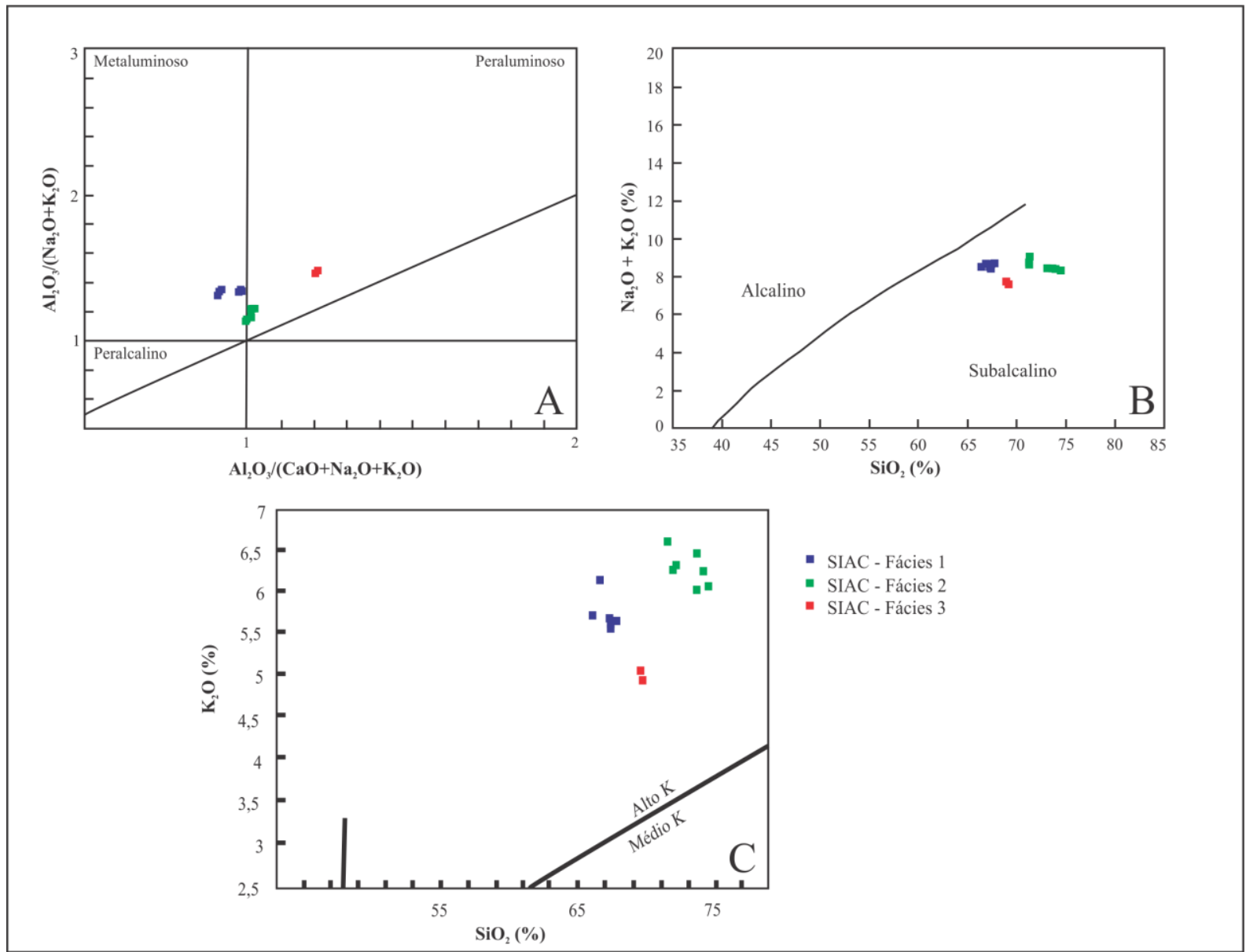

Figura 2.10. Características geoquímicas dos granitos da SIAC: A) o índice de saturação em alumina (ISA ou A/CNK) de Shand, segundo Maniar e Piccoli (1989); B) o índice de alcalinidade segundo Irvine e Baragar (1971); C) diagrama do teor de potássio com base na correlação entre $\mathrm{K}_{2} \mathrm{O} \times \mathrm{SiO}_{2}$, modificado de Le Maitre (1989, in Rollinson 1993).

Foram analisadas 7 amostras do hornblenda-biotita granito inequigranular médio (Fácies 2), as quais revelaram concentrações de $\mathrm{SiO}_{2}=71,31$ a $74,86 \%, \mathrm{Al}_{2} \mathrm{O}_{3}=11,84$ a 13,45\%, $\mathrm{Fe}_{2} \mathrm{O}_{3}$ (total) $=2,28$ a $3,43 \%, \mathrm{CaO}=0,82$ a $1,16 \%, \mathrm{Na}_{2} \mathrm{O}=2,15$ a $2,47 \%, \mathrm{~K}_{2} \mathrm{O}=6,07$ a $6,55 \%, \mathrm{TiO}_{2} \sim 0,30 \%$ e teores de $\mathrm{MnO}, \mathrm{MgO}$ e $\mathrm{P}_{2} \mathrm{O}_{5}$ da ordem de elementos traços (Tabela 2.1), índice de saturação em alumina (ISA) metaluminoso a peraluminoso e assinatura subalcalina $\left(\mathrm{K}_{2} \mathrm{O}+\mathrm{Na}_{2} \mathrm{O}=8,22\right.$ a $\left.9,02 \%\right)$ de alto potássio (Figuras 2.10A, 2.10B , 2.10C). Em relação aos elementos traços (Tabela 2.1), apresenta teores entre 500 e 100 ppm para o Ba, Rb, Th, Zn, Y e Zr, teores entre 100-50 ppm para o Rb, Sr, Y e Zn, e teores menores que 50 ppm para o $\mathrm{Be}, \mathrm{Co}, \mathrm{Cs}, \mathrm{Ga}, \mathrm{Hf}, \mathrm{Nb}, \mathrm{Sc}, \mathrm{Sn}, \mathrm{Ta}, \mathrm{U}, \mathrm{W}, \mathrm{Cd}, \mathrm{Au}, \mathrm{As}, \mathrm{Cu}, \mathrm{Mo}$, Ni e Pb. O padrão de distribuição dos elementos terras raras (ETR; Figura 2.11C), apresenta fraca anomalia negativa em $\mathrm{Eu}$, com $\mathrm{Eu} / \mathrm{Eu}_{\mathrm{N}}=0,14$ a 0,17, moderado enriquecimento dos REE leves, de razão $[\mathrm{La} / \mathrm{Sm}]_{\mathrm{N}}=3,74$ a 5,10 , em relação aos pesados, de razão $[\mathrm{Gd} / \mathrm{Yb}]_{N}=1,79$ a 2,13, o que indica um padrão de fracionamento moderado a alto, de razão $[\mathrm{La} / \mathrm{Yb}]_{\mathrm{N}}=10,72$ a 18,06. O padrão de distribuição dos elementos compatíveis e incompatíveis (Figura 2.11D), normalizados ao Manto Primordial de Wood et al. (1979), revela anomalias positivas em Rb, Th, La, Nd, Hf, Zr, Sm e Tb e anomalias negativas em $\mathrm{Ba}, \mathrm{Ta}, \mathrm{Nb}, \mathrm{Sr}, \mathrm{P}$ e Ti.

Foram analisadas 2 amostras do biotita granito inequigranular fino (Fácies 3), as quais revelaram concentrações de $\mathrm{SiO}_{2}=69,23$ a 69,54 \%, $\mathrm{Al}_{2} \mathrm{O}_{3} \sim 14,97 \%, \mathrm{Fe}_{2} \mathrm{O}_{3}$ (total) $=3,86$ a 3,98 \%, $\mathrm{CaO}$ $\sim 1,18 \%, \mathrm{Na}_{2} \mathrm{O} \sim 3,28 \%, \mathrm{~K}_{2} \mathrm{O}=4,46$ a $4,58 \%, \mathrm{TiO}_{2} \sim 0,45 \%, \mathrm{MgO} \sim 0,52 \%$ e teores de $\mathrm{MnO}$ e $\mathrm{P}_{2} \mathrm{O}_{5}$ da ordem de elementos traços (Tabela 2.1), índice de saturação em alumina (ISA) peraluminoso e 
assinatura subalcalina $\left(\mathrm{K}_{2} \mathrm{O}+\mathrm{Na}_{2} \mathrm{O}=7,74\right.$ a $\left.7,81 \%\right)$ de alto potássio (Figuras 2.10A, 2.10B, 2.10C). Em relação aos elementos traços, apresenta teores superiores a $500 \mathrm{ppm}$ para o $\mathrm{Ba}$, teores entre $500 \mathrm{e}$ 100 ppm para o Rb, Sr, Zr e Zn, teores entre 100-50 ppm para o Th e Y, e teores menores que 50 ppm para o $\mathrm{Be}, \mathrm{Co}, \mathrm{Cs}, \mathrm{Ga}, \mathrm{Hf}, \mathrm{Nb}, \mathrm{Sc}, \mathrm{Sn}, \mathrm{Ta}, \mathrm{U}, \mathrm{W}, \mathrm{Cd}, \mathrm{Au}, \mathrm{As}, \mathrm{Cu}, \mathrm{Mo}$, Ni e $\mathrm{Pb}$. O padrão de distribuição dos elementos terras raras (ETR; Figura 2.11E), também apresenta fraca anomalia negativa em $\mathrm{Eu}$, com $\mathrm{Eu} / \mathrm{Eu}_{\mathrm{N}}=0,24$ moderado enriquecimento dos $\mathrm{REE}$ leves, de razão $[\mathrm{La} / \mathrm{Sm}]_{\mathrm{N}}=$ 4,85 , em relação aos pesados, de razão $[\mathrm{Gd} / \mathrm{Yb}]_{\mathrm{N}}=2,04$ a 2,08 , o que indica um padrão de fracionamento alto, de razão $[\mathrm{La} / \mathrm{Yb}]_{\mathrm{N}}=18,08$ a 18,14. O padrão de distribuição dos elementos compatíveis e incompatíveis (Figura 2.11F), normalizados ao normalizados ao Manto Primordial de Wood et al. (1979), revela anomalias positivas em $\mathrm{Rb}$, Th, Ta, Nb, La, Ce, Nd, Hf, Sm e Tb e anomalias negativas em $\mathrm{Ba}, \mathrm{P}, \mathrm{Sr}$ e Ti.

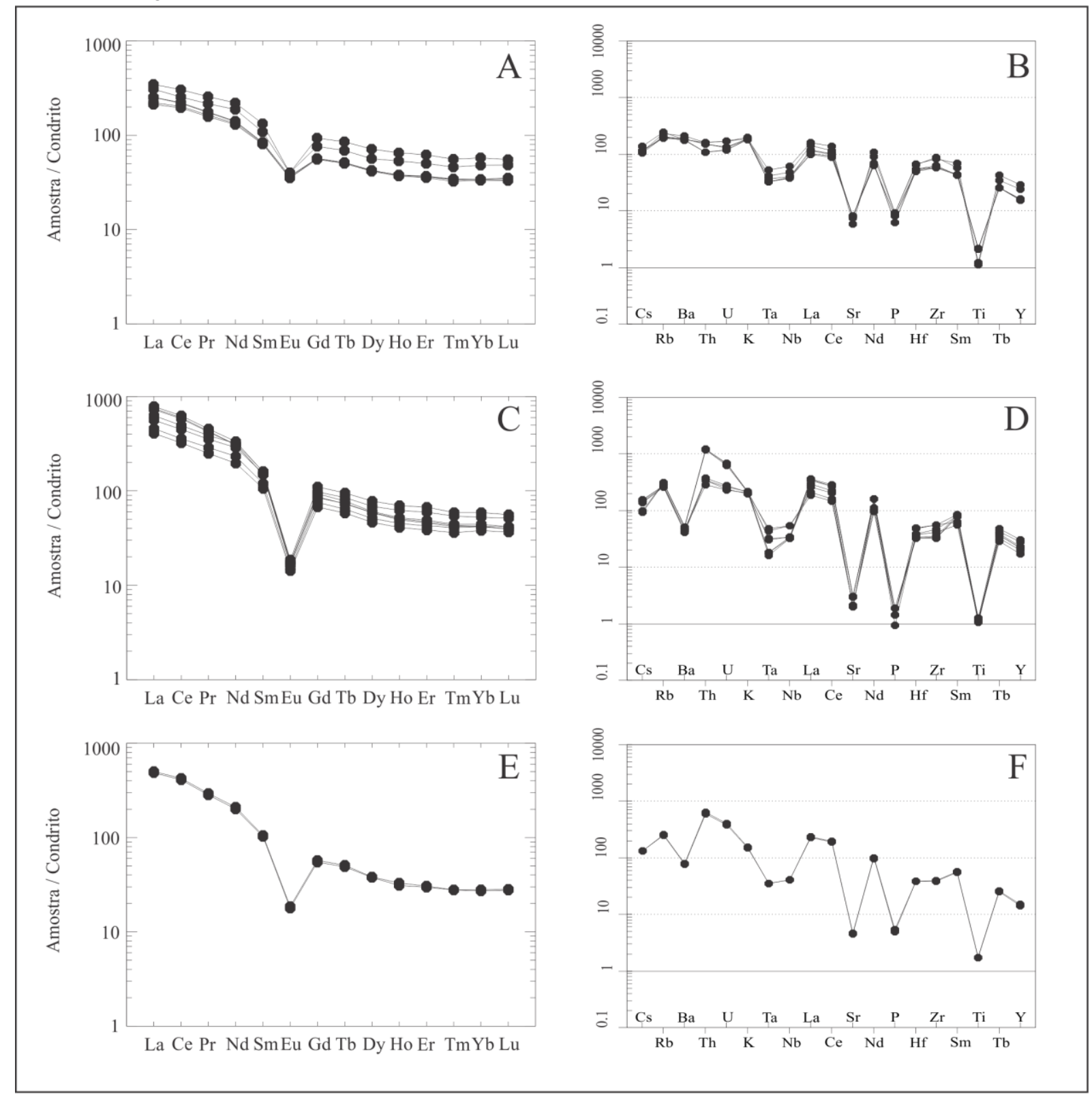

Figura 2.11. Comparação entre os padrões de distribuição dos ETR e multielementos dos granitos da SIAC, com valores normalizados, respectivamente, segundo os condritos de Boynton (1984) e o Manto Primordial de Wood et al. (1979): A e B) SIAC Fácies 1; C e D) SIAC Fácies 2; E e F) SIAC Fácies 3. 


\subsection{DISCUSSÕES}

As rochas da SIAC, de uma maneira geral, apresentam pequenas diferenças geoquímicas em termos de conteúdos de alguns elementos maiores, traços e terras raras, porém, com padrões de distribuição bastante semelhantes, denunciando, pelo ponto de vista geoquímico, um processo de cristalização fracionada para essas rochas.

A análise modal obtida para as três fácies da SIAC (Figura 2.3) mostra que as mesmas são monzogranitos. Para colaborar com essa análise, estudos geoquímicos foram realizados, objetivando uma classificação química dessas rochas plutônicas, onde foram utilizados os diagramas $R_{1} \times R_{2}$ de De La Roche et al. (1980), o diagrama TAS (total de álcalis versus $\mathrm{SiO}_{2}$ ) de Cox et al. (1979, modificado de Le Maitre et al. 1989) e diagrama TAS de Middlemost (1994). Em ambos diagramas, as fácies da SIAC caíram no campo dos granitos (Figura 2.12).

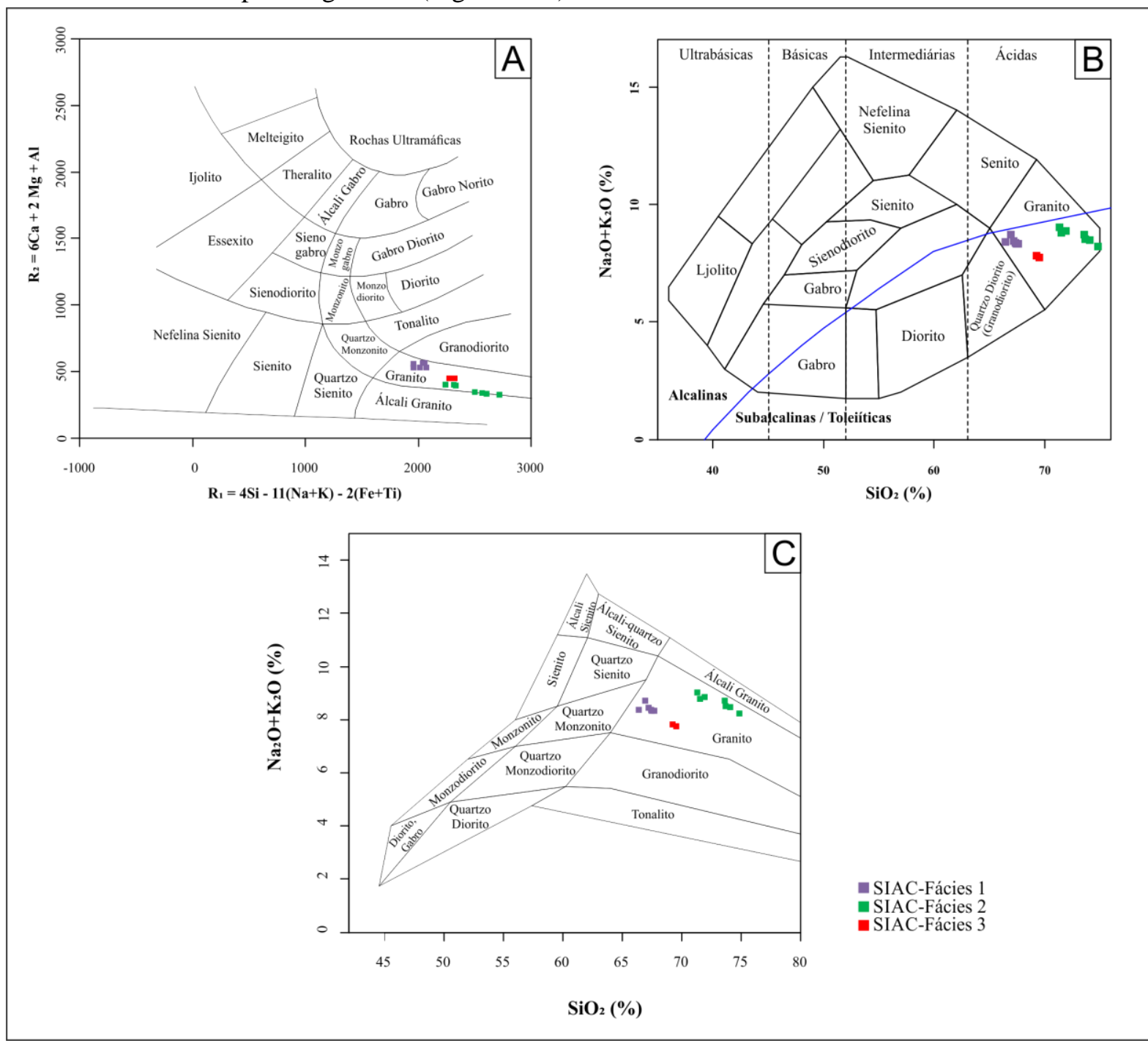

Figura 2.12. Diagramas de Classificação Química de Rochas Plutônicas aplicados às rochas da SIAC. Em A, Diagrama multicatiônico $\mathrm{R}_{1} \times \mathrm{R}_{2}$ de De La Roche et al. (1980); em B, diagrama TAS de Cox et al. (1979, modificado de Le Maitre et al. 1989); e, em C, diagrama TAS de Middlemost, (1994).

As rochas da SIAC, quando plotadas em diagramas de correlação do tipo Harker, tendem a se distribuir segundo um trend de mesma linhagem geoquímica (Figura 2.13). A exceção são as amostras do biotita granito inequigranular fino (Fácies 3), as quais se mostram distribuídas em uma posição intermediária nos diagramas Harker, nem sempre acompanhando o trend de evolução geoquímica (Figura 2.13). 
Metalogênese do Depósito de Estanho Liberdade, Campo Novo de Rondônia - RO

Paulo Sérgio Mendes dos Santos Júnior
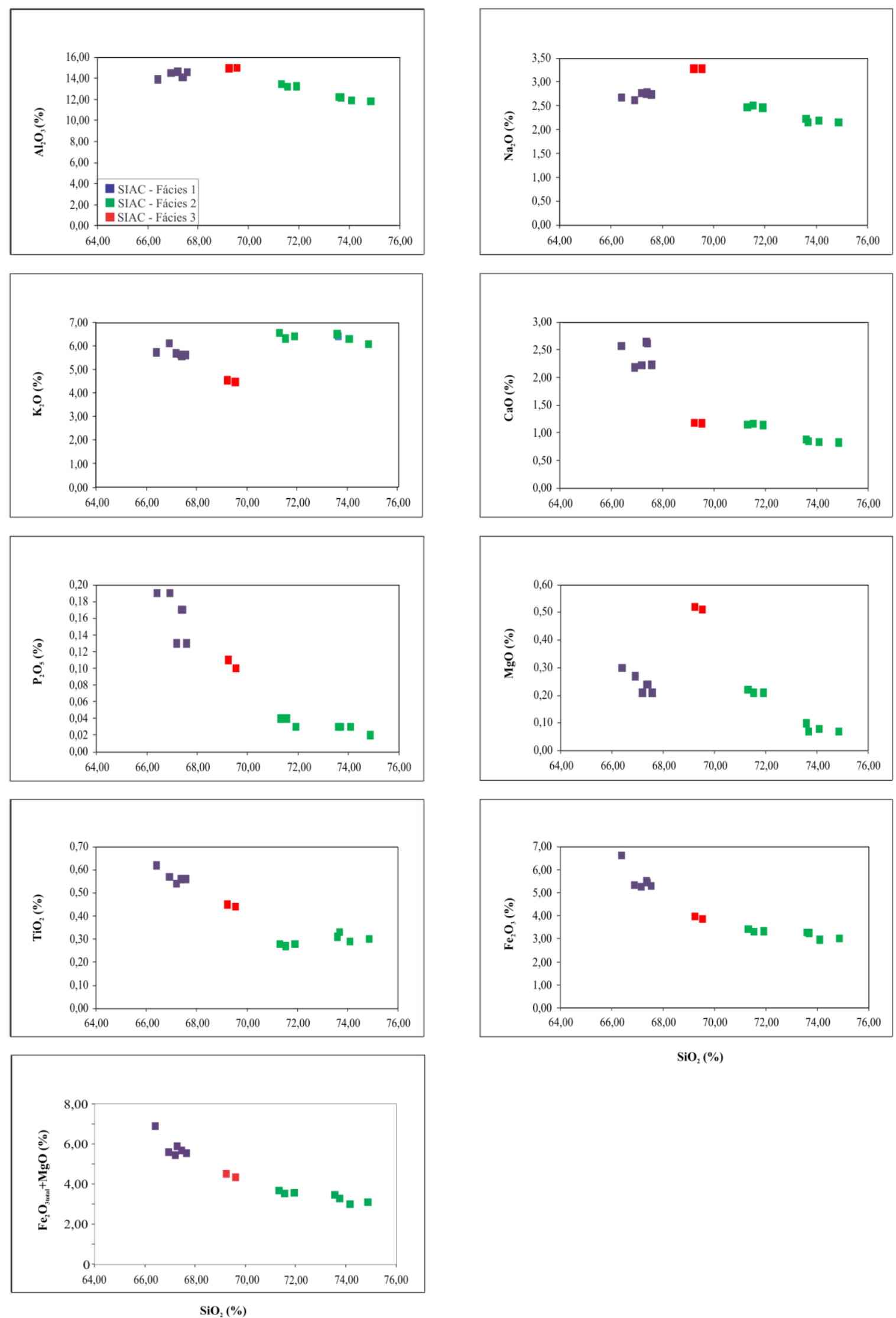

Figura 2.13. Diagrama de correlação do tipo Harker para elementos maiores vs. $\mathrm{SiO}_{2}$, aplicado às rochas da SIAC. 
Essas rochas (Fácies 3), também, se mostram essencialmente peraluminosas, ao contrário das demais fácies que são meta a peraluminosas (Figura 2.10A). Esse comportamento do biotita granito inequigranular fino pode ser interpretado como produto de pulsos magmáticos distintos, porém, de composição química similar ao dos outros dois fácies. Por outro lado, a interação com fluidos hidrotermais de derivação magmática pode ter modificado, pelo menos parcialmente, a assinatura geoquímica dessa fácies, sobretudo em relação aos conteúdos de $\mathrm{Na}_{2} \mathrm{O}, \mathrm{K}_{2} \mathrm{O}, \mathrm{CaO}$ e $\mathrm{MgO}$.

Em geral, observa-se um progressivo decréscimo de $\mathrm{Al}_{2} \mathrm{O}_{3}, \mathrm{Na}_{2} \mathrm{O}, \mathrm{CaO}, \mathrm{P}_{2} \mathrm{O}_{5}, \mathrm{MgO}, \mathrm{Ba}, \mathrm{Sr}$ e $\mathrm{Hf}$, em relação ao aumento do conteúdo de $\mathrm{SiO}_{2}$, sugerindo um efetivo processo de fracionamento do plagioclásio e da apatita durante a evolução magmática. Tal comportamento é também observado para o $\mathrm{Fe}_{2} \mathrm{O}_{3}$ e $\mathrm{TiO}_{2}$, o qual pode ser devido ao fracionamento de hornblenda e biotita. Por outro lado, notase uma correlação positiva entre $\mathrm{SiO}_{2}$ vs $\mathrm{K}_{2} \mathrm{O}$ e Rb, produto do aumento na participação de feldspato alcalino e biotita nos tipos petrográficos mais evoluídos.

Em relação a alguns dos elementos traços $(\mathrm{Ba}, \mathrm{Rb}, \mathrm{Sr}, \mathrm{Zr}$, $\mathrm{Hf}$ e $\mathrm{Ga})$, também se nota, que as amostras da Fácies 3 ocupam posição intermediária nos diagramas Harker (Figura 2.14).
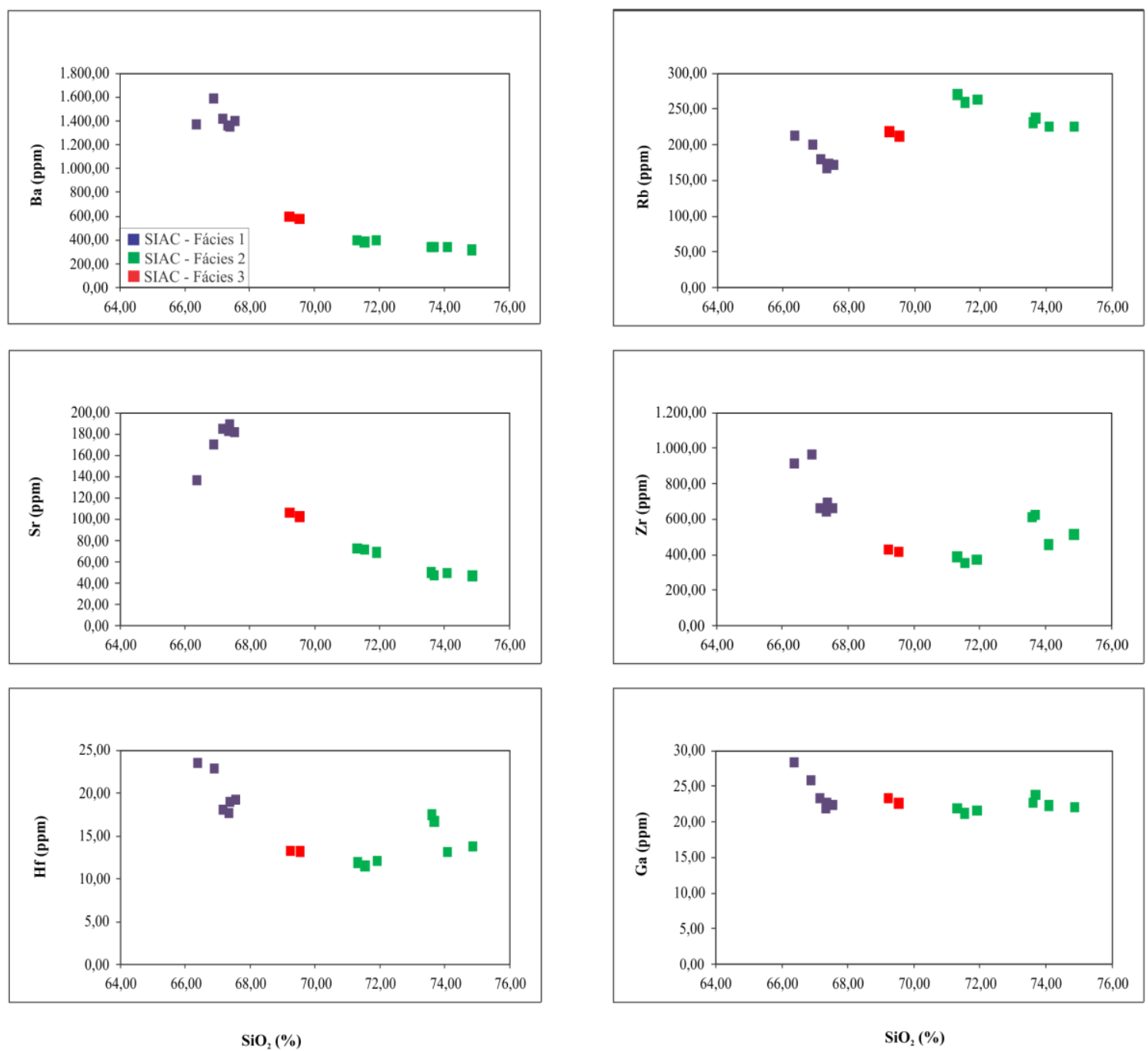

Figura 2.14. Diagrama de correlação do tipo Harker para elementos traços vs. $\mathrm{SiO}_{2}$, aplicado às rochas da SIAC.

A correlação negativa com os elementos $\mathrm{Ba}, \mathrm{Sr}$ e $\mathrm{Hf}$ indica um efetivo processo de fracionamento do plagioclásio, enquanto que em relação ao $\mathrm{Zr}$ nota-se menor participação das fases minerais residuais (tipo zircão) nos estágios magmáticos mais evoluídos, indicando seu comportamento compatível com consequente remoção através da precipitação de zircão durante a 
cristalização das fácies mais precoces. Já o conteúdo de Ga se mantém aproximadamente constante ao longo da evolução magmática.

Os elementos de afinidade geoquímica e metalogenética com o $\mathrm{Sn}$, tais como $\mathrm{Nb}$ e $\mathrm{Ta}$, se mostram distribuídos de modo homogêneo nos diferentes tipos petrográficos. Por outro lado, Th e U exibem correlação positiva e variam proporcionalmente ao conteúdo de Sn na Fácies 3 associado a mineralização (Tabela 2.1).

As rochas da SIAC apresentam assinatura subalcalina de Alto Potássio (Figuras 2.10B e 2.10C) e, quando plotadas nos diagramas $\mathrm{Na}_{2} \mathrm{O}+\mathrm{K}_{2} \mathrm{O}-\mathrm{CaO}$ e $\mathrm{FeO}_{t} /\left(\mathrm{FeO}_{t}+\mathrm{MgO}\right)$ x $\mathrm{SiO}_{2}$, de Frost $e t$ al. (2001), as fácies da SIAC caem no campo dos tipos alcalinos-cálcicos ferrosos (Figura 2.15). Segundo Frost et al. (2001), granitos tipo A ferrosos refletem uma estreita afinidade a magmas alcalinos reduzidos e anidros, comuns em ambientes extensionais, geralmente, mais quentes e mais propensos a sofrer extenso processo de fracionamento.
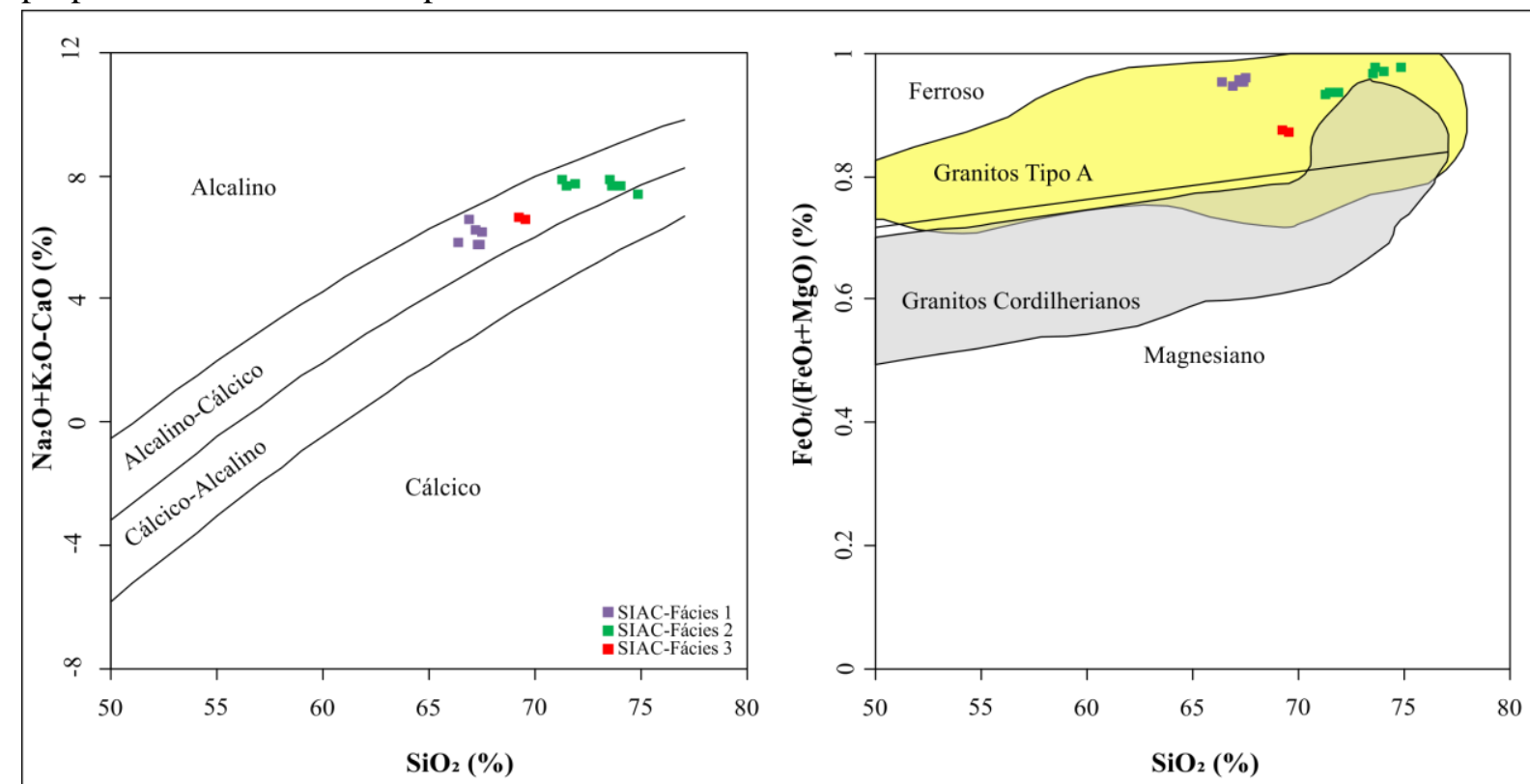

Figura 2.15. Diagramas $\mathrm{Na}_{2} \mathrm{O}+\mathrm{K}_{2} \mathrm{O}-\mathrm{CaO}$ e $\mathrm{FeO}_{t} /(\mathrm{FeO}+\mathrm{MgO})$ vs. $\mathrm{SiO}_{2}$, aplicados às rochas da $\mathrm{SIAC}$, modificado de Frost et al. (2001).

As rochas da SIAC apresentam caráter metaluminoso a peraluminoso, com elevados teores de $\mathrm{SiO}_{2}, \mathrm{Nb}, \mathrm{Y}, \mathrm{Zr}$ e Ce, elevadas razões $\mathrm{K}_{2} \mathrm{O} / \mathrm{Na}_{2} \mathrm{O}, 10^{4} \mathrm{Ga} / \mathrm{Al}$ e baixos teores de $\mathrm{TiO}_{2}, \mathrm{MgO}, \mathrm{CaO}, \mathrm{P}_{2} \mathrm{O}_{5}$, $\mathrm{MnO}$ e Eu. Estas características geoquímicas são comparáveis àquelas apresentadas pelos granitos do tipo A (Collins et al. 1982, Whalen et al. 1987, Eby 1992). Porém, Whalen et al. (1987) mostram que algumas suítes graníticas dos tipos I e $\mathrm{S}$ fortemente fracionadas apresentam características geoquímicas semelhantes àquelas dos granitos do tipo $\mathrm{A}$, principalmente em relação ao comportamento em correlação positiva ou negativa no diagrama $\mathrm{P}_{2} \mathrm{O}_{5} v s . \mathrm{SiO}_{2}$ e na razão Ga/Al, que, também, é alta nos granitos tipo I muito fracionados. Taylor (1992) considera os subtipos denominados de "baixo P" $\left(\mathrm{P}_{2} \mathrm{O}_{5}<0,10 \%, \mathrm{SiO}_{2}>73 \%, \mathrm{Al}_{2} \mathrm{O}_{3}=12\right.$ a $14,5 \%$ e A/CNK = 1,0 a 1,2) e "alto $\mathrm{P}^{\prime}\left(\mathrm{P}_{2} \mathrm{O}_{5}>0,40 \%, \mathrm{SiO}_{2}=68\right.$ a $73 \%, \mathrm{Al}_{2} \mathrm{O}_{3} 14,5$ a $20 \%$ e $\mathrm{A} / \mathrm{CNK}=1,2$ a 1,5$)$ como sendo os respectivos exemplos de granitos do tipo I e $\mathrm{S}$ fortemente fracionados.

Whalen et al. (1987) consideram a utilização dos diagramas de correlação entre $10^{4} \mathrm{Ga} / \mathrm{Al} x$ $\mathrm{K}_{2} \mathrm{O}+\mathrm{Na}_{2} \mathrm{O}, \mathrm{K}_{2} \mathrm{O}+\mathrm{Na}_{2} \mathrm{O} / \mathrm{CaO}$ e vários outros elementos traços, entre os quais $\mathrm{Nb}, \mathrm{Zr}$, Ce e $\mathrm{Y}$ como bons parâmetros geoquímicos para discriminar os granitos do tipo A (Figura 2.16). 

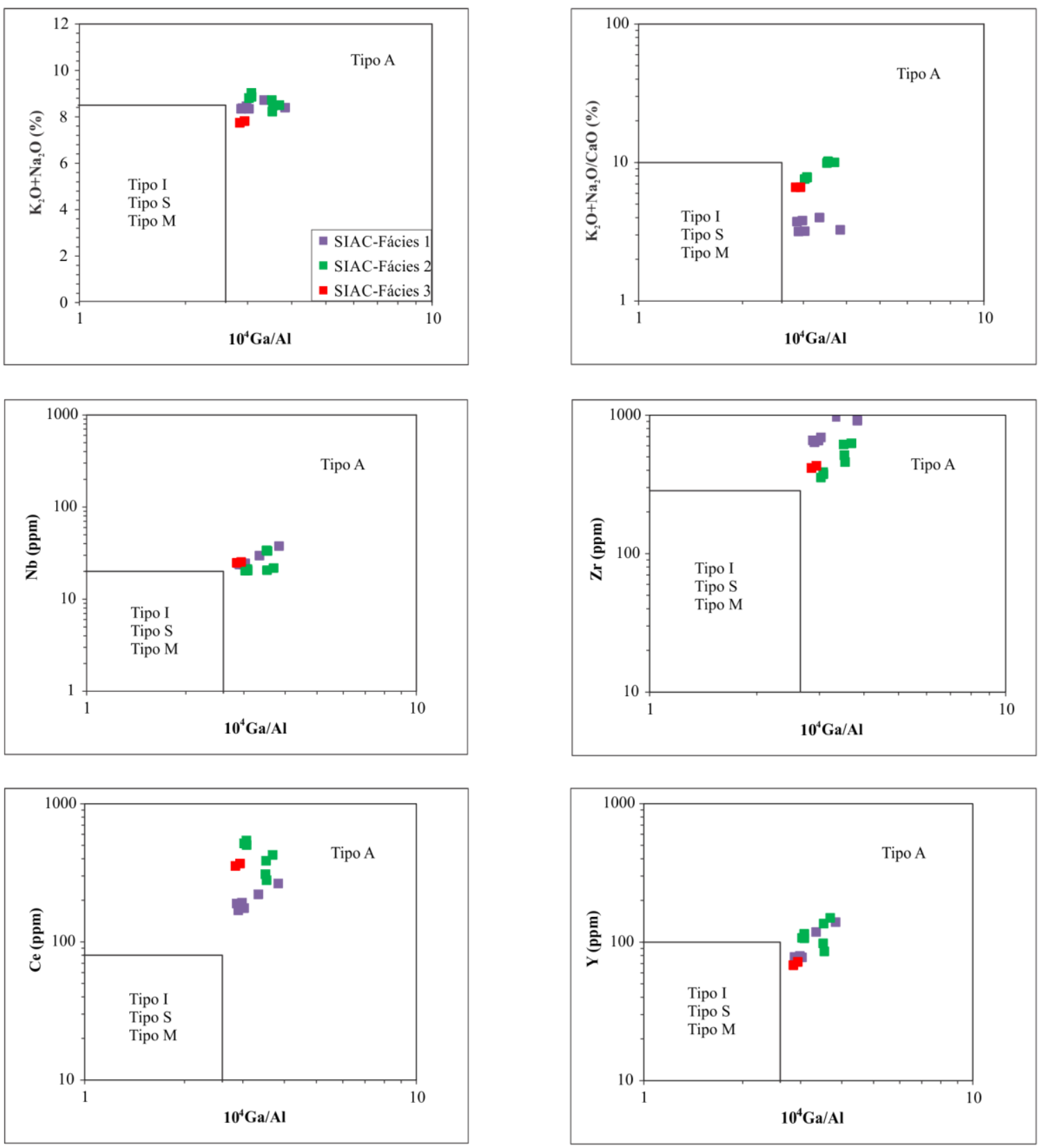

Figura 2.16. Diagramas discriminantes aplicados para tipologia de granitos e elaborados a partir das correlações entre a razão $10^{4} \mathrm{Ga} / \mathrm{Al}$ x $\mathrm{K}_{2} \mathrm{O}+\mathrm{Na}_{2} \mathrm{O}, \mathrm{K}_{2} \mathrm{O}+\mathrm{Na}_{2} \mathrm{O} / \mathrm{CaO}, \mathrm{Nb}, \mathrm{Zr}$, Ce e Y. Observar as amostras das fácies da SIAC distribuídas no campo dos granitos do tipo A (Whalen et al. 1987).

Segundo Eby (1992), outro bom parâmetro geoquímico para a distinção dos granitos do tipo A, é a correlação entre as razões $10^{4} \mathrm{Ga} / \mathrm{Al} \times \mathrm{Eu} / \mathrm{Eu}^{*}$, onde $\mathrm{Eu} / \mathrm{Eu}^{*}=\mathrm{Eu}_{\mathrm{N}} / \sqrt{ }\left(\mathrm{Sm}_{\mathrm{N}}\right) \mathrm{x}\left(\mathrm{Gd}_{\mathrm{N}}\right)$, além da razão entre $\mathrm{Zr}+\mathrm{Nb}+\mathrm{Ce}+\mathrm{Y} \times 10^{4} \mathrm{Ga} / \mathrm{Al}$. Nestes diagramas, as amostras de granitos das fácies da SIAC também se distribuem no campo dos granitos do tipo A (Figura 2.17). Nos diagramas Nb-Y-Ce, Nb-Y$3 \mathrm{Ga}, \mathrm{Rb} / \mathrm{Nb}-\mathrm{Y} / \mathrm{Nb}$ e $\mathrm{Sc} / \mathrm{Nb}-\mathrm{Y} / \mathrm{Nb}$ de Eby (1992), as amostras das fácies da SIAC caem no campo dos granitos do tipo A subtipo $\mathrm{A}_{2}$ (Figura 2.17), com relação $\mathrm{Y} / \mathrm{Nb}>2,5$, representando granitos colocados durante o colapso extensional de um cinturão orogênico, produto de refusão parcial de parte da litosfera, especialmente a crosta intermediária, além da interação entre a crosta e o manto litosférico. Segundo Eby (1992), os granitos rapakivi são considerados verdadeiros exemplos do magmatismo anorogênico pós colisional. 

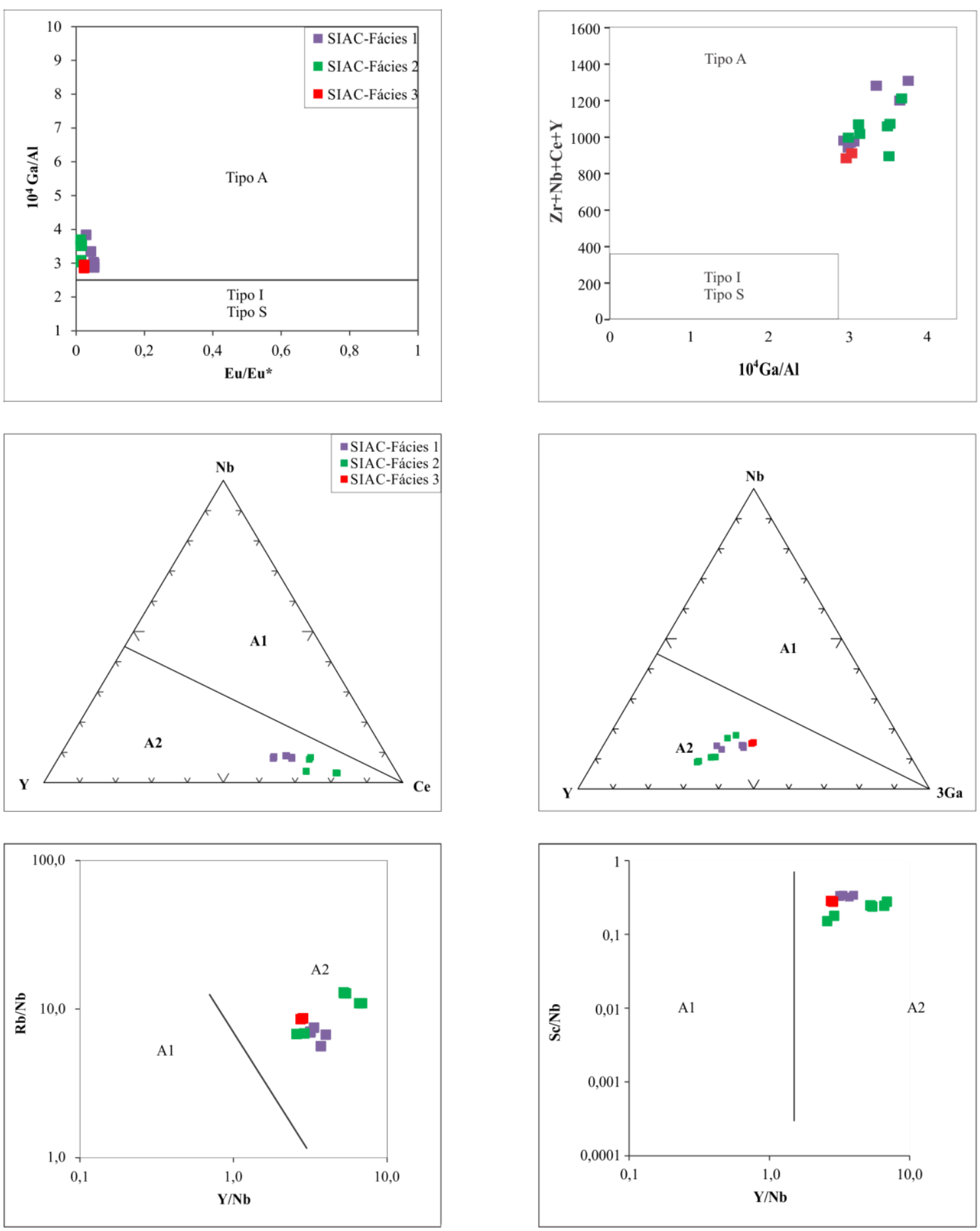

Figura 2.17. Diagramas discriminantes aplicados para tipologia de granitos, elaborados a partir da correlação entre a razão $10^{4} \mathrm{Ga} / \mathrm{Al} \times \mathrm{Eu} / \mathrm{Eu} *$ e $\mathrm{Zr}+\mathrm{Nb}+\mathrm{Ce}+\mathrm{Y} \times 10^{4} \mathrm{Ga} / \mathrm{Al}$, além dos diagramas discriminantes para divisão dos granitos tipo $\mathrm{A}$ nos subtipos $\mathrm{A}_{1}$ e $\mathrm{A}_{2}$, aplicados às rochas das fácies da SIAC. Observar as amostras das fácies da SIAC distribuídas no campo dos granitos do tipo A subtipo $\mathrm{A}_{2}$ (Eby 1992).

Dall'Agnol e Oliveira (2007) consideram como bons parâmetros para a caracterização de granitos tipo A e granitos cálcio-alcalinos a razão $\mathrm{CaO} /\left(\mathrm{FeO}_{t}+\mathrm{MgO}+\mathrm{TiO}_{2}\right) \times \mathrm{CaO}+\mathrm{Al}_{2} \mathrm{O}_{3}$ e para a discriminação entre granitos tipo A reduzidos e oxidados, além de granitos cálcio-alcalinos, a razão $\mathrm{FeO}_{t} /\left(\mathrm{FeO}_{\mathrm{t}}+\mathrm{MgO}\right) \times \mathrm{Al}_{2} \mathrm{O}_{3} /\left(\mathrm{K}_{2} \mathrm{O}+\mathrm{Na}_{2} \mathrm{O}\right)$, conforme visualizado na Figura 2.18. 


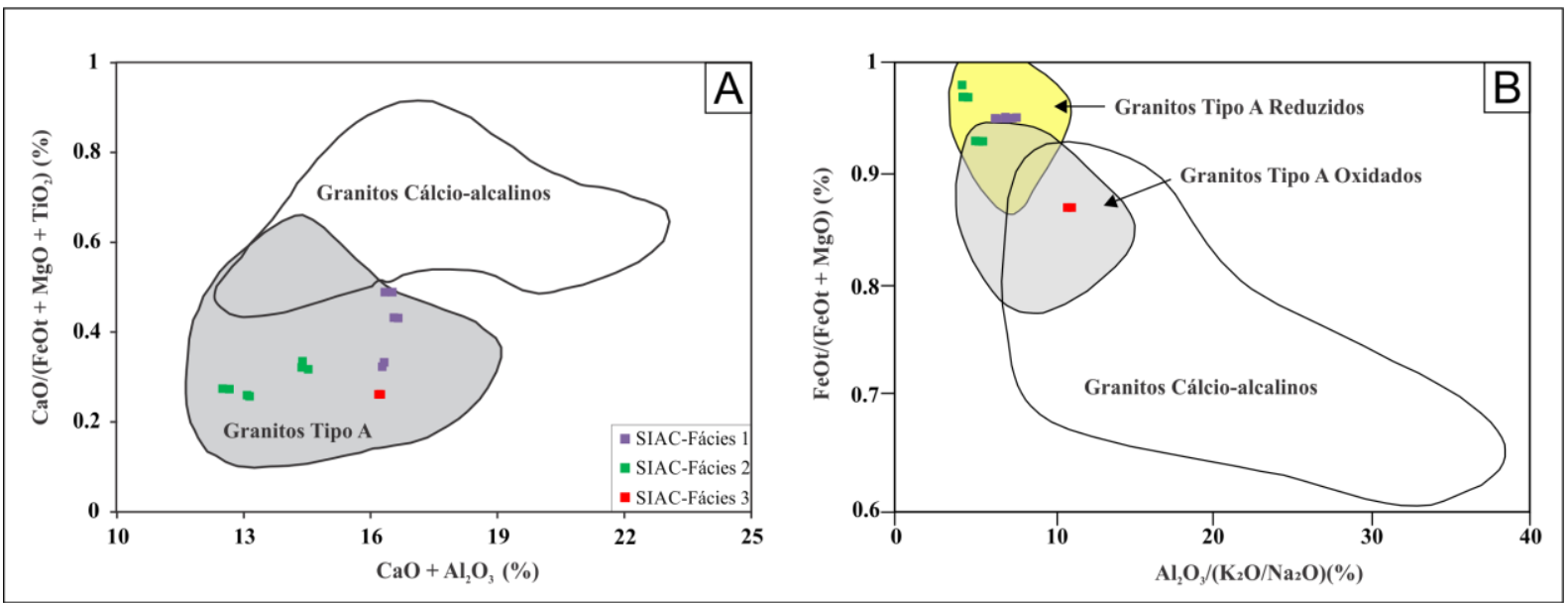

Figura 2.18. Diagramas discriminantes de granitos tipo A e cálcio-alcalinos e granitos tipo A reduzidos e oxidados e cálcio-alcalinos, aplicados às rochas das fácies da SIAC, segundo Dall'Agnol e Oliveira (2007).

No primeiro gráfico (Figura 2.18A), as amostras das Fácies da SIAC caem no campo dos granitos tipo A, porém, no segundo gráfico (Figura 2.18B), as amostras das Fácies 1 e 2 caem no campo dos granitos tipo A reduzidos, enquanto que as amostras da Fácies 3 caem no campo dos granitos oxidados e/ou cálcio-alcalinos. Segundo Dall'Agnol e Oliveira (2007), o digrama de granitos oxidados e reduzidos são utilizados para a determinação de granitos das séries magnetita e ilmenita. $\mathrm{O}$ diagrama de granitos oxidados e reduzidos mostra que as Fácies 1 e 2 da SIAC apresentam-se no campo dos granitos reduzidos, o que, em conjunto com dados petrográficos, nos permite dizer que essa suíte granítica faz parte da série ilmenita. Já a Fácies 3 cai no campo dos granitos oxidados. Provavelmente, essa Fácies é o produto de pulsos magmáticos distintos, porém, de composição química similar ao das outras duas fácies, conforme já indicado ou trata-se da interação com fluidos hidrotermais de derivação magmática que pode ter modificado a química da rocha e, assim, fornecer uma leitura errada. Além disso, as altas razões $\mathrm{FeO}_{\mathrm{t}} /\left(\mathrm{FeO}_{\mathrm{t}}+\mathrm{MgO}\right)$, combinadas aos baixos valores de $\mathrm{Al}_{2} \mathrm{O}_{3}$, demonstram que a SIAC não possui afinidade com as séries cálcico-alcalinas (Figura 2.18B). A exceção é a Fácies 3, que caiu na interface entre os granitos tipo A oxidados e granitos cálcioalcalinos.

Dall’Agnol e Oliveira (2007) sugerem que os granitos rapakivis clássicos são reduzidos e classificados como sendo da série ilmenita. Estes autores, ainda sugerem que os granitos tipo A reduzidos são derivados de magmas ígneos quartzo-feldspáticos, possivelmente, com uma contribuição de rochas metassedimentares (Dall'Agnol et al. 2005) ou, a partir de fontes toleiíticas diferenciadas (Frost et al. 1999).

Nos diagramas discriminantes para ambientes tectônicos, elaborados através da correlação entre elementos de baixa mobilidade ( $\mathrm{Rb} \times \mathrm{Y}+\mathrm{Nb}, \mathrm{Nb} \times \mathrm{Y}, \mathrm{Ta} \times \mathrm{Yb}$ e $\mathrm{Rb} \times \mathrm{Y}+\mathrm{Ta}$ ) e proposto por Pearce et al. (1984), observa-se que as rochas da SIAC se distribuem, preferencialmente no campo dos granitos intraplaca (Figura 2.19).

Devido a sua importância metalogenética e significado tectônico, a evolução petrogenética dos granitos do tipo A ainda é motivo de discussão, sobretudo quando se procura esclarecer qual ou quais mecanismos atuantes nesta petrogênese, ou seja, se ocorreu fusão parcial, cristalização fracionada ou metassomatismo.

Collins et al. (1982), Whalen et al. (1987), Landenberger e Collins (1996), entre outros, consideram que os granitos do tipo A evoluíram a partir da fusão parcial de rochas félsicas anidras (granulitos), produzindo um fundido de alta temperatura, baixa viscosidade, sem restito, pobre em $\mathrm{H}_{2} \mathrm{O}$ e contendo F e Cl. Por outro lado, Eby (1990), Creaser et al. (1991), Eby (1992), King et al. (2001), 
entre outros, consideram que os granitos do tipo A também evoluem a partir da fusão parcial de rochas ígneas (granitos do tipo I) de composição tonalítica a granodiorítica, produzindo um fundido com as mesmas características físico-químicas dos fundidos de rochas granulíticas.
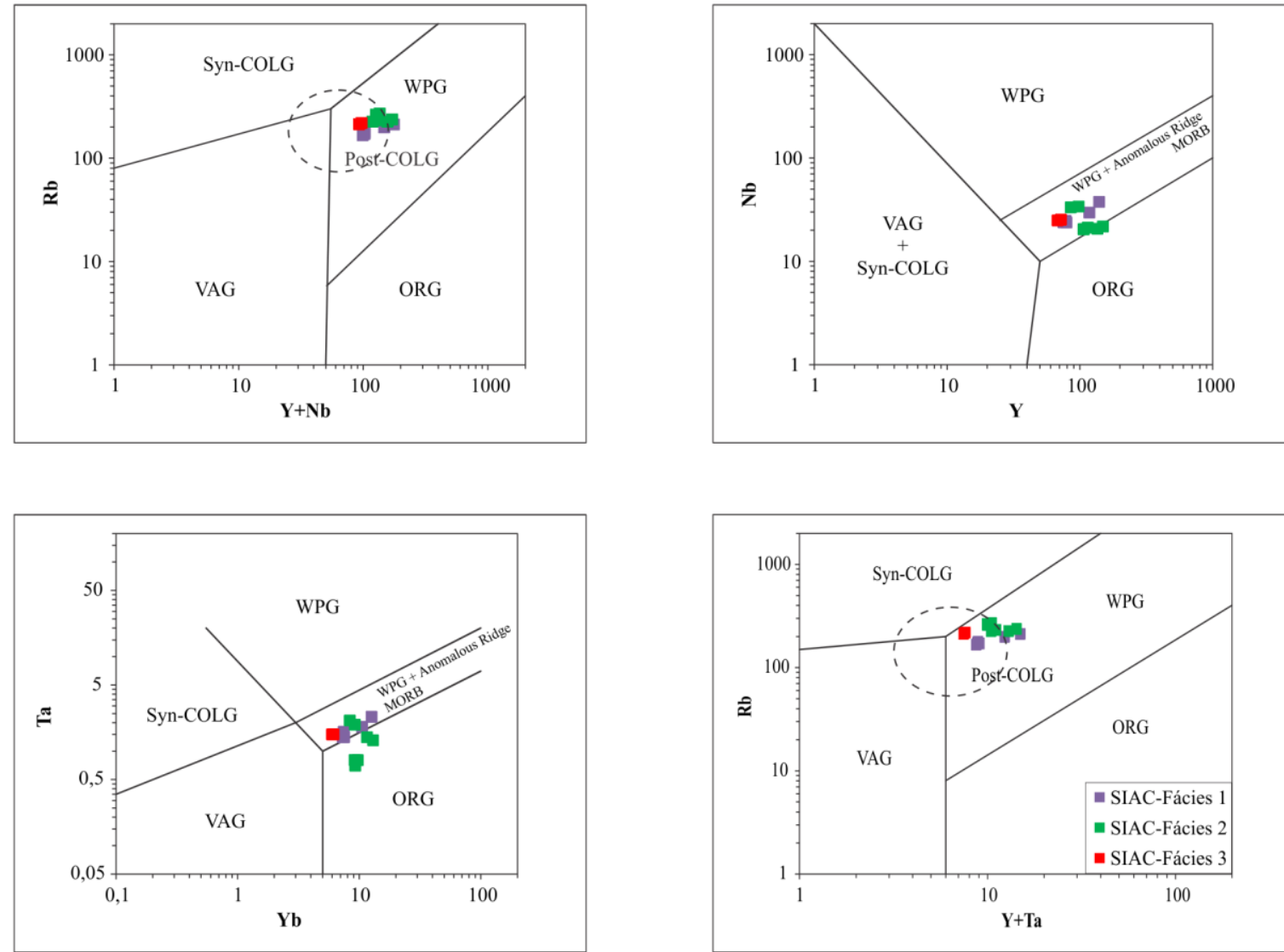

Figura 2.19. Diagramas discriminantes de ambientes tectônicos aplicados às rochas das fácies da SIAC, segundo Pearce et al. (1984). Siglas: WPG = granitos intraplaca, ORG = granitos de cadeias oceânicas, $\mathrm{VAG}=$ granitos de arco vulcânico, Syn-COLG = granitos sincolisionais e Post-COLG = granitos pós-colisionais.

Entretanto, há certo consenso de que os elevados conteúdos de Nb, F, B, Ga, ETR, Y, Zr e voláteis $\left(\mathrm{H}_{2} \mathrm{O}\right)$, associados aos baixos conteúdos de $\mathrm{Al}, \mathrm{Mg}, \mathrm{Ca}$ e Eu nestas rochas, são indicativos da ação subsequente do processo de cristalização fracionada, o qual teria sido responsável pela separação de fases fluidas e geração de depósitos minerais. 


\section{CAPÍTULO 3}

\section{SISTEMA MINERALIZADO \& COMPOSIÇÃO QUÍMICA DA CASSITERITA NO DEPÓSITO DE ESTANHO LIBERDADE}

\subsection{APRESENTAÇÃO}

No depósito de estanho Liberdade os locais onde a cassiterita cristalizou são representados por veios e vênulas de quartzo e greisens, além de uma discreta faixa de sedimentos colúvio-aluvionares explorada de forma rudimentar por garimpeiros. Os veios estão distribuídos em praticamente toda área do depósito, bem como em outras áreas da Suíte Intrusiva Alto Candeias e podem hospedar agregados maciços de cristais de cassiterita associados a quartzo e arsenopirita. Os greisens estão restritos a uma faixa estreita e a bolsões na área de contato entre os veios e as fácies graníticas da Suíte Intrusiva Alto Candeias, com a cassiterita ocorrendo de forma disseminada e associada à arsenopirita e wolframita. Os veios e greisens estão relacionadas ao intenso hidrotermalismo que imprimiu pequenas zonas de alteração hidrotermal sobre as rochas da Suíte Intrusiva Alto Candeias, principalmente ao longo dos planos de falhas e/ou fraturas e nos contatos litológicos.

A caracterização química de minerais é um procedimento amplamente utilizado no estudo petrogenético e metalogenético de sistemas graníticos portadores de mineralizações de $\mathrm{Sn}, \mathrm{W}, \mathrm{Nb}$, Ta e metais raros (Taylor 1979, Charoy 1979, Lehmann 1990, Middelaar e Keith 1990, Souza e Botelho 2009). Propostas para a caracterização genética da cassiterita, a partir da sua composição química, ou inclusões fluidas e minerais contidos, foram discutidas por diversos autores (Moore e Howie 1979, Schneider et al. 1978, Foord 1982, Murciego et al. 1987, Foord e Cook 1989, Murciego et al. 1997, Souza e Botelho 2009).

Neste capítulo, serão apresentadas e discutidas informações sobre o sistema mineralizado, bem como as composições químicas de cassiterita obtidas por meio de análises por microssonda eletrônica.

\subsection{SISTEMA DE VEIOS E VÊNULAS}

Veios e vênulas de quartzo ocorrem em falhas e/ou fraturas que cortam as rochas graníticas pertencentes à Suíte Intrusiva Alto Candeias. Em geral, são descontínuos, com espessuras e comprimentos variando de centimétricos até decamétricos, exibindo granulação média a grossa, bastante fraturados e com limites laterais marcados pelo desenvolvimento de cristais de micas (muscovita). Estão orientados segundo a direção principal NW-SE e mergulho em torno de $25^{\circ}$ para SW. Hospedam agregados maciços de cassiterita e arsenopirita euédricas a subédricas distribuídas de forma disseminada (Figuras 3.1A, 3.1B e 3.1C).

Localmente, observa-se o desenvolvimento de pequenas zonas de cisalhamento, de direção NNW-SSE, que atravessam o granito encaixante, imprimindo milonitização à rocha com desenvolvimento de arranjo microtextural marcado pelo estiramento mineral (Figuras 3.1D e 3.2A). A essas zonas associam-se veios e vênulas, além de discretas zonas de greisenização.

A associação mineralógica dos veios é composta essencialmente por quartzo-cassiteritaarsenopirita e como acessórios fluorita, pirita e hematita. O quartzo encontra-se bastante fraturado (Figura 3.2B) e a cassiterita ocorre distribuída de modo maciço e, localmente, disseminada, ocupando as porções intermediárias e internas dos veios, sob a forma de cristais subédricos a anédricos moderadamente fraturados (Figuras 3.2C e 3.2D). A cassiterita exibe marcante zoneamento, ressaltado por bandas de cores claras (variando de castanho claro a vermelho) e bandas de cores escuras (variando de castanho escuro a marrom escuro). A arsenopirita representa a principal fase mineral 
sulfetada e ocorre sob a forma de cristais disseminados e/ou agregados subédricos a euédricos (Figuras 3.1C, $3.2 \mathrm{C}$ e $3.2 \mathrm{D})$.
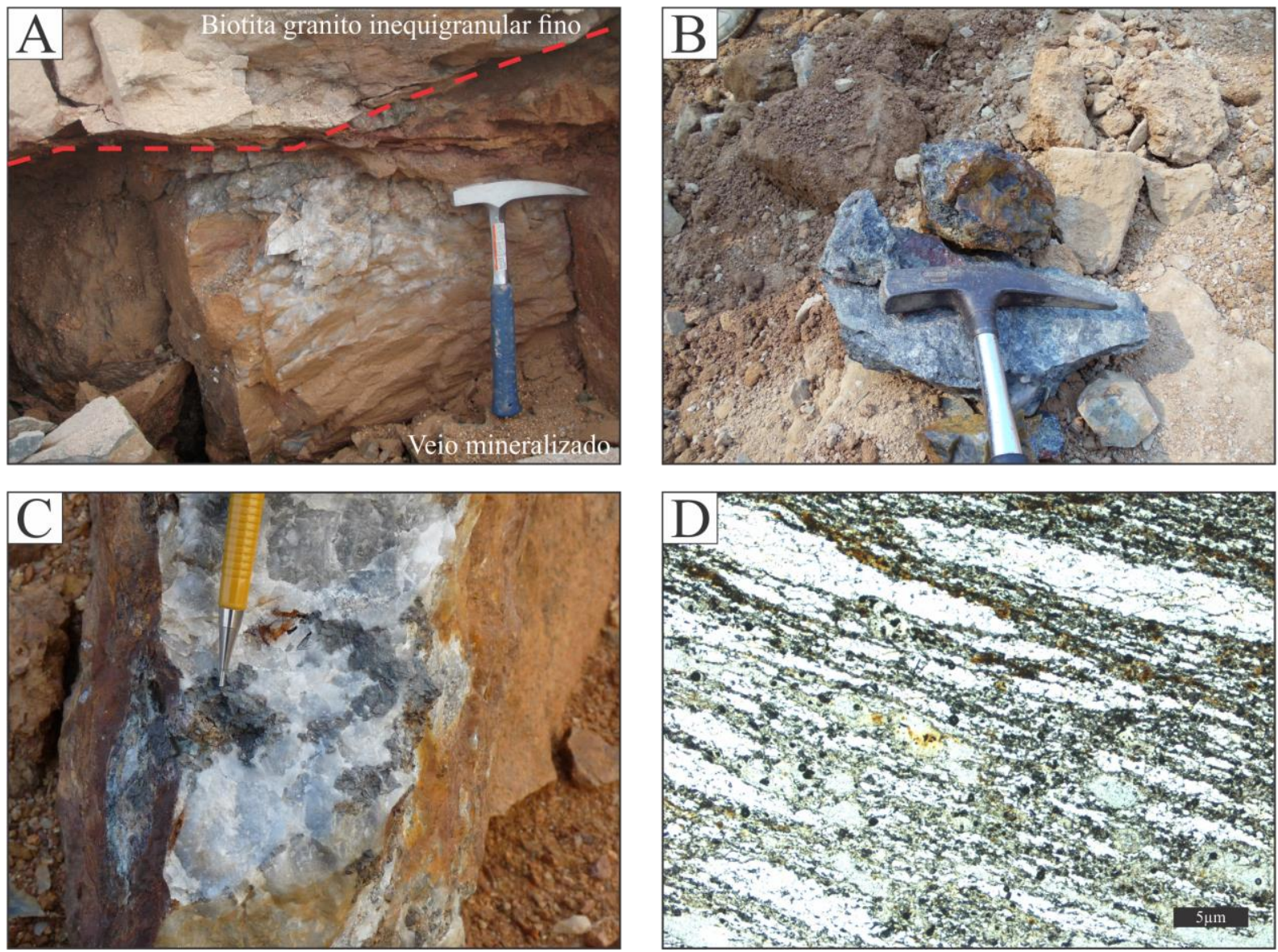

Figura 3.1. Fotografias representantes dos veios mineralizados que compõe o depósito de estanho Liberdade: A) veio mineralizado em contato com o biotita granito inequigranular fino (fácies 3); B) blocos de cassiterita maciça extraída do veio mineralizado; C) bloco do veio mineralizado com cristais de cassiterita e arsenopirita oxidada; D) fotomicrografia com nicóis paralelos de uma porção do veio, colocado em condições de cisalhamento, formando uma estruturação milonítica no mesmo.

\subsection{GREISENS DO DEPÓSITO DE ESTANHO LIBERDADE}

Os greisens do depósito de estanho Liberdade foram identificados a oeste do depósito Liberdade (Figuras 3.3A, 3.3B e 3.3C) e nos contatos dos veios mineralizados com os granitos da Suíte Intrusiva Alto Candeias (Figura 3.3D). Segundo a proposta de Kühne et al. (1972, in Stemprok 1987) essa rocha foi classificada como quartzo-muscovita greisen com fluorita (Figura 3.4).

\subsubsection{Quartzo-muscovita greisen com fluorita}

O quartzo-muscovita greisen com fluorita ocorre a oeste da mina Liberdade e ao longo da zona de contato entre os veios mineralizados e os granitos encaixantes da Suíte Intrusiva Alto Candeias. Em geral, exibe cor variando de cinza esverdeado a amarronzado, granulação fina a média, além de hospedar agregados de cristais de cassiterita distribuídos de modo disseminado ou maciço. Exibe arranjo microtextural inequigranular, onde a mineralogia principal é formada por proporções variadas de muscovita e quartzo, contendo cassiterita, arsenopirita, \pm fluorita, \pm ilmenita, \pm pirita, \pm xenotima, \pm thorita, \pm monazita. 

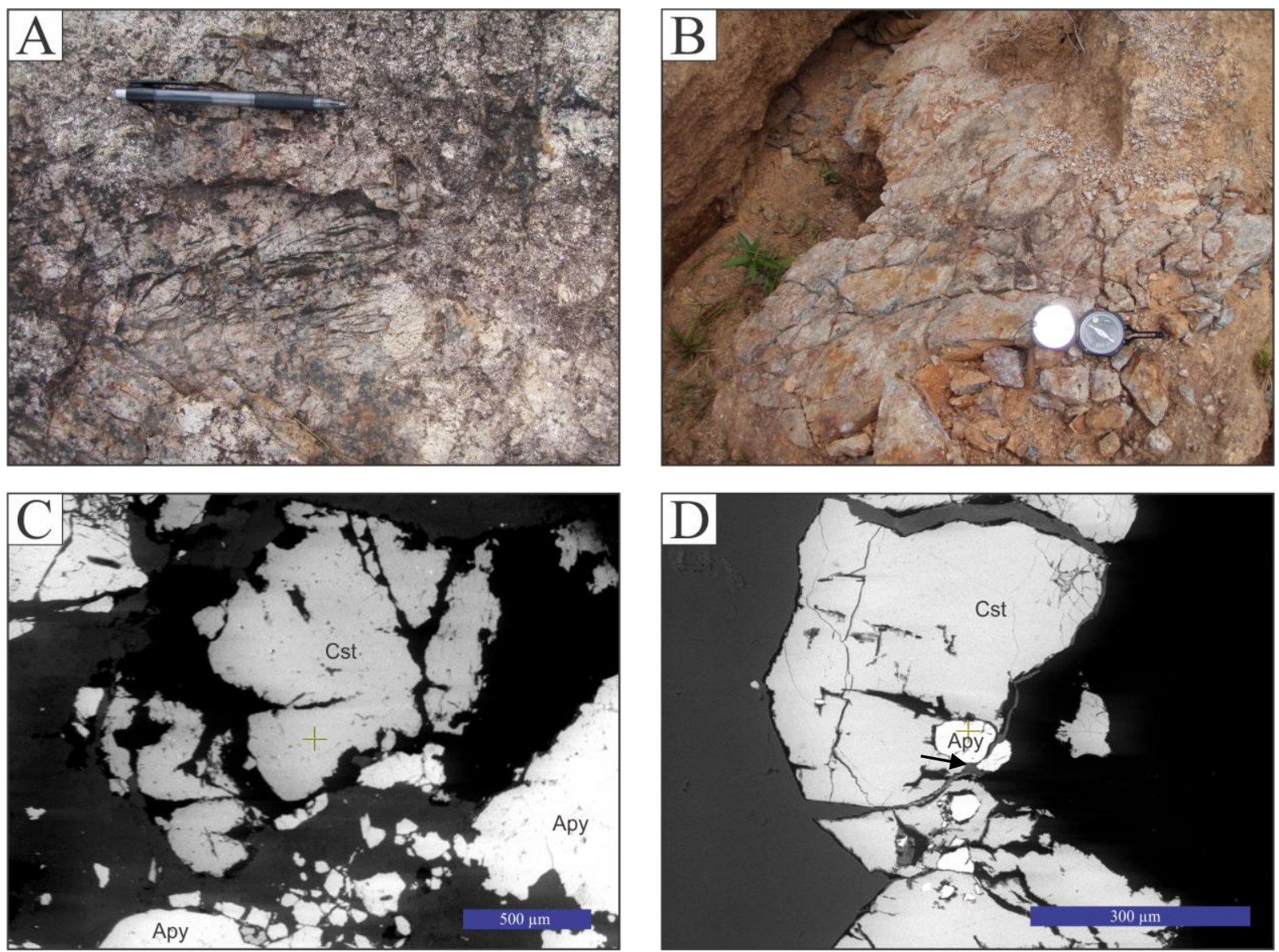

Figura 3.2. Fotografias do veio mineralizado: a) microzonas de cisalhamento mineralizadas, encontradas em pequenas fraturas no granito, em escala de afloramento; b) veio de quartzo bastante fraturado; c \& d) imagem de elétrons retro espalhados (MEV) evidenciando a relação da cassiterita com a arsenopirita. Siglas: Cst: Cassiterita; APy: Arsenopirita.

O quartzo ocorre sob a forma de cristais anédricos a subédricos, moderadamente fraturados, apresentando bordas irregulares, por vezes denteadas e exibe forte extinção ondulante. A muscovita ocorre sob a forma de agregados de cristais tabulares (Figuras 3.5A e 3.5B), associado à arsenopirita (Figuras 3.5C e 3.5D) e ilmenita (Figura 3.5C e 3.5D). Os cristais de muscovita exibem extinção ondulante e, localmente, se mostram retorcidos formando feições do tipo kink bands, evidenciando a tensão a que esse mineral foi exposto.

A fluorita ocorre de forma disseminada e, em geral, são cristais subédricos a euédricos, pouco fraturados. A cassiterita ocorre sob a forma de cristais subédricos, em geral, mostra-se fraturada (Figuras 3.6A e 3.6B) e ocorrem distribuídos em agregados maciços ou disseminados. Investigações através de MEV (microscopia eletrônica de varredura) revelaram que a cassiterita raramente possui micro inclusões ou exsoluções de outros minerais, exceto ao longo de fraturas, as quais são frequentemente preenchidas por minerais sulfetados (geralmente arsenopirita e pirita; Figura 3.6D).

Do mesmo modo como ocorrem nos veios, a cassiterita no greisen exibe marcante zoneamento, ressaltado por bandas de cores claras (variando de castanho claro a vermelho) e bandas de cores escuras (variando de castanho escuro a marrom escuro; Figuras 3.6C e 3.6D).

Associado à mineralogia principal ocorre ainda, distribuída de modo disseminado e/ou formando pequenos agregados, a seguinte associação mineral: arsenopirita, pirita, ilmenita, xenotima, thorita, monazita e allanita. Cristais de zircão também são encontrados no quartzo-muscovita greisen, os quais devem ser herdados dos granitos encaixantes pertencentes a Suíte Intrusiva Alto Candeias. 

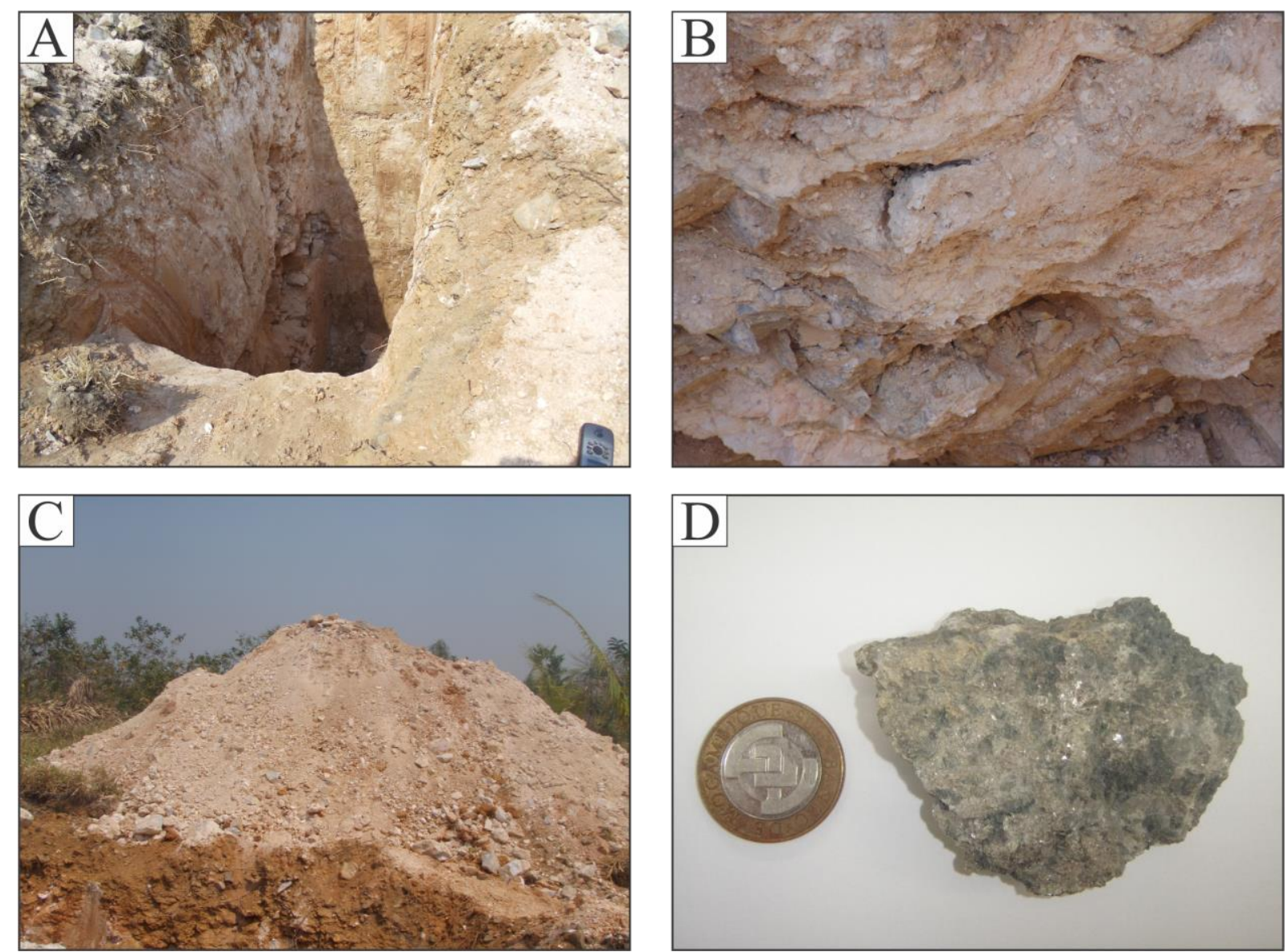

Figura 3.3. Fotografias do quartzo-muscovita greisen com fluorita dentro da área do depósito de estanho Liberdade: a, b \& c) material da cúpula greisenizada totalmente alterada; d) amostra do quartzomuscovita greisen com fluorita retirado do contato entre o veio mineralizado e a rocha encaixante pertencente a SIAC.

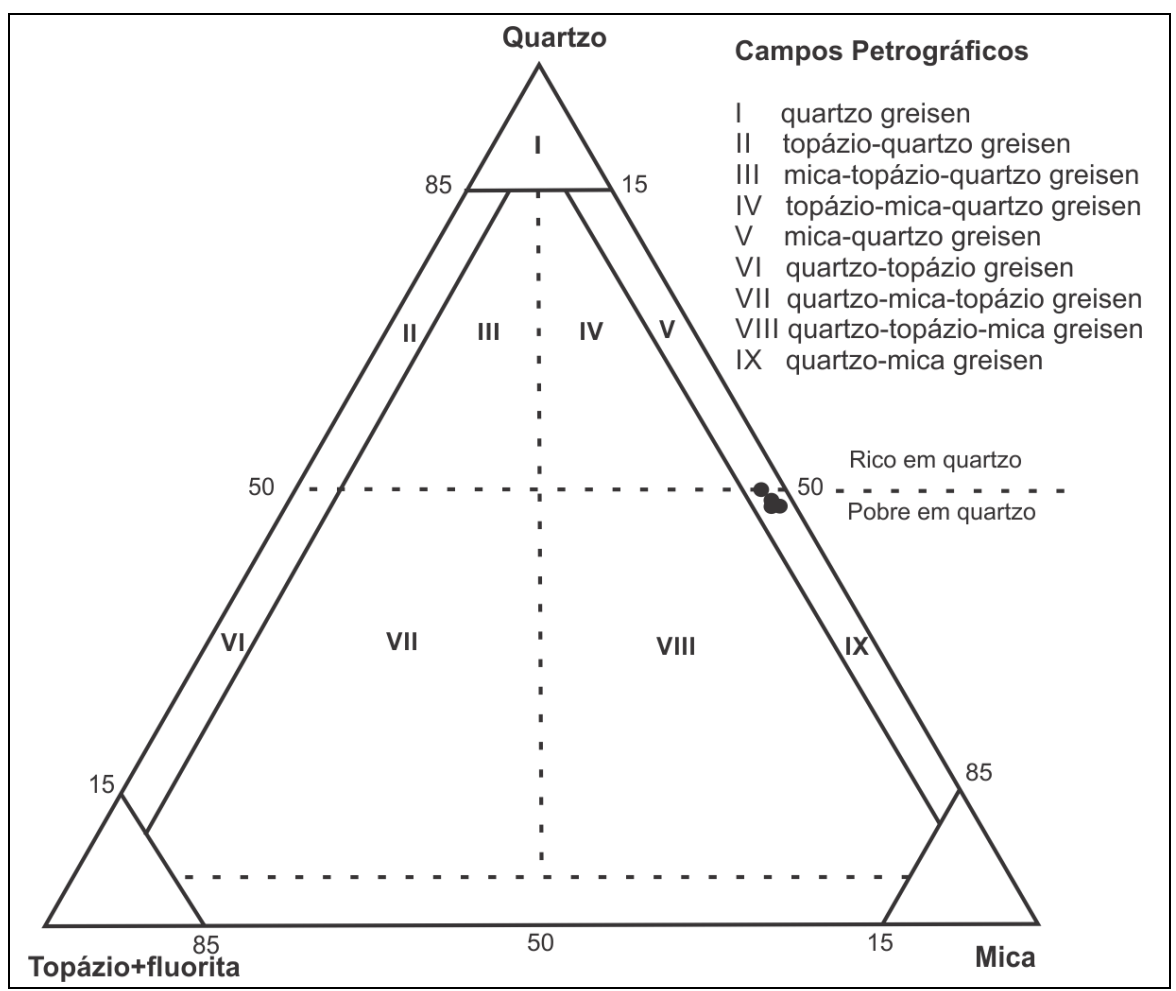

Figura 3.4. Diagrama de classificação de greisens de Kühne et al. (1972, in Stemprok 1987). 

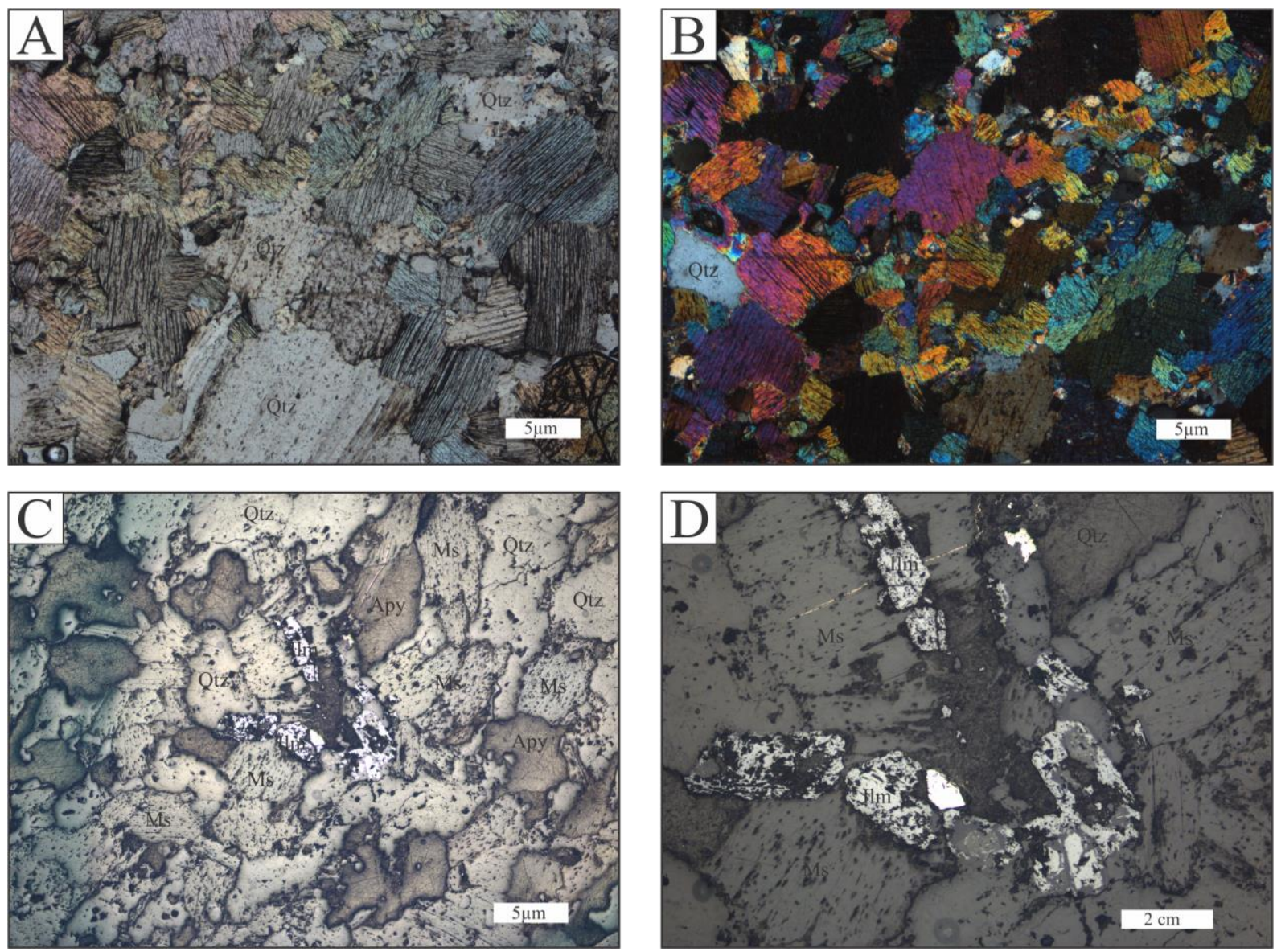

Figura 3.5. Fotomicrografias do quartzo-muscovita greisen com fluorita mapeado dentro da área do depósito de estanho Liberdade: A) trama do greisen, evidenciando a relação quartzo-muscovita e muscovitamuscovita; B) mesma fotomicrografia exibida em A, porém com os nicóis cruzados; C e D) relações da ilmenita e arsenopirita com os cristais de muscovita. Siglas: APy: Arsenopirita; Ilm: Ilmenita; Ms: Muscovita; Qtz: Quartzo.

Sendo assim, a paragênese mineral exibe feições diagnósticas de uma cronologia na cristalização mineral, controlada principalmente pelo abaixamento da temperatura (Figura 3.7). Observações petrográficas demonstram haver estágios sequenciados de precipitação do conteúdo metálico e formação da paragênese mineral no greisen do depósito de estanho Liberdade.

A associação arsenopirita-pirita representa a principal fase mineral sulfetada. A arsenopirita ocorre sob a forma de cristais disseminados e/ou agregados subédricos a euédricos (Figuras 3.8A e 3.8B), moderadamente fraturados, exibindo, localmente, franca piritização. A pirita ocorre sob a forma de cristais disseminados, euédricos a subédricos, sempre associados à arsenopirita (Figura 3.8C).

A ilmenita ocorre sob a forma de cristais disseminados, alongados, subédricos e associados ao quartzo e a muscovita (Figuras 3.5C e 3.5D), apresentando exsoluções de titanita em suas porções centrais (Figura 3.8D). A xenotima ocorre sob a forma de cristais disseminados, subédricos a anédricos, associados à arsenopirita e com inclusões de thorita em seus cristais (Figuras 3.8E e 3.8F). 

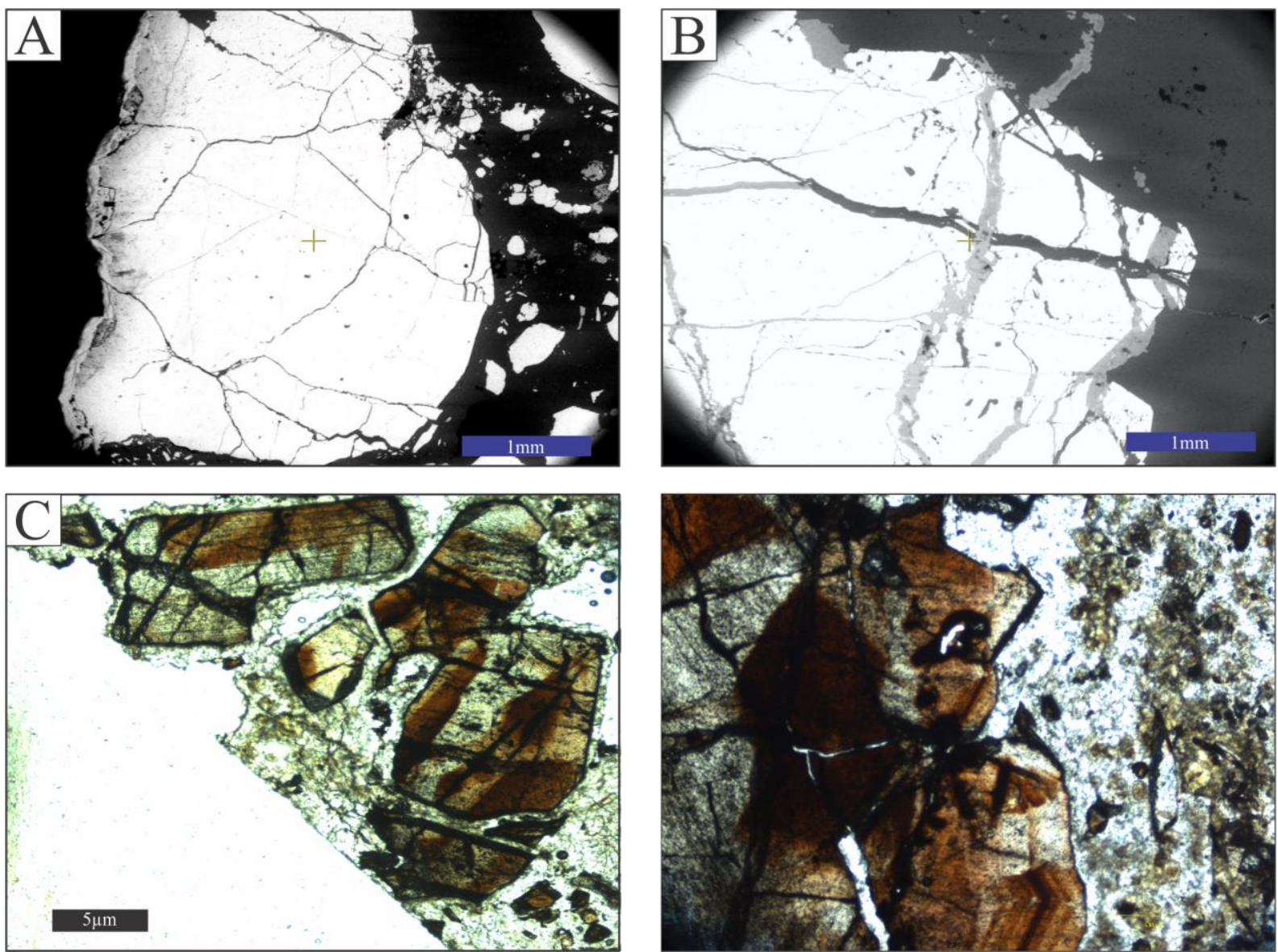

Figura 3.6. Fotomicrografias mostrando cristais de cassiterita do quartzo-muscovita greisen com fluorita: a \& b) imagem de elétrons retroespalhados (MEV) mostrando cristais de cassiterita fraturados, onde as fraturas estão preenchidas por sulfetos (arsenopirita e pirita); c \& d) cristais de cassiterita fraturados e apresentando zoneamento.

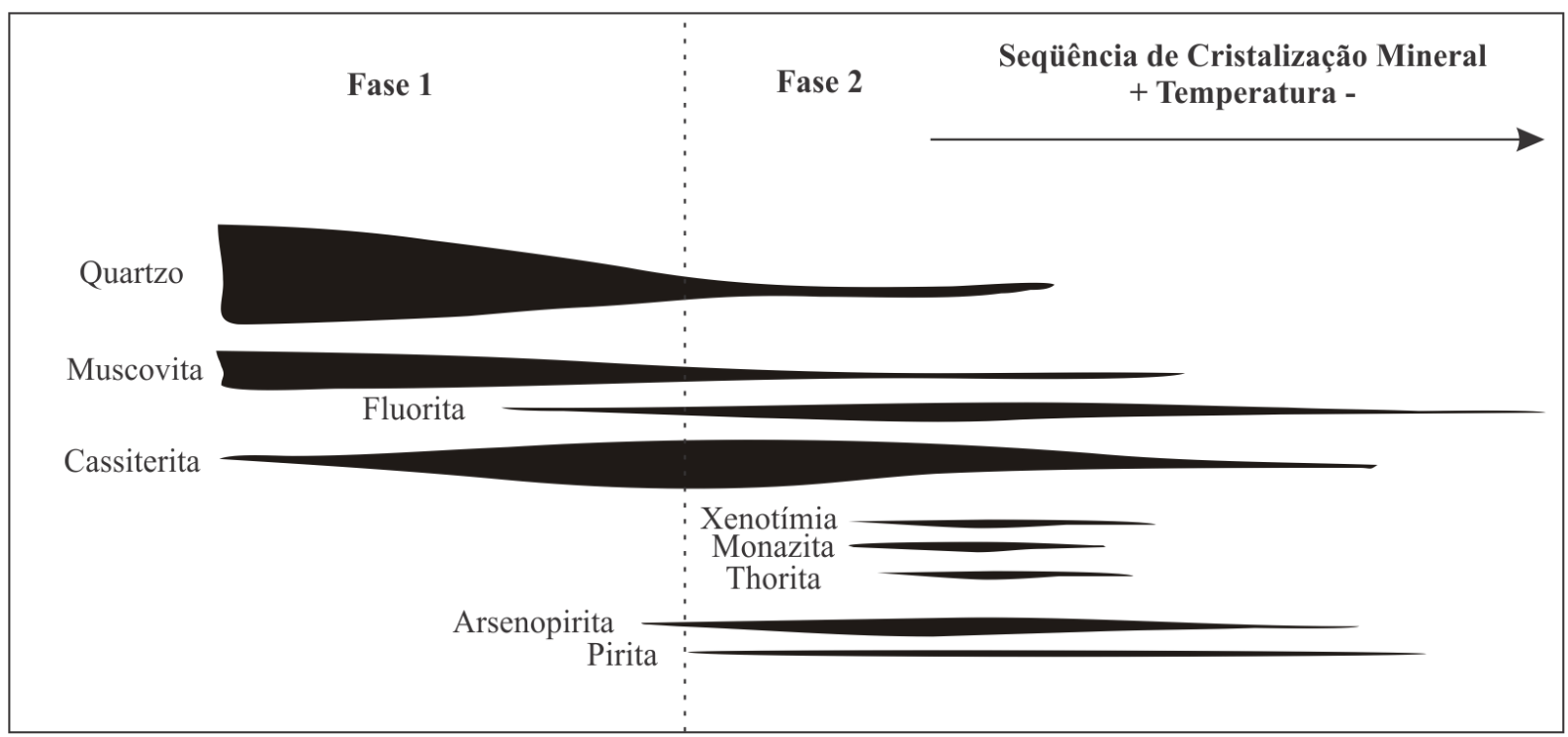

Figura 3.7. Sequência esquemática de cristalização mineral no quartzo-muscovita greisen com fluorita do depósito de estanho Liberdade. 

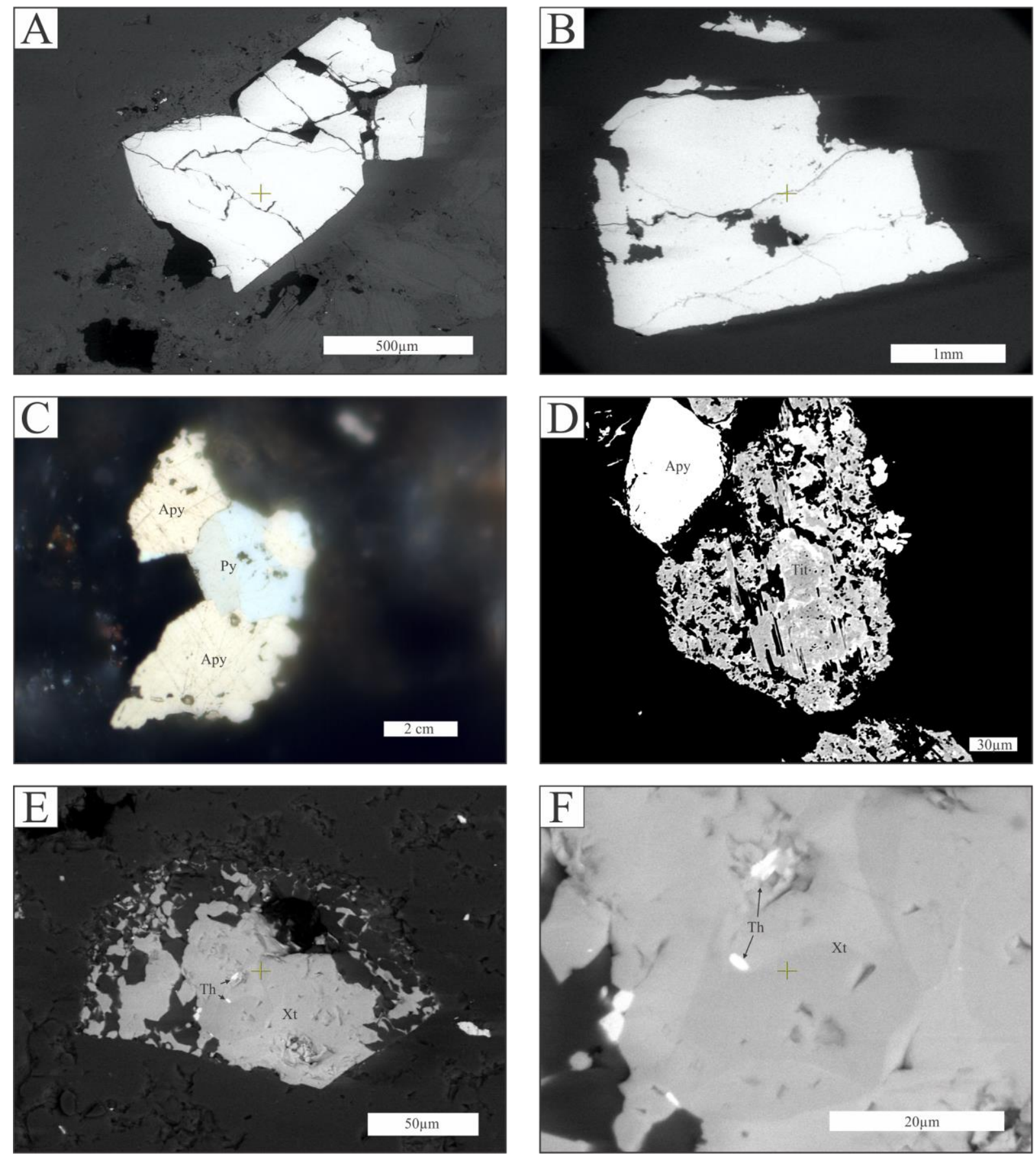

Figura 3.8. Fotomicrografias mostrando as relações entre os minerais do greisen: A e B) imagem de elétrons retroespalhados (MEV) mostrando cristais de arsenopirita moderadamente fraturados; C) fotomicrografia mostrando a associação arsenopirita-pirita; D) imagem de elétrons retro espalhados (MEV) mostrando cristal de ilmenita apresentando exsolução de titanita. E e F) Imagem de elétrons retroespalhados (MEV) mostrando a relação da xenotímia com a thorita. Notar que a thorita apresenta seus cristais sob a forma de inclusões na xenotímia.Siglas: APy: Arsenopirita; Py: Pirita; Tit: Titanita; Xt: Xenotímia; Th: Thorita.

\subsection{SEDIMENTOS ALUVIAIS E COLUVIAIS MINERALIZADOS}

Os depósitos sedimentares colúvio-aluviais estão distribuídos ao longo de paleocanais nas imediações do depósito de estanho Liberdade, sendo explorados sob a forma de garimpos (Figura 3.9). 
Metalogênese do Depósito de Estanho Liberdade, Campo Novo de Rondônia - RO

Paulo Sérgio Mendes dos Santos Júnior
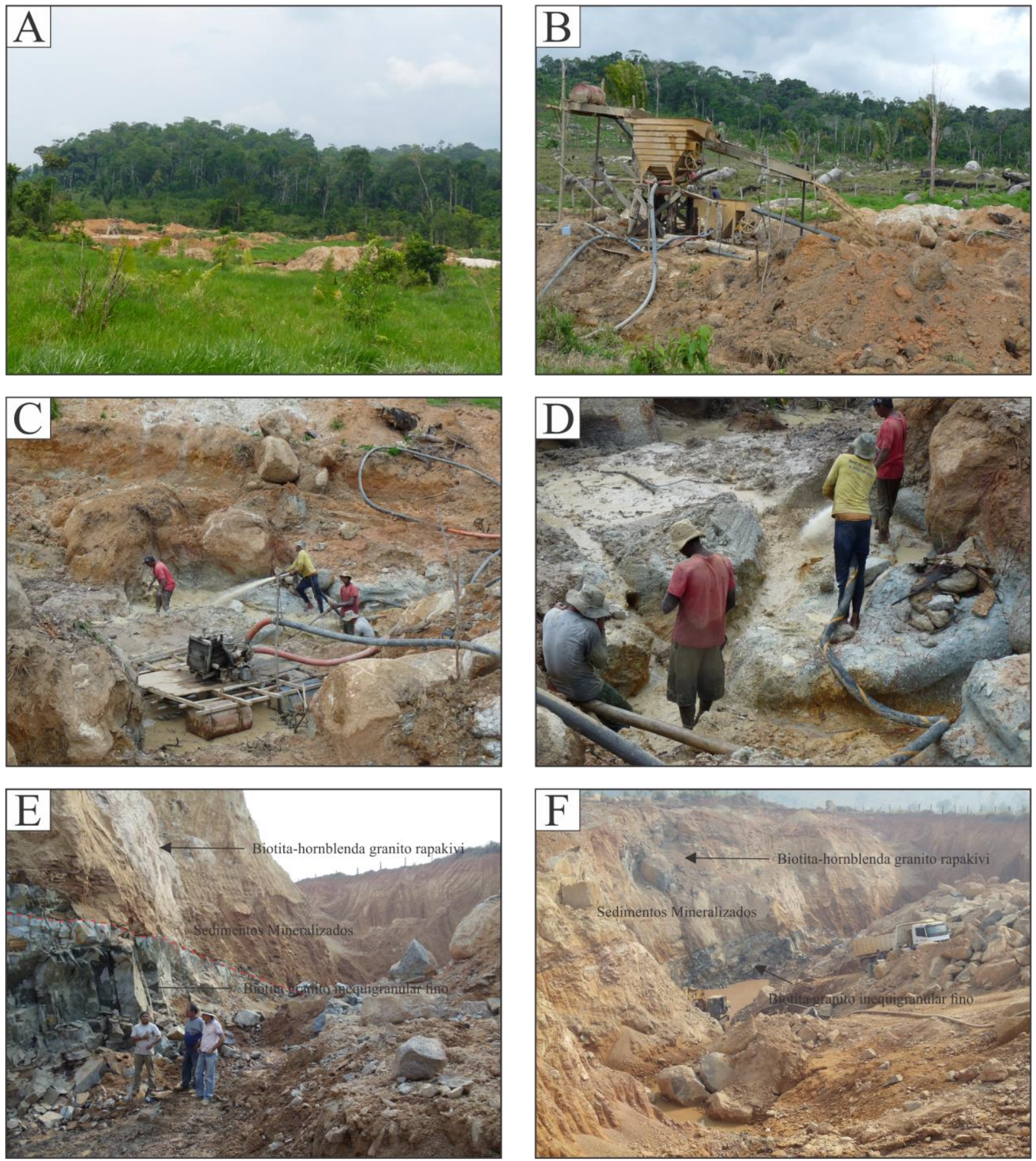

Figura 3.9. Fotografias de garimpo e sedimentos colúvio-aluvionares: A) região de garimpo; B) planta de concentração utilizada pela lavra garimpeira; C e D) visão da área lavrada por garimpeiros, onde estão explotando um material arenoso, areno-argiloso e argilo-arenoso, ricos em cassiterita; E e F) visão geral de uma das cavas da mina Liberdade, onde percebe-se um contato brusco dos sedimentos coluvionares mineralizados com o biotita granito inequigranular fino.

Os paleocanais são caracterizados pela intercalação de níveis arenosos, argilo-arenosos e conglomeráticos com matacões. Este pacote de sedimentos inconsolidado apresenta cores diversas e uma espessura que varia de 3 a $5 \mathrm{~m}$, onde a cassiterita tende a estar concentrada nos níveis mais basais representados por conglomerados e matacões. 


\subsection{GEOMETRIA DO SISTEMA DE VEIOS}

O depósito de estanho Liberdade está localizado entre duas zonas de cisalhamento principais de direção NW-SE, definidas como Falha Jaci Paraná (a sul do depósito, no contato das rochas da Suíte Intrusiva Alto Candeias com rochas das formações Nova Floresta e Palmeiral) e Zona de Cisalhamento Montenegro (a norte do depósito, no contato das rochas da Suíte Intrusiva Alto Candeias com rochas da Suíte Intrusiva Rio Crespo; Quadros 2007). No entorno do depósito de estanho Liberdade, através do estudo de imagens de satélites e geofísicas, bem como as relações de campo, foram visualizadas zonas de cisalhamento subordinadas, relacionadas às zonas de cisalhamento principais NW-SE, interpretadas como zona de cisalhamento sinistral, aqui definida como Zona de Cisalhamento Liberdade. No sistema de veios do depósito de estanho Liberdade predominam feições de caráter rúptil-dúctil, onde o sistema de cisalhamento é caracterizado como do tipo transcorrente rúptil-dúctil, segundo a classificação de Ramsey (1980). As principais feições estruturais do depósito são representadas por falhas e fraturas preenchidas por veios de espessuras variáveis (centimétricas a decamétricas) e, quando vistas em conjunto, formam faixas de cisalhamento, preenchidas por cassiterita com espessuras centimétricas (em torno de 80 a $100 \mathrm{~cm}$ de cassiterita maciça).

Os corpos mineralizados do depósito de estanho Liberdade constituem um enxame de veios, hospedados nos granitos da Suíte Intrusiva Alto Candeias, encaixados em uma zona de cisalhamento transcorrente sinistral, de direção NW-SE $\left(247^{\circ} / 25^{\circ}\right)$. Veios menores de direção NE-SW também ocorrem, sendo interpretados como fraturas de extensão do tipo $\mathrm{T}$ ou fraturas tipo gashes, segundo a classificação de Riedel (1929). Conforme já informado anteriormente, as estruturas mineralizadas mostram duas direções principais: o primeiro trend representa a direção principal onde a faixa mineralizada em cassiterita foi estabelecida e onde se desenvolveu o corpo mineralizado do depósito de estanho Liberdade; o segundo trend corresponde a fraturas menores que foram mineralizadas. $\mathrm{O}$ padrão geométrico das duas direções de filões mineralizados, é compatível com o modelo sinistral de Riedel, onde a direção principal da mineralização (NW-SE) corresponde às estruturas Y(D) enquanto que a segunda direção da mineralização corresponde a fraturas de extensão do tipo $\mathrm{T}$ ou fraturas tipo gashes (Figuras 3.10A e 3.10B).

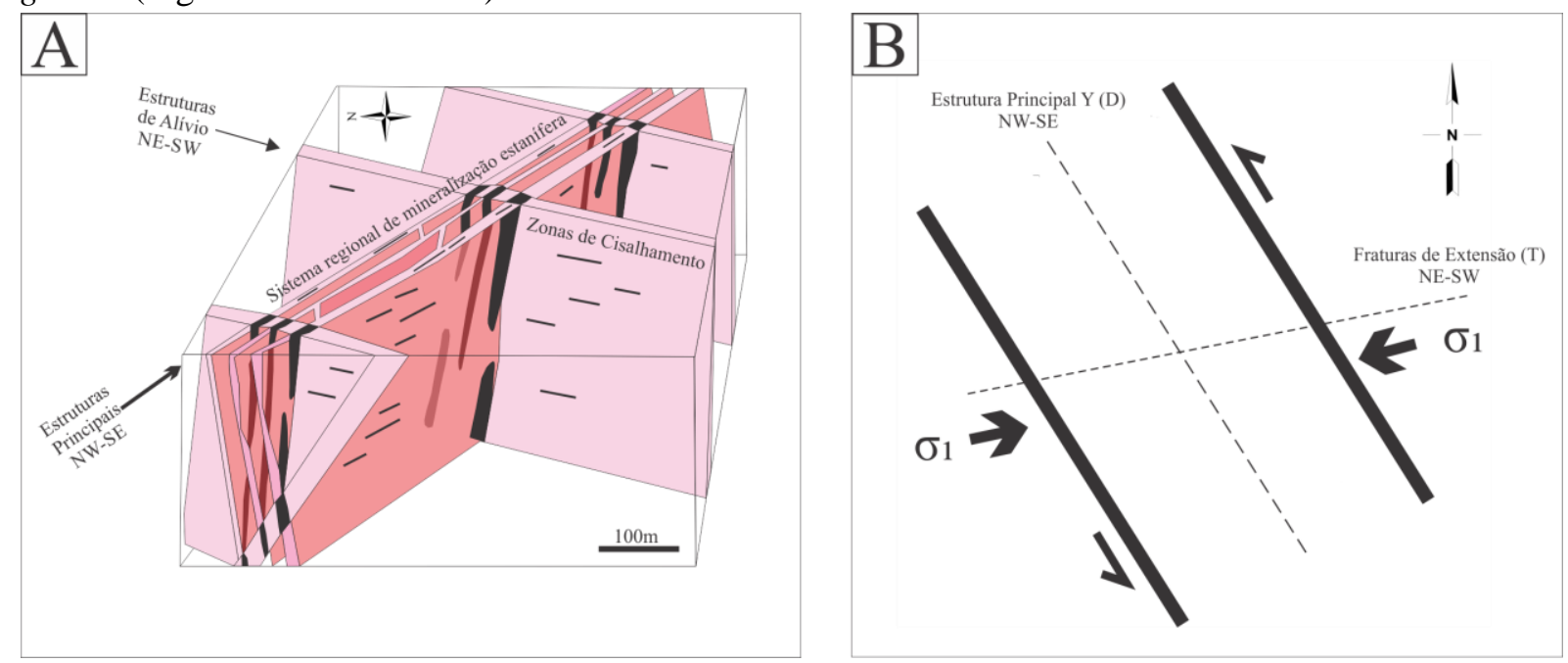

Figura 3.10. Modelos estruturais propostos para a região do depósito de estanho Liberdade: A) Interpretação em bloco diagrama do aspecto geral da geometria dos veios mineralizados do depósito de estanho Liberdade; B) Modelo de Riedel simplificado para as fraturas do Depósito de Estanho Liberdade.

Nas interseções entre as duas direções ocorrem corpos em forma de charutos verticalizados (bolsões), onde ocorre minério de mais alto teor, devido ao maior fluxo hidrotermal nessa zona (Figura $3.10 \mathrm{~A})$. 
Os veios gashes ou do tipo $\mathrm{T}$ representam um importante indicador cinemático, pois preenchem fraturas de extensão $(\mathrm{T})$ que se posicionam na direção da tensão compressiva máxima $\left(\sigma_{1}\right)$ do cisalhamento (Figura 3.10B), formando fraturas abertas que foram preenchidas pelos fluidos mineralizantes.

O cisalhamento não só controlou o alojamento dos veios mineralizados como também a greisenização. As falhas e fraturas do cisalhamento representaram as vias por onde circularam os fluidos mineralizantes que depositaram os veios mineralizados e também resultaram na formação da greisenização, por meio da interação fluido-rocha.

\subsection{QUÍMICA MINERAL DA CASSITERITA}

Para estudos de química mineral, foi escolhida a cassiterita objetivando saber o grau de pureza de estanho dentro do óxido, bem como suas possíveis contaminações, pois, como a mineração de cassiterita está em alta, logo se faz necessário a caracterização da mesma.

Sendo assim, a cassiterita, tanto nos veios quanto nos greisens, ocorre sob a forma de agregados de cristais euédricos a subédricos, zonados, moderadamente fraturados e desenvolvidos junto aos cristais de quartzo e arsenopirita (Figura 3.11). Na cassiterita a concentração de $\mathrm{SnO}_{2}$ varia de 98,615 a $99,785 \%$, enquanto que os metais $\mathrm{W}, \mathrm{Nb}$, Ti e Fe, ocorrem em concentrações muito baixas, ou seja, na ordem de traços (Tabela 3.1).

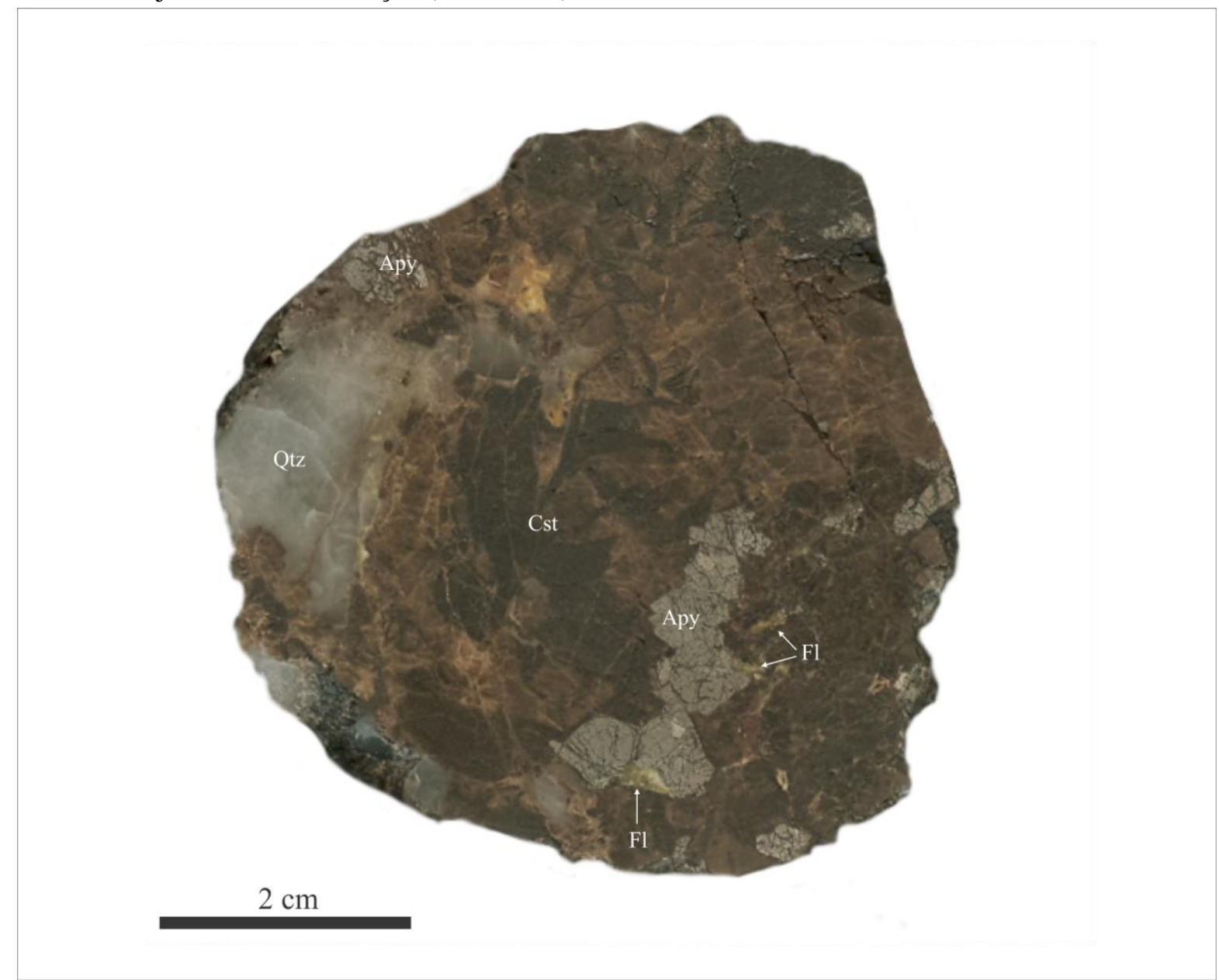

Figura 3.11. Amostra de cassiterita do veio mostrando sua relação com a arsenopirita, fluorita e quartzo. Siglas: Cst: Cassiterita; APy: Arsenopirita; Qtz: quartzo; Fl: Fluorita

A zonação nessa cassiterita é caracterizada pela alternância de zonas cujas cores variam de vermelho, castanho claro, castanho escuro, marrom até marrom escuro (Figura 3.12). As análises 
químicas revelaram que as zonas mais claras (castanho claro e vermelho) são mais enriquecidas em $\mathrm{SnO}_{2}$ e empobrecidas em $\mathrm{FeO}_{\text {(total) }}, \mathrm{TiO}_{2}, \mathrm{Nb}_{2} \mathrm{O}_{5}$ e $\mathrm{WO}_{3}$, enquanto que as zonas mais escuras (castanho escuro a marrom escuro) são enriquecidas em $\mathrm{FeO}_{\text {(total) }}, \mathrm{TiO}_{2}, \mathrm{Nb}_{2} \mathrm{O}_{5}$ e $\mathrm{WO}_{3}$, e empobrecidas em $\mathrm{SnO}_{2}$ (Tabela 3.1; Figura 3.12). Este comportamento é similar aos resultados conhecidos sobre a composição química de cristais zonados de cassiterita em outros depósitos de estanho, onde as zonas de cores mais claras são também mais puras em $\mathrm{SnO}_{2}$ (Giuliani 1987, Neiva 1996, Murciego et al. 1997, Costi et al. 2000, Souza e Botelho 2009).

Tabela 3.1. Dados das análises por microssonda eletrônica em cristais de cassiterita. Composições dos óxidos em $\%$ em peso e dos elementos em átomos por fórmula unitária, calculada na base de 2 oxigênios para cassiterita.

\begin{tabular}{ccccccc}
\hline Amostras & $\mathbf{W O}_{\mathbf{3}}$ & $\mathbf{F e O}$ & $\mathbf{T i O}_{\mathbf{2}}$ & $\mathbf{N b}_{\mathbf{2}} \mathbf{O}_{\mathbf{5}}$ & $\mathbf{S n O}_{\mathbf{2}}$ & $\mathbf{T O T A L}$ \\
\hline 1 & 0,0000 & 0,0000 & 0,0113 & 0,0000 & 99,7850 & 99,7963 \\
2 & 0,0000 & 0,0120 & 0,1090 & 0,0000 & 99,5530 & 99,6740 \\
3 & 0,0000 & 0,0340 & 0,2560 & 0,0700 & 99,0490 & 99,4090 \\
4 & 0,0000 & 0,0130 & 0,1420 & 0,0684 & 99,4060 & 99,6294 \\
5 & 0,0150 & 0,0810 & 0,2840 & 0,2570 & 98,9540 & 99,5910 \\
6 & 0,0190 & 0,0900 & 0,4890 & 0,3510 & 98,6150 & 99,5640 \\
7 & 0,0100 & 0,0780 & 0,2680 & 0,2570 & 98,9740 & 99,5870 \\
8 & 0,0120 & 0,0750 & 0,2430 & 0,1400 & 98,9830 & 99,4530 \\
9 & 0,0000 & 0,0200 & 0,1140 & 0,0000 & 99,4920 & 99,6260 \\
10 & 0,0000 & 0,0270 & 0,1280 & 0,1640 & 99,2140 & 99,5330 \\
11 & 0,0000 & 0,0100 & 0,0890 & 0,0000 & 99,3760 & 99,4750 \\
\hline
\end{tabular}

\begin{tabular}{ccccccc}
\hline \multicolumn{7}{c}{ Fórmula estrutural na base de 2 oxig. } \\
\hline Amostras & $\mathbf{W}$ & $\mathbf{F e}$ & $\mathbf{T i}$ & $\mathbf{N b}$ & $\mathbf{S n}$ & Total \\
\hline 1 & 0,000000 & 0,000000 & 0,000213 & 0,000000 & 0,999787 & 1,000000 \\
2 & 0,000000 & 0,000252 & 0,002062 & 0,000000 & 0,997812 & 1,000126 \\
3 & 0,000000 & 0,000716 & 0,004847 & 0,000796 & 0,993800 & 1,000159 \\
4 & 0,000000 & 0,000273 & 0,002685 & 0,000777 & 0,996206 & 0,999942 \\
5 & 0,000098 & 0,001700 & 0,005362 & 0,002916 & 0,989998 & 1,000072 \\
6 & 0,000123 & 0,001885 & 0,009214 & 0,003974 & 0,984691 & 0,999887 \\
7 & 0,000065 & 0,001637 & 0,005060 & 0,002916 & 0,990378 & 1,000057 \\
8 & 0,000078 & 0,001578 & 0,004598 & 0,001592 & 0,992506 & 1,000352 \\
9 & 0,000000 & 0,000421 & 0,002157 & 0,000000 & 0,997633 & 1,000210 \\
10 & 0,000000 & 0,000568 & 0,002422 & 0,001865 & 0,994963 & 0,999818 \\
11 & 0,000000 & 0,000211 & 0,001687 & 0,000000 & 0,998208 & 1,000105 \\
\hline
\end{tabular}

Nos diagramas de correlação entre $\mathrm{SnO}_{2} \times \mathrm{FeO}_{\text {(total) }}, \mathrm{Nb}_{2} \mathrm{O}_{5}$ e $\mathrm{WO}_{3}$, observa-se a tendência de formação de trends decrescentes, caracterizados pelo aumento no conteúdo de $\mathrm{SnO}_{2}$ com a diminuição nos conteúdos de $\mathrm{FeO}_{\text {(total) }}, \mathrm{Nb}_{2} \mathrm{O}_{5}$ e $\mathrm{WO}_{4}$, demostrando haver diferentes razões de substituições entre esses compostos nas zonas de cores mais claras e mais escuras (Figura 3.13). O principal mecanismo responsável por essas substituições pode ser expresso através da equação $3 \mathrm{Sn}^{4+} \leftrightarrow 2(\mathrm{Nb})^{5+}+\mathrm{Fe}^{2+}$, onde o Fe é a principal impureza na estrutura da cassiterita. Como o conteúdo de $\mathrm{WO}_{3}$ também tende a variar diretamente proporcional ao conteúdo de $\mathrm{FeO}_{\text {(total), }}$, considera-se que o $\mathrm{W}$ também participa da substituição entre Sn e Fe, formando uma wolframita molecular, cujo mecanismo é expresso pela 
equação $2 \mathrm{Sn}^{4+} \leftrightarrow \mathrm{W}^{6+}+\mathrm{Fe}^{2+}$. Por outro lado, o $\mathrm{Nb}$ entra como impureza, principalmente nas zonas de cores mais escuras, através de substituições acopladas (Möller et al. 1988, Murciego et al. 1997).
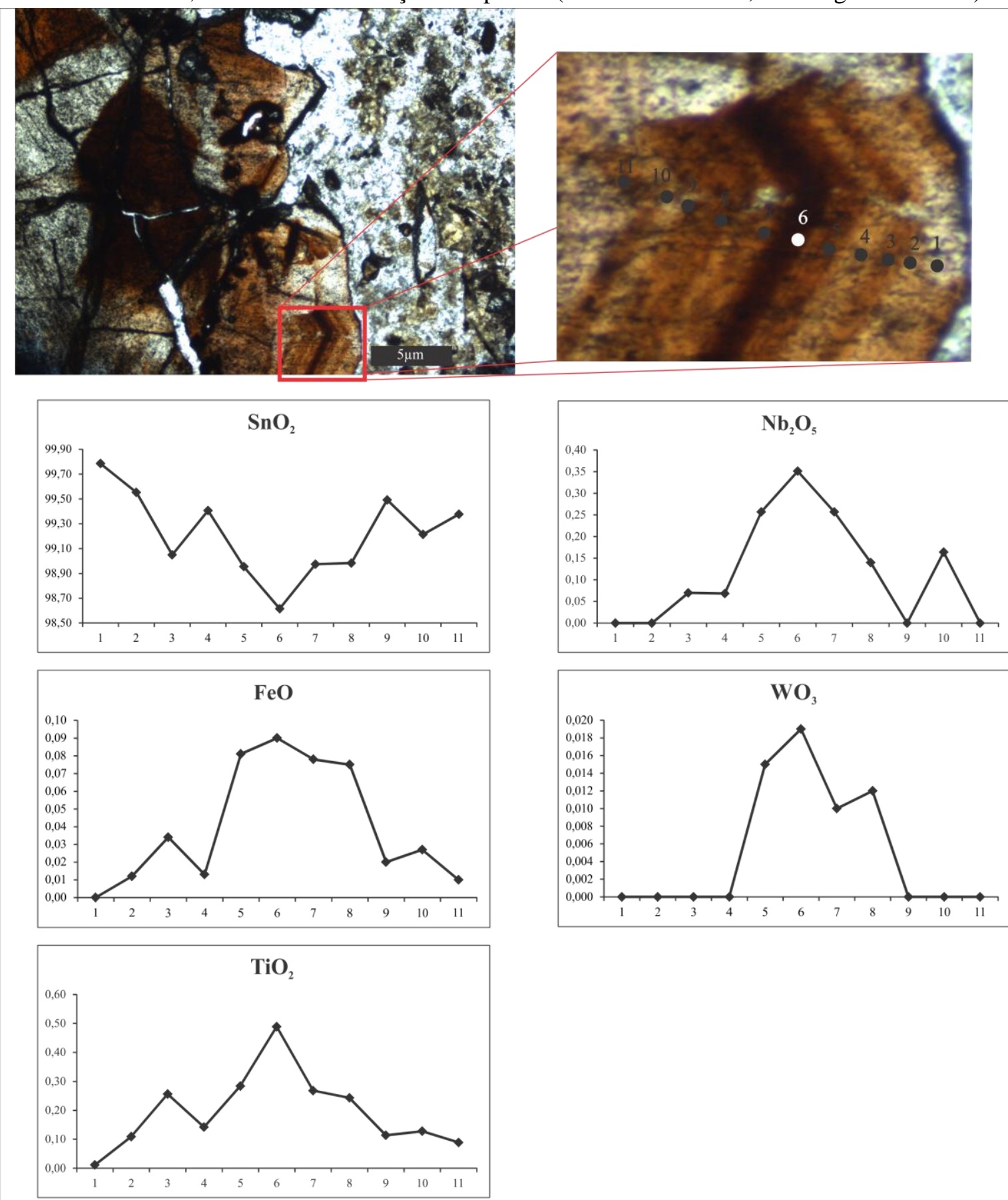

Figura 3.12. Sequência de análises pontuais por microssonda eletrônica em cristais de cassiterita zonados mostrando as variações na composição química para óxidos em \% em peso.

O conteúdo de Ta nas amostras não foi detectado ou está abaixo do limite de detecção do aparelho utilizado, sendo o conteúdo de $\mathrm{Nb}_{2} \mathrm{O}_{5}$ muito superior ao conteúdo de $\mathrm{Ta}_{2} \mathrm{O}_{5}$, o que, segundo os parâmetros estabelecidos por Möller et al. (1988), pode ser atribuído a três fatores: a) maior abundância natural de $\mathrm{Nb}$ em relação ao Ta; b) tendência do $\mathrm{Nb}^{4+}$ entrar na estrutura desordenada do rutilo; e c) a preferência do Ta pelo estado de oxidação pentavalente. Esse desequilíbrio entre os conteúdos de $\mathrm{Nb}$ e Ta é considerado como o principal motivo para explicar a variação no conteúdo de $\mathrm{TiO}_{2}$ nas cassiteritas. 

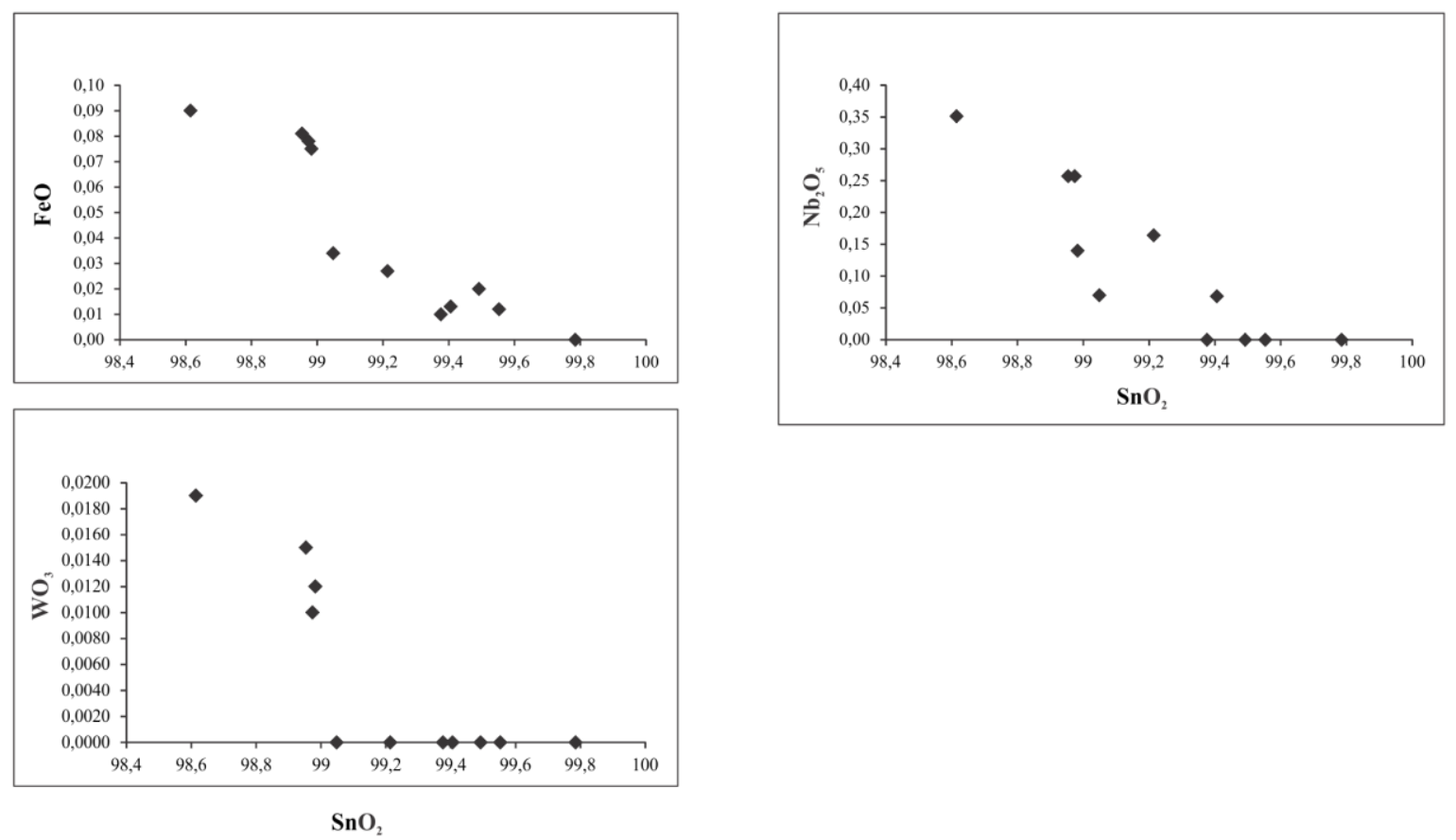

Figura 3.13. Diagramas de correlações aplicados às cassiteritas de veio, mostrando a variação nos conteúdos de $\mathrm{FeO}_{\text {(total) }}, \mathrm{Nb}_{2} \mathrm{O}_{5}$ e $\mathrm{WO}_{3}$, em relação ao conteúdo de $\mathrm{SnO}_{2}$.

Em geral, observa-se que na zonação das cassiteritas o aumento no conteúdo de $\mathrm{FeO}_{\text {(total) }}$ é acompanhado da diminuição no conteúdo de $\mathrm{TiO}_{2}$. Segundo Neiva (1996), a progressiva diminuição do Ti com o aumento de $\mathrm{Fe}+\mathrm{Nb}+\mathrm{W}$ nas cassiteritas, pode ser expresso através das equações $\mathrm{Nb}^{5+}+$ $\mathrm{Fe}^{3+} \leftrightarrow 2 \mathrm{Ti}^{4+} \mathrm{e} \mathrm{W}^{6+}+\mathrm{Fe}^{2+} \leftrightarrow 2 \mathrm{Ti}^{4+}$.

\subsection{DISCUSSÕES}

No depósito de estanho Liberdade a mineralização está hospedada em greisens, veios e vênulas, produto da ação de fluidos hidrotermais tardi a pós-magmáticos e da interação fluido-rocha encaixante, conforme modelos genéticos discutidos por Taylor (1979) e Lehmann (1990).

Segundo Plimer (1987), a formação de greisens e veios é controlada pela pressão exercida pela fase fluida exsolvida do magma residual (Pin), pela componente ao longo do eixo de tensão mínima $\left(\sigma_{3}\right)$ e pela tensão de ruptura da rocha encaixante $(\mathrm{t})$. Quando Pin $<\sigma_{3}+\mathrm{t}$, a fase fluida é aprisionada por um longo período de tempo, permitindo que o abaixamento da temperatura favoreça o desenvolvimento de reações tarde a pós-magmáticas, gerando os greisens. Por outro lado, quando Pin $>\sigma_{3}+\mathrm{t}$, o alívio da sobre pressão fluidal ocorre através do fraturamento hidráulico, acompanhado da percolação de fluidos ao longo das fraturas extensionais com a posterior formação dos veios. As transformações hidrotermais tarde a pós-magmáticas associadas ao alojamento de granitos ácidos a ultra ácido em níveis crustais rasos ocorrem a temperaturas entre 400 e $250{ }^{\circ} \mathrm{C}$ e pressões de 2 a 0,5 kbar. Tais transformações podem se desenvolver de modo generalizado ao longo das zonas de contatos litológicos ou restrita a zonas de falhas e fraturas que atravessam a rocha encaixante. Esse processo implica um conjunto de complexas reações físico-químicas, que favorecem a extração e deposição de elementos químicos maiores e traços responsáveis pela formação do depósito mineral. Dependendo das condições de pressão, temperatura, $\mathrm{pH}, \mathrm{Eh}, f \mathrm{O}_{2}$, composição do fluido hidrotermal magmático e da natureza da rocha encaixante, diferentes tipos de zonas de alteração metassomática podem ser progressivamente geradas (Scherba 1970a, Scherba 1970b, Groves e McCarthy 1978, Stemprok 1987, Pollard e Taylor 1986). 
No caso do depósito de estanho Liberdade a presença conjunta de greisen e veios revelam que a pressão da fase fluida exsolvida evoluiu com o tempo. Em um primeiro estágio, a Pin se comportou de modo inferior a $\sigma_{3}+\mathrm{t}$, ou seja, Pin $<\sigma_{3}+\mathrm{t}$ (Plimer 1987), gerando greisens no ápice da intrusão granítica. Porém, o aumento progressivo da Pin, aliada a natureza da rocha encaixante, formada por litologias distintas e com anisotropias pretéritas (falhas e fraturas), proporcionou o brusco relaxamento da sobre pressão fluidal, gerando famílias de fraturas que deram origem aos sistemas de veios.

É importante salientar que o depósito está localizado em um corredor estrutural formado por zonas de cisalhamento transcorrentes sinistrais de direção NW-SE, o que facilitou ou até mesmo acelerou o processo de ruptura da rocha encaixante, favorecendo a percolação de fluidos hidrotermais ao longo de armadilhas estruturais, ou seja, fraturas de alívio que deram origem ao sistema de veios e vênulas.

A cassiterita de veio e a cassiterita de greisen do depósito de estanho Liberdade, quanto as suas composições químicas, diferem muito pouco e sugerem que este mineral-minério é, provavelmente, oriundo de uma mesma fonte hidrotermal. A principal diferença está no fato de a cassiterita de greisen ser um pouco mais puras do que a cassiterita de veio. O conteúdo de $\mathrm{FeO}_{\text {(total) }}$ é um pouco mais elevado nas cassiteritas de veios e pode ser atribuído às possíveis contaminações de $\mathrm{Fe}$ provenientes das rochas encaixantes da Suíte Intrusiva Alto Candeias.

Os dados aqui apresentados mostram que o aumento no conteúdo de Sn é acompanhado da diminuição nos conteúdos de $\mathrm{Fe}+\mathrm{Ti}+\mathrm{Nb}+\mathrm{W}$. Estas características mostram que os processos de substituição, tanto nas cassiteritas de veio como nas cassiteritas de greisen, podem ser representados através das seguintes equações: a) $\mathrm{Sn}^{4+}+\mathrm{O}^{2+} \leftrightarrow \mathrm{Ti}^{4+}+\mathrm{Fe}^{3+}+\mathrm{OH}^{-}$, onde esta equação expressa as substituições entre Fe, Ti e Sn; e b) $2 \mathrm{Nb}^{5+}+\mathrm{Fe}^{2+} \leftrightarrow 3(\mathrm{Sn}, \mathrm{Ti})^{4+} \mathrm{e} \mathrm{W}^{6+}+\mathrm{Fe}^{2+} \leftrightarrow 2(\mathrm{Sn}, \mathrm{Ti})^{4+}$, onde estas equações expressam as substituições acopladas de $\mathrm{Nb}$ e W durante as substituições entre $\mathrm{Fe}$, Ti e $\mathrm{Sn}$ (Neiva 1996, Murciego et al. 1997, Möller et al. 1998, Souza e Botelho 2009). 


\section{CAPÍTULO 4}

\section{GEOQUÍMICA ISOTÓPICA}

\subsection{APRESENTAÇÃO}

O estudo de isótopos radiogênicos e de isótopos estáveis é amplamente aplicado na solução de problemas de cunho geológico, seja como ferramenta para determinação da idade de rochas e minerais ou como parâmetro geoquímico no estudo petrogenético.

Considerando a extensão da granitogênese na Província Estanífera de Rondônia, pode-se dizer que existem poucos dados geocronológicos / isotópicos disponíveis. Contudo, principalmente na primeira década de 2000, houve grande aporte de dados geocronológicos / isotópicos principalmente por parte da CPRM - Serviço Geológico do Brasil, através de seus projetos de mapeamento geológico básico no Estado de Rondônia, além de dissertações de mestrado, teses de doutorado e artigos técnicos, desenvolvidos por pesquisadores de diversas universidades brasileiras.

Este capítulo apresenta dados de isótopos radiogênicos (U-Pb, Sm-Nd e Ar-Ar) e estáveis $\left(\delta^{18} \mathrm{O}\right.$ e $\left.\delta \mathrm{D}\right)$ nas fácies graníticas da Suíte Intrusiva Alto Candeias, bem como na mineralização de cassiterita associada, buscando avançar na compreensão da natureza, evolução magmática e metalogenética dessas rochas.

A Tabela 4.1 fornece informações a acerca dos dados geocronológicos disponíveis para a Suíte Intrusiva Alto Candeias.

\subsection{ISÓTOPOS U-Pb}

\subsubsection{Generalidades}

O elemento chumbo $(\mathrm{Pb})$ é formado pelos isótopos ${ }^{208} \mathrm{~Pb},{ }^{207} \mathrm{~Pb},{ }^{206} \mathrm{~Pb}$ e ${ }^{204} \mathrm{~Pb}$, sendo o último o único a ter sua abundância terrestre mantida constante desde a origem da Terra (Tosdal et al. 1999). Os demais resultam de reações de decaimento radioativo, o primeiro do tório $\left({ }^{232} \mathrm{Th} \rightarrow{ }^{208} \mathrm{~Pb}\right)$ e os outros dois do urânio $\left({ }^{235} \mathrm{U} \rightarrow{ }^{207} \mathrm{~Pb}\right.$ e $\left.{ }^{238} \mathrm{U} \rightarrow{ }^{206} \mathrm{~Pb}\right)$ e, dessa forma, suas abundâncias têm aumentado continuamente com o passar do tempo.

Alguns modelos de datação U-Pb foram propostos, porém os mais conhecidos e utilizados são os denominados de "estágio único" (Holmes 1946, in Faure 1986; Houthermans 1946, in Faure 1986) e de "estágio duplo" (Stacey e Kramers 1975).

No modelo de estágio único, a Terra é considerada no início de sua formação como uma massa fluida na qual $\mathrm{U}$, Th e $\mathrm{Pb}$ estavam distribuídos uniformemente e a composição isotópica de $\mathrm{Pb}$ era a mesma em qualquer lugar. A diferenciação em manto, crosta inferior e crosta superior só causou pequenas diferenças regionais nas razões ${ }^{238} \mathrm{U} /{ }^{204} \mathrm{~Pb}$ e ${ }^{232} \mathrm{Th} /{ }^{204} \mathrm{~Pb}$. Em cada ambiente, a razão U/Pb mudou somente em decorrência do decaimento radioativo do $\mathrm{U}$ para $\mathrm{Pb}$ e, ao longo do tempo geológico, o Pb se separou do U e Th para formar minerais, mantendo, desde então, sua composição isotópica constante.

O modelo de estágio duplo representa um refinamento na modelagem da evolução do $\mathrm{Pb}$, já que o modelo anterior não traduz a evolução real de muitos sistemas geológicos. De acordo com o modelo em estágio duplo, a evolução do $\mathrm{Pb}$ foi iniciada há 4,57 Ga (primeiro estágio), adotando as médias das razões ${ }^{238} \mathrm{U} /{ }^{204} \mathrm{~Pb}$ e ${ }^{232} \mathrm{Th} /{ }^{204} \mathrm{~Pb}$ iguais a $7,19 \mathrm{e} 32,11$, respectivamente. 
Tabela 4.1. Dados isotópicos para os granitos da Suíte Intrusiva Alto Candeias.

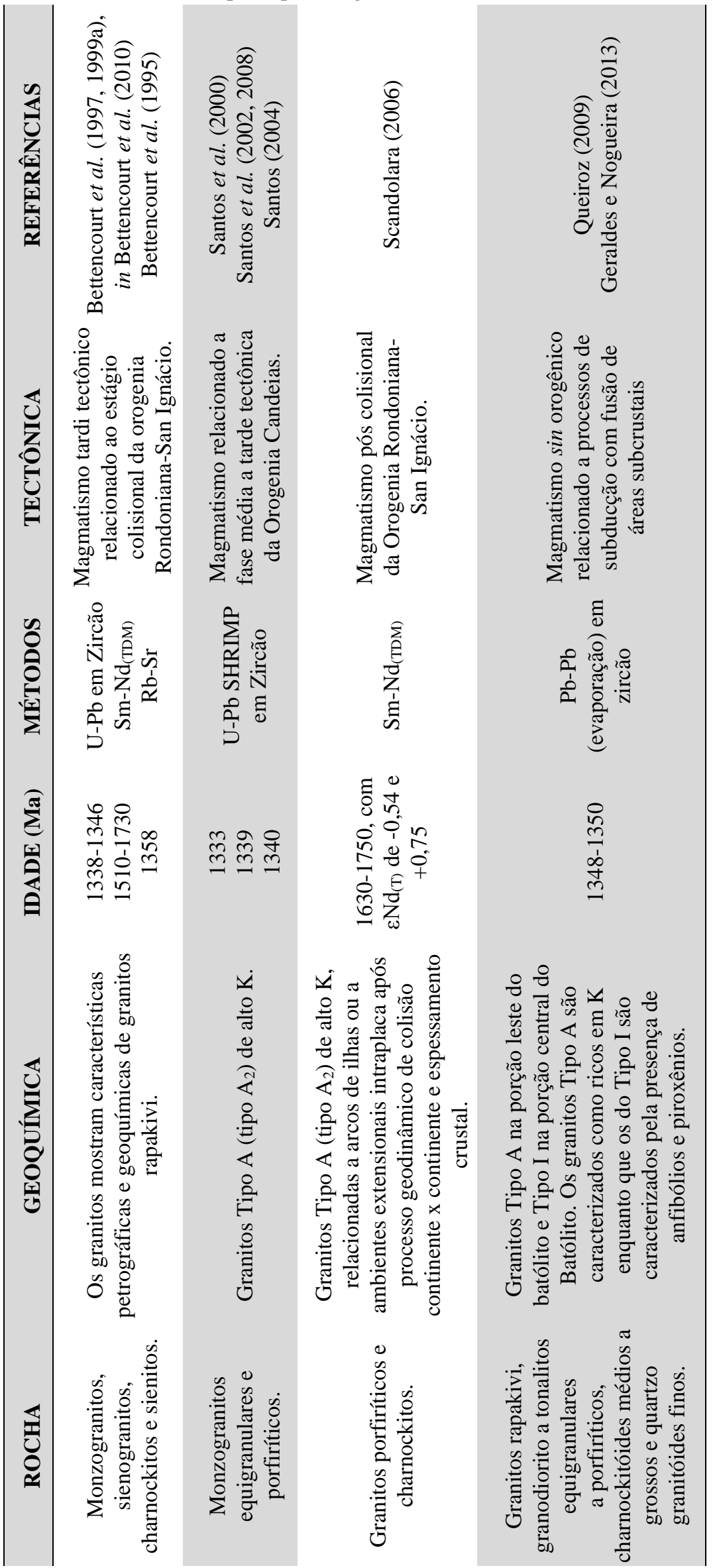


No início do segundo estágio, há 3,70 Ga, as razões químicas primordiais foram modificadas nos reservatórios globais, por conta da diferenciação geoquímica da Terra, e foram mantidas constantes, desde o momento em que o $\mathrm{Pb}$ foi incorporado nos minerais. $\mathrm{E}$ as razões de ${ }^{238} \mathrm{U} /{ }^{204} \mathrm{~Pb}$ e ${ }^{232} \mathrm{Th} /{ }^{204} \mathrm{~Pb}$ passaram a ser 9,74 e 37,19 , respectivamente.

A razão ${ }^{238} \mathrm{U} /{ }^{204} \mathrm{~Pb}$ é conhecida como $\mu \mathrm{e}$, com base nela, é possível inferir a fonte dos magmas, uma vez que este parâmetro apresenta valores relativamente definidos para as diferentes camadas da litosfera. Valores de $\mu$ entre 7,5 e 8,2 indicam evolução a partir de fontes mantélicas, entre 8,2 e 12, evolução na crosta superior e valores menores que 7,5, evolução na crosta inferior (Oversby 1976).

Zartman e Doe (1981) propuseram diferentes curvas de evolução isotópica para o $\mathrm{Pb}$, dependendo do reservatório geoquímico de residência (crosta superior, crosta inferior, manto e um reservatório de mistura - orogênico).

O zircão é uma fase mineral acessória tradicionalmente usada na datação U-Pb de granitos, principalmente devido a sua estabilidade química frente a processos geológicos em estágio subsolidus e ao intemperismo (Faure 1986, Dickin 2005).

Idades U-Pb em zircão para rochas graníticas da Suíte Intrusiva Alto Candeias foram apresentadas por Bettencourt et al. (1997 e 1999a), os quais posicionam as mesmas em um intervalo entre 1346 a 1338 Ma, enquanto que Santos (2004) e Santos et al. (2000, 2002, 2008) apresentaram idade variando entre 1333 e 1340 Ma, usando a metodologia U-Pb SHRIMP em zircão. Os dados aqui apresentados fornecem informações acerca da idade das três fácies graníticas mapeadas da Suíte Intrusiva Alto Candeias no depósito de estanho Liberdade.

\subsubsection{Resultados}

Os cristais de zircão das diferentes fácies de rochas estudadas exibem formas subédricas a euédricas com terminações bipiramidais, cor entre vermelho claro, cor-de-rosa e incolores, translúcidos, com tamanho entre 300 e $700 \mu \mathrm{m}$, internamente zonados, pouco fraturados e com inclusões minerais.

A amostra CNRO-008 representa a Fácies 1 da Suíte Intrusiva Alto Candeias. A Tabela 4.2 apresenta o quadro resumo dos dados LA-ICP-MS obtidos na amostra, onde foram analisados 25 cristais de zircão e, a partir de uma população de 21 cristais, foi possível calcular a idade de 1356,9 $\pm 3,7 \mathrm{Ma}(\mathrm{MSWD}=0.96)$, cujo diagrama concórdia é visualizado na Figura 4.1A.

A amostra CNRO-007 representa a Fácies 2 da Suíte Intrusiva Alto Candeias. A Tabela 4.2 apresenta o quadro resumo dos dados LA-ICP-MS obtidos na amostra, onde foram analisados 22 cristais de zircão e, a partir de uma população de 15 cristais, foi possível calcular a idade de 1343,8 $\pm 4,5 \mathrm{Ma}$ (MSWD=1.05), cujo diagrama concórdia é visualizado na Figura 4.1B. Outras 02 amostras da Fácies 2 foram analisadas, porém ambas mostraram-se inadequadas para a definição da idade de cristalização do fácies em virtude do alto grau de discordância das análises, o que pode ser atribuído a distúrbios do sistema U-Th-Pb causados pela interação rocha-fluido em estágio tarde à pós-magmático ou pela frequência de zircões herdados.

A amostra CNRO-001D representa a Fácies 3 da Suíte Intrusiva Alto Candeias. A Tabela 4.2 apresenta o quadro resumo dos dados LA-ICP-MS obtidos na amostra, onde foi analisado 40 cristais de zircão e, a partir de uma população de 14 cristais, foi possível calcular a idade de 1336,0 $\pm 24 \mathrm{Ma}$ $(\mathrm{MSWD}=3.9)$ e cujo diagrama concórdia é visualizado na Figura 4.1C. 
Tabela 4.2. Sumário dos dados LA-ICP-MS obtidos nas amostras CNRO-008 (Fácies 1), CNRO-007 (Fácies 2) e CNRO-001D (Fácies 3).

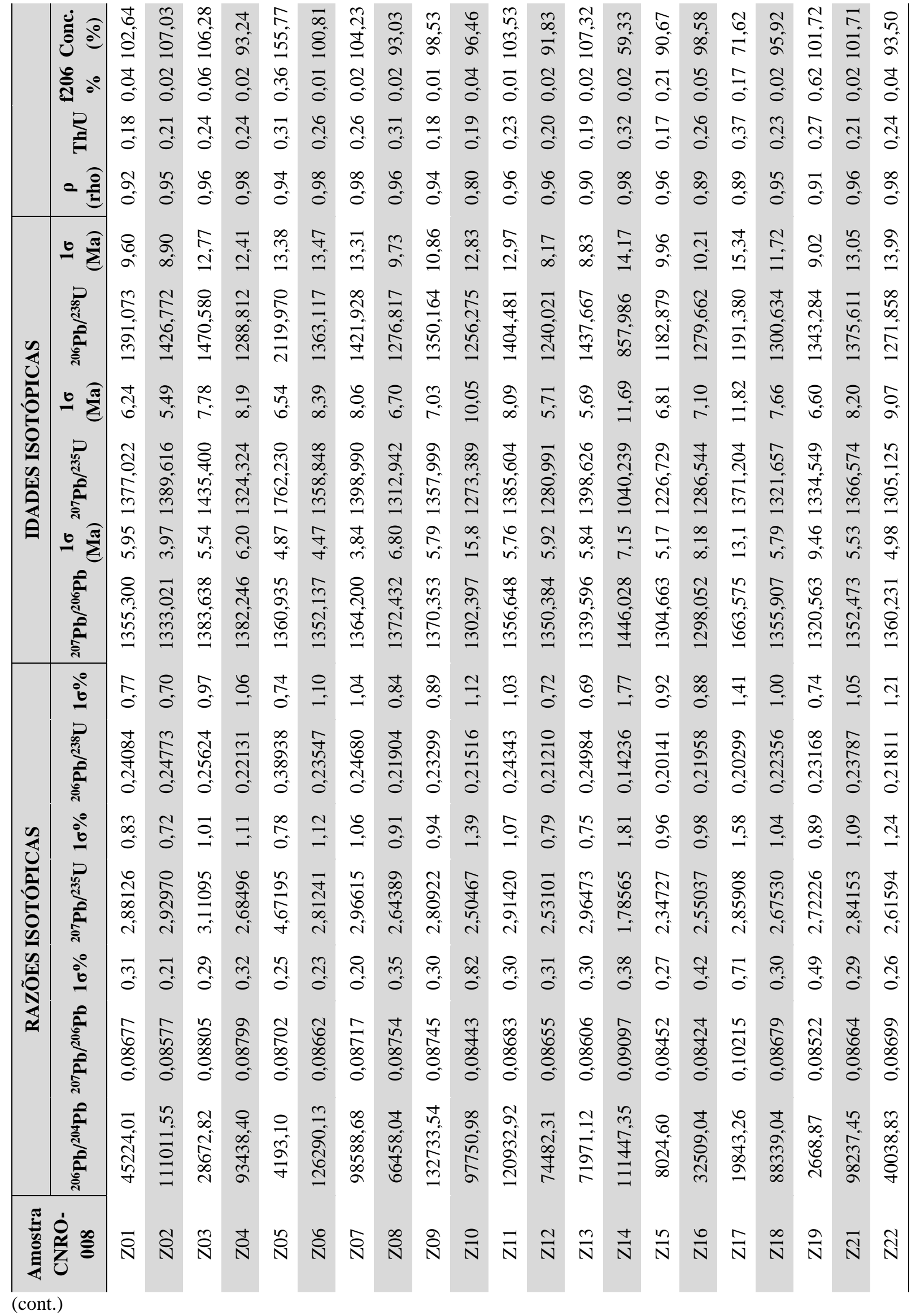


(cont.)

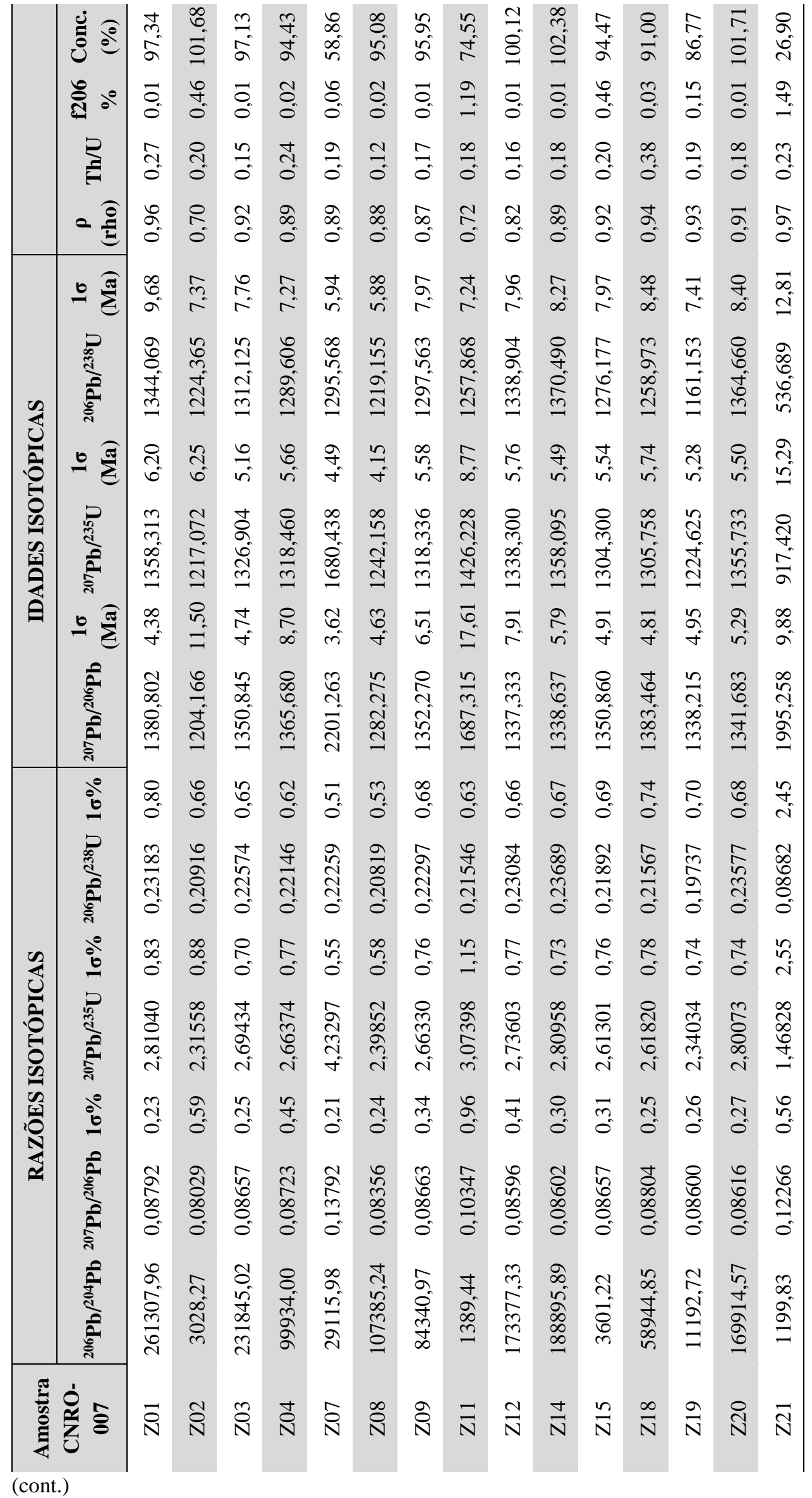


(cont.)

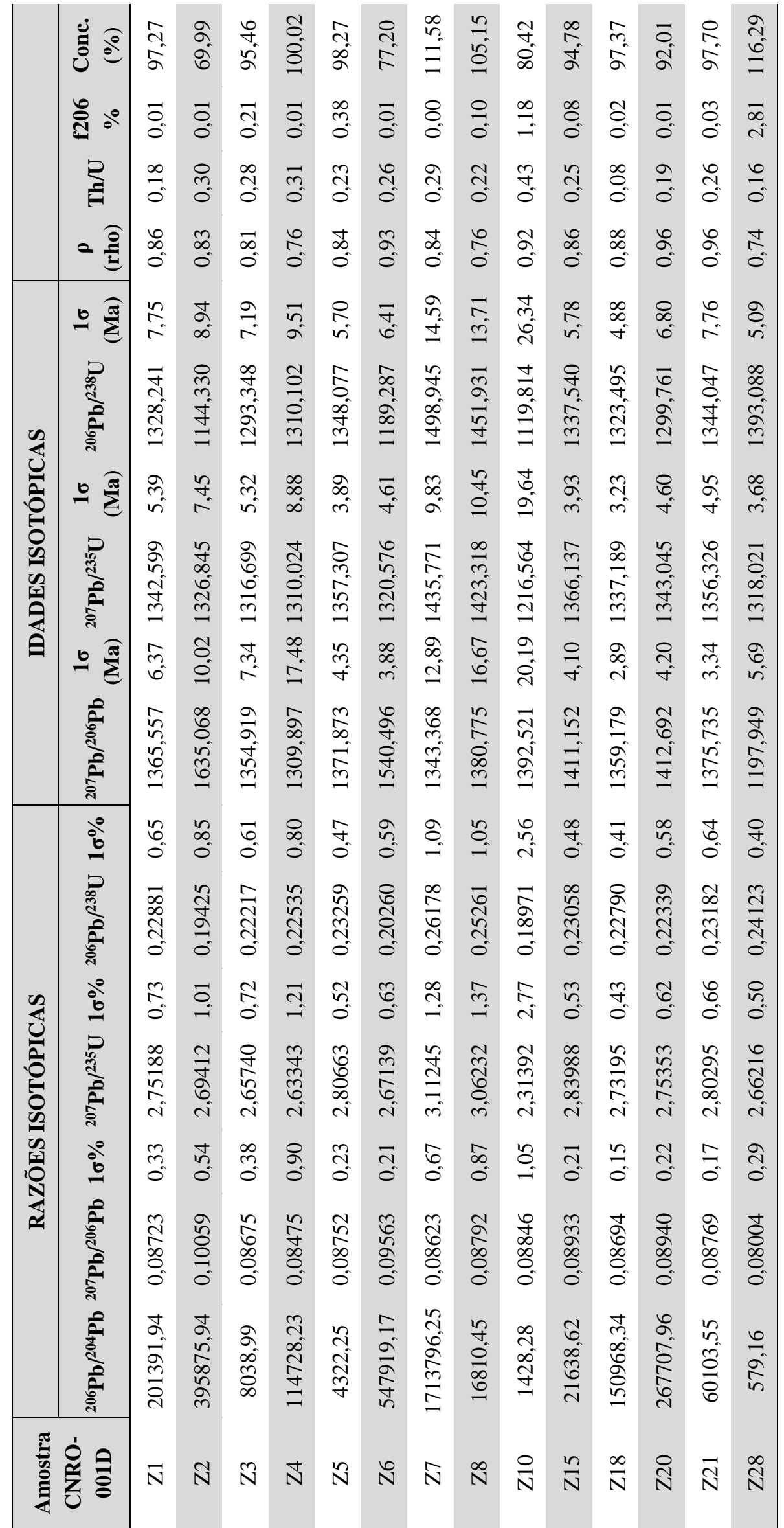




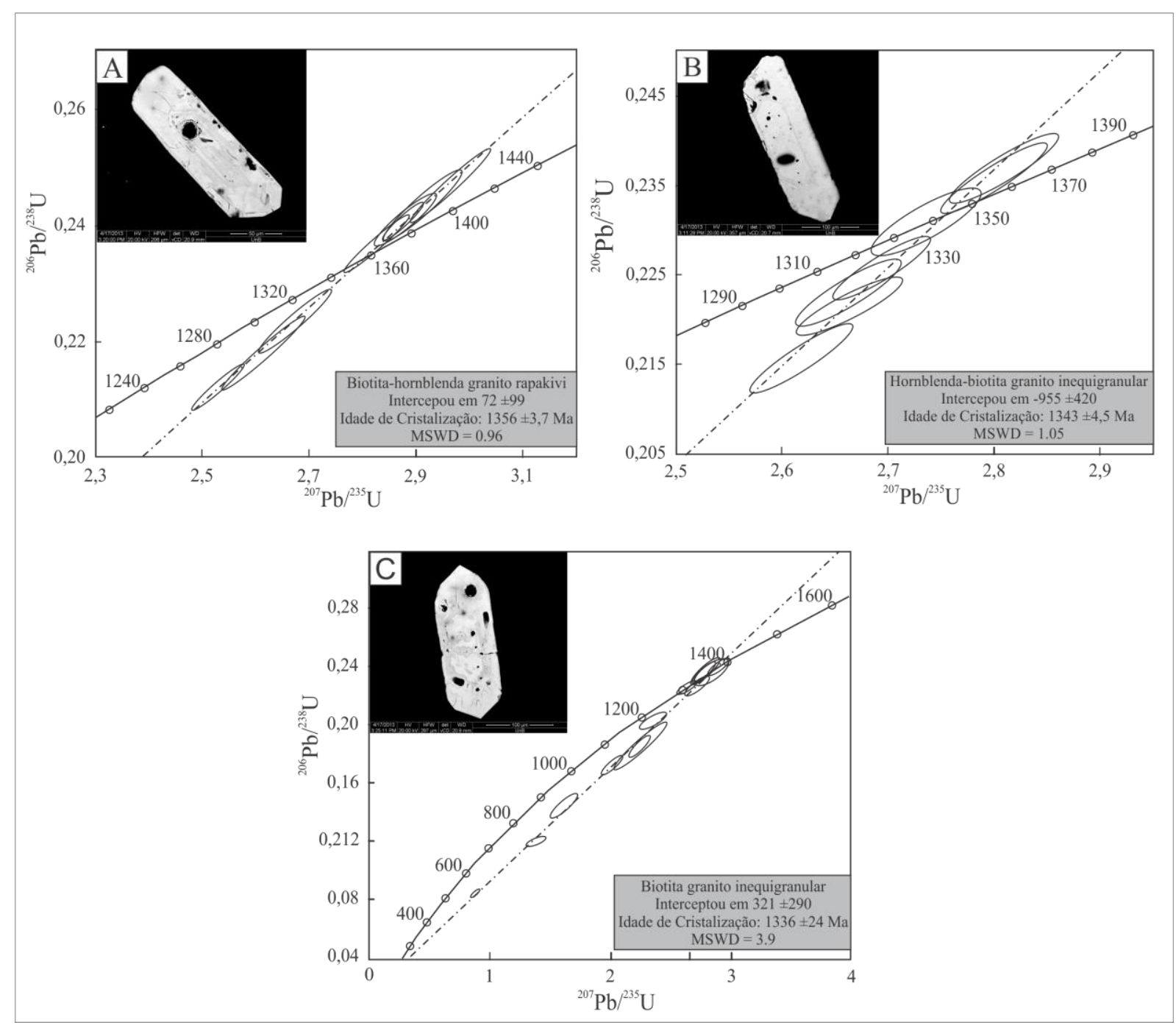

Figura 4.1. Diagrama Concórdia para análises LA-ICP-MS obtidas em grãos de zircão das amostras CNRO-008 (A), CNRO-007 (B) e CNRO-001D (C), representando a idade das rochas graníticas da Suíte Intrusiva Alto Candeias no depósito de estanho Liberdade.

O alto valor da margem de erro da amostra CNRO-001D ocorre em virtude do alto grau de discordância das análises, o que pode ser atribuído a distúrbios do sistema U-Th- $\mathrm{Pb}$ causados, também, pela interação rocha-fluido em estágio tarde à pós-magmático ou pela frequência de zircões herdados. Nas análises dos zircões dessa amostra, ficou constatada uma grande quantidade de $\mathrm{Pb}$ comum, influenciando, também, diretamente no valor da margem de erro.

\subsection{ISÓTOPOS DE Sm-Nd}

\subsubsection{Generalidades}

Samário $(\mathrm{Sm})$ e neodímio $(\mathrm{Nd})$ são elementos terras raras leves, possuem três isótopos cada um, com massas atômicas de 144, 147, 148, 149, 150, 152 e 154, e de 142, 143, 144, 145, 146, 148 e 150 , respectivamente, porém, o isótopo ${ }^{143} \mathrm{Nd}$ resulta da desintegração nuclear do isótopo ${ }^{147} \mathrm{Sm}$. Suas concentrações em rochas ígneas crescem à medida que aumenta o grau de diferenciação das mesmas, pois, na maior parte dos casos, são considerados elementos incompatíveis. No entanto a razão $\mathrm{Sm} / \mathrm{Nd}$ 
decresce, já que o $\mathrm{Nd}$ se concentra mais no fluido magmático quando comparado ao Sm durante o processo da cristalização fracionada.

Segundo Faure (1986), os minerais exercem um considerável grau de seletividade na admissão de ETR a qual reflete na concentração dos ETR nas rochas. Por exemplo, piroxênio, anfibólio e granada costumam concentrar ETR pesados, enquanto que feldspatos, biotita e apatita concentram os ETR leves.

A boa distribuição de $\mathrm{Sm}$ e $\mathrm{Nd}$ nas mais variadas litologias, a baixa mobilidade destas terras raras durante os processos intempéricos, hidrotermais e metamórficos, bem como o comportamento geoquímico similar de Sm e Nd, permite que o método Sm-Nd tenha uma aplicação muito ampla no estudo de idades e evolução da crosta.

A premissa fundamental do método Sm-Nd é que a crosta continental se formou por processos de fracionamento químico a partir do manto, sendo que durante o tempo em que o primeiro segmento de crosta se forma, ele tem valores de $\varepsilon \mathrm{Nd}$ idênticos aos do manto, divergindo subsequentemente.

O comportamento sistemático do $\mathrm{Sm}$ e Nd em sistemas ígneos e a posição bem definida de curvas de crescimento para manto empobrecido e condrito tem levado ao uso das idades modelo Sm$\mathrm{Nd}_{(\mathrm{TDM})}$. Entretanto, não se deve superestimar a idade modelo devido aos erros e incertezas maiores do que as idades de isócronas. A complicação acerca das interpretações de idades modelo provém do fato de que ocorre incorporação de novos materiais do manto na crosta continental antiga, produzindo rochas mistas entre material juvenil e crosta antiga. Com isso, a análise de rocha total das rochas graníticas tem como principal objetivo a determinação da idade modelo e da origem do magma que os geraram.

O parâmetro $\varepsilon \mathrm{Nd}$ compara as razões ${ }^{143} \mathrm{Nd} /{ }^{144} \mathrm{Nd}$ atual ou da época da sua formação com as do CHUR. Se, à época da cristalização da rocha, o magma parental tiver razão ${ }^{143} \mathrm{Nd} /{ }^{144} \mathrm{Nd}$ mais elevada que o condrito, o $\varepsilon \mathrm{Nd}$ será positivo e a fonte seria o manto superior. Caso o magma parental tiver razão ${ }^{143} \mathrm{Nd} /{ }^{144} \mathrm{Nd}$ menor que a do condrito, o $\varepsilon \mathrm{Nd}$ será negativo e a fonte seria crustal.

\subsubsection{Resultados}

Foram realizadas 8 análises, distribuídas em 4 amostras de granitos da Fácies 1 (biotitahornblenda granito rapakivi), 3 amostras do granito da Fácies 2 (hornblenda-biotita granito inequigranular médio) e 1 amostra do granito da Fácies 3 (biotita granito inequigranular fino), as quais mostram que as três fácies se originaram a partir de fontes comuns e cujos dados estão na Tabela 4.3.

Tabela 4.3. Composição isotópica Sm-Nd das rochas graníticas pertencentes a Suíte Intrusiva Alto Candeias.

\begin{tabular}{|c|c|c|c|c|c|c|c|c|}
\hline Amostras & $\begin{array}{c}\text { Sm } \\
(\mathbf{p p m})\end{array}$ & $\begin{array}{c}\text { Nd } \\
(\mathbf{p p m})\end{array}$ & ${ }^{147} \mathrm{Sm} /{ }^{144} \mathrm{Nd}$ & $\begin{array}{c}{ }^{143} \mathrm{Nd} /{ }^{144} \mathrm{Nd} \\
( \pm 2 \mathrm{SE})\end{array}$ & $\mathbf{e N d}_{(0)}$ & $\mathbf{f}_{\mathrm{Sm} / \mathrm{Nd}}$ & $\mathbf{e N d}_{(T)}$ & $\begin{array}{l}\text { TDM } \\
\text { (Ga) }\end{array}$ \\
\hline CNRO-001A & 21,231 & 107,388 & 0,1195 & $0,511955 \pm 16$ & $-13,32$ & $-0,39$ & 0,03 & 1,76 \\
\hline CNRO-001B & 2,630 & 15,345 & 0,1036 & $0,511893 \pm 15$ & $-14,53$ & $-0,47$ & 1,57 & 1,59 \\
\hline CNRO-001B II & 18,214 & 92,859 & 0,1186 & $0,511990 \pm 06$ & $-12,64$ & $-0,40$ & 0,88 & 1,69 \\
\hline CNRO-008 & 17,882 & 91,042 & 0,1187 & $0,511934 \pm 12$ & $-13,73$ & $-0,40$ & $-0,25$ & 1,78 \\
\hline CNRO-004 & 32,472 & 182,289 & 0,1077 & $0,511862 \pm 10$ & $-15,14$ & $-0,45$ & 0,11 & 1,70 \\
\hline CNRO-006 & 26,588 & 157,685 & 0,1019 & $0,511761 \pm 17$ & $-17,11$ & $-0,48$ & $-0,87$ & 1,75 \\
\hline CNRO-007 & 27,613 & 151,988 & 0,1098 & $0,511887 \pm 13$ & $-14,65$ & $-0,44$ & 0,24 & 1,70 \\
\hline CNRO-001D & 20,088 & 120,487 & 0,1008 & $0,511752 \pm 11$ & $-17,28$ & $-0,49$ & $-0,94$ & 1,74 \\
\hline
\end{tabular}

As três fácies graníticas da Suíte Intrusiva Alto Candeias no depósito de estanho Liberdade, apresentaram valores similares em relação aos dados de Sm-Nd (Tabela 4.3). A idade modelo mais alta e a mais baixa pertencem ao biotita-hornblenda granito rapakivi $(1,78$ e 1,59 Ga, respectivamente). As idades-modelo (TDM) e o $\varepsilon N d$ das 8 amostras foram calculadas com base no 
modelo do manto empobrecido, segundo os parâmetros estabelecidos por DePaolo (1981). Para os cálculos de $\varepsilon \mathrm{Nd}_{(\mathrm{t})}$, foi utilizada a idade de 1356,9 Ma para a Fácies 1, 1343,8 Ma para a Fácies 2 e 1336,0 Ma para a Fácies 3. Em geral, apresentam $\varepsilon \mathrm{Nd}_{(\mathrm{t})}$ positivo (exceção das amostras CNRO-008 na Fácies 1, CNRO-006 na Fácies 2 e CNRO-001D na Fácies 3, que apresentaram valores levemente negativos) e variáveis conteúdos de $\mathrm{Sm}$ e $\mathrm{Nd}$, cuja razão ${ }^{147} \mathrm{Sm} /{ }^{144} \mathrm{Nd}$ varia de 0,1036 a 0,1195 na Fácies 1, 0,1019 a 0,1098 na Fácies 2 e 0,1008 na Fácies 3.

$\mathrm{O}$ diagrama $\varepsilon \mathrm{Nd} v s \mathrm{~T}$ resume a evolução dos padrões de $\mathrm{Nd}$ para as rochas investigadas (Figura 4.2), indicando a existência de um único grupo de rochas e que as rochas das três fácies foram originadas a partir de fontes comuns.

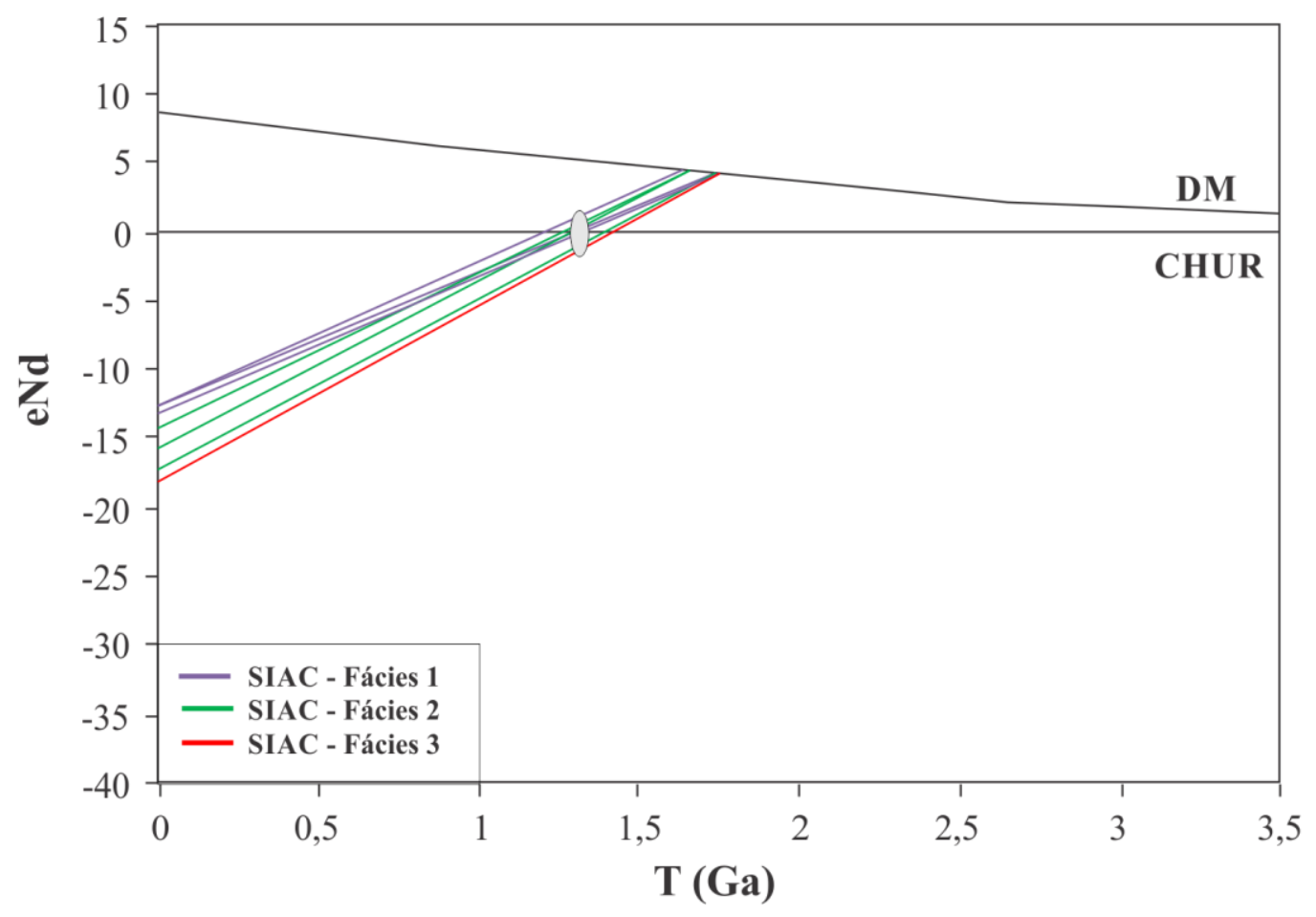

Figura 4.2. Evolução isotópica Sm-Nd (idades e $\varepsilon N d$ ) para os fácies graníticos da Suíte Intrusiva Alto Candeias encontrados no depósito de estanho Liberdade.

\subsection{ISÓTOPOS DE Ar-Ar}

\subsubsection{Generalidades}

O elemento argônio (Ar) é formado pelos isótopos ${ }^{40} \mathrm{Ar},{ }^{39} \mathrm{Ar},{ }^{38} \mathrm{Ar},{ }^{37} \mathrm{Ar}$ e ${ }^{36} \mathrm{Ar}$, onde o isótopo ${ }^{40} \mathrm{Ar}$ é o mais abundante na Terra $(99,6 \%)$. O método ${ }^{40} \mathrm{Ar} /{ }^{39} \mathrm{Ar}$ é baseado na produção de ${ }^{39} \mathrm{Ar}$ por bombardeamento de raios nêutrons rápidos a partir do ${ }^{40} \mathrm{Ar}$. $\mathrm{O}{ }^{39} \mathrm{Ar}$ formado tem uma meia-vida de 269 anos. A idade das amostras é medida em relação a um padrão de referência de idade conhecida. A principal vantagem do método Ar-Ar é que o Ar pode ser perdido parcialmente por etapas de aquecimento das amostras irradiadas (Faure 1986, Dickin 2005).

Rochas e minerais que têm experimentado perda parcial de Ar depois da cristalização podem produzir espectros de idade tendo um platô formado pela perda de Ar de lugares retentivos a elevadas temperaturas. Tais dados do platô podem ser iguais ou sensivelmente menores que o tempo de cristalização. Rochas ou minerais contendo excesso de ${ }^{40} \mathrm{Ar}$ usualmente produzem idades anomalamente velhas em baixas temperaturas, mas podem não atingir platôs reais em temperaturas mais elevadas. No entanto, o método Ar-Ar não detecta a presença de excesso de ${ }^{40} \mathrm{Ar}$ em todos os 
casos. Quando o excesso de ${ }^{40} \mathrm{Ar}$ está uniformemente distribuído através dos grãos do mineral, um platô pode ser observado no espectro dos dados, mas o resultado assim obtido excede a idade do mineral (Roddick 1983, Faure 1986, McDougall e Harrison 1988, Dickin 2005)

Diagramas de correlação com as razões ${ }^{40} \mathrm{Ar} /{ }^{36} \mathrm{Ar}$ e ${ }^{39} \mathrm{Ar} /{ }^{36} \mathrm{Ar}$ medidas das frações de gás perdidas das amostras não perturbadas formam isócronas. A interseção da isócrona com o eixo ${ }^{39} \mathrm{Ar} /{ }^{36} \mathrm{Ar}$ dá a composição isotópica do Ar aprisionado no momento da formação do mineral. A idade é calculada pela inclinação obtida da reta isocrônica, correspondendo à razão ${ }^{40} \mathrm{Ar} * / 39 \mathrm{Ar}$. No cálculo do erro das idades são considerados os erros analíticos sobre o gradiente, o fluxo e a incerteza da idade do padrão. As idades totais integradas Ar/Ar correspondem às idades K/Ar convencionais.

A versatilidade do método Ar-Ar tem sido intensificada pelo uso de lasers para extrair Ar de grãos individuais de mineral e para demonstrações de que rochas metamórficas de baixo grau podem ser datadas em circunstâncias favoráveis. Em adição, os dados coletados rotineiramente por degaseificação em etapas do mineral permitem inferir coeficientes aparentes de difusão e energias de ativação a partir das quais a temperatura de fechamento pode ser calculada em função da idade do "platô". Esta extensão do método permite construir curvas de resfriamento para rochas que tem diferentes minerais portadores de K com diferentes temperaturas de fechamento (Harrison 1981, Roddick 1983, Faure 1986, McDougall e Harrison 1988, Cheilletz et al. 1992, Dickin 2005).

\subsubsection{Resultados}

O emprego do método ${ }^{40} \mathrm{Ar}-{ }^{39} \mathrm{Ar}$ têm se tornado uma excelente ferramenta para desvendar as histórias dos processos hidrotermais tardi a pós-magmáticos em todo o mundo. Como os granitos rapakivi da Província Estanífera de Rondônia (PER) estão inseridos no contexto do Cráton Amazônico, esse método se torna uma importante ferramenta para se determinar a idade de resfriamento do sistema hidrotermal e sua relação temporal com o evento magmático.

Para a obtenção da idade, pelo método ${ }^{40} \mathrm{Ar}-{ }^{39} \mathrm{Ar}$, do processo hidrotermal tardi a pósmagmático do depósito de estanho Liberdade, utilizaram-se micas (muscovita) da amostra CNRO003, presentes no quartzo-muscovita greisen com fluorita, onde o minério de cassiterita ocorre nas formas maciça e disseminada. A Tabela 4.4 sintetiza os dados analíticos ${ }^{40} \mathrm{Ar}-{ }^{39} \mathrm{Ar}$ para a amostra CNRO-003.

$\mathrm{O}$ resultado analítico obtido apresentou um espectro de idades ${ }^{40} \mathrm{Ar}-{ }^{39} \mathrm{Ar}$ marcado por uma idade platô de 1308,24 $\pm 4,60 \mathrm{Ma}$, com MSWD = 0.172 e erro analítico na ordem de 9,42\% para 99,9\% do ${ }^{39} \mathrm{Ar}$ liberado (Figura 4.3A). A relação nas razões $\mathrm{Ca} / \mathrm{K}$ e $\mathrm{Cl} / \mathrm{K}\left({ }^{39} \mathrm{Ar}\right)$ revelam uma composição bastante homogênea, sem significativa contribuição de argônio nos produtos alterados e/ou modificados por distúrbios termais posteriores (Figura 4.3B), sugerindo que a idade de fechamento obtida está relacionada ao fechamento do processo hidrotermal tarde a pós-magmático responsável pela formação da cassiterita.

Os dados Ar-Ar disponíveis para depósitos de estanho na porção centro-norte da Província Estanífera de Rondônia, revelam um intervalo de idades variando de 959 a 1053 Ma (Priem et al. 1971, Leite Jr. et al. 2001, Bettencourt et al. 2005a, Souza et al. 2005, Souza et al. 2010), sendo interpretados como processo hidrotermal tardi a pós-magmático, principalmente associados a Suíte Intrusiva Rondônia (Tabela 4.5). Estes dados são relativamente consistentes com outros métodos de investigação geocronológica também aplicados aos mesmos depósitos, tais como $\mathrm{K}-\mathrm{Ar}$ e U-Pb, que indicou idades variando de 1006 a $961 \mathrm{Ma}$, porém, com algum grau de incerteza (Leite Jr. et al. 2001, Souza et al. 2005). Por outro lado, na porção centro-sul e em parte do sudeste do Estado de Rondônia, foram obtidos dados Ar-Ar em hornblenda e biotita a partir de rochas do embasamento, os quais apresentaram idades variando de 1335 a $1313 \mathrm{Ma}$ e 1209 a $1062 \mathrm{Ma}$, interpretadas como registros de dois eventos tectono-metamórficos regionais relacionados ao orógeno Rondoniano-San Ignácio e 
Sunsás (Sadowski e Bettencourt 1996, Rizzotto et al. 2002, Tohver et al. 2002, Tohver et al. 2005, Scandolara 2006).

Tabela 4.4. Dados analíticos ${ }^{40} \mathrm{Ar}-{ }^{39} \mathrm{Ar}$ da amostra CNRO-003 sumarizados.

\begin{tabular}{|c|c|c|c|c|c|c|c|c|}
\hline Power & ${ }^{36} \mathrm{Ar} /{ }^{40} \mathrm{Ar}$ & ${ }^{39} \mathrm{Ar} /{ }^{40} \mathrm{Ar}$ & $\mathbf{r}$ & $\mathrm{Ca} / \mathrm{K}$ & $\begin{array}{c}\% \\
{ }^{40} \mathrm{Atm} \\
\end{array}$ & $\begin{array}{c}\% \% \\
{ }^{\% 9} \mathrm{Ar} \\
\end{array}$ & ${ }^{40} \mathrm{Ar}{ }^{*} /{ }^{39} \mathrm{~K}$ & Age (Ma) \\
\hline 1,8 & $\begin{array}{c}0,000818 \\
\pm 0,000484\end{array}$ & $\begin{array}{r}0,013450 \\
\pm 0,000915\end{array}$ & 0,001 & 0,817 & 24,14 & 0,11 & $56,39 \pm 11,51$ & $1206,4 \pm 179,6$ \\
\hline$<2,00$ & $\begin{array}{r}0,000247 \\
\pm 0,000197\end{array}$ & $\begin{array}{r}0,014690 \\
\pm 0,000730\end{array}$ & 0,000 & 0,474 & 7,28 & 0,24 & $63,12 \pm 5,18$ & $1308,3 \pm 76,4$ \\
\hline$<2,30$ & $\begin{array}{r}0,000077 \\
\pm 0,000027\end{array}$ & $\begin{array}{r}0,015369 \\
\pm 0,000232\end{array}$ & 0,000 & 0,009 & 2,27 & 1,85 & $63,59 \pm 1,10$ & $1315,3 \pm 16,1$ \\
\hline$<2,40$ & $\begin{array}{r}0,000059 \\
\pm 0,000028\end{array}$ & $\begin{array}{c}0,015577 \\
\pm 0,000192\end{array}$ & 0,000 & 0,035 & 1,74 & 3,03 & $63,08 \pm 0,94$ & $1307,8 \pm 13,9$ \\
\hline$<2,50$ & $\begin{array}{r}0,000026 \\
\pm 0,000019\end{array}$ & $\begin{array}{c}0,015702 \\
\pm 0,000211\end{array}$ & 0,000 & 0,045 & 0,75 & 5,03 & $63,20 \pm 0,93$ & $1309,6 \pm 13,6$ \\
\hline$<2,60$ & $\begin{array}{r}0,000018 \\
\pm 0,000015\end{array}$ & $\begin{array}{c}0,015807 \\
\pm 0,000223\end{array}$ & 0,000 & 0,009 & 0,52 & 9,25 & $62,93 \pm 0,93$ & $1305,6 \pm 13,8$ \\
\hline$<2,70$ & $\begin{array}{r}0,000010 \\
\pm 0,000008\end{array}$ & $\begin{array}{r}0,015800 \\
\pm 0,000214\end{array}$ & 0,000 & 0,004 & 0,31 & 11,61 & $63,10 \pm 0,87$ & $1308,1 \pm 12,8$ \\
\hline$<2,80$ & $\begin{array}{r}0,000012 \\
\pm 0,000016\end{array}$ & $\begin{array}{r}0,015765 \\
\pm 0,000190\end{array}$ & 0,000 & 0,011 & 0,34 & 9,17 & $63,22 \pm 0,82$ & $1309,8 \pm 12,1$ \\
\hline$<2,90$ & $\begin{array}{r}0,000013 \\
\pm 0,000021\end{array}$ & $\begin{array}{c}0,015744 \\
\pm 0,000186\end{array}$ & 0,000 & 0,043 & 0,38 & 9,55 & $63,27 \pm 0,85$ & $1310,6 \pm 12,5$ \\
\hline$<3,00$ & $\begin{array}{c}0,000004 \\
\pm 0,000016\end{array}$ & $\begin{array}{r}0,015768 \\
\pm 0,000206\end{array}$ & 0,000 & 0,031 & 0,12 & 12,85 & $63,34 \pm 0,88$ & $1311,6 \pm 13,0$ \\
\hline$<3,20$ & $\begin{array}{r}0,000004 \\
\pm 0,000019\end{array}$ & $\begin{array}{r}0,015845 \\
\pm 0,000172\end{array}$ & 0,000 & 0,039 & 0,12 & 18,55 & $63,03 \pm 0,78$ & $1307,1 \pm 11,5$ \\
\hline$<3,40$ & $\begin{array}{r}0,000009 \\
\pm 0,000016\end{array}$ & $\begin{array}{c}0,015871 \\
\pm 0,000194\end{array}$ & 0,000 & 0,023 & 0,26 & 11,54 & $62,84 \pm 0,82$ & $1304,3 \pm 12,2$ \\
\hline$<3,70$ & $\begin{array}{c}0,000013 \\
\pm 0,000020\end{array}$ & $\begin{array}{c}0,015802 \\
\pm 0,000199\end{array}$ & 0,000 & 0,064 & 0,38 & 7,23 & $63,04 \pm 0,88$ & $1307,2 \pm 13,0$ \\
\hline
\end{tabular}
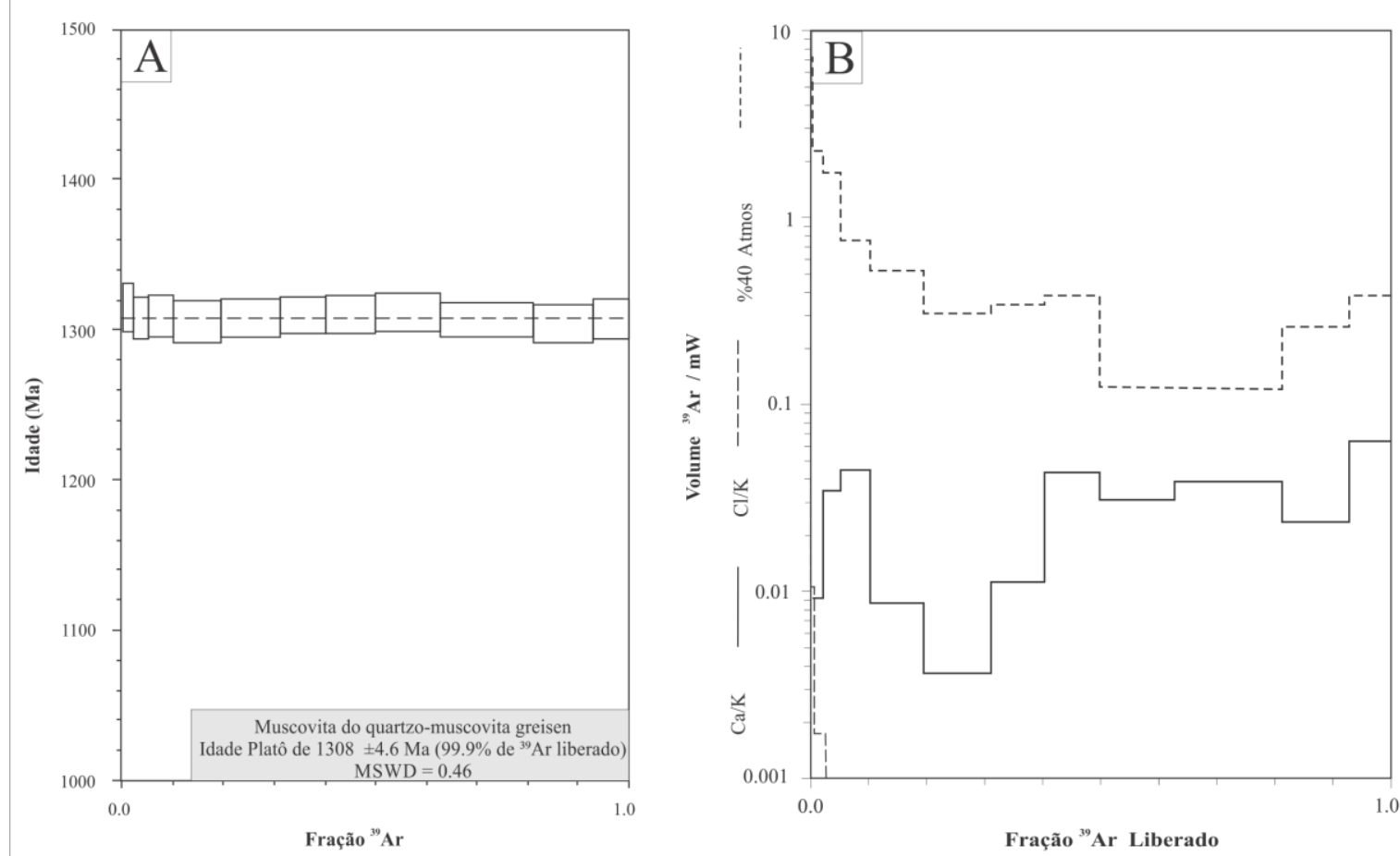

Figura 4.3. Gráficos: A) Idades platô ${ }^{40} \mathrm{Ar} /{ }^{39} \mathrm{Ar}$; B) relações $\mathrm{Ca} / \mathrm{K}$ e $\mathrm{Cl} / \mathrm{K}$ da muscovita da amostra CNRO-003 aplicadas ao cálculo da Idade Ar-Ar. 
Tabela 4.5. Dados analíticos disponíveis para depósitos de estanho relacionados a Província Estanífera de Rondônia.

\begin{tabular}{|c|c|c|c|c|c|c|}
\hline $\begin{array}{l}\text { DEPÓSITO } \\
\text { ESTANÍFERO }\end{array}$ & $\begin{array}{l}\text { UNIDADE } \\
\text { REGIONAL }\end{array}$ & MÉTODO & MINERAL & FÁCIES & $\begin{array}{l}\text { IDADES } \\
\text { (MA) }\end{array}$ & REFERÊNCIAS \\
\hline \multirow[t]{2}{*}{ Santa Bárbara } & \multirow{6}{*}{$\begin{array}{l}\text { Suíte Intrusiva } \\
\text { Rondônia } \\
\text { (995-956 Ma) }\end{array}$} & $\mathrm{Ar}-\mathrm{Ar}$ & $\begin{array}{l}\text { Zinnwaldita } \\
\text { Zinnwaldita } \\
\text { Zinnwaldita } \\
\text { Muscovita }\end{array}$ & $\begin{array}{l}\text { Sienogranito } \\
\text { Albita- } \\
\text { microclínio } \\
\text { granito } \\
\text { Muscovita } \\
\text { Greisen } \\
\text { Veios }\end{array}$ & $\begin{array}{c}990 \pm 5 \\
985 \pm 4 \\
959 \pm 4 \\
987 \pm 1,9\end{array}$ & $\begin{array}{l}\text { Bettencourt et al. } \\
\qquad(2005 \mathrm{a})\end{array}$ \\
\hline & & $\mathrm{K}-\mathrm{Ar}$ & Zinnwaldita & Greisen & $961 \pm 17$ & Leite Jr. et al. (2001) \\
\hline \multirow{3}{*}{ Bom Futuro } & & $\mathrm{Ar}-\mathrm{Ar}$ & $\begin{array}{l}\text { Zinnwaldita } \\
\text { Zinnwaldita }\end{array}$ & $\begin{array}{l}\text { Pegmatito } \\
\text { Veios de } \\
\text { Quartzo }\end{array}$ & $\begin{array}{l}994 \pm 3 \\
993 \pm 3\end{array}$ & $\begin{array}{l}\text { Bettencourt et al. } \\
\qquad(2005 \mathrm{a})\end{array}$ \\
\hline & & $\mathrm{K}-\mathrm{Ar}$ & Zinnwaldita & $\begin{array}{l}\text { Veios de } \\
\text { Quartzo }\end{array}$ & $969 \pm 27$ & Leite Jr. et al. (2001) \\
\hline & & U-Th-Pb & Monazita & Greisen & $997 \pm 48$ & Souza et al. (2005) \\
\hline Manteiga & & Ar-Ar & Zinnwaldita & Mica greisen & $988 \pm 5$ & Souza et al. (2010) \\
\hline Oriente Novo & \multirow{4}{*}{$\begin{array}{l}\text { Suíte Intrusiva } \\
\text { Santa Clara } \\
(1082-1074 \mathrm{Ma})\end{array}$} & $\mathrm{K}-\mathrm{Ar}$ & $\begin{array}{l}\text { Zinnwaldita } \\
\text { Zinnwaldita } \\
\text { Zinnwaldita }\end{array}$ & $\begin{array}{c}\text { Greisen } \\
\text { Greisen } \\
\text { Veios de } \\
\text { Quartzo }\end{array}$ & $\begin{array}{c}1006 \pm 17 \\
981 \pm 35 \\
993 \pm 16\end{array}$ & \multirow[t]{2}{*}{ Leite Jr. et al. (2001) } \\
\hline Rio Branco & & & Zinnwaldita & Greisen & $976 \pm 30$ & \\
\hline Potosi & & $\mathrm{Ar}-\mathrm{Ar}$ & Muscovita & Mica greisen & $1053 \pm 3$ & $\begin{array}{l}\text { Bettencourt et al. } \\
(2005 \mathrm{a})\end{array}$ \\
\hline Oriente Novo & & $\mathrm{K}-\mathrm{Ar}$ & Biotita & Greisen & $993 \pm 40$ & Priem et al. (1971) \\
\hline Liberdade & $\begin{array}{c}\text { Suíte Intrusiva } \\
\text { São Lourenço- } \\
\text { Caripunas? } \\
(1314-1309 \mathrm{Ma})\end{array}$ & Ar-Ar & Muscovita & $\begin{array}{l}\text { Quartzo-mica } \\
\text { greisen }\end{array}$ & $1308 \pm 4,6$ & Esse Estudo \\
\hline
\end{tabular}

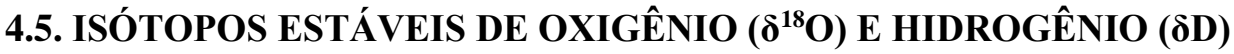

\subsubsection{Generalidades}

A sistemática de isótopos estáveis é parte importante na investigação de depósitos minerais, particularmente no que concerne à origem dos fluidos envolvidos no transporte dos metais e na alteração hidrotermal das rochas.

Isótopos estáveis são aqueles cuja composição varia em resposta a processos físico-químicos ou biológicos. Eles possuem diferentes propriedades termodinâmicas e o seu fracionamento é dependente da temperatura. Os isótopos estáveis mais utilizados na metalogênese são $\mathrm{H}, \mathrm{O}, \mathrm{C}$ e $\mathrm{S}$, e seu estudo constitui importante ferramenta na investigação de problemas relacionados com a formação de depósitos minerais.

A aplicação da geoquímica dos isótopos estáveis no estudo de depósitos minerais tem se baseado no entendimento dos mecanismos e do grau de fracionamento isotópico que acompanham vários processos geológicos. E uma vez complementados com estudos geoquímicos e mineralógicos, e interpretados dentro do contexto geológico em que o depósito mineral se formou, eles podem fornecer importantes subsídios acerca da fonte e temperatura de formação. Nesse sentido, os isótopos de $\mathrm{O}$ são 
geralmente estudados junto com os de $\mathrm{H}$, sendo comumente aplicados para rastrear a origem e evolução dos fluidos hidrotermais (Kelly e Rye 1979, Ohmoto 1986, Alderton 1989, Smith et al. 1996, Zheng 1992, Zhang et al. 1994, Taylor Jr. 1997).

\subsubsection{Resultados}

Amostras de cassiterita e quartzo, da mesma associação paragenética, encontrados nos veios mineralizados e nos quartzo-muscovita greisens com fluorita do depósito de estanho Liberdade foram submetidos a estudos de análise isotópica de oxigênio $\left(\delta^{18} \mathrm{O}\right)$, cujos resultados analíticos estão relacionados ao padrão V-SMOW (\%) e são mostrados na Tabela 4.6. Em ambos, a separação de fases minerais adequadas ao estudo isotópico foi facilitada devido à presença de cristais bem desenvolvidos.

Tabela 4.6. Amostras de minerais com seus respectivos valores de isótopos de $\delta^{18} \mathrm{O}$.

\begin{tabular}{ccccc}
\hline AMOSTRA & LOCAL & LITOTIPO & MINERAL & $\boldsymbol{\delta}^{\mathbf{1 8}}$ O SMOW (\%) \\
\hline CNRO-003B & Depósito Liberdade & Veio & Cassiterita & 1,6 \\
CNRO-003C & Depósito Liberdade & Veio & Quartzo & 9,6 \\
CNRO-003D & Depósito Liberdade & Greisen & Quartzo & 9,5 \\
CNRO-003G & Depósito Liberdade & Greisen & Cassiterita & 1,7 \\
\hline
\end{tabular}

Análises de isótopos de oxigênio, em geral, combinadas com as informações de inclusões fluidas, são largamente aplicadas no estudo de depósitos minerais de estanho, com a finalidade de elucidar problemas referentes à temperatura e fonte do fluido hidrotermal responsável pela mineralização (Kelly e Rye 1979, Campbel et al. 1984, Smith et al. 1996, Rios et al. 1998). A utilização do conteúdo isotópico de oxigênio em pares de minerais em equilíbrio isotópico também tem sido uma importante ferramenta aplicada a geotermometria (Taylor Jr. 1997, Alderton 1989, Zheng 1992, Zhang et al. 1994). Dentro desta perspectiva, selecionou-se para o estudo geotermométrico o par mineral quartzo-cassiterita, nos veios e nos quartzo-muscovita greisen com fluorita do depósito de estanho Liberdade, cujas composições isotópicas encontram-se na Tabela 4.6.

Os cálculos para a determinação da temperatura de cristalização dos pares quartzo-cassiterita foram elaborados com base na equação $1000 \ln \alpha=\left(\mathrm{A} \times 10^{6} / \mathrm{T}^{2}\right)+\left(\mathrm{B} \times 10^{3} / \mathrm{T}\right)+\mathrm{C}$, proposta por Zhang et al. (1994), cujos parâmetros isotópicos A, B e C são constantes para o sistema quartzo-cassiteritaágua (Tabela 4.7). O valor de $\alpha$ foi obtido através da relação $\alpha=1000+\delta_{\text {mineral A }} / 1000+\delta_{\text {mineral B }}$ (Faure 1986, Rollinson 1993) e o valor de T obtido é expresso em temperatura absoluta ou K, sendo necessário aplicar a correção para ${ }^{\circ} \mathrm{C}$.

Tabela 4.7. Fracionamento isotópico do oxigênio em cassiterita, cujos parâmetros isotópicos A, B e C foram utilizados para o cálculo da temperatura nos veios e greisens do Depósito de Estanho Liberdade, segundo os parâmetros estabelecidos por Zhang et al. (1994).

\begin{tabular}{c|ccccccc|c}
\hline \multirow{2}{*}{ Mineral } & \multicolumn{6}{|c|}{ QUARTZO-MINERAL } & \multicolumn{4}{c|}{ MINERAL-ÁGUA } & \multirow{2}{*}{ Temperatura } \\
\cline { 2 - 8 } & A & B & C & A & B & C & \\
\hline Cassiterita & $-6,87$ & 26,29 & $-15,49$ & 10,13 & $-26,09$ & 12,58 & $250-500^{\circ} \mathrm{C}$ \\
\hline
\end{tabular}

As informações geotermométricas obtidas no par quartzo-cassiterita dos veios indicam temperatura em torno de $430{ }^{\circ} \mathrm{C}$ para a cristalização da cassiterita (Tabela 4.8), enquanto que no quartzo-muscovita greisen com fluorita a temperatura foi de $445^{\circ} \mathrm{C}$ (Tabela 4.8).

Aplicou-se, ainda, para o cálculo indireto da composição isotópica $\delta^{18} \mathrm{O}$ do fluido hidrotermal fóssil, responsável pela deposição de cassiterita no depósito de estanho Liberdade, os valores de temperatura isotópica do par quartzo-cassiterita na equação $1000 \ln \alpha=\left(\mathrm{A} \times 10^{6} / \mathrm{T}^{2}\right)+\left(\mathrm{B} \times 10^{3} / \mathrm{T}\right)+\mathrm{C}$ (Zhang et al. 1994). Neste cálculo, as constantes A, B e C utilizadas estão relacionadas ao par mineral- 
água e expressos na Tabela 4.7. $\mathrm{O}$ valor da temperatura isotópica obtida deve ser para este cálculo, recorrigida de $\mathrm{K}$ para ${ }^{\circ} \mathrm{C}$, compõe a seguinte relação: $1000 \ln \alpha=\delta^{18} \mathrm{O}_{\text {(mineral) }}-\delta^{18} \mathrm{O}_{\text {(água) }}$, onde o valor de $\delta^{18} \mathrm{O}_{\text {(mineral) }}$ corresponde à composição isotópica de cassiterita. Os resultados obtidos estão apresentados na Tabela 4.8.

Tabela 4.8. Valores calculados para as temperaturas de cristalização e para a composição isotópica dos fluidos hidrotermais $\left(\delta^{18} \mathrm{O} \mathrm{H}_{2} \mathrm{O}\right)$.

\begin{tabular}{|c|c|c|c|c|c|}
\hline LOCAL & LITOTIPO & $\begin{array}{c}\text { PAR } \\
\text { MINERAL }\end{array}$ & $\begin{array}{c}\delta^{18} \text { O SMOW } \\
(\%)\end{array}$ & $\begin{array}{c}\text { TEMPERATURA } \\
\left({ }^{\circ} \mathrm{C}\right)\end{array}$ & $\begin{array}{c}\delta^{18} \mathrm{O} \mathrm{H}_{2} \mathrm{O} \\
(\%)\end{array}$ \\
\hline Depósito Liberdade & \multirow{2}{*}{ Veio } & Quartzo & 9,6 & \multirow{2}{*}{430} & \multirow{2}{*}{5,64} \\
\hline Depósito Liberdade & & Cassiterita & 1,6 & & \\
\hline Depósito Liberdade & \multirow{2}{*}{ Greisen } & Quartzo & 9,5 & \multirow{2}{*}{445} & \multirow{2}{*}{5,81} \\
\hline Depósito Liberdade & & Cassiterita & 1,7 & & \\
\hline
\end{tabular}

Paras análises aplicadas na correlação isotópica $\delta \mathrm{D} \times \delta^{18} \mathrm{O}$ foram utilizadas amostras de muscovita dos veios e do quartzo-muscovita greisen com fluorita (Tabela 4.9), cujos resultados analíticos estão relacionados ao padrão V-SMOW (\%). Em ambos, a separação de fases minerais adequadas ao estudo isotópico foi facilitada devido à presença de cristais bem desenvolvidos.

Tabela 4.9. Amostras de minerais com seus respectivos valores de isótopos de $\delta \mathrm{D}$.

\begin{tabular}{lcccccc}
\hline \multirow{2}{*}{ Amostras } & Mineral & Local & LF\# & $\begin{array}{c}\text { H } \\
\text { (\%o) }\end{array}$ & $\begin{array}{c}\text { D } \\
\text { (\%o) }\end{array}$ & $\begin{array}{c}\boldsymbol{\delta} \text { D fluido } \\
\text { (\%o) }\end{array}$ \\
\hline CNRO-003H & Mica & Veio & 16675 & 2,5 & -49 & -23 \\
CNRO-003F & Mica & Greisen & 16673 & 2,6 & -54 & -30 \\
\hline
\end{tabular}

A variação dos dados de $\delta \mathrm{D}$ do sistema hidrotermal está compreendida entre $-49 \%$ nos veios e $-54 \%$ nos greisens. Investigações realizadas sobre a composição isotópica da água $\left(\mathrm{H}_{2} \mathrm{O}\right)$ em fontes geotermais sugerem que o grau de alteração nos valores de $\delta \mathrm{D}$ depende da quantidade e temperatura do fluxo removido e do mecanismo de separação do fluxo (Viglino et al. 1985, in Xavier 1991). Considerando que os pares mica-quartzo-cassiterita de veio e mica-quartzo-cassiterita de greisen encontram-se em equilíbrio isotópico, aplicou-se a equação de fracionamento isotópico para muscovita proposta por Suzuoki \& Epstein (1976), cuja distribuição dos valores de $\delta \mathrm{D}$ fluido obtidos, dispostas no diagrama $\delta \mathrm{D}_{\text {fluido }} \mathrm{x} \delta^{18} \mathrm{O}_{\text {água }}$ segundo os parâmetros estabelecidos por Kerrich (1989), revela que as amostras se posicionam fora do domínio dos fluidos magmáticos e em direção ao campo dos fluidos meteóricos (Figura 4.4). Tal comportamento pode ser devido à interação de diferentes fluidos com densidades e composições isotópicas distintas.

\subsection{DISCUSSÕES}

O conjunto de dados isotópicos aqui apresentados sobre o depósito de estanho Liberdade nos permite avançar na compreensão dos processos magmáticos e metalogenéticos ocorridos naquela porção da Província Estanífera de Rondônia.

A assinatura isotópica $\mathrm{Sm}-\mathrm{Nd}$ dos fácies graníticos da Suíte Intrusiva Alto Candeias, encontrados no depósito de estanho Liberdade, revelam valores de $\varepsilon \mathrm{Nd}_{(\mathrm{t})}$ próximos a zero $(-0,94$ a $+0,88$ ) e idade modelo (TDM) entre 1,59 e 1,76 Ga. 


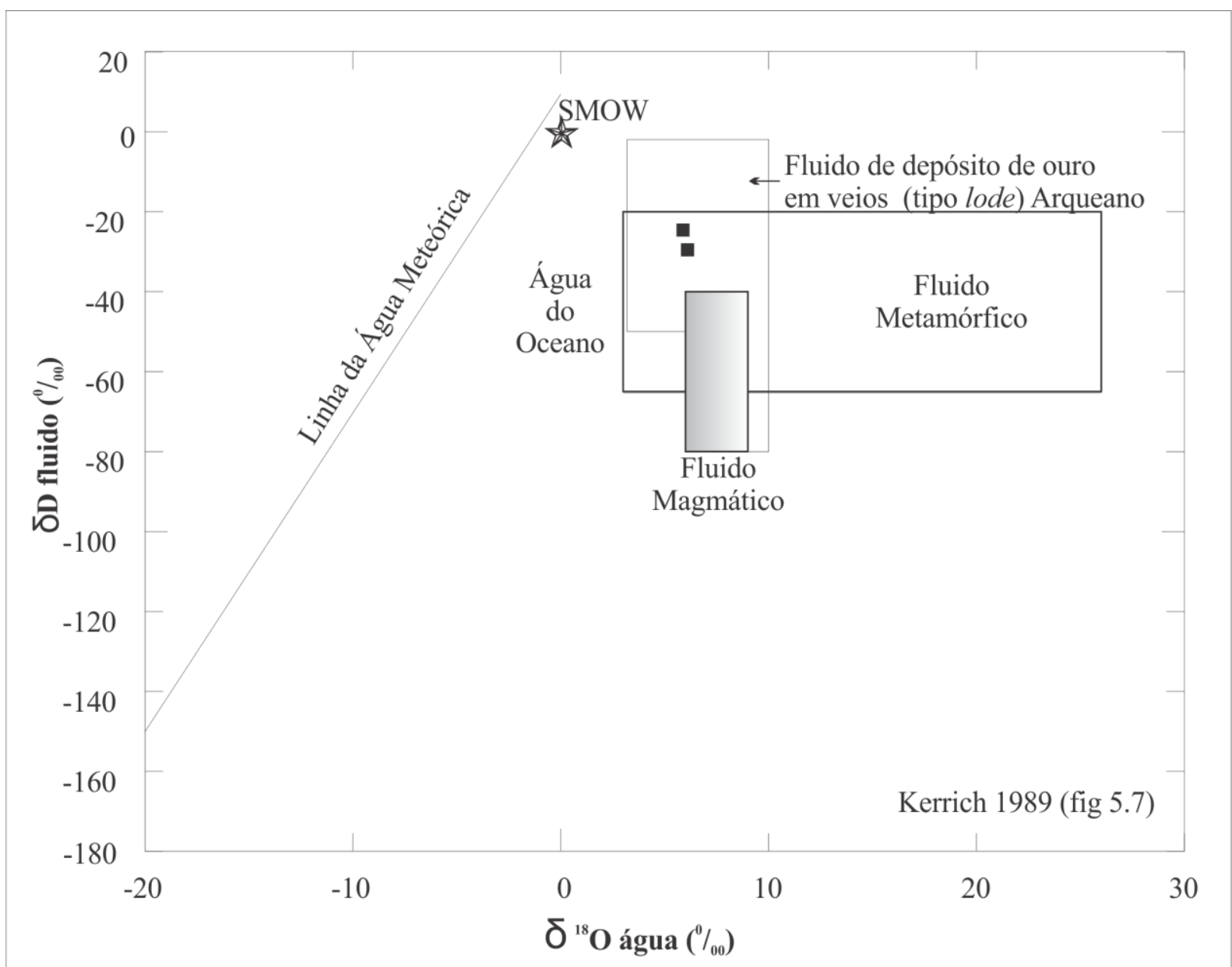

Figura 4.4. Diagrama $\delta \mathrm{D}_{\text {fluido }} \mathrm{x} \delta^{18} \mathrm{O}_{\text {água }}$ mostrando os dados de amostras de muscovita dos veios e greisen do depósito de estanho Liberdade, segundo Kerrich (1989).

Tais dados evidenciam que a evolução magmática ocorreu a partir de um único grupo isotópico, sob fusão parcial da antiga crosta continental Paleoproterozóica (Estateriano) durante o Mesoproterozóico (Ectasiano), cujo processo envolveu, em algum estágio, pouca mistura entre magmas félsicos crustais e magmas derivados do manto. Tais dados estão em conformidade com os dados isotópicos Sm-Nd conhecidos para as rochas da Suíte Intrusiva Alto Candeias (Scandolara 2006, Bettencourt et al. 2010).

Os dados isotópicos $\mathrm{U}-\mathrm{Pb}(1,36$ a $1,33 \mathrm{Ga})$, associados às características petrogenéticas marcadas pela assinatura de magmas do tipo $\mathrm{A}_{2}$ alojados em ambientes extensionais, denunciam que o magmatismo Alto Candeias está associado aos estágios finais colisionais da orogênese RondonianaSan Ignácio (Bettencourt et al. 2010). Por outro lado, Santos et al. $(2001,2002,2008)$ relacionam esse magmatismo a granitos de alto potássio, anorogênico do tipo $\mathrm{A}_{2}$, relacionados a um arco magmático tipo andino pertencente à fase final da orogenia Candeias (1371-1319 Ma), sendo colocada dentro da Província geocronológica Sunsás. Os dados aqui obtidos são consistentes com os dados U-Pb conhecidos para as rochas da Suíte Intrusiva Alto Candeias (Bettencourt et al. 1995, Bettencourt et al. 1997, Bettencourt et al. 1999a, Santos et al. 2000, Santos et al. 2002, Santos 2004, Santos et al. 2008, Bettencourt et al. 2010).

Segundo Bettencourt et al. (1999a e 1999b), a SIAC não é uma unidade especializada em estanho, porém pode hospedar fases magmáticas mais jovens que 1,3 Ga que se caracterizam por apresentar $\varepsilon N d$ entre $+0,33$ e $-3,25$ e TDM entre 1,66 e 1,73 Ga, favoravelmente portadoras desse metal, tais como as suítes intrusivas São Lourenço-Caripunas (1314-1309 Ma), Santa Clara (1082$1074 \mathrm{Ma}$ ) e Rondônia (995-974 Ma). Considerando a idade U-Pb de $1336 \pm 24 \mathrm{Ma}$, obtida neste 
trabalho para a fácies 3 da SIAC, o qual hospeda a mineralização, bem como os dados isotópicos de Ar-Ar que forneceram idade de resfriamento do sistema hidrotermal de $1308 \pm$ 4,6 Ma para o depósito de estanho Liberdade, ocorrido por volta de $400 \pm 50{ }^{\circ} \mathrm{C}$, as seguintes hipóteses podem ser consideradas:

1) $\mathrm{O}$ intervalo de tempo entre a idade $\mathrm{U}-\mathrm{Pb}$ de cristalização magmática da fácies granítica que encaixa as zonas mineralizadas (Fácies 3, amostra CNRO-001D=1336 $\pm 24 \mathrm{Ma}$ ) e a idade Ar-Ar de resfriamento da fase hidrotermal (1308 $\pm 5 \mathrm{Ma}$ ) é de cerca de $30 \mathrm{Ma}$, que pode ser considerado bastante elevado para vincular esta fase hidrotermal como exsolvida nas fases finais de evolução magmática da Fácies 3 da SIAC, o que, geralmente, é algo em torno de 4 Ma (Biondi 2003). Adicionalmente, os dados geocronológicos (Ar-Ar, U-Pb e K-Ar) disponíveis na Província Estanífera de Rondônia demonstram que as fases hidrotermais tardi a pós-magmáticas ricas em metais tem idades muito próximas às idades de cristalização das fases magmáticas rapakivis finais (Tabela 4.5);

2) A diferença de tempo caracterizada por análises das metodologias U-Pb e Ar-Ar utilizadas na pesquisa, poderiam estar associadas apenas às diferenças nas temperaturas de fechamento isotópico para os dois sistemas. O sistema isotópico U-Th- $\mathrm{Pb}$ em zircão tem uma temperatura de fechamento em torno de $750^{\circ} \mathrm{C}$ (Faure 1986, Lee et al. 1997, Cherniak e Watson 2001, Baldwin et al. 2007), enquanto que no sistema isotópico Ar-Ar em micas tem uma temperatura de fechamento entre $350^{\circ}$ e $400^{\circ} \mathrm{C}$ (Faure 1986, Richards e Noble 1998, McDougall e Harrison 1999). Entretanto, nota-se que as fácies graníticas identificadas na SIAC não apresentam características petrográficas e geoquímicas compatíveis com sistemas graníticos evoluídos e especializados em estanho. Além do mais, os depósitos polimetálicos presentes em Rondônia estão principalmente associados às fases magmáticas subvulcânicas rapakivis (Bettencourt et al. 1999a, Leite Junior 2002, Souza 2003, Sparrenberg 2003, Bettencourt et al. 2005b), ou seja, a magmas reduzidos;

3) A idade Ar-Ar de $1308 \pm 5$ Ma está definida sobre um platô de distribuição sem distúrbios termais no período de 995-991 Ma, o qual representa um intervalo de tempo com extensivo plutonismo granítico vinculado à Suíte Intrusiva Rondônia, a qual está vinculada a um dos mais importantes episódios magmáticos geradores de depósitos metálicos na Província Estanífera de Rondônia. Logo, é sugestivo dizer que a mineralização no depósito de estanho Liberdade não está associada a Suíte Intrusiva Rondônia, como sugerido anteriormente por Quadros (2007);

4) O efeito termal de médio a alto grau metamórfico associado à orogenia Rondoniana-San Ignácio (1,56-1,30 Ga; Tassinari et al. 2000, Bettencourt et al. 2010, Rizzotto et al. 2013, Scandolara et al. 2013a, Rizzotto et al. 2014), poderia ter afetado e perturbado, ou até mesmo "resetado", o sistema ${ }^{40} \mathrm{Ar}-{ }^{39} \mathrm{Ar}$, e então registrado apenas os estágios finais de resfriamento metamórfico regional na área do depósito Liberdade a $1308 \pm 5 \mathrm{Ma}$. Entretanto, duas considerações devem ser levadas em conta contra essa hipótese: a) a idade platô ${ }^{40} \mathrm{Ar}-{ }^{39} \mathrm{Ar}$ em mica obtida nessa pesquisa exibem um espectro sem distúrbios a $1308 \mathrm{Ma}$; b) os dados geocronológicos disponíveis sobre o evento metamórfico regional indicam idades U-Pb entre 1,37 e 1,32 Ga (Silva et al. 2002, Payolla et al. 2002, Souza et al. 2006, Santos et al. 2008, Scandolara et al. 2013a), enquanto que os dados ${ }^{40} \mathrm{Ar}-{ }^{39} \mathrm{Ar}$ para esse evento metamórfico datam entre 1316 e $1310 \mathrm{Ma}$, para registros em rochas do embasamento próximas da borda nordeste da SIAC (Tohver et al. 2005). Contudo, o final da orogenia Rondoniana-San Ignácio é marcado por um extensivo plutonismo granítico representado pelas suítes intrusivas tardi a pós-tectônicas Alto Candeias $(1,36-$ 1,33 Ga) e São Lourenço-Caripunas (1,31-1,30 Ga; Tassinari et al. 2000, Bettencourt et al. 
2010). Portanto, é pouco provável que os efeitos termais finais do evento metamórfico regional tenham afetado e modificado, ao ponto de "resetar" os registros de idades ${ }^{40} \mathrm{Ar}$ ${ }^{39} \mathrm{Ar}$ na parte central do volumoso magmatismo Alto Candeias;

5) Portanto, nós acreditamos que no depósito de estanho Liberdade a fase hidrotermal tarde a pós-magmática responsável pela mineralização não está associada à evolução magmática do sistema Alto Candeias e nem tão pouco ao sistema Rondônia ou Younger Granites. Tal fase hidrotermal estaria sim associada a um evento magmático que aparentemente não aflora na parte central da SIAC, o qual ainda não foi devidamente estudado e teria correlação temporal com a suíte intrusiva São Lourenço-Caripunas.

Em relação aos isótopos estáveis de $\delta^{18} \mathrm{O}$, pode-se visualizar que os valores de $\delta^{18} \mathrm{O}$ para o quartzo e cassiterita são constantes e equivalentes a 9,5 a 9,6 \% e 1,6 e 1,7 \%, respectivamente. A variação nos valores isotópicos entre quartzo e cassiterita é indicativa de processo de fracionamento isotópico durante a ascensão dos fluidos responsáveis pela mineralização. Como o fracionamento isotópico é uma função direta da temperatura (Taylor Jr. 1968, Taylor Jr. 1978, Faure 1986), a diferença isotópica observada entre o par quartzo-cassiterita sugere que o abaixamento da temperatura nos sistemas fluidos mineralizados do depósito de estanho Liberdade foi um dos fatores mais importantes para a precipitação da cassiterita.

A composição isotópica $\delta^{18} \mathrm{O}$ indireta do fluido hidrotermal, coexistente com quartzo e cassiterita dos veios e greisens (5,54 e 5,81\%o, respectivamente) são próximos e estão dentro do intervalo isotópico fluidos de derivação magmática, cujo $\delta^{18} \mathrm{O}$ está entre 5,5 e 10,0\% (Taylor Jr. 1974). Tais características isotópicas indicam que o quartzo e a cassiterita foram precipitados em um mesmo intervalo de temperatura $\left(430\right.$ a $\left.450{ }^{\circ} \mathrm{C}\right)$ e, provavelmente, a partir do mesmo fluido hidrotermal de origem magmática. É provável que o abaixamento da temperatura e alteração da composição isotópica tenha sido devida à interação entre fluidos diferentes (meteórico x hidrotermal).

Por fim, a partir dos dados de isótopos de $\delta \mathrm{D}$, juntamente com os dados de $\delta^{18} \mathrm{O}$, sugere-se que o sistema hidrotermal em estudo reflete composições isotópicas relacionadas a mistura de fluidos magmáticos e meteóricos, com pouco ou nenhum aporte de fluidos metamórficos. 


\section{CAPÍTULO 5}

\section{CONCLUSÕES}

Na Província Estanífera de Rondônia as fases magmáticas que hospedam as mais expressivas concentrações metálicas ( $\mathrm{Sn}, \mathrm{W}, \mathrm{Pb}, \mathrm{Cu}, \mathrm{Nb}, \mathrm{Ta}$ ), além de flúor e gemas, estão associadas principalmente aos três últimos eventos magmáticos ocorridos entre 1314 e 991 Ma (Suíte Intrusiva São Lourenço-Caripunas - 314-1309 Ma, Suíte Intrusiva Santa Clara - 1082-1074 Ma e Suíte Intrusiva Rondônia ou Young Granites de Rondônia - 95-991 Ma; Kloosterman 1968, Priem et al.1966, Priem et al. 1971, Isotta et al. 1978, Priem et al 1989, Bettencourt et al.1999a, Bettencourt et al. 2010). Essas mineralizações metálicas, em especial a mineralização estanífera, são encontradas também nas suítes graníticas rapakivi mais antigas, nos eventos magmáticos ocorridos entre $1606 \mathrm{e}$ 1329 Ma (Suíte Intrusiva Serra da Providência - 1606-1526 Ma, Suíte Intrusiva Santo AntônioTeotônio - 1406-1387 Ma e Suíte Intrusiva Alto Candeias - 1356-1329 Ma; Bettencourt et al.1999a, Santos et al. 2008, Bettencourt et al. 2010). Porém, nesse caso, esses sistemas magmáticos são hospedeiros de mineralizações, relacionadas principalmente as suítes graníticas mais jovens (Bettencourt et al.1999a).

Em geral, esses sistemas magmáticos são extremamente evoluídos e fracionados, ricos em voláteis e elementos incompatíveis (metais), alojados em níveis crustais rasos e, aparentemente, controlados por falhas transcrustais atuando em regime transtensivo (Bettencourt et al. 1999a, Okida 2001, Leite Jr. 2002, Sparrenberger 2003, Souza 2003).

As observações de campo e os estudos petrológicos aqui apresentados nos permitem inserir as fácies graníticas identificadas na área do depósito de estanho Liberdade como pertencentes à Suíte Intrusiva Alto Candeias, cujas idades U-Pb estão entre 1336,0 e 1356,9 Ma. Segundo Bettencourt et al. (1999a), a Suíte Intrusiva Alto Candeias não representa uma unidade com potencialidade para ser fonte de mineralizações no contexto da Província Estanífera de Rondônia, sendo apenas uma rocha hospedeira. Por outro lado, a idade Ar-Ar de $1308 \mathrm{Ma}$, associada aos dados de isótopos estáveis $\left(\delta^{18} \mathrm{O}\right.$ e $\delta \mathrm{D}$ ), obtidos na paragênese mineral dos greisens, nos conduz a considerar que a mineralização de estanho do depósito Liberdade estaria associada a eventos magmáticos mais jovens que os eventos finais tardi a pós-magmáticos da Suíte Intrusiva Alto Candeias, cuja idade é contemporânea aos eventos relacionados ao magmatismo responsável pela formação das rochas pertencentes à Suíte Intrusiva São Lourenço-Caripunas (1314-1309 Ma).

Portanto, consideramos que a mineralização de estanho do depósito Liberdade é resultado da simples combinação evolutiva de uma intrusão granítica em níveis crustais rasos, seguida da liberação de uma fase hidrotermal ácida responsável pela greisenização. Tal evento magmático foi, provavelmente, alojado aproveitando a reativação de falhas e fraturas. A evolução desses sistemas magmáticos ácidos extremamente fracionados envolve a geração de estágios de separação de fases, conforme diminui as condições de temperatura e pressão, proporcionando a formação de fases imiscíveis (magmática e hidrotermal) coexistindo em aparente equilíbrio durante o final do estágio magmático (Sillitoe et al. 1975, Plimer 1987, Hedenquist e Lowenstern 1994, Johnson et al. 2002). Nas fases finais de evolução magmática, onde o magma residual encontra-se enriquecido em voláteis e elementos incompatíveis, o magma residual exsolve a fase fluida hidrotermal, a qual incorpora voláteis e metais incompatíveis e desloca-se para as partes de cúpula da intrusão granítica (Manning 1982, Pollard e Taylor 1986, Hedenquist e Lowenstern 1994). A evolução desse processo culmina com as transformações tardi a pós-magmáticas responsáveis pela formação de greisens e veios 
mineralizados, cujas gêneses estão em conformidade com aquelas descritas por Plimer (1987). O processo de greisenização se desenvolve, principalmente, ao longo dos contatos litológicos e planos de falhas e fraturas desenvolvidas sobre a cúpula granítica, gerando metassomatismo no contato com as rochas encaixantes. A interação entre fluidos distintos (hidrotermal $\mathrm{x}$ meteórico) favorece $\mathrm{o}$ rebaixamento da temperatura e altera as condições de $\mathrm{pH}$, Eh e $\mathrm{fO}_{2}$ no sistema, favorecendo a precipitação do conteúdo mineral-metálico formando greisens e veios de quartzo contendo cassiterita, arsenopirita, entre outros minerais. A Figura 5.1 esboça uma ideia simplificada da estruturação do depósito de estanho Liberdade.

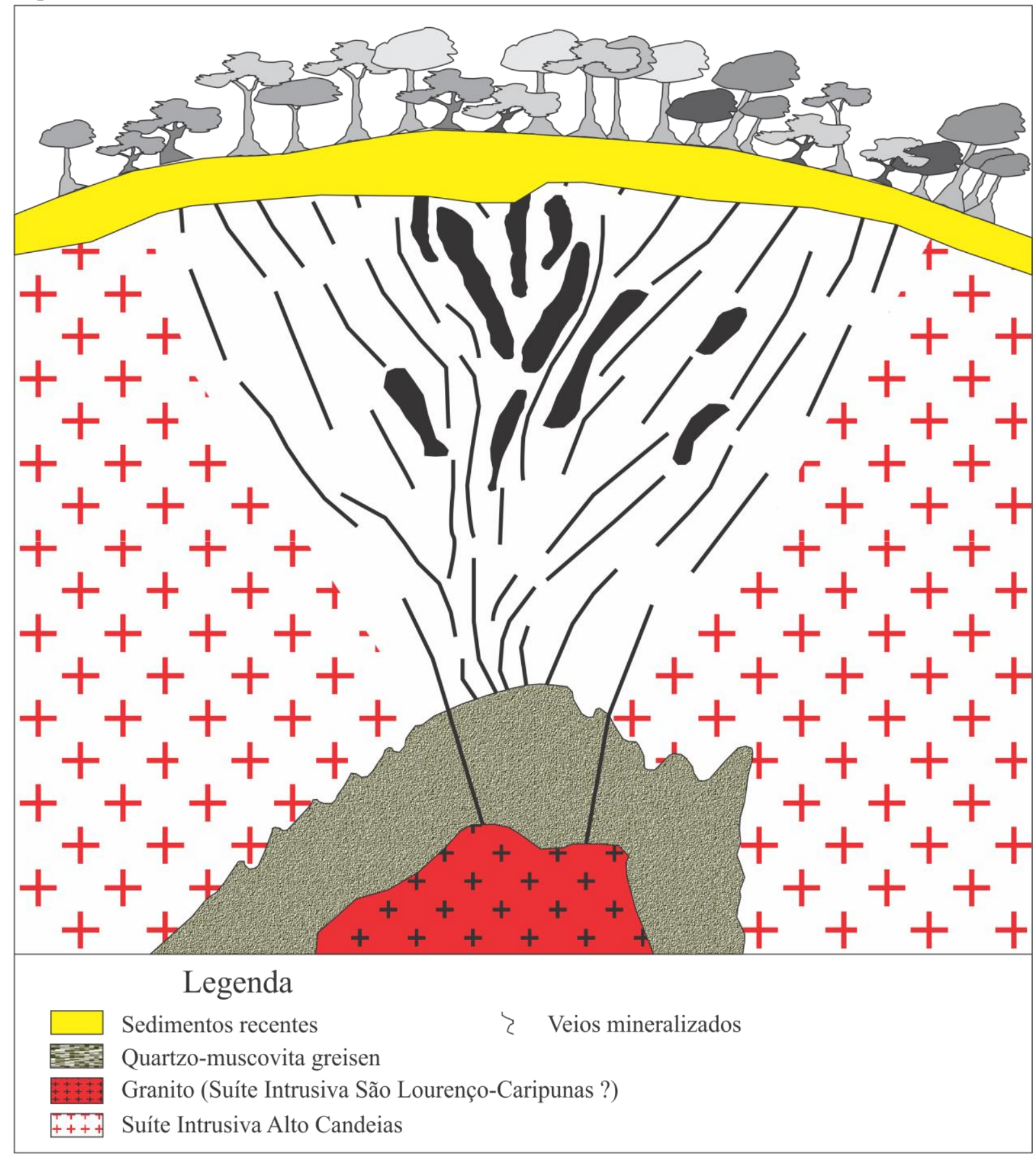

Figura 5.1. Modelo esquemático de compartimentação geológica e evolução metalogenética proposto para o depósito de estanho Liberdade.

As rochas graníticas da área em torno do depósito de estanho Liberdade apresentam três características particulares que merecem destaque: a) presença dos fácies graníticos dos tipos biotita- 
hornblenda granito rapakivi e hornblenda-biotita granito inequigranular médio, ambas apresentando caráter subalcalino, metaluminoso e moderado grau de fracionamento entre os ETR leves e pesados; b) presença de um terceiro fácies granítico do tipo biotita granito inequigranular fino, de caráter subalcalino, peraluminoso e alto grau de fracionamento entre os ETR leves e pesados. As três fácies apresentam características geoquímicas compatíveis aos granitos do tipo A (Collins et al. 1982, Whalen et al. 1987, Eby 1992), subtipo A (Eby 1992), alojados em ambiente tardi a pós-colisional. As Fácies 1 e 2, apresentam características de granitos do tipo A ferrosos reduzidos (Frost et al. 2001, Dall'Agnol e Oliveira 2007), enquanto que a Fácies 3 apresenta característica de granitos do tipo A ferrosos oxidados ou cálcio-alcalinos (Frost et al. 2001, Dall'Agnol e Oliveira 2007), sendo interpretada como produto de pulsos magmáticos distintos, porém, de composição química similar ao das outras duas fácies ou trata-se da interação com fluidos hidrotermais de derivação magmática que pode ter modificado a química da rocha e, assim, fornecer uma leitura errada. Segundo Dall'Agnol e Oliveira (2007), essas características geoquímicas nos permitem interpretar que as rochas da SIAC fazem parte da série ilmenita.

O biotita granito inequigranular fino (Fácies 3) é encontrado apenas na frente de extração mineral, ocorrendo associado a zonas de greisens, veios e vênulas mineralizados. Entretanto, os dados $\mathrm{U}-\mathrm{Pb}$ revelaram idade de $1336 \pm 24 \mathrm{Ma}$ para a Fácies 3, com presença de $\mathrm{Pb}$ comum, provavelmente associado a interferência metassomática dos fluidos hidrotermais, elevando assim o erro analítico. Embora haja alguma diferença geoquímica e petrográfica entre as Fácies 1 e 2 e a Fácies 3, tais características não nos permite inserir com segurança o tipo petrográfico biotita granito inequigranular fino (Fácies 3) como representante da Suíte intrusiva São Lourenço-Caripunas (1314-1309 Ma), intrusiva nas rochas graníticas (Fácies 1 e 2) da Suíte Intrusiva Alto Candeias (1356-1329 Ma). Faz-se necessário então um refinamento das investigações geocronológicas sobre o biotita granito inequigranular fino. Porém, neste trabalho ele é considerado como uma Fácies da Suíte Intrusiva Alto Candeias.

Em geral, esses sistemas hidrotermais tardi a pós-magmáticos permanecem aquecidos por um razoável período de tempo, cerca de $4 \mathrm{Ma}$ (Biondi 2003), funcionando como células convectivas ao redor do plúton granítico promovendo eficaz processo de alteração hidrotermal, intensa venulação e o desenvolvimento de estruturas dos tipos comb, ribbon e stocksheider (Campbel et al. 1984, Burnham 1985, Pollard e Taylor 1986, Samson 1990, Smith et al. 1996). Porém, é muito improvável que esse sistema tenha permanecido aquecido por cerca de $30 \mathrm{Ma}$, o que inviabiliza a hipótese de que a fonte da mineralização tenha sido o magmatismo responsável pela geração das rochas da Suíte Intrusiva Alto Candeias. É possível que os dados geológicos de mapeamento na região, em escala disponível (1:1.000.000), não permitam identificar registros de rochas pertencentes ou correlatas, temporalmente, a Suíte Intrusiva São Lourenço-Caripunas.

No depósito de estanho Liberdade a diferença isotópica $\left(\delta^{18} \mathrm{O}\right)$ entre quartzo e cassiterita pode ser produto da interação de fluidos magmáticos com fluidos meteóricos isotopicamente mais leves durante a greisenização, favorecendo o rebaixamento do $\delta^{18} \mathrm{O}$ acompanhado da consequente diminuição da temperatura. Tais mecanismos também são considerados como os mais importantes na precipitação do conteúdo metálico (Sn) em outros depósitos em Rondônia (Leite Jr. 2002, Souza 2003, Sparrenberger 2003). Os estudos isotópicos $\left(\delta^{18} \mathrm{O}\right)$ demonstram ainda que a temperatura de cristalização da cassiterita nos sistemas mineralizados do depósito Liberdade é da ordem de 430 a 445 ${ }^{\circ} \mathrm{C}$, o que também está em acordo com as informações sobre a temperatura de cristalização dos pares quartzo-cassiterita-wolframita do depósito de Bom Futuro, Rondônia (Souza 2003, Souza e Botelho 2009). Os dados de isótopos de $\delta \mathrm{D}$, juntamente com os dados de $\delta^{18} \mathrm{O}$, sugerem que o sistema hidrotermal em estudo reflete composições isotópicas relacionadas a interação (mistura) entre fluidos magmáticos e meteóricos, com pouco ou nenhum aporte de fluidos metamórficos. 
O estudo de química mineral revelou que a cassiterita no depósito Liberdade exibe igualmente zoneamento e composição análoga aos estudos realizados no depósito de Bom Futuro, Rondônia (Souza 2003, Souza e Botelho 2009). O zoneamento é caracterizado pela alternância de faixas de cores castanho claro, vermelho, castanho escuro, marrom e marrom escuro. As faixas castanho claro a vermelho, apresentam conteúdos maiores em $\mathrm{SnO}_{2}$ e menores em $\mathrm{FeO}$ (total) $, \mathrm{TiO}_{2}, \mathrm{Nb}_{2} \mathrm{O}_{5}$ e $\mathrm{WO}_{3}$, enquanto que as faixas castanho escuro a marrom escuro são ricas em $\mathrm{FeO}_{\text {(total) }}, \mathrm{TiO}_{2}, \mathrm{Nb}_{2} \mathrm{O}_{5}$ e $\mathrm{WO}_{3}$, empobrecendo-se em $\mathrm{SnO}_{2}$. O principal mecanismo para explicar tais variações composicionais é controlado por substituições iônicas e substituições por acoplamento, controlados pelo progressivo abaixamento da temperatura, e exemplificado pelas seguintes expressões: a) $2 \mathrm{Sn}^{4+}+\mathrm{O}^{2+} \leftrightarrow \mathrm{Ti}^{4+}+\mathrm{Fe}^{3+}$ $+\mathrm{OH}^{-}$, b) $3(\mathrm{Sn}){ }^{4+} \leftrightarrow 2(\mathrm{Nb}, \mathrm{Ta})^{5+}+\mathrm{Fe}^{2}$ (Cerný e Ercit 1985, Neiva 1996, Murciego et al. 1997, Möller et al. 1988).

O depósito de estanho Liberdade está localizando entre um corredor estrutural. Esse corredor estrutural é formado por duas grandes estruturas principais, de direção NW-SE (Y(D)) e NE-SW (tension gashes ou T), respectivamente. No sistema de veios do depósito de estanho Liberdade predominam feições de caráter rúptil-dúctil, caracterizando o sistema de cisalhamento como transcorrente rúptil-dúctil (Ramsey 1980), onde os corpos mineralizados do depósito de estanho Liberdade constituem em um enxame de veios com nítido controle estrutural. As estruturas mineralizadas mostram duas direções principais, onde o primeiro trend representa a direção principal onde a faixa mineralizada em cassiterita foi estabelecida e o segundo corresponde a fraturas menores que foram mineralizadas, onde nas interseções entre as duas direções ocorrem corpos em forma de charutos verticalizados com mineralização de mais alto teor, devido ao maior fluxo hidrotermal ao longo dessa zona. 


\section{CAPÍTULO 6}

\section{REFERÊNCIAS BIBLIOGRÁFICAS}

Adamy A. (org.). 2010. Geodiversidade do Estado de Rondônia. Porto Velho: CPRM, 337 p. + 1 DVD.

Alderton D.H.M. 1989. Oxygen isotope fractionation between cassiterite and water. Mineralogical Magazine, 53:373-376.

Almeida F.F.M. 1974. Evolução tectônica do Craton do Guaporé comparada com o Escudo Báltico. Revista Brasileira de Geociências, 4(3):191-204.

Almeida F.F.M. 1978. A evolução dos cratons Amazônico e São Francisco comparada com homólogos do hemisfério norte. In: Anais do 30º Congresso Brasileiro de Geologia, SBG, Recife, 6:2393-2407.

Almeida F.F.M., Neves B.B.B., Fuck R.A. 1977. Províncias Estruturais Brasileiras. In: SBG, VIII Simpósio de Geologia do Nordeste, Campina Grande, Atas, p. 363-391.

Almeida F.F.M., Hasui Y., Neves B.B.B., Fuck R.A. 1981. Brazilian structural provinces: an introduction. Earth Science Review, 17:1-29.

Amaral G. 1974. Geologia Pré-Cambriana da região Amazônica. IG-USP. São Paulo, Tese de Livre Docência, $212 \mathrm{p}$.

Amaral G. 1984. Províncias do Tapajós e Rio Branco. In: F.F.M. Almeida e Y. Hasui (Coord.). O PréCambriano do Brasil. Ed. Edgard Blücher. São Paulo. 2:6-35.

Amorim J.L., Rizzoto G.J., Scandolara J.E. 1999a. Complexo Jamari, sudeste do cráton amazônico: reavaliação do contexto geotectônico. In: Anais do 7ํㅗ Simpósio Nacional de Estudos Tectônicos, Lençóis (BA), SBG (BA), 1:28-30.

Amorim J.L., Rizzoto G.J., Scandolara J.E. 1999b. Terreno Jamari, região central de Rondônia: evidências de processos tafrogenéticos que precedem a convergência do início do mesoproterozóico no seguimento sudeste do cráton Amazônico. In: Boletim de Resumos Expandidos do $7^{\circ}$ Simpósio de Geologia da Amazônia, Manaus, SBG (NO), 270-273.

Bahia R.B.C. 1997. A Formação Palmeiral (Proterozóico Superior) na Serra dos Pacaás Novos, oeste de Rondônia. 1997. Dissertação de Mestrado, Centro de Geociências, Universidade Federal do Para, Belém, 88 p.

Baldwin J. A., Brown M., Schmitz M.D. 2007. First application of titanium-in-zircon thermometry to ultrahightemperature metamorphism. Geology, 35(4):295-298.

Bettencourt J.S. and Dall'agnol R. 1987. The rondonian tin-bearing anorogenic granites and associated mineralization. In: International Symposium on Granites and Associated Mineralizations. Salvador, Excursion Guide, SME-BA, 144 p. il. p. 49-87.

Bettencourt J.S., Batezelli A., Thomazella H.R., Silva L.F., Muzzolon R., Leite Jr. W.B. 1995. Mapa geológico do depósito de estanho de Bom Futuro. EBESA. Relatório interno.

Bettencourt J.S., Onstott T.C., Jesus T., Teixeira W. 1996. Tectonic interpretation of ${ }^{40} \mathrm{Ar} /{ }^{39} \mathrm{Ar}$ ages on country rocks from the central sector of the Rio Negro-Juruena Province, Southwest Amazonian Craton. International Geology Review, 38:42-56.

Bettencourt J.S., Tosdal R.M., Leite Jr. W.R., Payolla B.L. 1997. U-Pb, Sm-Nd, Pb-Pb and Rb-Sr isotopic contraints on the origin of the rapakivi granites of Rondônia. In: South-Amarican Symposium on Isotope Geology (SSAGI). São Paulo. Extended Abstracts, p. 47-48.

Bettencourt J.S., Tosdal R.M., Leite Jr. W.R. and Payolla B.L. 1999a. Mesoproterozoic rapakivi granites of the Rondônia Tin Province, southwestern border of the Amazonianian craton, Brazil - I. Reconnaissance U-Pb geochronology and regional implications. Precambriam Research, 95:41-67.

Bettencourt J.S., Payolla B.L., Leite Jr. W.R., Tosdal R.M., Spiro B. 1999b. Mesoproterozoic rapakivi granites of the Rondônia Tin Province, southwestern border of the Amazonianian craton, Brazil - III. Reconnaissance $\mathrm{Nd}, \mathrm{Sr}, \mathrm{O}, \mathrm{Pb}$ isotopic geochemistry ans regional implications. In: B. Babarian (eds.). The origin of granites 
and related rocks. Fourth Hutton Symposium, Clermont-Ferrand, France. Documents du BRGM 290, Abstracts, p. 132.

Bettencourt J.S., Sparrenberger I., Leite Jr. W.R., Payolla B.L., Onoe A.T., Tosdal R. M. 2005a. ${ }^{40} \mathrm{Ar} /{ }^{39} \mathrm{Ar}$ step heating laser system dating of zinnwaldite and muscovite from tin deposits of the Rondônia Tin Province, Brazil: evidence for multiple mineralization episodes. In: I Simpósio Brasileiro de Metalogênese, MME/SBG/SEG, Gramado, CD-ROM.

Bettencourt J.S., Leite Jr. W.R., Goraieb C.L., Sparrenberger I., Bello R.M.S., Payolla B.L. 2005b. Snpolymetallic greisens-type deposists associated with late-stage rapakivi granites, Brazil: fluid inclusion and stable isotope characteristics. Lithos, 80:363-386.

Bettencourt J.S., Payolla B.L., Tosdal R.M., Wooden J.L., Leite Jr. W.B., Sparrenberger I. 2006. SHRIMP-RG $\mathrm{U}-\mathrm{Pb}$ zircon geochronology of gneiss from the Rio Crespo Intrusive Suite, SW Amazonian Craton, Rondônia, Brazil: New insight about protolith crystallization and metamorphic ages. In: South American Symposium on Isotope Geology, 5. p. 49-52

Bettencourt J.S., Leite Jr. W.B., RUIZ A.S., Matos R., Payolla B.L., Tosdal R.M. 2010. The Rondonian-San Ignacio Province in the SW Amazonian Craton: An overview. Journal of South American Earth Sciences, 29:28-46.

Biondi J.C. 2003. Processos metalogenéticos e os depósitos minerais brasileiros. São Paulo, Oficina de Textos, $528 \mathrm{p}$.

Bizzi L.A., Schobbenhaus C., Vidotti R.M., Gonçalves J.H. (eds.). 2004. Geologia, tectônica e recursos minerais do Brasil: texto, mapas e SIG. Serviço Geológico do Brasil - CPRM, 692 p.

Boynton W.V. 1984. Cosmochemistry of the rare earth elements: meteorite studies. In: P. Henderson (eds.). Rare earth element geochemistry (Developments in Geochemistry 2). Elsevier, Amsterdam, p. 63-114.

Buchan K.L., Ernst R.E., Hamilton M.A., Mertanen S., Pesonen L.J., Elming S. 2001. Rodinia: the evidence from integrated paleomagnetism and U-Pb geochronology. Precambrian Research, 110:9-32.

Bühn B., Pimentel M.M., Matteini M., Dantas E.L. 2009. High spatial resolution analysis of $\mathrm{Pb}$ and U isotopes for geochronology by laser ablation multi-collector inductively coupled plasma mass spectrometry (LA-MCICP-MS). Anais da Academia Brasileira de Ciências 81, 1-16.

Burnham C.W. 1985. Energy realease in subvolcanic enviromentes: implications for breccia formation. Economic Geology, 80:1515-1522.

Campbell A., Rye D.M., Peterson U. 1984. A hydrogen and oxygen isotope study of the San Cristobal mine, Peru: implications of the role of water to rock ratio for the genesis of wolframite deposits. Economic Geology, 79:1818-1832.

Cerný P. and Ercit T.S. 1985. Some recent advances in the mineralogy and geochemistry of $\mathrm{Nb}$ and Ta in rareelement granitic pegmatites. Bulletin of Mineralogy, 108:499-532.

Charoy B. 1979. Définition et importance des phénomènes deutériques et des fluides associés dans les granites: conséquences métallogéniques. Institut National Polytechique de Lorraine, Nancy, thèse PhD. Science de la Terre, Mémoire no 37, 364 p.

Cheilletz A., Bertrand J.M., Charoy B., Moulahoum O., Archibald D.A., Boullier A.M., 1992. Geochimie et geochronologie $\mathrm{Rb}-\mathrm{Sr}, \mathrm{K}-\mathrm{Ar},{ }^{40} \mathrm{Ar} /{ }^{39} \mathrm{Ar}$ de complexes granitiques pan-africains de la region de tamanrasset (Algerie): relations avec les mineralisations $\mathrm{Sn}-\mathrm{W}$ associees et evolution tectonique du Hoggar central. Bulletin Societe Geologique de France 163, 733-750.

Cherniak D.J. and Watson E.B. 2001. Pb diffusion in zircon. Chemical Geology, 172(1-2):5-24.

Collins W.J., Beams S.D., White A.J.R., Chappell B.W. 1982. Nature and origin of A-type granites wiyh particular reference to southeastern Australia. Contributions to Mineralogy and Petrology, 80:189-200.

Condie K.C. 2001. Continental growth during formation of Rodinia at 1.35-0.9 Ga. Gondwana Research, 4(1):516

Cordani V.G. and Neves B.B.B. 1982. The geologic evolution of South America during the archean and early proterozoic. Revista Brasileira de Geociências, 12(1-3):78-88.

Cordani V.G., Tassinari C.C.G., Teixeira W., Basei M.A.S., Kawashita K. 1979. Evolução tectônica da Amazônia com base nos dados geocronológicos. In: Actas do $2^{\circ}$ Congress de Geologica de Chileno, Arica, Chile, 4:137-148.

Costa J.B.S. e Hasui Y. 1997. Evolução geológica da Amazônia. In: M.L. Costa e R.S. Angélica (Coord.). Contribuições à Geologia da Amazônia. FINEP/SBG-NO, Belém, p. 15-90. 
Costa J.B.S., Bemerguy R.L., Hasui Y., Borges M.S., Ferreira Jr. C.R.P., Bezerra P.E.L., Fernandes J.M.G., Costa M.L. 1996. Neotectônica da Região Amazônica: aspectos estruturais, tectônicos, geomorfológicos e estratigráficos. Geonomos, v. 4, n. 2, p. 23-44.

Costi H.T., Horbe A.M.C., Borges R.M.K., Dall'Agnol R., Rossi A., Sighnolfi G. 2000. Mineral chemistry of cassiterites from Pitinga Province, Amazonian Craton, Brazil. Revista Brasileira de Geociências, 30(4):775782.

Cox K.G., Bell J.D. and Pankhurst R.J. 1979. The interpretation of igneous rocks. George Allen \& Unwin, London, 450p.

Creaser R. A., Price R.C., Wormald R.J. 1991. A-type granites revisited: assessment of a residual-source model. Geology, 19:163-166.

D’Agrella-Filho M., Pacca I.I.G., Siqueira R., Elming S.A., Teixeira W., Bettencourt J.S., Geraldes M.C. 2001. Preliminary paleomagnetic results from metabasic and sedimentary rocks from the Amazonian Craton: tectonic implications for the Rodinia supercontinent. In: J.S. Bettencourt W., Teixeira I.G., Pacca, Geraldes M.C., Sparrenberger I. (eds.). Geology of the SW Amazonian Craton: State-of-the-Art. Institute of Geosciences - University of São Paulo - Brazil, IGCP Project 426. Workshop, p. 155-158.

Dall'Agnol R. and Oliveira D.C. 2007. Oxidized, magnetite-series, rapakivi-type granites of Carajás, Brazil: Implications for classification and petrogenesis of A-type granites. Lithos, 93(3):215-233.

Dall'Agnol R., Teixeira N.P., Rämö O.T., Moura C.A.V., Macambira M.J.B., Oliveira D.C. 2005. Petrogenesis of the Paleoproterozoic, rapakivi, A-type granites of the Archean Carajás Metallogenic Province, Brazil. Lithos, 80, 101-129.

Dalrymple G.B., Alexander Jr. E.C., Lanphere M.A., Kraker G.P. 1981. Irradiation of samples for ${ }^{40} \mathrm{Ar} /{ }^{39} \mathrm{Ar}$ dating using the Geological Survey TRIGA Reactor. U.S. Geological Survey, Professional Paper 1176, 55 p.

De La Roche H., Leterrier J., Grandclaude P. and Marchal M. 1980. A classification of volcanic and plutonic rocks using R1-R2 diagram and major element analyses - its relationships with current nomenclature. Chemical Geology, 29, 183-210.

DePaolo D.J. 1981. Neodymium isotopes in the Colorado front range and crustal-mantle evolution in the Proterozoic. Nature, 291:193-196.

Dickin A.P. 2005. Radiogenic isotope geology. Cambridge University Press, New York, 2nd, 492 p.

Eby G.N. 1990. The A-type granitoids: a review of their occurrence and chemical characteristics and speculations on their petrogenesis. Lithos, 26:115-134.

Eby G.N. 1992. Chemical subdivisions of A-type granitoids: Petrogenesis and tectonic implications. Geology 20, 614-644.

Fallick A.E., Macaulay I., Haszeldine R.S. 1993. Implications of linearly correlated oxygen and hydrogen isotopic compositions for kaolinite and illite in the Magnus sandstone, North Sea. Clays and Clay Minerals, 41(2): $184-190$

Faure G. 1986. Principles of isotopic geology. John Wiley \& Sons, New York. 2nd. 589 p.

Foord E.E. 1982. Minerals of tin, titanium, niobium and tanta lum in granitic pegmatites. In: Cerný P., (eds.). Granite pegmatites Science and Industry Mineralogical Association of Canada, Short Course Handbook, 8:187-238.

Foord E.E. and Cook R.B. 1989. Mineralogy and paragenesis of the McAllister Sn-Ta-bearing pegmatite, Coosa County, Alabama. Canadian Mineral, 27:93-105.

Frost C.D., Frost B.R., Chamberlain K.R., Edwards B. 1999. Petrogenesis of the 1.43 Ga Sherman batholith, SE Wyoming, USA: a reduced, rapakivi-type anorogenic granite. Journal of Petrology, 40, 1771-1802.

Frost B.R., Barnes C.G., Collins W.J., Arculus R.J., Ellis D.J., Frost C.D. 2001. A geochemical classification for granitic rocks. Journal of Petrology, 42(11):2033-2048.

Gaudette H.E. and Olszewski Jr. W.J. 1985. Geochronology of the basement rocks, Amazonas territory, Venezuela and the tectonic evolution of the western Guiana shield. Geologie Minjnbouw, 64:131-144.

Geraldes M.C. and Nogueira C.C. 2013. Rondonia Tin Province, SW Amazonian Craton Revisited: geochronology, magmatic processes and tectonic setting. In: $13^{\circ}$ Simpósio de Geologia da Amazônia, SBG (NO), Belém-PA, Resumos Expandidos, CD-ROM.

Geraldes M.C., Van Schmus W.R., Condie K.C., Bell S., Teixeira W., Babinski M. 2001. Proterozoic geologic evolution of the SW part of the Amazonian Craton in Mato Grosso state, Brazil. Precambrian Research, 111:91-128 
Gibbs A.K. and Barron C.N. 1983. The Guiana shield reviewed. Episodes, 2:7-14.

Gioia S.M.C.L. and Pimentel M.M. 2000. The Sm-Nd isotopic method in the geochronology laboratory of the University of Brasília. Anais da Academia Brasileira de Ciências, 72(2):219-245.

Giuliani G. 1987. La cassitérite zonée du gisement de Sokhret Allal (Granite des Zaër; Maroc Central): composition chimique et phases fluides associées. Mineralium Deposita, 22(4):253-261.

Groves D.I. and McCarthy T.S. 1978. Fractional Crystallization and the origin of tin deposits in granitoids. Mineralium Deposita, 13:11-26.

Harrison T.M. 1981. Diffusion of ${ }^{40} \mathrm{Ar}$ in hornblende. Contributions to Mineralogy and Petrology, 78:324-331.

Hasui Y. 1993. Megaestruturação pré-cambriana do território brasileiro baseada em dados geofísicos e geológicos. Revista de Geociências da USP/UNESP, 12(1):7-31.

Hasui Y. e Haralyi N.L.E. 1985. Integração de informações geofísicas e geológicas na definição de estruturas crustais brasileiras. In: Ata do $2^{\circ}$ Simpósio de Geologia do Centro-Oeste, SBG, Goiânia, p. 1-8.

Hasui Y., Haralyi N.L.E., Schobbenhaus C. 1984. Elementos geofísicos e geológicos da região Amazônica: subsídios para o modelo geotectônico. In: Anais do $2^{\circ}$ Simpósio Amazônico, DNPM/CNPq, Manaus, p. 129 141.

Hedenquist J.W. and Lowenstern J.B. 1994.The role of magmas in formation of hydrothermal ore deposits. Nature, 370:519-527.

Hibbard M.J. 1979. Myrmekite as a marker between pre and post aqueous phase saturation in granitic systems. Geological Society of America Bulletin, 90:1047-1062.

Hibbard M.J. 1987. Deformation of incompletely crystallized magma systems: granitic gneisses and their tectonics implications. Journal of Geology, 95:543-561.

Hoffman P.F. 1991. Did the breakout of Laurentia turn Gondwanaland inside-out? Science, 252:1409-1412.

Holmes A. 1946. An estimate of the age of the earth. Nature, 157, p. 680-684.

Houtermans F.G. 1946. The isotope ratios in natural lead and the age of uranium. Naturwissenschaften, v. 33, p. 183-186.

Hughes C.J. 1982. Igneous Petrology. Elsevier Scientific, New York, Developments in Petrology, 7, 551 p.

Irvine T.N. and Baragar W.R. 1971. A guide to the chemical classification of the common igneous rocks. Canadian Journal of Earth Sciences, 8, p. 523-548.

Isotta C.A.L., Carneiro J.M., Kato H.T., Barros R.J.L. 1978. Projeto Província Estanífera de Rondônia: relatório final. MME/DNPM/CPRM, Porto Velho, vol. I, 407 p.

Johnson S.E., Schmidt K.L., Tate M.C. 2002. Ring complexes in Peninsular Ranges Batholitth, Mexico and USA: magma plumbing systems in the middle and upper crust. Lithos, 61:187-208.

Kelly W. e Rye R.O. 1979. Geologic, fluid inclusion, and stable isotope studies of the tin-tungsten deposits of Panasqueira, Portugal. Economic Geology, 74(8):1721-1822.

Keppie J.D., Dostal J., Ortega-Gutiérrez F., Lopez R. 2001. A Grenvillian arc on the margin of Amazonia: evidence from the southern Oaxacan Complex, southern Mexico. Precambrian Research, 112:165-181.

Kerrich R. 1989. Geochemical evidence on the sources of fluids and solutes for shear zone hosted mesothermal Au deposits. In: Bursnall J.T. (eds.), Mineralization and Shear Zones. Geological Association of Canada, Short Course Notes, 6, p. 129-198.

King P.L., Chappell B.W., Allen C.M., White A.J.R. 2001. Are A-type granites the high temperature felsic granites? Evidence from fractionated granites of the Wangrah Suite. Australian Journal of Earth Sciences, 48:501-514.

Kloosterman J.B. 1968. Uma província do tipo nigeriano no sul da Amazônia. Revista de Engenharia, Mineração e Metalurgia. Rio de Janeiro. XLVII 278:59-64 e XLVII 280:167-168.

Kretz R. 1983. Symbols for rock-forming minerals. American Mineralogist, v. 68, p. 277-279.

Kühne R., Wasternack J., Schulze H. 1972. Post-magmatische Metasomatose im Endo-Exokontakt der jüngeren postkinematischen Granite des Erzgebirges. Geologie, 21:494-520.

Landenberger B. and Collins W.J. 1996. Derivation on A-type granites from dehydrated charnockitic lower crust: evidence from the Chaelundi Complex, eastern Australia. Journal of Petrology, 37:145-170.

Le Maitre R.W. 1989. A Classification of Igneous Rocks and Glossary of Terms: Recommendations of the International Union of Geological Sciences Subcommission on the Systematics of igneous rocks. Blackwell, Oxford, 193 p. 
Leal J.W.L., Silva G.H., Santos D.B., Teixeira W., Lima M.I.C., Fernandes C.A.C., Pinto A.C. 1978. Levantamento de Recursos Naturais: Folha SC.20 Porto Velho (I-Geologia). MME/DNPM. Projeto RADAMBRASIL, Rio de Janeiro, v. 16, p. 19-184.

Lee J.K.W., Williams I.S., Ellis D.J. 1997. Pb, U and Th diffusion in natural zircon. Nature, 390:152-162.

Lehmann B. 1990. Metallogeny of tin. In: S. Bhattacharji et al. (eds.). Lecture notes in earth sciences (32). Springer-Verlag. New York, $211 \mathrm{p}$.

Leite Jr. W.B. 2002. A Suíte Intrusiva Santa Clara (RO) e a mineralização primária polimetálica ( $\mathrm{Sn}, \mathrm{W}, \mathrm{Nb}, \mathrm{Ta}$, $\mathrm{Zn}$, $\mathrm{Cu}$ e $\mathrm{Pb}$ ) associada. Tese de Doutoramento. Instituto de Geociências da Universidade de São Paulo (IGUSP), $305 \mathrm{p}$.

Leite Jr. W.B., Payolla B.L., Betttencourt J.S., Tassinari C.C.G. 2001. New K-Ar ages of the primary tin mineralization in the Rondônia Tin Province, Brazil. In: III Simpósio Sul Americano de Geologia Isotópica. Pucon-Chile. SNGM/SGC/Universidade de Chile. CD-ROM, session 5, p. 484-487.

Litherland M., Annels R.N., Appleton J.D., Berrange J.P., Bloomfield. K., Burton C.C., Derbyshire D.P.F., Fletcher C.J.N., Harwkins M.P., Klinck B.A., Mitchel W.I., O’Connor E.A., Pitfield P.E.J., Power G., Webb B.C. 1986. The geology and mineral resources of the Bolivian Precambrian Shield. Keyworth, British Geological Survey, Overseas Memoir 9, 153 p.

Litherland M., Annels R.N., Derbyshire D.P.F., Fletcher C.J.N., Harwkins M.P., Klinck B.A., Mitchel W.I., O’Connor E.A., Pitfield P.E.J., Power G., Webb B.C. 1989. The Proterozoic of eastern Bolivia and its relationship with the Andean mobile belt. Precambrian Research, 43:157-174.

Lobato F.P.N.S., Apeel L.E., Godoy M.C.F.T., Ritter J.E., LASA. 1966. Pesquisa de cassiterita no Território Federal de Rondônia (Relatório Final). MME-DNPM-DFPM. Boletim Nº 125, 209 p.

Maniar P.D. and Piccoli P.M. 1989.Tectonic discrimination of granitoids. Geological Society American Bulletin, 101:635-643.

Manning D.A.C. 1982. An experimental study of the effects of flourine on the crystallization of granites melts. In: A.M. Evans (eds.). Metallization Associated with Acid Magmatism. John Wiley \& Sons, New York, 191203.

McDougall I and Harrison T.M. 1988. Geochronology and Thermochronology by the ${ }^{40} \mathrm{Ar}{ }^{39} \mathrm{Ar}$ Method. Oxford University Press, N.Y., 212 p.

McDougall I. and Harrison T.M. 1999. Geochronology and Thermochronology by the ${ }^{40} \mathrm{Ar}{ }^{39} \mathrm{Ar}$ Method. Oxford University Press, N.Y., 2nd ed., 288 p.

Middelaar W.T. Van and Keith J.D. 1990. Mica chemistry as an indicator of oxygen and halogen fugacities in the Can Tung and other W-related granitoids in the North American Cordillera. In: H.J. Stein and J.L. Hannah (eds.). Ore-bearing granites systems: petrogenesis and mineralizing processes. Geological Society of America, Special Paper, 246, p. 205-220.

Middlemost E.A.K. 1994. Naming materials in magma/igneous rock system. Earth-Science Reviews, 37, 215 224.

Möller A., Mezger K., Schenk V. 1998. Crustal age domains and the evolution of the continental crust in the Mozambique Belt of Tanzania: a combined $\mathrm{Sm}-\mathrm{Nd}, \mathrm{Rb}-\mathrm{Sr}$ and $\mathrm{Pb}-\mathrm{Pb}$ evidence. Journal of Pretology, 39:749-783.

Möller P., Dulski P., Szacki W., Malow G., Riedel E. 1988. Substitution of tin in cassiterite by tantalum, niobium, tungsten, iron and manganese. Geochimica et Cosmochimica Acta, 52:1497-1503.

Montalvão R.M.G. e Bezerra P.E.L. 1980. Geologia e tectônica da Plataforma (Cráton) Amazônica (parte da Amazônia legal brasileira). Revista Brasileira de Geociências, 10:1-27.

Moore F. and Howie R.A. 1979. Geochemistry of some Cornubian cassiterites. Mineral Deposita, 14:103-107.

Murciego A., Garcia Sanches A., Martin Pozas J.M. 1987. Microinclusiones de cassiteritas de distintos tipos de yacimientos del centro-oeste de Espanã. Cuadernos do Laboratorio Xeologico de Laxe, 12:273-88.

Murciego A., Sanchez A.G., Dusausoy Y., Pozas J.M.M., Ruck R. 1997. Geochemistry and EPR of cassiterites from the Iberian Hercynian Massif. Mineralogical Magazine, 61:357-365.

Neiva A.M.R. 1996. Geochemistry of cassiterite and its inclusions and exsolutions products from tin and tungsten deposits in Portugal. The Canadian Mineralogist, 34:745-768.

Ohmoto H. 1986. Stable isotope geochemistry of ore deposits. Valley J.W., Taylor Jr. H.P., O'Neil J.R., (eds.). Reviews in Mineralogy Volume 16: Stable Isotopes in High Temperature Geological Processes. Mineralogical Society of America, p. 491-560. 
Okida R. 2001. Aplicação do sensoreamento remoto e aerogamaespectrometria ao estudo do controle estrutural dos granitos estaníferos de Rondônia. Tese de Doutoramento, Instituto de Geociências, Universidade de São Paulo, São Paulo, 217 p.

Oversby V.M. 1976. Isotopic ages and geochemistry of Archean acid igneous rochs from the Pilbara, wester Australia. Geochimica et Cosmochimica Acta, 40(7):817-829.

Payolla B.L., Bettencourt J. S., Kozuch M., Leite Jr. W.B., Fetter A.H., Van Schmus R. 2002. Geological evolution of the basement rocks in the central-eastern part of the Rondonia Tin Province, SW Amazonian Craton, Brazil: U-Pb and Sm-Nd isotopic constraints. Precambrian Research, 119:141-169.

Pearce J.A., Harris N.B.W., Tindle A.G. 1984. Trace element discrimination diagrams for the tectonic interpretation of granitic rocks. Journal of Petrology, 25:956-983.

Plimer I.R. 1987. Fundamental parameters for the formation of granite-related tin deposits. Geologische Rundschau, 76(1):23-40.

Pollard P.J. and Taylor R.G. 1986. Progressive evolution of alteration and tin mineralization: controls by interstitial permeability and fracture-related tapping of magmatic fluid reservoirs in tin granites. Economic Geology, 81:1795-1800.

Priem H.N.A., Boelrijk N.A.I.M., Hebeda E.H., Verschure R.H., Bom E.H. 1966. Isotopic age of tin granites in Rondônia, N.W. Brazil. Geologie en Mijnbouw, 45:191-192.

Priem H.N.A., Boelrijk N.A.I.M., Hebeda E.H., Verdurmen E.A.Th., Verschure R.H., Bom E.H. 1971. Granitic complexes and associated tin mineralizations of "Grenville" age in Rondônia, western Brazil. Geological Society of America Bulletin, 82:1095-1102.

Priem H.N.A., Bom E.H., Verdurmen E.A.Th., Bettencourt J.S. 1989. Rb-Sr chronology of Precambrian crustal evolution in Rondônia (western margin of the Amazonian craton), Brazil. Journal of South America Earth Science, 2(2):163-170.

Quadros M.L. do E.S. 2007. Geologia e recursos minerais do Estado de Rondônia: Sistema de Informações Geográficas - SIG: Texto Explicativo do Mapa Geológico e de Recursos Minerais do Estado de RondôniaEscala 1:1.000.000. Quadros M.L do E.S. e Rizzoto G.J (org.). Porto Velho: CPRM. 153 p.

Quadros M.L do E.S. 2011. Geologia e recursos minerais da Folha Rio Machadinho (SC.20-X-C): Sistema de Informações Geográficas - SIG: Texto Explicativo dos mapas geológico e de recursos minerais da Folha Rio Machadinho, escala 1:250.000. Quadros M.L do E.S., Palmeira L.C.M, Castro C.C. (eds.). Porto Velho: CPRM. 160 p.: il. color. + DVD-ROM

Queiroz L.A.V. de. 2009. Estudos litogeoquímicos, isotópicos e petrográficos da Suíte Intrusiva Alto Candeias (RO), SW do Cráton Amazônico. Trabalho de monografia. Rio de Janeiro, IG-FGEO-UERJ, 99 p.

Ramsay J. 1980. The crack \pm seal mechanism of rock deformation. Nature, 284:135-139.

Richards J.P. and Noble S.R. 1998. Application of radiogenic isotope systems to the timing and origin of hydrothermal processes. In: J.P. Richards and P.B. Larson (Eds.). Techniques in hydrothermal ore deposits geology. Reviews in Economic Geology, 10:195-233.

Riedel W. 1929. Zur Mechanik Geologischer Brucherscheinungen. Zentral-blatt fur Mineralogie, Geologie und Paleontologie B., p. 354-368.

Rios F.J, Villas R.N., Fuzikawa K., Sial A.N., Mariano G. 1998. Isótopos de oxigênio e temperatura de formação dos veios mineralizados com wolframita da jazida Pedra Preta, sul do Pará. Revista Brasileira de Geociências, 28(3)253-256.

Rizzotto G.J. e Quadros M.L. do E.S. 2003. Geologia da folha Juruena SC.21. In: Simpósio Brasileiro de Geologia do Centro-oeste, 8, Boletim de Resumos. Cuiabá: SBG-Núcleo Centro-Oeste, p. 116-117.

Rizzotto G.J. e Quadros M.L. do E.S. 2005. Geologia do sudoeste do Cráton Amazônico. In: Horbe A.M.C. e Souza V. da S. (coord.). Contribuições a geologia da Amazônia. Belém: SBG-Núcleo Norte, v.4, p. 69-84.

Rizzotto G.J., Quadros M.L.E.S., Scandolara J.E., Silva C.R., Bahia R.B.C. 1995. Posicionamento estratigráfico da sequência metavulcanossedimentar Roosevelt na região limítrofe dos estados de RO-MT. In: SBGUFRGS-CPRM, Simpósio Nacional de Estudos Tectônicos, 5, Gramado, Boletim de Resumos Expandidos, p. 310-312.

Rizzotto G.J., Quadros M.L. do E.S., Silva L.C., Armstrong R., Almeida M. 2002. O Granito Aripuanã: datação U-Pb (SHRIMP) e implicações metalogenéticas. In: SBG, Congresso Brasileiro de Geologia, 41, João Pessoa. Anais, p. 469 
Rizzotto G.J., Quadros M.L. do E.S., Bahia R.B.C., Cordeiro A.V. 2004. Folha SC.20-Porto Velho. In: Schobbenhaus C., Goncalves J.H., Santos J.O.S., Abram M.B., Leão Neto R., Matos G.M.M., Vidotti R.M., Ramos M.A.B., Jesus J.D.A. de (eds.). Carta Geológica do Brasil ao Milionésimo, Sistema de Informações Geográficas. Programa Geologia do Brasil. Brasília: CPRM, 1 CD-Rom.

Rizzotto G.J., Santos J.O.S., Hartmann L.A., Tohve, E., Pimentel M.M., MacNaughton N.J. 2013. The Mesoproterozoic Guaporé suture in the SW Amazonian Craton: Geotectonic implications based on field geology, zircon geochronology and Nd-Sr isotope geochemistry. Journal of South American Earth Sciences, 48:271-295.

Rizzotto G.J., Hartmann L.A., Santos J.O.S., McNaughton N.J. 2014. Tectonic evolution of the southern margin of the Amazonian craton in the late Mesoproterozoic based on field relationships and zircon U-Pb geochronology. Annals of the Brazilian Academy of Sciences, 86(1):57-84.

Roddick J.C. 1983. High precision intercalibration of ${ }^{40} \mathrm{Ar} /{ }^{39} \mathrm{Ar}$ standards. Geochimica et Cosmochimica Acta, 47, p. 887-898.

Rollinson H. 1993. Using geochemical data: evaluation, presentation, interpretation. Longman Scientific \& Technical. John Wiley \& Sons, New York, 352 p.

Romanini S.J. 2000. Geologia e resultados prospectivos das áreas Serra dos Pacaás Novos e Rio CautárioRondônia. Porto Alegre: CPRM (Informe de Recursos Minerais. Série Metais do Grupo da Platina e Associados, 20).

Sadowski G.R. and Bettencourt J.S. 1996. Mesoproterozoic tectonic correlations between eastern Laurentia and the western border of the Amazon Craton. Precambrian Research, 76:213-227.

Samson I.M. 1990. Fluid evolution and mineralization in a subvolcanic granite stock: the Mount Pleasant WMo-Sn deposits, New Brunswick, Canada. Economic Geology, 85:145-163.

Santos J.O.S. 2000. Os terrenos paleoproterozóicos da Província Tapajós e as mineralizações de ouro associadas. Tese de Doutorado em Ciências. Porto Alegre, CPGG-UFRS, 209 p.

Santos J.O.S. 2004. Geotectônica dos escudos das Guianas e Brasil-Central. In: Bizzi L.A., Schobbenhaus C., Vidotti R.M., Gonçalves J.H., (Coord.). Geologia, Tectônica e Recursos Minerais do Brasil. CPRM, Brasília, p. 169-226.

Santos J.O.S., Hartmann L.A., Gaudette E.H.E., Groves D.I., McNaughton N.J. \& Fletcher I.R. 2000. New understanding of the province of the Amazon craton based on integration of field mapping and $\mathrm{U}-\mathrm{Pb}$ and $\mathrm{Sm}$ Nd geochronology. Mineralium Deposita (in press).

Santos J.O.S., Rizzotto G.J., Hartmann L.A. 2001. Ages sedimentary basins related to the Sunsás and Juruena orogenies, southwest Amazon Craton established by zircon U-Pb geochronology. In: Bettencourt J.S., Teixeira W., Pacca I.G., Geraldes M.C., Sparrenberger I. (eds.). Workshop on Geology of The SW Amazonian Craton: State-of-the-Art, São Paulo. São Paulo: Institute of Geosciences. University of São Paulo. Extended Abstracts, p. 114-118.

Santos J.OS., Rizzotto G.J., Easton M.R., Potter P.E., Hartmann L.A., Mcnaughton N.J. 2002. The Sunsás Orogen in Western Amazon Craton, South America and correlation with the Grenville Orogen of Laurentia, based on U-Pb isotopic study of detrital and igneous zircons. Denver: Geological Society of America.

Santos J.O.S., Rizzotto G.J., Chemale F., Hartmann L.A., Quadros M.L. do E.S.; McNaughton N.J. 2003. Three distinctive collisional orogenies in the Southwestern Amazon craton: constraints from U-Pb geochronology. In: South American Symposium on Isotope Geology, 4, 24-27 Aug. 2003, Salvador. Papers, Salvador: CBPM, p. 282-285.

Santos J.O.S, Van Breemen O.B., Groves D.I., Hartmann L.A., Almeida M.E., Mcnaughton N.J., Fletcher, I.R. 2004. Timing and evolution of multiple Paleoproterozoic magmatic arcs in the Tapajós Domain, Amazon Craton: constraints from SHRIMP and TIMS zircon, baddeleyite and titanite U-Pb geochronology. Precambrian Research, 131:73-109.

Santos J.O.S. dos, Hartmann L.A., Faria M.S.G. de, Riker S.R.L., Souza M.M. de, Almeida M.E., McNaughton N.J. 2006. A Compartimentação do Cráton Amazonas em Províncias: Avanços ocorridos no período 20002006. In: Simpósio de Geologia da Amazônia, 9, SBG (NO), Belém, CD-ROM.

Santos J.O.S., Rizzotto G.J., Potter P.E., McNaughton N.J., Matos R.S., Hartmann L.A., Chemale F., Quadros M.L. do E.S. 2008. Age and autochthonous evolution of the Sunsás Orogen in West Amazon Craton based on mapping and U-Pb geochronology. Precambriam Research, 165:120-152. 
Sato K. e Tassinari C.C.G. 1997. Principais eventos de acresção continental no Cráton Amazônico baseados em idade-modelo Sm-Nd, calculada em evoluções de estágio único e estágio duplo. In: Costa M.L. da e Angélica R.S. (Coord.). Contribuições à Geologia da Amazônia. Belém, FINEP/SBG, p. 91-142.

Scandolara J.E. 2006. Geologia e evolução do Terreno Jamari, embasamento da faixa Sunsás/Aguapeí, centroleste de Rondônia, sudoeste do Cráton Amazônico. Tese de Doutoramento, Instituto de Geociências, Universidade de Brasília, $384 \mathrm{p}$.

Scandolara J.E., Rizzotto G.J., Bahia R.B.C., Quadros M.L.E.S, Amorim J.L., Dall'Igna L.G. 1999. Geologia e Recursos Minerais do Estado de Rondônia: texto explicativo e mapa geológico, escala 1:1.000.000. Programa Levantamentos Geológicos do Brasil. CPRM Serviço Geológico do Brasil, Brasília, Brasil.

Scandolara J.E., Rizzotto G.J., Amorim J.L., Quadros M.L.E.S., Bahia R.B.C. 2001. Evolução geológica do segmento sudoeste do Cráton Amazônico - Estado de Rondônia e adjacências. In: Reis N.J. e Monteiro M.A.S. (Coord.). Contribuições à Geologia da Amazônia (Volume 2). Manaus, SBG-Núcleo Norte, 9:251340.

Scandolara J.E., Fuck R.A., Dantas E.L., Souza V.S., 2013a. Geochemistry of Jamari complex, central-eastern Rondônia: Andean type magmatic arc and Paleoproterozoic crustal growth of the southwestern Amazonian Craton, Brazil. Journal of South American Earth Sciences. 46, p. 1-28.

Scandolara J.E., Fuck R.A., Dall'Agnol R., Dantas E.L. 2013b. Geochemistry and origin of the early Mesoproterozoic mangerite-charnockite-rapakivi granite association of the Serra da Providência suite and associated gabros, central-eastern Rondônia, SW Amazonian Craton, Brazil. Journal of South American Earth Sciences, 45, p. 166-193.

Scherba G.N. 1970a. Greisens (part 1). International Geology Review, 12(2):114-255.

Scherba G.N. 1970b. Greisens (part 2). International Geology Review, 12(3):239-255.

Schneider H.J, Dulski P., Luck J., Moller P., Villalpando A. 1978. Correlation of trace element distribution in cassiterites and geotectonic position of their deposits in Bolivia. Mineral. Deposita, 13:119-122.

Schobbenhaus C. e Campos D.A. 1984. A evolução da plataforma sul-americana no Brasil e suas principais concentrações minerais. In: Schobbenhaus C. (Coord.). Geologia do Brasil. Brasília, MME/DNPM, p. 9-53.

Sillitoe R.H., Halls C., Grant J.N. 1975. Porphyry tin deposits in Bolivia. Economic Geology, 70:913-927.

Silva L.C., Armostrong R., Pimentel M.M., Scandolara J., Ramgrab G., Windler W., Angelim L.A., Vasconcelos A.M., Rizzotto G., Quadros M.L., Sander A., Rosa A.L.Z. 2002. Reavaliação da evolução geológica em terrenos pré-cambrianos brasileiros com base em novos dados U-Pb, SHIRIMP, parte III. Províncias Borborema, Mantiqueira meridional e Rio Negro-Juruena. Revista Brasileira de Geociências, 32:529-544.

Smith B., Banks D.A., Yardley B.W.D., Boyce A. 1996. Fluid inclusion and stable isotope constraints on the genesis of the Cligga Head Sn-W deposit, S.W. England. European Journal of Mineralogy, 8:961-974.

Souza E.C., Melo A.F.F., Adamy A., Soeiro R.S., Daleiro V. 1975. Projeto nordeste de Rondônia: relatório final. MME/DNPM/CPRM, Brasília, v.1, 225 p.

Souza V.S. 2003. Evolução magmática e modelo metalogenético do sistema vulcanoplutônico estanífero Bom Futuro (RO). Tese de Doutorado. Instituto de Geociências, Universidade de Brasília, Brasília, 240p.

Souza V.S. e Botelho N.F. 2009. Composição química e isótopos de oxigênio em cassiterita e wolframita nos greisens do albita granito Palanqueta, depósito de estanho de Bom Futuro (RO). Revista Brasileira de Geociências, 39(4): 695-704.

Souza V.S., Botelho N.F., Dantas E.L., Gioia S.M.C.L. 2005. Geoquímica e isótopos de Nd das rochas do Complexo Jamari na área do depósito de Bom Futuro (RO). In: Horbe A.M.C. \& Souza V.S. (Coord.). Contribuições à Geologia da Amazônia, v.4, p. 85-98.

Souza V.S., Teixeira L.M., Dantas E.L. Botelho N.F., Laux J.H. 2006. Idades U-Th-Pb e U-Pb em monazita de ortognaisse do Complexo Jamari, área do depósito de estanho de Bom Futuro (RO). Revista Brasileira de Geociências, 36(1):71-76.

Souza V.S., Nascimento T.M., Wanderley V.J.R. 2010. The ${ }^{40} \mathrm{Ar} /{ }^{39} \mathrm{Ar}$ age of the Igarapé Manteiga W-Sn Deposit, Rondônia Tin Province, Brazil. In: VII South American Symposium on Isotope Geology (SSAGI), Brasília, CD-ROM, p. 261-263.

Sparrenberger I. 2003. Evolução da mineralização primária estanífera associada ao maciço granítico Santa Bárbara, Rondônia. Tese de Doutorado, Instituto de Geociências, Universidade de São Paulo, São Paulo, $252 p$.

Sparrenberger I., Bettencourt J.S., Tosdal R.M., Wooden J.L. 2002. Datações U-Pb convencionais versus 
SHRIMP do maciço estanífero Santa Bárbara, suíte Granitos Últimos de Rondônia, Brasil. Geologia USP, Série Científica, v. 2, p. 79-94.

Stacey J.S. and Kramers JD. 1975. Approximation of terrestrial lead isotope evolution by a two-stage model. Earth Planet. Science Letters, 26:207-221.

Steiger R.H. and Jäger E. 1977. Subcommission on geochronology: Convention on the use of decay constants in geo and cosmo-chronology. Earth and Planetary Science Letters, Volume 36, p. 359-362.

Stemprok M. 1987. Greisenization (a review). Geologische Rundschau, 76(1):169-175.

Streckeisen A.L. 1976. Classification of the common igneous rocks by means of their chemical composition: a provisional attempt. Neues Jahrbuch fur Mineralogie, Monatshefte, 1:1-15.

Suzuoki T. and Epstein J.D. 1976. Hydrogen isotope fractionation betweeen OH-bearing minerals and water. Geochemical et Cosmochemical Acta, 40:1229-1240.

Tassinari C.C.G. 1981. Evolução geotectônica da Província Rio Negro-Juruena na região Amazônica. Dissertação de Mestrado, IG-USP, São Paulo, 2v., 99 p.

Tassinari C.C.G. 1996. O mapa geocronológico do Cráton Amazônico no Brasil: revisão dos dados isotópicos. IG-USP, São Paulo, Tese de Livre Docência, 139 p.

Tassinari C.C.G. and Macambira M.J.B. 1999. Geochronological provinces of the Amazonian Craton. Episodes, 22(3):174-182.

Tassinari C.C.G. e Macambira M.J.B. 2004. A evolução tectônica do Cráton Amazônico. In: Mantesso-Neto V., Bartorelli A., Dal Ré Carneiro C., Brito-Neves B.B. (eds.). Geologia do Continente Sul-Americano: Evolução da obra de Fernando Flávio Marques de Almeida. Beca, São Paulo, 2004. p. 471-485.

Tassinari C.C.G., Siga O.Jr., Teixeira W. 1984. Épocas metalogenéticas relacionadas a granitogênese do Cráton Amazônico. In: XXXII Congreso Brasileiro de Geologia, Anais, 6:2963-2977.

Tassinari C.C.G., Cordani U.G., Nutman A.P., Van Schmus W.R., Bettencourt J.S., Taylor P.N. 1996. Geochronological systematics on basement rocks from the Rio Negro-Juruena Province (Amazonian craton), and tectonic implications. International Geological Review, 38(2):161-175.

Tassinari C.C.G., Bettencourt J.S., Geraldes M.C., Macambira M.J.B., Lafon J.M. 2000. The Amazonian Craton. In: Cordani U.G., Milani E.J., Thomaz Filho A., Campos D.A. (eds.). Tectonic Evolution of South America.

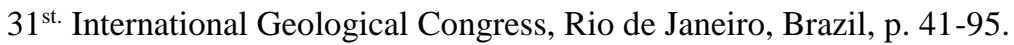

Taylor B.E. 1992. Degassing of $\mathrm{H}_{2} \mathrm{O}$ from rhyolite magma during eruption and shallow intrusion, and the isotopic composition of magmatic water in hydrothermal system. Geological Survey of Japan Report, 279, p. 190-195.

Taylor R.G. 1979. Geology of tin deposits. In: developments in economic geology (11). Elsevier Ed. Amsterdam, $543 \mathrm{p}$.

Taylor Jr. H.P. 1968. The oxygen isotope geochemistry of igneous rock. Contributions to Mineralogy and Petrology, 19:1-71.

Taylor Jr. H.P. 1974. The application of oxygen and hydrogen isotope studies to problems of hydrothermal alteration and ore deposition. Economic Geology, 69:843-883.

Taylor Jr. H.P. 1978. Oxygen and hydrogen isotope studies of plutonic granitic rocks. Earth and Planetary Science Letters, 38:177-210.

Taylor Jr. H.P. 1997. Oxygen and hydrogen isotope relationships in hydrothermal mineral deposits. In: Barnes H.L. (eds.). Geochemistry of Hydrothermal ore deposits. John Wiley \& Sons, New York, $3^{\text {nd }}$, p. 229-302.

Teixeira W., Tassinari C.C.G., Cordani V.G., Kawashita K. 1989. A review of the geochronology of the Amazonian Craton: tectonic implications. Precambrian Research, 42(3-4):213-227.

Teixeira W., Geraldes M.C., Matos R., Ruiz A.M., Saes G., Vargas-Mattos G. 2010. A review of the tectonic evolution of the Sunsás belt, SW Amazonian Craton. Journal of South American Earth Sciences, 29:47-60.

Thompson R.N. 1982. Magmatism of the British Tertiary volcanic province. Scottish Journal of Geology, 18:49107.

Tohver E., Van der Pluijm B., Scandolara J., Rizzotto, G. 2001. A reassessment of the tectonics and paleogeography of the Grenville-aged Sunsás-Aguapeí Belt, SW Amazon Craton: new paleomagnetic and ${ }_{40} \mathrm{Ar} /{ }^{40} \mathrm{Ar}$ data. In: Bettencourt J.S., Teixeira W., Pacca I.G., Geraldes M.C., Sparrenberger I. (eds.). Workshop Geology of the SW Amazonian Craton: State-of-the-Art. Institute of Geosciences - University of São Paulo - Brazil. IGCP Project 426, p. 151-154. 
Tohver E., Van der Pluijm B., Van der Voo, R. Rizzotto G., Scandolara, J.E 2002. Paleogeography of the Amazon craton at $1.2 \mathrm{Ga}$ : early Grenvillian collision with the Liano segment of Laurentia. Earth and Planetary Science Letters, 6188:1-16.

Tohver E., Van der Pluijm B.A., Mezger K., Scandolara J.E., Essene E.J. 2005. Two stage tectonic history of the SW Amazon craton in the late Mesoproterozoic: identifying a cryptic suture zone. Precambrian Research, 137:35-59.

Tosdal R.M., Wooden J.L., Bouse R.M. 1999. Pb isotopes, ore deposits and metallogenic terranes. In: Lambert D.D. and Ruiz J. (eds.). Application of radiogenic isotopes to ore deposit research and exploration, Reviews. Economic Geology, 12:1-28

Urung R. 1996. The assembly of Gondwanaland. Episodes, 19:11-20.

Van Schmus W.R. 2001. Late Paleoproterozoic to early Neoproterozoic orogenesis in southern Laurentia and possible correlations with SW Amazonia. In: Bettencourt J.S., Teixeira W., Pacca I.G., Geraldes M.C., Sparrenberger I. (eds.). Workshop Geology of the SW Amazonian Craton: State-of-the-Art. Institute of Geosciences - University of São Paulo - Brazil. IGCP Project 426, p. 100-104.

Veneziani P., Okida R., Bettencourt J.S. 2001. Movimentos tectônicos ao longo das principais linhas de fraquezas crustais na Província Estanífera de Rondônia (PER) e sua implicação no alojamento dos maciços graníticos. In: Bettencourt J.S., Teixeira W., Pacca I.G., Geraldes M.C., Sparrenberger I. (eds.). Workshop Geology of the SW Amazonian Craton: State-of-the-Art. Institute of Geosciences - University of São Paulo Brazil. IGCP Project 426, p. 105-109.

Viglino J.A., Harmon R.S., Borthwick J., Nehring N.L., Motyka R.J., White L.D., Jonston D.A. 1985. Stableisotope evidence for a magmatic component in fumarole condensates from Augustine Volcano, Cook Inlet, Alaska, U.S.A Geochemistry Geology, 49:141-157.

Weil A.B., Van der Voo R., Niocaill C.M., Meert J.G. 1998. The Proterozoic supercontinent Rodinia: paleomagnetically derived reconstructions for 1100 to 800 Ma. Precambrian Research, 154:13-24.

Whalen J.B., Currie K.L., Chappell B.W. 1987. A-type granites: geochemical characteristics, discrimination and petrogenesis. Contributions to Mineralogy and Petrology, 95:407-419.

Wood D.A., Joron J.-L. and Treuil M. 1979. A reappraisal of the use of trace elements to classify and discriminate between magma series erupted in different tectonic settings. Earth and Planetary Science Letters, 45, p. 326-36. 1979.

Xavier R.P. 1991. The role of microstructural and fluid processes in the genesis of gold-bearing shear zones: Fazenda Maria Preta mine, Rio Itapicuru greenstone belt, Bahia, Brazil. PhD Thesis, Southampton University, $241 \mathrm{p}$.

Zartman R.E. and Doe B.R. 1981. Plumbo tectonics - The model. Tectonophysics, 75:135 -162.

Zhang L.G., Liu J.X., Chen Z.S., Zhou H.B. 1994. Experimental investigations of oxigen isotope fractionation in cassiterite and wolframite. Economic Geology, 89:150-157.

Zheng, Y.F. 1992. Oxigen isotope fractionation in wolframite. European Journal of Mineralogy, 4:1331-1335. 
Metalogênese do Depósito de Estanho Liberdade, Campo Novo de Rondônia - RO

Paulo Sérgio Mendes dos Santos Júnior

\section{ANEXOS}




\section{ANEXO I - PONTOS VISITADOS}

\begin{tabular}{|c|c|c|c|c|}
\hline PONTO & TOPONIMIA & LAT & LONG & DESCRIÇÃO \\
\hline CNRO-001 & Mina Liberdade & $-10,6387$ & $-63,6720$ & Cava do Paulo Amanso, disposta segundo orientação N30W. \\
\hline CNRO-001A & Cava do Paulo Amanso & $-10,6384$ & $-63,6718$ & Granito greisenizado com veios mineralizados. \\
\hline CNRO-001B & Cava do Paulo Amanso & $-10,6386$ & $-63,6719$ & Granito encaixante levemente greisenizado. \\
\hline CNRO-001C & Cava do Paulo Amanso & $-10,6389$ & $-63,6720$ & Quartzo orientado devido ao fluxo hidrotermal. \\
\hline CNRO-002A & Morrote & $-10,6328$ & $-63,6749$ & Dique de um granito mais fino. \\
\hline CNRO-002B & Morrote & $-10,6333$ & $-63,6736$ & Dique de um granito mais fino. \\
\hline CNRO-002C & Morrote & $-10,6332$ & $-63,6732$ & Granito levemente greisenizado. \\
\hline CNRO-003 & Planta da Mina & $-10,6433$ & $-63,6698$ & Amostras de minério em veios de quartzo. \\
\hline CNRO-004 & Afloramento em viscinal & $-10,6653$ & $-63,6669$ & Granito da Suíte Intrusiva Alto Candeias \\
\hline CNRO-005 & Garimpo & $-10,6205$ & $-63,6383$ & Garimpo de Cassiterita (Estanho). \\
\hline CNRO-006 & Alforamento ao lado de Garimpo & $-10,6204$ & $-63,6348$ & Contato entre granito grosso e granito fino. \\
\hline CNRO-007 & Blocos próximo a Garimpo & $-10,6232$ & $-63,6313$ & Contato entre granito grosso e granito fino. \\
\hline CNRO-008 & Garimpo & $-10,6237$ & $-63,6300$ & Garimpo ativo de Cassiterita (Estanho). \\
\hline P-001 & Campo Novo & $-10,5710$ & $-63,6183$ & Sede Municipal. \\
\hline P-002 & Mina Liberdade & $-10,6430$ & $-63,6741$ & Buracão (Cava 2). \\
\hline P-003 & Cava do Paulo Amanso & $-10,6391$ & $-63,6724$ & Cava do Paulo Amanso, disposta segundo orientação N30W. \\
\hline P-004 & Falha & $-10,6301$ & $-63,6751$ & Serra do Arsênio. \\
\hline P-005 & Garimpo & $-10,6146$ & $-63,6784$ & Garimpo Inativo. \\
\hline P-006 & Garimpo & $-10,6143$ & $-63,6782$ & Fazenda do Prego (Garimpo Inativo). \\
\hline P-007 & Garimpo & $-10,6139$ & $-63,6782$ & Fazenda do Prego (Garimpo Inativo). \\
\hline P-008 & Garimpo & $-10,6145$ & $-63,6785$ & $\begin{array}{c}\text { Fazenda do Prego (Garimpo Inativo). Ocorrência de Wolframita associada a } \\
\text { Cassiterita. }\end{array}$ \\
\hline P-009 & Garimpo & $-10,6146$ & $-63,6478$ & Fazenda do Vito (Garimpo Inativo). \\
\hline P-010 & Garimpo & $-10,6469$ & $-63,6766$ & Garimpo Inativo. \\
\hline P-011 & Garimpo & $-10,6144$ & $-63,6785$ & $\begin{array}{c}\text { Fazenda do Prego (Garimpo Inativo). Ocorrência de Wolframita associada a } \\
\text { Cassiterita. }\end{array}$ \\
\hline P-012 & Garimpo & $-10,6241$ & $-63,6304$ & Garimpo Inativo. \\
\hline P-013 & Garimpo & $-10,6493$ & $-63,6791$ & Garimpo Inativo. \\
\hline
\end{tabular}


Metalogênese do Depósito de Estanho Liberdade, Campo Novo de Rondônia - RO

Paulo Sérgio Mendes dos Santos Júnior

\section{ANEXO II - TABELA DE ESTUTURAS MEDIDAS}

\begin{tabular}{cccccc}
\hline \multicolumn{2}{c}{ CAVA DO PAULO AMANSO } & \multicolumn{3}{c}{ BURAÇÃO (CAVA 2) } \\
\hline Mergulho & $\begin{array}{c}\text { Ângulo de } \\
\text { mergulho }\end{array}$ & $\begin{array}{c}\text { Direção } \\
\text { (Strike })\end{array}$ & Mergulho & $\begin{array}{c}\text { Ângulo de } \\
\text { Mergulho }\end{array}$ & $\begin{array}{c}\text { Direção } \\
\text { (Strike) }\end{array}$ \\
\hline 250 & 25 & 340 & 210 & 25 & 300 \\
248 & 23 & 338 & 212 & 27 & 302 \\
250 & 19 & 340 & 210 & 24 & 300 \\
245 & 27 & 335 & 215 & 25 & 305 \\
256 & 25 & 346 & 212 & 25 & 302 \\
240 & 20 & 330 & 214 & 27 & 304 \\
248 & 25 & 338 & 210 & 25 & 300 \\
246 & 23 & 336 & 218 & 23 & 308 \\
245 & 25 & 335 & 215 & 25 & 305 \\
252 & 27 & 342 & 213 & 27 & 303 \\
247 & 24 & 337 & 201 & 16 & 291 \\
245 & 24 & 335 & 210 & 19 & 300 \\
242 & 25 & 332 & 200 & 16 & 290 \\
252 & 28 & 342 & 200 & 20 & 290 \\
246 & 25 & 336 & 118 & 76 & 208 \\
245 & 25 & 335 & & & \\
245 & 27 & 335 & & & \\
250 & 25 & 340 & & & \\
243 & 20 & 333 & & & \\
245 & 25 & 335 & & & \\
240 & 24 & 330 & & & \\
250 & 28 & 340 & & & \\
\hline
\end{tabular}




\section{ANEXO III - TABELA DE ANÁLISE DE QUÍMICA MINERAL DA CASSITERITA DOS VEIOS E DO GREISEN}

Tabela de Química Mineral dos Veios

\begin{tabular}{|c|c|c|c|c|c|c|c|}
\hline Amostras & $\mathrm{SiO}_{2}$ & $\mathrm{WO}_{3}$ & $\mathrm{FeO}$ & $\mathrm{TiO}_{2}$ & $\mathrm{Nb}_{2} \mathrm{O}_{5}$ & $\mathrm{SnO}_{2}$ & TOTAL \\
\hline CNRO 3B & 0,0430 & 0,0000 & 0,0000 & 0,2400 & 0,0000 & 99,4930 & 99,7760 \\
\hline CNRO 3B & 0,0170 & 0,0000 & 0,0490 & 0,2160 & 0,0230 & 99,4340 & 99,7390 \\
\hline CNRO 3B & 0,0230 & 0,0000 & 0,0250 & 0,2340 & 0,0000 & 99,1690 & 99,4510 \\
\hline CNRO 3B & 0,0310 & 0,0000 & 0,0800 & 0,1620 & 0,0000 & 99,1910 & 99,4640 \\
\hline CNRO 3B & 0,0000 & 0,0000 & 0,0490 & 0,3210 & 0,0230 & 99,4150 & 99,8080 \\
\hline CNRO 3B & 0,0260 & 0,0000 & 0,0430 & 0,2440 & 0,1170 & 99,2220 & 99,6520 \\
\hline CNR 2 & 0,0430 & 0,0090 & 0,0010 & 0,1960 & 0,0000 & 99,3750 & 99,6240 \\
\hline CNR 2 & 0,0240 & 0,0380 & 0,0310 & 0,1980 & 0,2810 & 98,5420 & 99,1140 \\
\hline CNR 2 & 0,0000 & 0,0000 & 0,0000 & 0,1910 & 0,0000 & 98,8680 & 99,0590 \\
\hline CNR 2 & 0,0050 & 0,0000 & 0,0000 & 0,0810 & 0,1640 & 99,6200 & 99,8700 \\
\hline CNRO 3B II & 0,0000 & 0,0000 & 0,0270 & 0,3100 & 0,1170 & 99,6400 & 100,0940 \\
\hline CNRO 3B II & 0,0300 & 0,0100 & 0,0900 & 0,2840 & 0,2570 & 98,9740 & 99,6450 \\
\hline CNRO 3B II & 0,0330 & 0,0000 & 0,0270 & 0,2160 & 0,0700 & 99,4240 & 99,7700 \\
\hline CNRO 3B II & 0,0380 & 0,0000 & 0,0410 & 0,1560 & 0,1170 & 99,3000 & 99,6520 \\
\hline CNRO 3B II & 0,0320 & 0,0000 & 0,0040 & 0,3670 & 0,0230 & 98,6740 & 99,1000 \\
\hline CNRO 3B II & 0,0430 & 0,0000 & 0,0530 & 0,3850 & 0,0000 & 98,8530 & 99,3340 \\
\hline CNRO 3B II & 0,0070 & 0,0000 & 0,0190 & 0,1720 & 0,0930 & 99,0590 & 99,3500 \\
\hline CNRO 3B II & 0,0150 & 0,0000 & 0,0300 & 0,3220 & 0,0000 & 98,7690 & 99,1360 \\
\hline CNRO 3B II & 0,0140 & 0,0000 & 0,0300 & 0,2770 & 0,0000 & 99,4220 & 99,7430 \\
\hline CNRO 3B II & 0,0300 & 0,0000 & 0,0430 & 0,2360 & 0,0470 & 99,2080 & 99,5640 \\
\hline CNRO 3B II & 0,0030 & 0,0000 & 0,0030 & 0,2300 & 0,2570 & 99,3910 & 99,8840 \\
\hline CNRO 3B II & 0,0320 & 0,0000 & 0,0000 & 0,2020 & 0,0470 & 99,7260 & 100,0070 \\
\hline Min 01 & 0,0010 & 0,0190 & 0,0340 & 0,4890 & 0,0700 & 98,6150 & 99,2280 \\
\hline Min 01 & 0,0310 & 0,0000 & 0,0000 & 0,2430 & 0,3510 & 98,9540 & 99,5790 \\
\hline Min 01 & 0,0090 & 0,0000 & 0,0040 & 0,1970 & 0,1870 & 99,1100 & 99,5070 \\
\hline Min 01 & 0,0000 & 0,0000 & 0,0000 & 0,0890 & 0,0000 & 99,4920 & 99,5810 \\
\hline Min 01 & 0,0390 & 0,0000 & 0,0000 & 0,2850 & 0,0000 & 99,3130 & 99,6370 \\
\hline Min 01 & 0,0000 & 0,0200 & 0,0000 & 0,3010 & 0,0000 & 99,0730 & 99,3940 \\
\hline Min 01 & 0,0480 & 0,0000 & 0,0240 & 0,2440 & 0,2810 & 99,1120 & 99,7090 \\
\hline Min 01 & 0,0090 & 0,0000 & 0,0250 & 0,2680 & 0,2570 & 98,9830 & 99,5420 \\
\hline Min 01 & 0,0070 & 0,0000 & 0,0840 & 0,2870 & 0,1170 & 99,0910 & 99,5860 \\
\hline Min 01 & 0,0140 & 0,0000 & 0,0000 & 0,1280 & 0,1640 & 99,3760 & 99,6820 \\
\hline Min 01 & 0,0320 & 0,0000 & 0,0120 & 0,1140 & 0,0000 & 99,2140 & 99,3720 \\
\hline Min 01 & 0,0000 & 0,0000 & 0,0280 & 0,1420 & 0,1400 & 99,5530 & 99,8630 \\
\hline Min 01 & 0,0360 & 0,0000 & 0,0150 & 0,2280 & 0,0000 & 98,8570 & 99,1360 \\
\hline Min 01 & 0,0286 & 0,0000 & 0,0810 & 0,2552 & 0,0000 & 98,8172 & 99,1820 \\
\hline Min 01 & 0,0056 & 0,0000 & 0,0280 & 0,2560 & 0,0684 & 99,4060 & 99,7640 \\
\hline Min 01 & 0,3218 & 0,0000 & 0,0810 & 0,0013 & 0,0000 & 99,0490 & 99,4530 \\
\hline Min 01 & 0,0270 & 0,0000 & 0,0000 & 0,1090 & 0,0000 & 99,7850 & 99,9210 \\
\hline Min 01 & 0,0430 & 0,0000 & 0,0330 & 0,0740 & 0,0230 & 99,4330 & 99,6060 \\
\hline Min 01 & 0,0420 & 0,0000 & 0,0000 & 0,2600 & 0,3510 & 99,1020 & 99,7550 \\
\hline
\end{tabular}




\begin{tabular}{|c|c|c|c|c|c|c|c|}
\hline \multicolumn{8}{|c|}{ Fórmula estrutural na base de 2 oxig. } \\
\hline Amostras & $\mathbf{S i}$ & $\mathbf{W}$ & $\mathrm{Fe}$ & $\mathbf{T i}$ & Nb & Sn & Total \\
\hline CNRO 3B & 0,001078 & 0,000000 & 0,000000 & 0,004526 & 0,000000 & 0,994396 & 1,000000 \\
\hline CNRO 3B & 0,000427 & 0,000000 & 0,001028 & 0,004077 & 0,000261 & 0,994656 & 1,000449 \\
\hline CNRO 3B & 0,000579 & 0,000000 & 0,000526 & 0,004429 & 0,000000 & 0,994729 & 1,000263 \\
\hline CNRO 3B & 0,000780 & 0,000000 & 0,001684 & 0,003067 & 0,000000 & 0,995310 & 1,000842 \\
\hline CNRO 3B & 0,000000 & 0,000000 & 0,001027 & 0,006051 & 0,000261 & 0,993110 & 1,000448 \\
\hline CNRO 3B & 0,000652 & 0,000000 & 0,000902 & 0,004606 & 0,001327 & 0,992631 & 1,000119 \\
\hline CNR 2 & 0,001080 & 0,000059 & 0,000021 & 0,003704 & 0,000000 & 0,995118 & 0,999981 \\
\hline CNR 2 & 0,000605 & 0,000248 & 0,000654 & 0,003757 & 0,003204 & 0,990933 & 0,999402 \\
\hline CNR 2 & 0,000000 & 0,000000 & 0,000000 & 0,003632 & 0,000000 & 0,996368 & 1,000000 \\
\hline CNR 2 & 0,000125 & 0,000000 & 0,000000 & 0,001528 & 0,001859 & 0,996022 & 0,999535 \\
\hline CNRO 3B II & 0,000000 & 0,000000 & 0,000564 & 0,005825 & 0,001321 & 0,992241 & 0,999952 \\
\hline CNRO 3B II & 0,000752 & 0,000065 & 0,001887 & 0,005356 & 0,002913 & 0,989210 & 1,000183 \\
\hline CNRO 3B II & 0,000827 & 0,000000 & 0,000566 & 0,004074 & 0,000793 & 0,993823 & 1,000085 \\
\hline CNRO 3B II & 0,000954 & 0,000000 & 0,000861 & 0,002947 & 0,001328 & 0,994009 & 1,000098 \\
\hline CNRO 3B II & 0,000807 & 0,000000 & 0,000084 & 0,006961 & 0,000262 & 0,991862 & 0,999977 \\
\hline CNRO 3B II & 0,001081 & 0,000000 & 0,001115 & 0,007284 & 0,000000 & 0,991078 & 1,000557 \\
\hline CNRO 3B II & 0,000176 & 0,000000 & 0,000400 & 0,003260 & 0,001059 & 0,995039 & 0,999935 \\
\hline CNRO 3B II & 0,000378 & 0,000000 & 0,000633 & 0,006110 & 0,000000 & 0,993195 & 1,000316 \\
\hline CNRO 3B II & 0,000351 & 0,000000 & 0,000629 & 0,005226 & 0,000000 & 0,994108 & 1,000315 \\
\hline CNRO 3B II & 0,000754 & 0,000000 & 0,000903 & 0,004461 & 0,000534 & 0,993667 & 1,000318 \\
\hline CNRO 3B II & 0,000075 & 0,000000 & 0,000063 & 0,004331 & 0,002908 & 0,991926 & 0,999304 \\
\hline CNRO 3B II & 0,000801 & 0,000000 & 0,000000 & 0,003802 & 0,000532 & 0,994733 & 0,999867 \\
\hline Min 01 & 0,000025 & 0,000124 & 0,000715 & 0,009256 & 0,000796 & 0,989180 & 1,000097 \\
\hline Min 01 & 0,000778 & 0,000000 & 0,000000 & 0,004586 & 0,003981 & 0,989660 & 0,999005 \\
\hline Min 01 & 0,000226 & 0,000000 & 0,000084 & 0,003726 & 0,002125 & 0,993349 & 0,999511 \\
\hline Min 01 & 0,000000 & 0,000000 & 0,000000 & 0,001685 & 0,000000 & 0,998315 & 1,000000 \\
\hline Min 01 & 0,000979 & 0,000000 & 0,000000 & 0,005381 & 0,000000 & 0,993640 & 1,000000 \\
\hline Min 01 & 0,000000 & 0,000130 & 0,000000 & 0,005699 & 0,000000 & 0,994105 & 0,999935 \\
\hline Min 01 & 0,001203 & 0,000000 & 0,000503 & 0,004599 & 0,003183 & 0,989969 & 0,999456 \\
\hline Min 01 & 0,000226 & 0,000000 & 0,000525 & 0,005062 & 0,002917 & 0,990803 & 0,999533 \\
\hline Min 01 & 0,000176 & 0,000000 & 0,001764 & 0,005421 & 0,001328 & 0,991861 & 1,000550 \\
\hline Min 01 & 0,000352 & 0,000000 & 0,000000 & 0,002418 & 0,001862 & 0,994903 & 0,999535 \\
\hline Min 01 & 0,000807 & 0,000000 & 0,000253 & 0,002162 & 0,000000 & 0,996905 & 1,000126 \\
\hline Min 01 & 0,000000 & 0,000000 & 0,000587 & 0,002678 & 0,001587 & 0,995045 & 0,999897 \\
\hline Min 01 & 0,000908 & 0,000000 & 0,000317 & 0,004329 & 0,000000 & 0,994605 & 1,000158 \\
\hline Min 01 & 0,000722 & 0,000000 & 0,001710 & 0,004845 & 0,000000 & 0,994299 & 1,000855 \\
\hline Min 01 & 0,000140 & 0,000000 & 0,000587 & 0,004830 & 0,000776 & 0,993807 & 1,000100 \\
\hline Min 01 & 0,008075 & 0,000000 & 0,001714 & 0,000024 & 0,000000 & 0,999119 & 1,000857 \\
\hline Min 01 & 0,000677 & 0,000000 & 0,000000 & 0,002056 & 0,000000 & 0,997268 & 1,000000 \\
\hline Min 01 & 0,001081 & 0,000000 & 0,000694 & 0,001400 & 0,000261 & 0,996845 & 1,000282 \\
\hline Min 01 & 0,001051 & 0,000000 & 0,000000 & 0,004897 & 0,003972 & 0,989086 & 0,999007 \\
\hline
\end{tabular}


Tabela de Química Mineral do Greisen

\begin{tabular}{ccccccccc}
\hline Amostras & $\mathbf{W O}_{3}$ & $\mathbf{S i O}_{2}$ & $\mathbf{A l 2 O 3}$ & $\mathbf{F e O}$ & $\mathbf{T i O}_{2}$ & $\mathbf{N b}_{2} \mathbf{O}_{5}$ & $\mathbf{S n O}_{2}$ & TOTAL \\
\hline CNR 3 & 0,0000 & 0,0050 & 0,0000 & 0,0600 & 0,1580 & 0,3770 & 98,6400 & 99,2400 \\
CNR 3 & 0,0000 & 0,0450 & 0,0000 & 0,0000 & 0,1890 & 0,0710 & 98,9670 & 99,2720 \\
CNR 3 & 0,0280 & 0,0170 & 0,0000 & 0,0520 & 0,2790 & 0,0000 & 98,3660 & 98,7420 \\
\hline Min 02 & 0,0000 & 0,0000 & 0,0160 & 0,0000 & 0,0890 & 0,0000 & 99,6960 & 99,8010 \\
Min 02 & 0,0000 & 0,0220 & 0,0000 & 0,0310 & 0,1940 & 0,0000 & 98,7280 & 98,9750 \\
Min 02 & 0,0000 & 0,0040 & 0,0130 & 0,0410 & 0,1800 & 0,0900 & 99,3880 & 99,8420 \\
Min 02 & 0,0000 & 0,0160 & 0,0000 & 0,0540 & 0,1950 & 0,0930 & 98,6750 & 99,0330 \\
Min 02 & 0,1210 & 0,0100 & 0,0000 & 0,0000 & 0,1670 & 0,0000 & 98,0000 & 98,6980 \\
Min 02 & 0,0000 & 0,0150 & 0,0130 & 0,0000 & 0,1780 & 0,0850 & 99,4330 & 99,7780 \\
Min 02 & 0,0000 & 0,0270 & 0,0000 & 0,0000 & 0,1760 & 0,0870 & 99,3380 & 99,6800 \\
Min 02 & 0,0000 & 0,0130 & 0,0000 & 0,0320 & 0,2170 & 0,0000 & 98,4300 & 98,6920 \\
Min 02 & 0,0000 & 0,0230 & 0,0000 & 0,0910 & 0,1620 & 0,3470 & 98,2610 & 98,8840 \\
Min 02 & 0,0000 & 0,1000 & 0,0280 & 0,1480 & 0,2240 & 0,2550 & 95,8310 & 96,5860 \\
\hline
\end{tabular}

Fórmula estrutural na base de 2 oxig.

\begin{tabular}{ccccccccc}
\hline Amostras & W & Si & Al & Fe & Ti & Nb & Sn & Total \\
\hline CNR 3 & 0,000000 & 0,000126 & 0,000000 & 0,001264 & 0,002995 & 0,004294 & 0,990879 & 0,999559 \\
CNR 3 & 0,000000 & 0,001134 & 0,000000 & 0,000000 & 0,003583 & 0,000809 & 0,994272 & 0,999798 \\
CNR 3 & 0,000184 & 0,000431 & 0,000000 & 0,001102 & 0,005317 & 0,000000 & 0,993426 & 1,000459 \\
\hline Min 02 & 0,000000 & 0,000000 & 0,000456 & 0,000000 & 0,001681 & 0,000000 & 0,997977 & 1,000114 \\
Min 02 & 0,000000 & 0,000556 & 0,000000 & 0,000656 & 0,003691 & 0,000000 & 0,995425 & 1,000328 \\
Min 02 & 0,000000 & 0,000100 & 0,000370 & 0,000860 & 0,003399 & 0,001020 & 0,993503 & 1,000267 \\
Min 02 & 0,000000 & 0,000404 & 0,000000 & 0,001141 & 0,003707 & 0,001062 & 0,993991 & 1,000305 \\
Min 02 & 0,000799 & 0,000255 & 0,000000 & 0,000000 & 0,003201 & 0,000000 & 0,995346 & 0,999601 \\
Min 02 & 0,000000 & 0,000376 & 0,000370 & 0,000000 & 0,003360 & 0,000964 & 0,994780 & 0,999851 \\
Min 02 & 0,000000 & 0,000678 & 0,000000 & 0,000000 & 0,003326 & 0,000988 & 0,994761 & 0,999753 \\
Min 02 & 0,000000 & 0,000330 & 0,000000 & 0,000679 & 0,004140 & 0,000000 & 0,995191 & 1,000339 \\
Min 02 & 0,000000 & 0,000581 & 0,000000 & 0,001924 & 0,003081 & 0,003966 & 0,990418 & 0,999971 \\
Min 02 & 0,000000 & 0,002584 & 0,000820 & 0,003198 & 0,004354 & 0,002979 & 0,987125 & 1,001059 \\
\hline
\end{tabular}

